\title{
PROTECTION OF PRIVACY IN MALAYSIA: A LAW FOR THE FUTURE
}

\author{
BY \\ ZURYATI MOHAMED YUSOFF \\ A thesis \\ submitted to the Victoria University of Wellington \\ in fulfilment of the requirements for the degree of \\ Doctor of Philosophy
}

Victoria University of Wellington

2014 


\begin{abstract}
In Malaysia, the rights and liberties of the individual are recognised in the Federal Constitution of Malaysia. However, the right to privacy does not have the express constitutional recognition enjoyed by other rights such as the right to life and liberty and freedom of expression. This thesis identifies gaps in the protection of privacy interests in the current legal framework.
\end{abstract}

There is no self-standing law on privacy in Malaysia, though there are several laws which provide limited rights to privacy such as the laws on data protection and criminal law. The existing laws are inadequate to protect private information and to protect against the intrusion of privacy. The importation of foreign principles through the reception of English Common Law offers only limited protection. Malaysia should, therefore, have a specific law to protect privacy.

With a view to attaining that goal for Malaysia, this thesis undertakes a comparative analysis of two different experiences of the development of the law of privacy. They are the privacy law in England, which is largely based on the law of breach of confidence, and the privacy law in New Zealand, which has a distinct privacy tort recognised in its case law. The conclusion is that those countries' experience can inform developments in Malaysia, and that the best way for Malaysia to develop its law now is by the enactment of a specific Privacy Act. 


\section{ACKNOWLEDGMENTS}

In the name of Allah, Most Gracious, Most Merciful. All praise to Allah for His love and blessings.

I take this opportunity to thank my supervisors, Associate Professor Dr Nicole Moreham and Professor Tony Angelo for their valuable guidance and advice, their utmost dedicated supervision throughout my studies. I am indebted to them for their source of motivation and continuous support.

My special thanks and appreciation to my sponsors: the Government of Malaysia and Universiti Utara Malaysia for all the financial support throughout the duration of my studies. I am grateful to the Law Faculty and the Faculty of Graduate Research, Victoria University of Wellington for providing all the facilities and friendly working environment.

I am very grateful to my loving husband, Ahmad Dasuki for all his support, sacrifices and love during my research and writing, and to my children, Isyraf, Wafi, Amsyar and Ajdaa for their endless love and patience for my absence during the toughest time while I was working on this thesis.

This thesis is especially dedicated to my late mother, Hjh Azizah whose presence I shall always miss, and to my late father, $\mathrm{Hj}$ Mohamed Yusoff who passed away while I was in the midst of completing the thesis. I thank my mother in law Hjh Natjah, families and friends whose prayers and moral support always keep me strong to complete this research. 


\section{TABLE OF CONTENTS}

\section{PART I: CONTEXT}

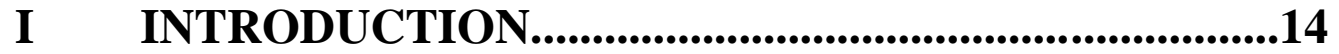

II PRIVACY FROM DIFFERENT PERSPECTIVES......25

PART II: CURRENT PROTECTIONS IN MALAYSIA

III PROTECTION OF PRIVACY INTERESTS IN MALAYSIA.............................................66

IV A COMPARATIVE EXAMINATION OF STATUTORY PROTECTION OF PRIVACY IN MALAYSIA.........................................112

PART III: COMPARATIVE MODELS

$V$ PROTECTION OF PRIVACY INTERESTS IN ENGLISH LAW .............................................................162

VI PROTECTION OF PRIVACY INTERESTS IN NEW ZEALAND.

PART IV: PROPOSAL

VII A PRIVACY LAW FOR MALAYSIA...........................265

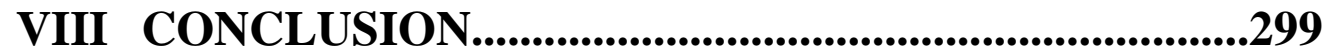




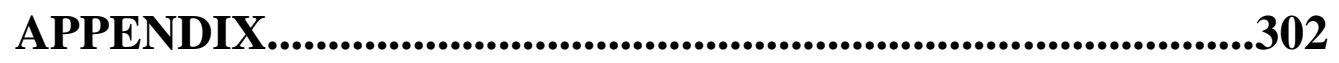

BIBLIOGRAPHY .......................................................................310 


\section{FULL TABLE OF CONTENTS}

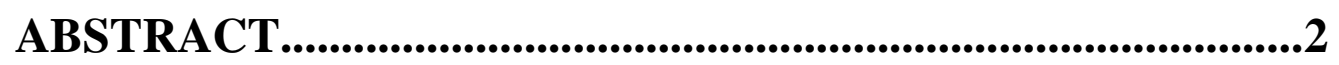

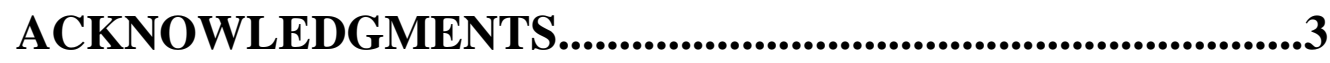

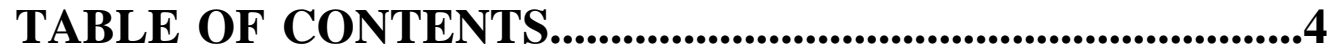

FULL TABLE OF CONTENTS.................................................6

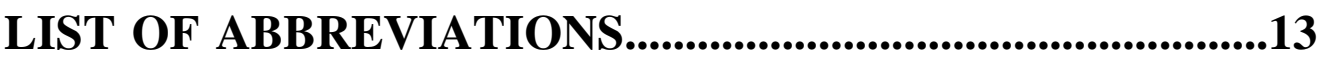

\section{PART I: CONTEXT}

\section{CHAPTER ONE}

INTRODUCTION...............................................................................................14

I OVERVIEW ...........................................................................14

II THE PROBLEM...........................................................................

III THE SCOPE OF RESEARCH AND AIMS OF STUDY .................18

IV THE STRUCTURE OF STUDY .....................................................21

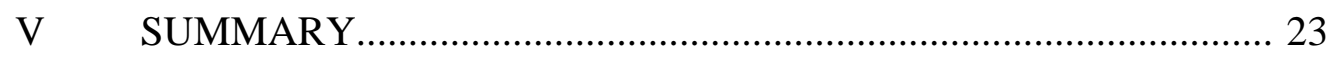

\section{CHAPTER TWO}

PRIVACY FROM DIFFERENT PERSPECTIVES.....................25

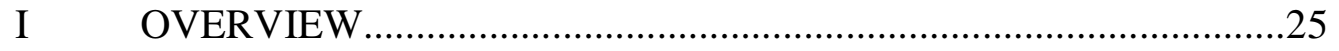

II THE NOTION OF PRIVACY AND ITS IMPORTANCE.................26

III WESTERN CONCEPTION OF PRIVACY.......................................31

A Support for the Control Definition.............................................35

B Criticisms of Control Definition of Privacy...........................39

C Privacy as a State or Condition...............................................4

D Inaccessibility............................................ 45

E Elements of Accessibility ....................................46 
F Intrusion ....................................................

IV PRIVACY AND PRIVATE MATTERS IN ISLAM .......................52

V PRIVACY FROM A MALAYSIAN PERSPECTIVE......................60

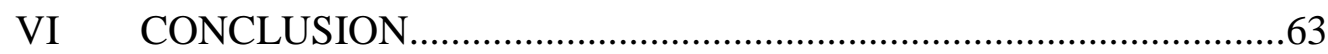

PART II: CURRENT PROTECTIONS IN MALAYSIA

\section{CHAPTER THREE}

PROTECTION OF PRIVACY INTERESTS IN

MALAYSIA....................................................66

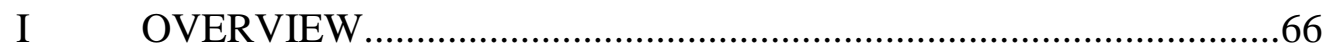

II APPLICABILITY OF ENGLISH COMMON LAW IN MALAYSIA ....................................................67

III CONSTITUTIONAL PROTECTION OF PRIVACY .......................72

A The Relationship between the Common Law and the

Constitution ........................................................................... 72

B Fundamental Liberties under the Constitution.......................74

$1 \quad$ Article 5 right to life and personal liberty...................75

2 Approach to constitutional interpretation..................76

3 Judicial interpretation of article $5 \ldots \ldots \ldots \ldots \ldots \ldots \ldots \ldots . . .78$

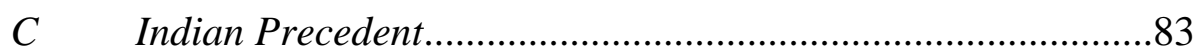

IV EXISTING COMMON LAW PRINCIPLES FOR THE

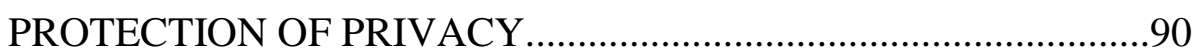

A Defamation.......................................................... 91

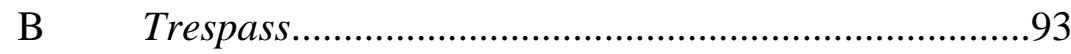

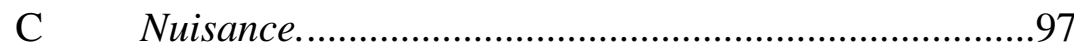

D Trade secrets and breach of confidence ......................99

V JUDICIAL DEVELOPMENT OF THE RIGHT TO PRIVACY....101

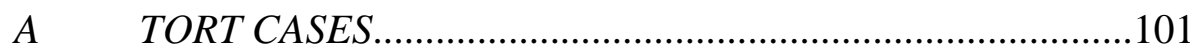

1 Denying the existence of the tort.............................101 


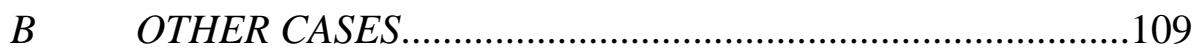

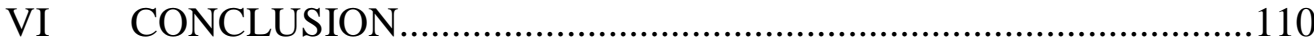

\section{CHAPTER FOUR}

\section{A COMPARATIVE EXAMINATION OF STATUTORY PROTECTION OF PRIVACY IN MALAYSIA..............112}

I OVERVIEW

II RELEVANT STATUTES FOR THE PROTECTION OF

PRIVACY.

A CRIMINAL LAW.......................................................113

B OTHER STATUTORY PROTECTION ..............................118

III PERSONAL DATA PROTECTION ACT 2010.............................121

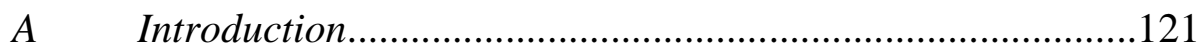

$1 \quad$ Salient features.....................................................124

2 Personal Data Protection Principles.........................128

$3 \quad$ Rights of data subject............................................131

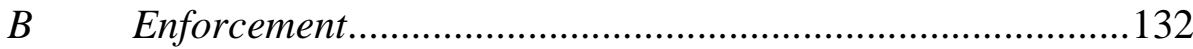

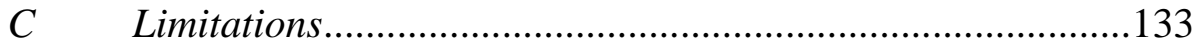

IV DATA PROTECTION ACT 1998....................................136

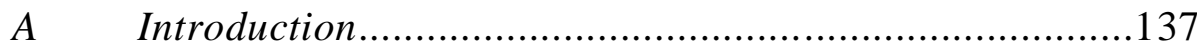

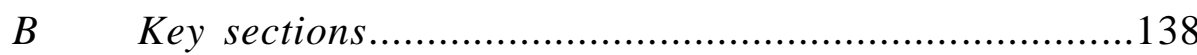

C Data protection principles and rights of data subjects.....140

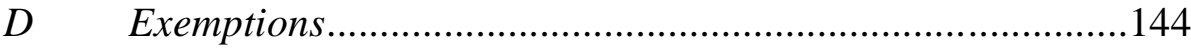

V PRIVACY ACT 1993 ...................................................145

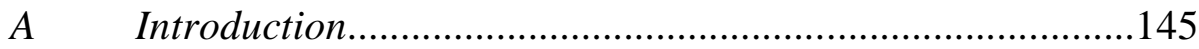

B The scope and operation........................................147

C Information privacy principles............................................149

D Exemptions and enforcement............................153

VI REMEDYING THE DEFECTS............................................154 


\section{CHAPTER FIVE}

\section{PROTECTION OF PRIVACY INTERESTS IN ENGLISH}

LAW

I OVERVIEW 162

II THE FRAMEWORK FOR THE PROTECTION OF PRIVACY.....165

A COMMON LAW. .167

B TRADITIONAL BREACH OF CONFIDENCE ACTION .......170

III BREACH OF CONFIDENCE POST-HUMAN RIGHTS ACT 1998

A THE IMPACT OF THE HRA 1998 ON THE LAW OF

PRIVACY

B BALANCING COMPETING CONVENTION RIGHTS.........180

$C$ DOUGLAS AND THE NEW METHODOLOGY.

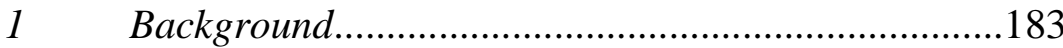

2 The articulation of the right to privacy......................184

IV PRIVACY POST-HUMAN RIGHTS ACT 1998_............................192

A THE TORT OF MISUSE OF PRIVATE INFORMATION....192

$1 \quad$ Utilisation of breach of confidence action..................194

2 The formulation of the privacy action.......................196

(a) Reasonable expectation of privacy test.......196

(b) Highly offensive to a "reasonable person of ordinary sensibilities" test......................197

3 Rejection of the "highly offensive element"...........198

B THE DEVELOPMENT OF PRIVACY ACTIONS SINCE

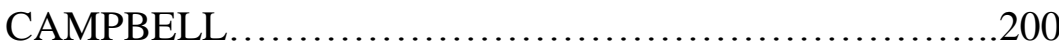

C PROTECTION AGAINST INTRUSION .........................205 


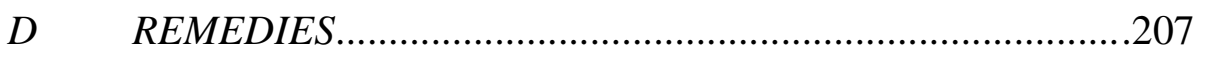

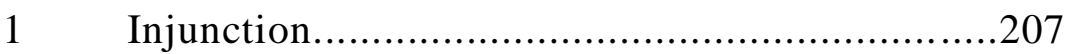

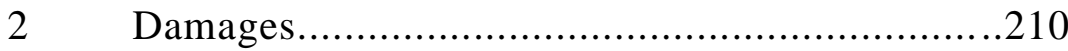

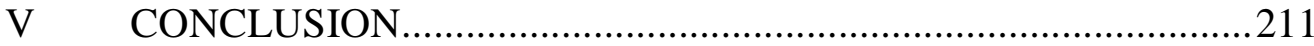

\section{CHAPTER SIX}

\section{PROTECTION OF PRIVACY INTERESTS IN NEW}

ZEALAND................................................213

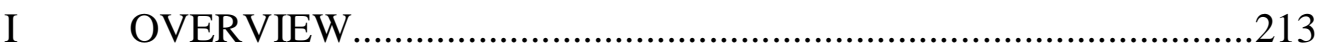

II CONSTITUTIONAL SUPPORT FOR A PRIVACY TORT ..........215

A PRIVACY AND FREEDOM OF EXPRESSION.................217

B PRIVACY AND UNREASONABLE SEARCH AND

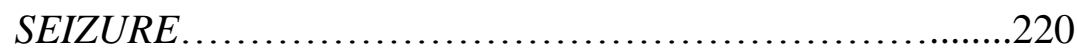

III PROTECTION OF PRIVATE INFORMATION.......................222

A COMMON LAW PRIVACY TORT: PRE-HOSKING.............223

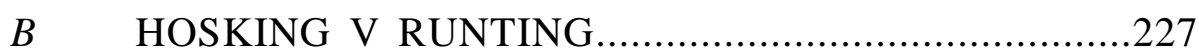

$1 \quad$ Background of facts and decision.....................227

2 The rejection of the UK approach ..................232

$3 \quad$ Requirements of the privacy tort........................234

(a) Reasonable expectation of privacy..............234

(b) Highly offensive to an objective reasonable person............................................238

(c) The defence of legitimate public concern...........240

(d) Remedies...............................................242

C DEVELOPMENTS AFTER HOSKING.....................243

IV PROTECTION AGAINST INTRUSION...............................253

A LEGISLATION AND CASE LAW...........................253

B TORT OF INTRUSION UPON SECLUSION:

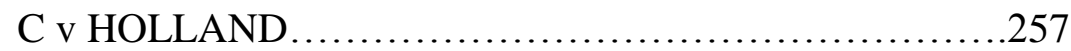

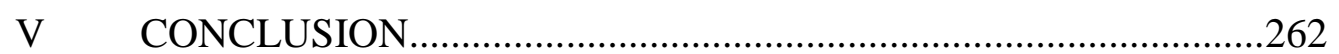




\section{PART IV: PROPOSAL}

\section{CHAPTER SEVEN}

A PRIVACY LAW FOR MALAYSIA............................................265

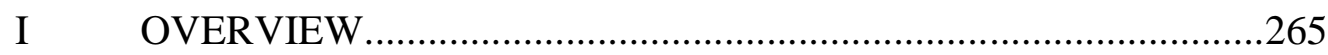

II NEED FOR A BILL...................................................................267

III EXPLANATION OF THE BILL'S PROVISIONS...........................271

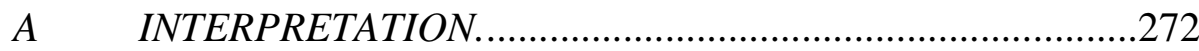

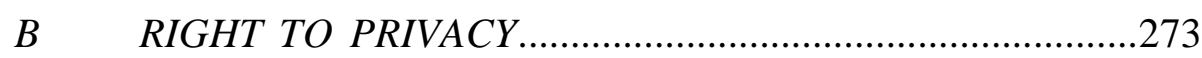

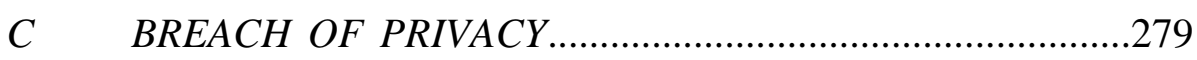

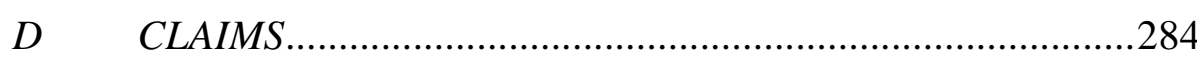

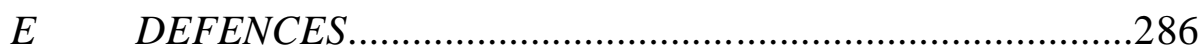

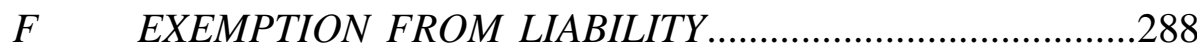

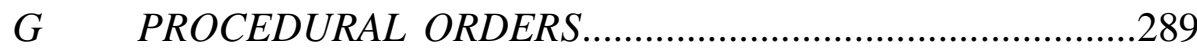

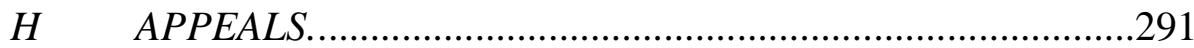

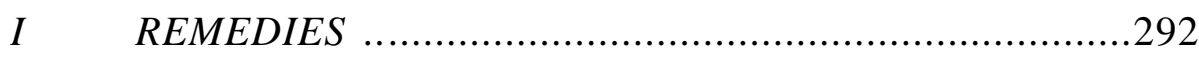

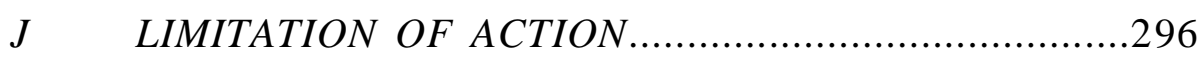

K PERSONAL DATA PROTECTION PRINCIPLES.........296

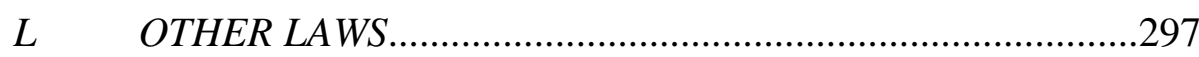

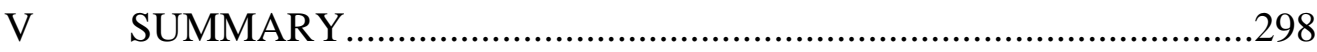

\section{CHAPTER EIGHT}

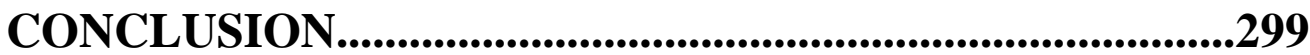

APPENDIX .....................................................................................302

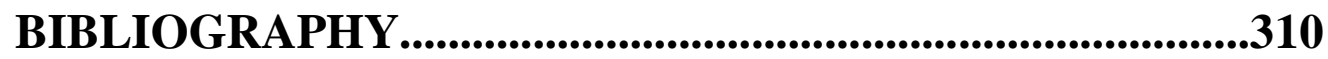

A LEGISLATION.............................................................

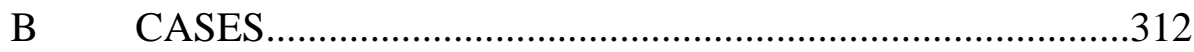

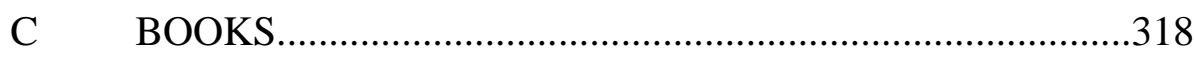


D JOURNAL ARTICLES AND ESSAYS IN EDITED

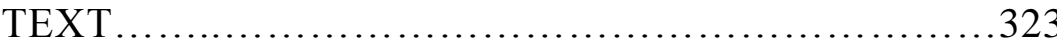

E LAW REFORMS, REPORTS AND ISSUES PAPER.........329

F THESES, WORKING, RESEARCH, SEMINAR PAPER...330

G NEWSPAPER ARTICLES AND MEDIA RELEASE......331

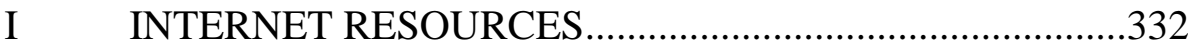




\section{LIST OF ABBREVIATIONS}

\begin{tabular}{|c|c|}
\hline ASEAN & Association of Southeast Asian Nations \\
\hline CLA & Civil Law Act 1956 (Malaysia) \\
\hline $\mathrm{CPC}$ & Criminal Procedure Code (Malaysia) \\
\hline CRA & Credit Reporting Agency Act 2010 (Malaysia) \\
\hline ECHR & European Convention on Human Rights \\
\hline FC & Federal Constitution (Malaysia) \\
\hline $\mathrm{HCA}$ & High Court Australia \\
\hline HRA & Human Rights Act 1998 (UK) \\
\hline HRCA & Human Rights Commission Act 1999 (Malaysia) \\
\hline ICCPR & $\begin{array}{l}\text { International Covenant on Civil and Political Rights } \\
1996\end{array}$ \\
\hline IRD & Inland Revenue Department \\
\hline LPA & Legal Profession Act 1976 (Malaysia) \\
\hline NLC & National Land Code 1965 (Malaysia) \\
\hline NZ & New Zealand \\
\hline NZBORA & Bill of Rights Act 1990 (NZ) \\
\hline OECD & $\begin{array}{l}\text { Organisation for Economic Cooperation and } \\
\text { Development }\end{array}$ \\
\hline PA & Privacy Act 1993 (NZ) \\
\hline PDPA & Personal Data Protection Act 2010 (Malaysia) \\
\hline TVNZ & Television New Zealand, Limited \\
\hline UDHR & Universal Declaration of Human Rights 1948 \\
\hline UK & United Kingdom \\
\hline & United States \\
\hline
\end{tabular}




\section{PART I: CONTEXT \\ CHAPTER ONE \\ INTRODUCTION}

\section{Overview}

Privacy is one of the values flowing from the principles of human dignity and autonomy. ${ }^{1}$ It goes to the heart of human rights and liberal philosophy and history. ${ }^{2}$ Although there are many definitions of privacy, the common feature is that privacy is a basic human right that warrants legal protection.

This thesis examines the existing framework for the protection of privacy in Malaysia. Its central contention is that the laws currently available are inadequate to deal with breaches of privacy. It is argued that the development of privacy law in the United Kingdom (UK) and the recognition of privacy torts in New Zealand (NZ) can inform the development of a model law for Malaysia.

To prove this contention, the thesis does four things: first, it analyses the constitutional and common law protection of privacy in Malaysia to illustrate its inadequacies to protect privacy; second, it examines the development of the law of privacy as a result of changes brought by the Human Rights Act 1998 (HRA) and privacy cases in the UK; third, it evaluates the courts'

\footnotetext{
${ }^{1}$ Edward Bloustein "Privacy as an Aspect of Human Dignity: An Answer to Dean Prosser" (1964) 39 NYULR 962 ["Privacy as an Aspect of Human Dignity"]. See also NA Moreham "Why is Privacy Important? Privacy, Dignity and Development of the New Zealand Breach of Privacy Tort" in Jeremy Finn and Stephen Todd (eds) Law, Liberty, Legislation (LexisNexis, Wellington, 2008). See also the discussion of the notion of privacy in Chapter Two.

${ }^{2}$ The human right to privacy has its contemporary international origins in art 12 of the Universal Declaration of Human Rights (UDHR). See also Isaiah Berlin "Two Concepts of Liberty" (1958) in Isaiah Berlin (1969) Four Essays on Liberty (Oxford University Press, London, 1969). The right is also discussed by Hugh Collins "The Decline of Privacy in Private Law" (1987) 14 (1) Journal of Law and Society 91, where the author stated that the principle of privacy delineates a realm of conduct which the state cannot justifiably regulate. The principle plays a central role in liberal political theory, since it colours many liberals' conception of personal freedom.
} 
formulation of privacy torts in NZ; and fourth, it proposes a future law of privacy for Malaysia inspired by these developments. The possibility of a general tort of privacy, the introduction of specific legislation on privacy, and the recognition of the right to privacy in the Constitution are evaluated to better protect the right to privacy in the Malaysian context.

\section{The problem}

Malaysia recognises the rights and liberties of the individual in the Constitution as part of human rights protected by the supreme law of the land. However, the right to privacy has not received the express constitutional recognition enjoyed by rights such as the right to life and liberty, the right to property, freedom of expression, movement and association, freedom of religion and equality. Further, there is no general right to privacy in Malaysia, though there are several laws which relate to privacy. The Personal Data Protection Act 2010 (PDPA) was passed to protect personal information but it has limited application. Thus, this thesis argues that the law is inadequate to protect privacy rights and particularly private information. The transplantation of foreign principles through the reception of the English common law of trespass, nuisance, defamation and breach of confidence are seen to be inadequate to protect privacy.

The absence of specific law on privacy leads to a lack of remedies for victims whose private lives and personal information have been invaded. For example, on 20 August 2007, an 8 year old girl named Nurin, a student of one of the primary schools in Kuala Lumpur was reported missing after going out alone to a night market near her house. The case received wide media coverage when her body was found in a bag outside business premises on 17 September 2007. A post-mortem report revealed that Nurin's death was due to sexual abuse. Post-mortem photographs were circulated on the internet, thus available for public viewing. Two policemen were liable for the circulation of these photographs. The negligence suit was settled out of court when Jazimin 
Abd Jalil, Nurin's father agreed to withdraw his suit against the other four defendants. Although the case was withdrawn, the publication of distressing photographs was no doubt a great invasion of the victim's family. The parties agreed not to disclose the terms of settlement to the media. ${ }^{3}$

In most privacy cases in other jurisdictions, celebrities or entertainers are often the victims of breach of privacy, and Malaysia is no exception. The case of a local celebrity, Nasha Aziz, an actress and model, is one example. She complained that her privacy had been intruded upon when a closed-circuit camera (CCTV) was installed in her apartment and videotaped her daily routine, which included footage of her undressing. The Magistrate's Court in 2004 ruled that the man who installed the camera was guilty of two charges; trespassing into the celebrity's apartment, and intruding upon her privacy by installing a closed circuit camera operating between April and July 2002. The man was sentenced to six month's jail for each offence. The appeal against the conviction was dismissed. In upholding the sentence, the Court of Appeal found that the man's actions were a great invasion which destroyed the actress's privacy. ${ }^{4}$

The victims of invasion of privacy cases may take an action against the intruder or trespasser for trespassing, but not against the publication of photographs. If they do wish to commence such an action, it must be under criminal law. ${ }^{5}$ For instance, in 2009, a video of Chua Soi Lek, a Malaysian Chinese Association (MCA) high council member having sex with an unknown woman, was circulated on the internet. The video was believed to be recorded by a hidden camera in the hotel where he was staying. After the circulation of the video, Chua Soi Lek admitted that he was the person in the

\footnotetext{
${ }^{3}$ M Mageswari "Nurin's dad reaches out-of-court settlement in negligence suit against government" The Star Online (Malaysia, 29 November, 2010).

"Nasha spy camera case: Supervisor loses appeal" The Star Online (Malaysia, 6 October 2008); See also "Judges send man who fixed spy camera in model's home to prison" The Star Online (Malaysia, 7 October 2008).

${ }^{5}$ For example s 292 of the Penal Code provides an offence relating to sale, distribution, hire or offer of obscene books etc. which carries a three year jail term or fine or both and s 509 of the same Code which provides penalties for intending to insult the modesty of any person.
} 
video and resigned from his posts in the party after the circulation of the video. Police carried out an investigation and warned that it was an offence to possess and distribute copies of such DVDs, and that those found guilty of doing so would be charged under the obscenity provision of s 292 of the Penal Code. ${ }^{6}$ Punishment may deter the offender, but it is doubtful whether it compensates for the loss suffered by the subject of the videos. This kind of protection is lacking in Malaysia law.

Because the right to privacy is hard to maintain, especially by public figures, it means that all aspects of their lives can be shared with the public. In 2008 , photos of a member of the Bukit Lanjan State Assembly, Elizabeth Wong, sleeping naked, were publically circulated by mobile phone and internet. The photos were taken by her ex-boyfriend, Hilmi Malik who disappeared after the incident. As a result of the release of the photos by unknown persons, she resigned from all her posts in the party and state government. However, following the request that she remain in office, she revoked her decision and retained her positions. ${ }^{7}$ The public release of the photographs was a serious breach of her privacy, but even if the culprits were known, no civil action could have been taken against them.

In 2010, Noor Haslina received a package containing nine A4-sized sheets of paper with information about her short messages services (SMS) exchanges and a pen drive recording her phone conversations. She filed a RM20 million claim against telecommunication company, Celcom Axiata Berhad for alleged breach of privacy involving her SMS exchanges and recordings of her telephone conversations, breach of confidence, contract and negligence. However, her case was dismissed by the High Court in 2012 because she failed to prove that Celcom had revealed her SMS and recordings of her

\footnotetext{
${ }^{6}$ See "Police launch probe, warn of penalties for having video" The Star Online (Malaysia, 2 January 2008).

${ }^{7}$ Christina Tan "Eli Wong back at work" The Star Online (Malaysia, 16 April 2009) and "Elizabeth Wong just wants to get back to work" The Star Online (Malaysia, 17 April 2009).
} 
mobile phone conversations to a third party. ${ }^{8}$ This case showed that although there was disclosure of private conversations, and that there was a breach of an individual's privacy, she could not maintain any claim due to inadequate law in Malaysia.

The above incidents illustrate that in the $21^{\text {st }}$ century, infringements of privacy such as disclosure of personal information, intrusion, wiretapping and surveillance have become extensive and Malaysia is no exception. These infringements are frequently the subject of newspaper headlines. ${ }^{9}$ Apart from the above examples, a person's financial standing, sex life, sexual orientation, marital status, health and family and social relationships should not be a subject of public discussion. Such public exposure interferes with individual privacy and should be actionable unless the discussion is for the interest of the public as a whole. These problems are serious as are their consequences. Better law is needed to address these issues.

\section{III}

\section{The Scope of Research and Aims of Study}

This research focuses on the protection of privacy interests in Malaysia. It analyses general problems relating to public disclosure of private facts and protection against intrusions into for instance, physical space and bodily integrity. Issues such as the adequacy of the existing laws and data protection legislation, the competing interests of freedom of expression and limits on privacy will be discussed.

The situation in Malaysia is the core of this study, but the UK and New Zealand's legal positions will also be examined. The UK's position is relevant for two reasons. First, it is relevant because of the influence of the English

\footnotetext{
${ }^{8} \mathrm{M}$ Mageswari "High Court dismisses breach of privacy claims against Celcom Axiata" The Star Online (Malaysia, 17 March 2012).

${ }^{9}$ See also Foong Cheng Leong "Right to privacy in Malaysia: Do we have it" The Malaysian Insider (Malaysia, 21 Februari 2011). The author gave examples of invasion of privacy occurrences in Malaysia.
} 
Common Law on the Malaysian legal system before independence. ${ }^{10}$ Until 31 December 1984 the Privy Council was the highest court of appeal in Malaysia pursuant to art 131 of the Federal Constitution (FC). After 1 January 1985, appeals to the Privy Council were abolished and the Federal Court became the highest court in Malaysia. Since then, reference to English law is made in deciding local cases, however, English law is not binding on local courts. ${ }^{11}$

Second, the details of the UK cases are illuminating for Malaysia to develop its privacy law. This thesis will analyse the emergence of privacy protection in the UK which developed from an action for breach of confidence and examine how the UK courts introduced an action for misuse of private information as a tool for an action involving breach of privacy ${ }^{12}$. The introduction of the HRA has had a significant impact on the development of privacy in the UK. Though the right to privacy is recognised through the incorporation of the European Convention on Human Rights (ECHR), the idea of the HRA creates a horizontal application of the right. English courts have not yet recognised an "over-arching, all-embracing cause of action for invasion of privacy", but as Campbell v MGN Ltd ${ }^{13}$ and Douglas $v$ Hello $L t d^{14}$ show, the HRA and the ECHR have provided the impetus for expansion of the action for breach of confidence to provide remedies to people who complain of wrongful publication of private matters. Thus, in spite of courts' reliance on the HRA, the UK's experience of formulating the element of the action for privacy provides useful guidance for Malaysia.

The New Zealand law on privacy is referred to because Malaysia and New Zealand are both common law countries with similar legal structures and legal values. Each country has developed the law in a way which could be emulated in Malaysia but importantly each has taken a slightly different approach. Despite the route taken by the English courts in extending the action for

\footnotetext{
${ }^{10}$ Malaysia was a British colony from 1824-1957.

${ }^{11}$ The applicability of English law in Malaysia is discussed in Chapter Three, Part II.

${ }^{12}$ This development is discussed in Chapter Five.

${ }^{13}$ [2004] UKHL 22 (HL) (Campbell).

${ }^{14}[2001]$ QB 967 (CA) (Douglas).
} 
breach of confidence to cover misuse of private information, the New Zealand courts adopted a completely different approach when the Court of Appeal in Hosking $v$ Runting ${ }^{15}$ recognised a tort of invasion of privacy. It was held that the tort would be committed where a defendant published facts about the private life of a person, where giving publicity to such facts would be considered "highly offensive to an objective reasonable person". The approach of expanding the duty of confidence was rejected on the basis that privacy and confidence are different concepts. Eight years later, in 2012, the High Court moved a step ahead when it recognised a tort of intrusion upon seclusion as part of New Zealand law. ${ }^{16}$ The New Zealand experience of judicial activism is practical for Malaysia based on recent Malaysian privacy cases that incline towards recognising privacy as a tort.

Both the UK and NZ development in the area of privacy law inspire Malaysia to provide better protection in its privacy framework.

This study aims to suggest ways and to develop the law on the protection of personal information and protection against intrusion so as to provide a comprehensive legislative framework for a privacy action. It assesses the existing protection available in the UK and New Zealand to measure its effectiveness to address privacy problems in the Malaysian context. It analyses what Malaysia can learn from both jurisdictions; they provide direction as to what kind of privacy protection should exist in Malaysia. In brief, the prime objective of the research is to establish that there are inadequacies of privacy protection in Malaysian laws which result in lack of remedies to victims in cases of invasion of privacy.

This research will enhance the knowledge of all relevant parties concerning various aspects of privacy protection particularly disclosure of private information and the protection against intrusion. The outcome of the thesis

\footnotetext{
${ }^{15}$ Hosking v Runting [2005] 1 NZLR 1 (CA) (Hosking).

${ }^{16}$ See $C$ v Holland [2012] NZLR 672 (HC) (Holland). The details of New Zealand law of privacy is discussed in Chapter Six.
} 
will not only establish a cause of action in privacy but provide the victim with appropriate remedies for the breach.

\section{The Structure of Study}

This thesis is divided into four parts and contains eight chapters. Part I contains Chapters One and Two which introduce the thesis. Part II presents current protections in Malaysia which are discussed separately in Chapters Three and Four. Part III, Chapters Five and Six, examines comparative models for privacy protection in Malaysia. Part IV contains Chapters Seven and Eight which present the proposal and conclusion of the thesis.

Chapter One highlights the area of study that focuses on the privacy problems in Malaysia and the need for protection in Malaysian law. It reviews general problems of privacy and clarifies the objectives of the study: the inadequacy of the existing legal framework for privacy protection in Malaysia. It explains that the development of the law of privacy in the United Kingdom and New Zealand will be examined as possible models for Malaysia.

Chapter Two examines various definitions of privacy in order to establish a theoretical framework for privacy. It divides the discussion into a Western concept of privacy, an Islamic, and Malaysian perspectives. It also analyses categories of privacy and aspects of privacy protection. According to the review of the literature, the study defines privacy as unwanted access to a person or information about a person.

Chapter Three presents the existing Malaysian legal landscape for privacy protection. It begins with a general discussion of the application of English common law in Malaysia. It also discusses constitutional protection of privacy derived from an entrenched right to life and personal liberty. The existing common law principles for privacy related interests such as private facts, reputation and proprietary interests are discussed to demonstrate the 
inadequacies of current protection. The judicial developments of the right to privacy in Sivarasa v Badan Peguam Malaysia ${ }^{17}$ and other privacy cases ${ }^{18}$ are also analysed to ascertain the possibility of developing the right in the courts.

Chapter Four examines all legislative protections for privacy in Malaysian law. It discusses criminal and other statutory protection that could be invoked to protect privacy. It discusses the Personal Data Protection Act 2010 (PDPA), the UK Data Protection Act 1998 (DPA), and the New Zealand Privacy Act 1993 (PA), for the purpose of comparison and the possibility of remedying defects in the PDPA in Malaysia. Examination of the law confirms that the PDPA is not adequate to protect privacy as defined in Chapter Two.

Chapter Five evaluates the state of privacy, its development and legal framework to accommodate privacy in the English law. It examines privacy protection through the doctrine of breach of confidence before and after the introduction of the HRA. The effect of the incorporation of the European Convention on Human Rights on the existing framework is examined. This chapter also analyses the development of the law of privacy as effected by Douglas $^{19}$ and Campbell ${ }^{20}$ in particular, the tort of misuse of private information. It also discusses the utilisation of the test of reasonable expectation of privacy in subsequent cases.

Chapter Six focuses on the development of privacy protection in New Zealand. It examines the tort of public disclosure of private facts recognised in Hosking $v$ Runting. ${ }^{21}$ The development and application of the tort in subsequent cases are analysed. The newly recognised action as highlighted in

\footnotetext{
${ }^{17}$ [2010] 3 CLJ 507 (FC) (Sivarasa).

${ }^{18}$ There are a few cases which discussed privacy as a right in Malaysia, for example, $D r$ Bernadine Malini Martin v MPH Magazines Sdn Bhd \& Ors [2006] 2 CLJ 1117 (HC), Maslinda Ishak v Mohd Tahir Osman \& Ors [2009] 6 MLJ 826, [2009] 6 CLJ 653 (CA), and Lee Ewe Poh v Dr Lim Teik Man \& Anor [2011] 1 MLJ 835 (HC), and Lew Cher Phow @ Lew Cha Paw \& Ors v Pua Yong Yong \& Anor [2011] MLJU 1195 (HC).

${ }^{19}$ Above $\mathrm{n} 14$.

${ }^{20}$ Above $\mathrm{n} 13$

${ }^{21}$ [2005] 1 NZLR 1 (CA) (Hosking).
} 
Holland $^{22}$ which extends an aspect of privacy protection to intrusion upon seclusion will be examined as this development offers a comprehensive protection of privacy interests in current New Zealand law.

Chapter Seven proposes the direction that Malaysia should take, and suggests the shape of privacy law for Malaysia as informed by the United Kingdom and New Zealand experiences. It concludes that specific legislation on privacy is desirable in order to provide adequate protection for privacy. The key part of the thesis, is the proposal of a draft Privacy Bill. The proposed law will provide protection to both aspects of privacy, namely personal information and intrusions. Detailed explanations for each clause of the proposed legislation are provided in Chapter Seven. The gaps in the Personal Data Protection Act 2010 are remedied through the reforms suggested.

Chapter Eight summarises the main issues and presents the results of the thesis.

\section{Summary}

The right to privacy is an important right. It needs protection similar to other fundamental rights accorded special recognition in the Constitution. The absence of a privacy right in the Constitution does not mean that it is totally disregarded, as legislation and common law principles are available to protect privacy-related interests. However, the availability of privacy related interests protection grounded in common law actions for trespass, breach of confidence, defamation, breach of contract and passing off have not adequately provided remedies for a breach of privacy in Malaysia.

This legal structure is parallel to that of the UK and New Zealand as cases involving invasion of privacy have their basis in the common law principles for defamation, trespass, nuisance and breach of confidence. Judges often

\footnotetext{
${ }^{22} \mathrm{C} v$ Holland, above $\mathrm{n} 15$.
} 
refer to existing causes of action rather than formulate a new head of liability. However, with the development of case law in the UK and New Zealand respectively, ${ }^{23}$ the nature of privacy protection changed when the court recognised a tort of unjustified publication of private information and intrusion upon seclusion. This recognition has made the question of whether there is a right to privacy redundant. The focus is now on protection and the ability to provide remedies for cases involving invasion of privacy. The developments that have taken place in the UK and New Zealand can provide lessons for Malaysians seeking to make similar changes.

The concept of privacy, its scope and the kind of protection Malaysia should have for invasion of privacy will be examined in the next chapter in which a definition of privacy for the purpose of the thesis will be formulated.

\footnotetext{
${ }^{23}$ The development can be seen in Campbell, Hosking and, Holland.
} 


\section{CHAPTER TWO PRIVACY FROM DIFFERENT PERSPECTIVES}

\section{Overview}

Privacy is an elastic concept and difficult to define. ${ }^{1}$ As outlined in Chapter One, the aim of this thesis is to offer suggestions for legislating against breaches of privacy. However, protection will be meaningless without defining what kind of interest is to be protected. The definition of privacy and its importance must be established. Western, Islamic and Malaysian concepts of privacy will greatly influence the formulation of the meaning of privacy for the thesis, and thus establish the shape of privacy protection for Malaysia.

The Western perspective of privacy is useful for the definition of privacy developed in the thesis because it appears not to contradict either Islamic concepts of public and private affairs or Malaysian custom and tradition. Thus, this thesis does not offer a completely new theory of privacy; rather it develops what already exists within the Malaysian context.

This chapter is divided into five parts. Part I outlines the subjects of discussion in Chapter Two. Part II sketches the general notion of privacy and its importance as a human right and a human value. Part III discusses the

\footnotetext{
${ }^{1}$ See Robert C Post "Three Concepts of Privacy” (2001) 89 Geo LJ 2087 [“Three Concepts of Privacy"]. Post said that "privacy is a value so complex, so entangled in competing and contradictory dimensions, so engorged with various and distinct meanings, that I sometimes despair whether it can be usefully addressed at all" at 2087; see also Eoin Carolan "The Concept of a Right to Privacy" (2011) 〈http://ssrn.com/abstract=1889243〉. Carolan expressed the view that privacy is a notoriously elastic and equivocal notion; the same was claimed by Allen, see Anita L Allen Uneasy Access: Privacy for Women in a Free Society (Random and Littlefield, Totowa, 1988); Miller has declared that privacy is "difficult to define because it is exasperatingly vague and evanescent", see Arthur R Miller The assault on privacy: computers, data banks, and dossiers (University of Michigan Press, Ann Arbor, 1971). This view was also stated by Daniel J Solove "Conceptualizing Privacy" (2002) 90(4) California Law Review 1087, at 1088.
} 
Western conception of privacy from the point of view of well-known theoretical definitions of the right to be let alone and the right to control information and access to the self. It also examines privacy as a state and condition of inaccessibility and provides arguments of commentators against the "control definition" of privacy. Part IV considers the nature of privacy from the Islamic principles of public and private spheres. Part $\mathrm{V}$ touches generally on Malaysians' perception of privacy especially from the perspective of the traditional Malay society. Part VI concludes the overall discussion of the concept of privacy, provides a definition of privacy for the thesis and justifies its importance to every individual who needs protection in every aspect of privacy.

\section{The Notion of Privacy and Its Importance}

The right to privacy is a fundamental human right and is recognised in numerous international covenants and declarations. ${ }^{2}$ However, Clayton and Tomlinson argue that, although most modern international human rights instruments protect the right of the individual to "privacy" and "private life", there is no clear definition of the right available. ${ }^{3}$ This argument is wellfounded due to the breadth of the concept of privacy and the absence of a general right to privacy in English law. As far as privacy is concerned, protection depends on each jurisdiction's treatment of the right to privacy. ${ }^{4}$

\footnotetext{
${ }^{2}$ Art 12 of UDHR reads, "No one shall be subjected to arbitrary interference with his privacy, family, home or correspondence, nor to attacks upon his honour and reputation. Everyone has the right to the protection of the law against such interference or attacks" [Emphasis added]. Besides, international treaties such as the International Covenant on Civil and Political Rights 1966 (ICCPR), the European Convention on Human Rights 1950, the Organisation for Economic Cooperation and Development (OECD), the Council of Europe and EU Directives are the frameworks that provide protection for aspects of privacy rights.

${ }^{3}$ Richard Clayton and Hugh Tomlinson The Law of Human Rights $\left(2^{\text {nd }}\right.$ ed, Oxford University Press, 2009) [The Law of Human Rights] at 1005.

${ }^{4}$ For example, there are countries such as India which implicitly recognise the right to privacy in the Constitution though it is not specifically mentioned rather it is available through the protection of personal rights. On the other hand, the UK law extended the breach of confidence action to protect misuse of private information, and the New Zealand courts acknowledged privacy as a tort.
} 
From a human rights perspective, privacy relates to the idea of liberty which is at the heart of freedom, but it is not well established compared to other civil rights such as life, liberty, property, religion or freedom from slavery. ${ }^{5}$ It is generally agreed by commentators that at the heart of the right to privacy lies the notion of personal liberty and autonomy. ${ }^{6}$ That notion offers various definitions of privacy and the scope of the right to privacy. In the context of human rights law, Clayton and Tomlinson categorise privacy issues under four headings: ${ }^{7}$

(a) Misuse of personal information. A right to restrict the use of "personal" or "private" information about an individual is central to the right to privacy. The information which is held by public bodies is open to abuse. Privacy issues arise when the release of the information is uncontrolled.

(b) Intrusion into the home. The right of the individual to respect for the home is fundamental to any notion of privacy. Unreasonable searches and seizures trigger privacy issues.

(c) Photography, surveillance and telephone tapping. The "private sphere" is invaded not only by physical intrusion into the home. The right to privacy is generally understood to extend to private correspondence.

(d) Other privacy rights. There is a range of other privacy rights which covers all forms of interference in the "private sphere" including appropriation of a person's image, interference with private sexual behaviour and questions of the sexual identity of transsexuals.

The above types of privacy concern are broad and require appropriate protection for every individual, provided that the privacy interests intended to be protected are not inconsistent with the interest of the public at large. This balancing of interests justifies the guarantee of freedom and liberty of every

${ }^{5}$ Clayton and Tomlinson The Law of Human Rights, above n 3, at 1005.

${ }^{6}$ David Feldman Civil Liberties and Human Rights in England and Wales $\left(2^{\text {nd }}\right.$ ed, Oxford University Press, 2002), Chap 9; see also E Barendt "Privacy as a Constitutional Right and Value" in B Markesinis (ed) Protecting Privacy (Oxford University Press, 1999). See also James Q Whitman "The Two Western Cultures of Privacy: Dignity Versus Liberty" (2004) 113 Yale LJ 1151.

${ }^{7}$ Clayton and Tomlinson The Law of Human Rights, above n 3, at 1007. 
citizen by the state, and at the same time acknowledges privacy as an important human value.

Appreciating the need for an appropriate protection of privacy relates to the importance of privacy as a human value with associated attributes of dignity and autonomy. ${ }^{8}$ Moreham views privacy as fundamentally connected with respect for human dignity and this is the principal reason that it should be protected. ${ }^{9}$ She argues that although privacy facilitates many valuable ends, its importance lies principally in the fact that it is integrally connected to a person's fundamental entitlement to respect, ${ }^{10}$ and invasion takes place when there is a failure to show "proper regard for human dignity". 11 The categorisation of a "dignitary tort" identified by Cane shows that violation of privacy is a violation of human dignity. ${ }^{12}$

Most privacy authors agree that privacy is important because it supports other values essential for human flourishing. ${ }^{13}$ Bloustein perceives privacy as an aspect of human dignity where damage and loss suffered by invasions of privacy cannot be repaired by an award of damages. For him the harm resulting from infringement of privacy affects the individual and human dignity. $^{14}$

\footnotetext{
${ }^{8}$ The term autonomy refers to each individual's capacity to be self-determining, in the sense of being free to "live their life in accordance with their own particular ideas of the individual good." Refer Beate Rossler The Value of Privacy (Polity Press, Cambridge, 2005); see also Chris DL Hunt "Conceptualizing Privacy and Elucidating its Importance: Foundational Considerations for the Development of Canada's Fledgling Privacy Tort" (2011) 37(1) Queen's LJ 167 ["Conceptualizing Privacy and Elucidating its Importance"] at 205.

${ }^{9}$ NA Moreham "Why is Privacy Important? Privacy, Dignity and Development of the New Zealand Breach of Privacy Tort" in Jeremy Finn and Stephen Todd (eds) Law, Liberty, Legislation (LexisNexis NZ Limited 2008) [“Why is Privacy Important?”] at 238.

${ }^{10}$ At 231.

${ }^{11}$ At 236

${ }^{12} \mathrm{P}$ Cane The Anatomy of Tort Law (Oxford, Hart Publishing, 1997) at 71-74.

${ }^{13}$ Moreham, "Why is Privacy Important?" above n 9, at 233-234. The author refers to a number of commentators that have recognised the relationship between privacy and dignity. ${ }^{14}$ Bloustein "Privacy as an Aspect of Human Dignity", above ch $1 \mathrm{n} 1$, at 1003. He said that all invasions of privacy are violations of human dignity.
} 
Post regards violation of privacy as the injury of betrayal which comes from the violation of confidence. The harm or injury, according to him, derives from the rupture of mutual understandings of confidentiality between individuals to assumptions that private conversation will not be disclosed. ${ }^{15}$ Thus, privacy and dignity are closely grounded in social forms of respect towards each other as members of a common community. ${ }^{16}$

The importance of privacy has also been considered by courts before delivering judgments. For example in Campbell v MGN Ltd, ${ }^{17}$ Lord Hoffman acknowledged private information as something worth protecting and categorised it as an aspect of human autonomy and dignity: ${ }^{18}$

The new approach...focuses upon the protection of human autonomy and dignity - the right to control the dissemination of information about one's private life and the right to the esteem and respect of other people.

In the same case, Lord Nicholls perceived privacy in a wider sense, as essential for the well-being and development of an individual. ${ }^{19}$ This statement suggested that privacy is one of the elements needed to maintain a person's integrity and value for the development of human good. ${ }^{20}$

\footnotetext{
${ }^{15}$ Post "Three Concept of Privacy", above n 1, at 2091-2092.

${ }^{16}$ At 2092.

${ }^{17}[2004]$ UKHL 22 (Campbell).

${ }^{18}$ At [51].

${ }^{19}$ At [12].

${ }^{20}$ Hunt "Conceptualizing Privacy and Elucidating its Importance", above n 8, at 202. The author referred to David Lindsay "An Exploration of the Conceptual Basis of Privacy and the Implications for the Future of Australian Privacy Law" (2005) 29(1) Melbourne University LR 131 and discussed the importance of privacy from deontological and consequentialist approaches. Deontologists see privacy as an aspect of dignity, autonomy and personhood, while consequentialists perceive the importance of privacy from the promotion of various good.
} 
Beside English cases, the European Court of Human Rights in Von Hannover $v$ Germany $^{21}$ held that the scope of protection under art 8 of the ECHR: ${ }^{22}$

...includes a person's physical and psychological integrity... and is primarily intended to ensure the development, without outside interference, of the personality of each individual in his relations with other human beings.

In New Zealand, Tipping $\mathrm{J}$ said in Hosking $v$ Runting ${ }^{23}$ in favour of the recognition of privacy tort: ${ }^{24}$

It is the essence of the dignity and personal autonomy and wellbeing of all human beings that some aspects of their lives should be able to remain private if they so wish.

The Malaysian High Court also considers the preservation of human dignity when dealing with privacy cases. For example, in Lee Ewe Poh v Dr Lim Teik Man \& Anor $^{25}$ the court held:

The privacy right of a female in relation to her modesty, decency and dignity in the context of the high moral value existing in our society is her fundamental right in sustaining that high morality that is demanded of her and it ought to be entrenched. Hence, it is just right that our law should be sensitive to such rights. In the circumstances, the plaintiff in the instant case ought to be allowed to maintain such claim.

In another Malaysian case, Lew Cher Phow @ Lew Cha Paw \& Ors v Pua Yong Yong \& Anor ${ }^{26}$ the court held:

\footnotetext{
${ }^{21}$ [2004] VI ECHR (Von Hannover).

${ }^{22}$ At [50].

${ }^{23}$ [2005] 1 NZLR 1 (CA) (Hosking).

${ }^{24}$ At [239].

${ }^{25}$ [2011] 1 MLJ 835 (HC), at [8].
} 
The act of carrying out overt surveillance on the plaintiff carries with it an implied threat that the fruits of the surveillance may be used for purposes adverse to the interests of the plaintiffs. In effect, this is clearly calculated to undermine the plaintiff's dignity, self-esteem, comfort and privacy. The defendants' continuing act of putting the plaintiffs under overt surveillance represents a failure of respect for the plaintiffs' dignity and autonomy.

The above cases show that it is generally accepted in both the Commonwealth and Malaysia that the importance of privacy lies in the protection of human dignity and autonomy, and is regarded as a fundamental consideration in deciding adequate protection for breaches of privacy. The significant value that attaches to privacy calls for a comprehensible definition of privacy.

Over the last century, there have been many approaches to defining privacy. As a result, there are numerous conceptions of privacy advanced by commentators and scholars from the famous "right to be let alone" ${ }^{27}$ to the most influential one in modern times of the right to "inaccessibility". ${ }^{28}$ This next part will discuss these definitions from the Western perspective and evaluate which definition is the best in the context of the thesis.

\section{Western Concepts of Privacy}

Privacy has been defined in different ways. The Oxford Dictionaries Pro ${ }^{29}$ defines privacy as "the state of being private and undisturbed; a person's right to this; freedom from intrusion or public attention". The definition conveys the idea that privacy is the condition of being secluded from the presence or

\footnotetext{
${ }^{26}[2011]$ MLJU 1195 (HC).

${ }^{27}$ SD Warren and LD Brandeis "The right to privacy" (1890)(4) Harv Law Review 193, at 195.

${ }^{28}$ Ruth Gavison "Privacy and the Limits of Law" (1980) 89 Yale LJ 421.

${ }^{29}$ The Oxford Dictionaries Pro < http://english.oxforddictionaries.com/definition/privacy $>$
} 
scrutiny of others. If the affairs of an individual are within the reach and knowledge of others, that person is not enjoying privacy as understood by this definition. This definition of privacy encompasses the four heads of privacy issue discussed by Clayton and Tomlinson. ${ }^{30}$

The first to articulate the concept of privacy as such in modern times ${ }^{31}$ were Warren and Brandeis who referred to the right to privacy as the individual's right "to be let alone," 32 a phrase borrowed from Judge Thomas Cooley's Law of Torts. ${ }^{33}$ Cooley referred to the right to privacy as a person's right of complete immunity. The phrase "right to be let alone" is related to the idea of liberty, in the sense that an individual has the liberty to choose whether or not to permit the publication of facts about themselves. The right encompasses an individual right of exclusivity in private life free from any interferences effected either directly or indirectly. ${ }^{34}$ According to Warren and Brandeis, the underlying principle of privacy was "that of inviolate personality". ${ }^{35}$ The value of privacy, as they noted, was not found in the right to take the profits arising from publication, but in the peace of mind or the relief afforded by the ability to prevent any publication. In other words, the end product of the invasion of privacy is rooted in mental pain and distress far greater than could be inflicted by mere bodily injury. ${ }^{36}$

The right "to be let alone" as referred to by Warren and Brandeis was interpreted by Justice Fortas in Time Inc v Hill as the right "to live one's life as one chooses, free from assault, intrusion or invasion except as they can be

\footnotetext{
${ }^{30}$ Clayton and Tomlinson The Law of Human Rights, above n 3, at 1007.

${ }^{31}$ Historically the notion of privacy has existed at least since 1361, when the Justices of the Peace Act in England provided for the arrest of peeping toms and eavesdroppers. Then, in Entick v Carrington (1765) St Trials 1029, Lord Camden, striking down a warrant to enter a house and seize papers wrote, "We can safely say there is no law in this country to justify the defendants in what they have done; if there was, it would destroy all the comforts of society, for papers are often the dearest property any man can have."

${ }^{32}$ Warren and Brandeis, above $\mathrm{n} 27$, at 195.

${ }^{33}$ Thomas M Cooley A Treatise on the Law of Torts $\left(2^{\text {nd }}\right.$ ed, Callaghan, Chicago, 1888).

${ }^{34} \mathrm{As}$ discussed in Warren and Brandeis, above $\mathrm{n} 27$, at 195.

${ }^{35}$ At 205.

${ }^{36}$ At 196.
} 
justified by the clear needs of community living under a government of law". ${ }^{37}$ In particular, the right "to be let alone" refers to the privilege of planning and shaping one's own life to do anything one pleases or to go anywhere one desires. Thus, if privacy is the right "to be let alone" it makes the concept so broad and vague as to embrace all aspects of one's life free from any interference.

It is definitely true that loss of privacy results from a situation of not being left alone, but there are instances where a state of not being left alone is not a loss of privacy; for example scratching someone on the face which is clearly the situation of not letting a person alone, may have nothing to do with loss of privacy. Similarly, privacy is not lost when A hits B's head. A is not letting B alone, and B's right to privacy is not lost, although A may be liable for assault and battery. However, the situation would be different if A entered B's house and hit B. This is clearly a situation of not letting someone alone, and therefore, of a loss of privacy.

On the other hand, Dean Prosser ${ }^{38}$ believes that Warren and Brandeis are wrong and that their analysis of the tort of privacy is mistaken because privacy is not an independent value but rather a collection of interests in reputation, peace of mind and intangible property. ${ }^{39}$ He states that what is involved "is not one tort, but a complex of four." 40 The "four distinct torts" are:

(1) Intrusion into seclusion, solitude, or private affairs. The type of interest protected is the interest in freedom from mental distress;

(2) Publication of private facts in which the tort protects the interest in reputation;

\footnotetext{
${ }^{37}$ Time Inc v Hill [1967] 385 US 374, at 413.

${ }^{38}$ William L Prosser "Privacy" (1960) 48(3) California Law Rev 383

${ }^{39}$ At 384.

${ }^{40}$ At 389.
} 
(3) Casting a person in a "false light". It protects the interest in reputation;

(4) Appropriation of personality or likeness. The tort protects the proprietary interest in name and likeness.

Prosser's analysis of the privacy cases is remarkable for two reasons: the first that there is not a single tort of invasion of privacy, but rather "four distinct torts"; the second, that there is no distinctive single value or interest which these "distinct torts" protect, and that, in fact, they protect three different interests, not one of which can properly be denominated an interest in privacy. ${ }^{41}$ For Bloustein, none of the four categories of distinct tort protects privacy specifically; rather it transforms into a form of defamation, infliction of mental distress and misappropriation. ${ }^{42}$ If Dean Prosser is correct, there is no "new tort" of invasion of privacy, there are rather only new ways of viewing "old torts". ${ }^{43}$ Moreover, the interest in privacy is not an independent one, rather it is a composition of values that society holds in preserving mental calmness, reputation and dignity as well as other intangible forms of property. $^{44}$

Powers $^{45}$ view on how privacy is understood and defined is noteworthy. According to him, some theorists see privacy within a conceptual point of view and develop a conception of privacy in the context of legal theory. ${ }^{46}$ Through this method, desirable protection could be provided in the context of a particular legal jurisdiction. ${ }^{47}$ Others focus on interpretative issues, such as the legitimacy of a judicial development of fundamental rights to privacy when no explicit reference to it is found within the language or history of the

\footnotetext{
${ }^{41}$ As indicated by Bloustein "Privacy as an Aspect of Human Dignity" above ch 1, n 1, at 966. ${ }^{42}$ At 966.

${ }^{43}$ At 966.

${ }^{44}$ Prosser, above n 38, as highlighted by Bloustein, above ch 1, n 1, at 962, 966.

${ }^{45}$ Madison Powers "A Cognitive Access Definition of Privacy" (1996) 15 Law and Philosophy 369.

${ }^{46}$ At 369.

${ }^{47}$ Gavison, above $\mathrm{n} 28$, at 423 . According to Gavison, privacy must be a concept useful in legal context, that enable people to identify those occasions which call for legal protection because the law does not interfere to protect against every undesirable event.
} 
constitution of a jurisdiction. ${ }^{48}$ This occurs when the right to privacy is not specifically given a guarantee in the Constitution. Malaysia is such an example. Purely conceptual inquiries, by contrast, concentrate on the search for a privacy definition that can be defended on general philosophical grounds and used to make sense of the myriad of debates arising within any political or legal tradition. ${ }^{49}$

Having discussed privacy generally, two important questions prevail. The first relates to the status of the term: is privacy a situation, a right, a claim, a form of control, or a value? The second relates to the characteristic of privacy: is it related to information, to autonomy, to personal identity, to physical access? ${ }^{50}$ These questions require further discussion of the concept of privacy to determine whether privacy is best understood as a description of (1) a capacity for control or (2) a state or condition. The discussion is important because a legal conception of privacy must be built on a solid foundation so to exclude unnecessary acts being regarded as breaches of privacy.

The following sections discuss privacy authors' support for the control definition of privacy on one hand, and the rejection of the control definition on the other hand.

\section{A Support for the control definition}

Many commentators regard privacy as control over access to oneself; either to information about oneself, to one's physical self or to both. The protection of personal information and protection against intrusion are discussed by

\footnotetext{
${ }^{48}$ John Hart Ely "The Wages of Crying Wolf: A Comment on Roe v Wade" (1973) 82 Yale LJ 920; see also Powers, above n 45, at 370.

${ }^{49}$ Powers, above $\mathrm{n} 45$, at 370 .

${ }^{50}$ Gavison, above $\mathrm{n} 28$, at 424 .
} 
scholars including Schoeman, ${ }^{51}$ Parker, ${ }^{52}$ Fried, ${ }^{53}$ Miller, ${ }^{54}$ Beardsley, ${ }^{55}$ Solove,${ }^{56}$ Wacks, ${ }^{57}$ Altman ${ }^{58}$ and Gerety. ${ }^{59}$ All perceived privacy as a form of control.

The word "control" suggests that a person has the power to influence or the ability to manage or to restrain the actions, occurrence of events or behaviour. If control is lost, or the subject of the control over the self disappears, privacy is said to have been invaded.

Privacy has been identified as the measure of control an individual has over (a) information; (b) intimacies of personal identity; or (c) sensory access to the person. ${ }^{60}$ In other words, privacy as a form of control equates with an individual's control over access to some aspects of the self. A clear example of the concept of privacy as a form of control is Westin's definition which considers information privacy as "the claim of individuals, groups, or institutions to determine for themselves, when, how and to what extent information about them is communicated to others." ${ }^{, 61}$ In other words, Westin perceived privacy as a claim to control information rather than a state of control itself.

\footnotetext{
${ }^{51}$ Ferdinand Schoeman "Privacy: Philosophical Dimensions" (1984) 21(3) American Philosophical Quarterly 199. The author discussed privacy philosophically from intellectual and historical context.

${ }^{52}$ Richard B Parker “A Definition of Privacy” (1974) 27 Rutgers Law Rev 275.

${ }^{53}$ Charles Fried "Privacy" (1968) 77(3) Yale LJ 475.

${ }^{54}$ Arthur R Miller The assault on privacy: computers, data banks, and dossiers (University of Michigan Press, Ann Arbor, 1971).

${ }^{55}$ Elizabeth Beardsley "Privacy: Autonomy and Selective Disclosure" in (eds) JR Pennock and JW Chapmans Privacy and Personality (Transaction Publishers, USA, 1971).

${ }^{56}$ Solove, above $\mathrm{n} 1$.

${ }^{57}$ Raymond Wacks "The Poverty of Privacy" (1980) 96 LQR 73.

${ }^{58}$ Irwin Altman "Privacy - A Conceptual Analysis" (1976) 8 Environment and Behaviour 7.

${ }^{59}$ Tom Gerety "Redifining Privacy" (1977) 12 Harvard Civil Rights-Civil Liberties Law Rev 233.

${ }^{60}$ Schoeman, above $\mathrm{n} 51$ at 199.

${ }^{61}$ AF Westin Privacy and Freedom (Bodley Head Ltd, London, 1970) at 7.
} 
The "control" definition of privacy has been adopted by other writers. Fried defines privacy as control over information. For him, privacy is not simply an absence of information about people in the minds of others; rather it is the control people have over their information. ${ }^{62}$ Control is not simply over the quantity of information; it also includes quality of knowledge. ${ }^{63}$ Thus, if people know general facts, this might not invade privacy, conversely if details are known, this may require protection of privacy. Fried provides an interesting example where if $\mathrm{A}$, a casual friend of $\mathrm{B}$, not only knowing that $\mathrm{B}$ is sick, but knowing also the nature of the illness, and reveals these details, such revelation violates B's privacy. Fried concludes that a person should be granted power to control aspects of their environment. This can be done by giving the person a legal title to control that which is the least open to question and argument. ${ }^{64}$

Another concept of privacy identifies it with control over information about oneself. Beardsley equates the right to privacy with the right to selective disclosure and explains the latter as the right to decide when and how much information may be made known to others. ${ }^{65}$ In other words, a person has a right to decide what, when and to whom his or her information may be revealed. Beardsley argues that selective disclosure constitutes the conceptual core of privacy. ${ }^{66}$ While Beardsley maintains the element of choice or selection of information, Miller stresses the "ability to control", and asserts that "the basic attribute of an effective right of privacy is the individual's ability to control the circulation of information relating to him". ${ }^{67}$ Thus, Miller is in agreement with Fried, and supports privacy as the state of control one has over the circulation of personal information as opposed to a claim to control. ${ }^{68}$

\footnotetext{
${ }^{62}$ Fried, above n 53, at 482 .

${ }^{63}$ At 483 .

${ }^{64}$ At 493

${ }^{65}$ Beardsley, above n 55, at 65 .

${ }^{66}$ At 70.

${ }^{67}$ Miller, above $\mathrm{n} 1$.

${ }^{68}$ At 25.
} 
Wacks approaches privacy as an interest claimed by individuals to withhold certain information by virtue of its privacy or sensitivity. ${ }^{69}$ Here, the private and sensitive characteristics of information make it clear that such information will cause an invasion of privacy only if it is known to others. This concept of privacy supports the need to defend secret and personal information that no one wishes to make public.

According to Parker, privacy is "control over who senses us". ${ }^{70} \mathrm{He}$ defends the view that "privacy is control over when and by whom the various parts of us can be sensed by others". The word "sensed" here refers to the five senses of sight, hearing, touch, smell and taste. Though privacy is often used as a means of controlling circulation of information about people, yet privacy itself is control over who can sense them. ${ }^{71}$ While Fried ${ }^{72}$ views privacy as the control a person has over information, Parker stresses the control over a person's physical parts that can be sensed by others. However, I suggest that to confine the definition of privacy to Parker's notion reduces the flexibility to deal with emerging privacy problems. ${ }^{73}$

A further control concept of privacy that has gained increasing support identifies it with control over access to the self. Altman ${ }^{74}$ attempts to defend the idea that privacy consists of a boundary control process whereby people can make themselves accessible to others or close themselves off. ${ }^{75}$ Clearly, the idea revolves around the power to exercise complete control one has over personal relationships and is not concerned with control over information. Indeed, where other scholars focus on the informational aspect of privacy,

\footnotetext{
${ }^{69}$ Wacks, above n 57.

${ }^{70}$ Parker, above n 52, at 280.

${ }^{71}$ At 281.

${ }^{72}$ Fried, above n 53 .

${ }^{73} \mathrm{I}$ am in agreement with Solove who rejected certain control conception of privacy. See Solove, above $\mathrm{n} 1$, at 1093 .

${ }^{74}$ Altman, above n 58; see also Irwin Altman "Privacy Regulation: Culturally Universal or Culturally Specific?” (1977) 33 Journal of Social Issues 66.

${ }^{75}$ Altman, above n 58.
} 
Altman perceives privacy as control over other privacy aspects, which is an intrusion on the self.

To sum up, the proponents of control definition perceive privacy as a form of control over personal information as well as to the self or physical parts of a person. It is understood, therefore, a privacy breach is said to have occurred when a person loses control over either one or both aspects.

\section{B Criticisms of control definition of privacy}

This control definition of privacy is criticised by some writers. ${ }^{76}$ They point out that control is not a prerequisite, and even that control can be exercised without privacy. Examples given by Fried shows that control is neither a necessary nor sufficient condition of privacy. The first instance is that of a man inadvertently cast on a desert island. He has lost control over who has information about him but he nonetheless retains his privacy by virtue of being alone on the desert island. Another instance is that of a man who freely chooses to divulge personal information. Although he has control over access, by disclosing it to certain people of his choice, he lacks privacy because others have gained information about him. Schoeman observed, therefore, that control is not a sufficient condition for the existence of informational privacy: ${ }^{77}$

One difficulty with regarding privacy as a claim or entitlement to determine what information about oneself is to be available to others is that it begs the question about the moral status of privacy. It presumes

\footnotetext{
${ }^{76}$ Those who criticised the control definition of privacy include Gavison, above $\mathrm{n} 28$, Allen, above n 1; see also WA Parent "A New Definition of Privacy for the Law" (1983) 2(3) Law and Philosophy 305, and Schoeman, above n 51.

${ }^{77}$ Ferdinand Schoeman "Privacy: Philosophical Dimensions of the Literature", in Philosophical Dimensions of Privacy: An Anthology (Cambridge University Press, Cambridge, 1984).
} 
privacy is something to be protected at the discretion of the individual to whom the information relates.

Miller's theory of control focuses on information which excludes aspects of privacy that are not informational though he fails to define types of information over which an individual has control. ${ }^{78}$ The term "information relating to him" is too broad to cover all types of general information. Some information does not require controlled circulation, and some is specific and detailed and circulation would amount to an invasion of privacy. Solove states: ${ }^{79}$

the privacy as control over information theory at most says that we protect as private all information over which individuals want to retain control. Privacy, however, is not simply a matter of individual prerogative; it is also an issue of what society deems appropriate to protect.

Solove comments that Parker's "control over who senses us" would make most interpersonal contact in society a privacy invasion because it brings unwanted access to the self. In daily activities, we are frequently seen and heard by others without perceiving it as even the slightest invasion of privacy. ${ }^{80}$

Parent ${ }^{81}$ argues that the effort to conceive of privacy as a form of control is totally wrong. The right to control as he suggests, whether it be over sexual matters, personal information, or access to oneself should be seen not as constitutive of the right to privacy but as an integral element of the right to liberty. Whenever one person or group of persons tries to deprive another of control over some aspect of life, this should be recognised as attempted

\footnotetext{
${ }^{78}$ Miller, above $\mathrm{n} 1$.

${ }^{79}$ Solove, above $\mathrm{n} 1$ at 1111 .

${ }^{80}$ At 1111 .

${ }^{81}$ Parent, above n 76.
} 
coercion and should be evaluated as such, under the general concept of freedom-limiting action. ${ }^{82}$

Gavison's rejection of the control definition makes it possible to describe changes in that condition which count as losses of privacy. ${ }^{83}$ For her, a voluntary disclosure of information is not a loss of privacy; rather it is an exercise of control. However, a voluntary disclosure may constitute a loss of privacy because the disclosure has prevented the owner of the information from stopping others from disseminating the information. For example, if $\mathrm{A}$, a married man tells B about his affairs with a famous singer who is not his wife, A is exercising his power of control over his personal information. At this stage he does not suffer any loss of privacy. But, if B informs A's friend about the affairs and the friend passes the news to a colleague, it is a great invasion of A's privacy.

According to Gavison, ${ }^{84}$ the need for privacy has coherence in three different contexts. There must be a neutral concept so that a loss of privacy can be identified; it must also have coherence as a value, so that an identifiable loss of privacy can be considered undesirable in certain contexts and thus worthy of legal protection; finally it must have coherence in a legal context since it is not possible to provide legal protection against all undesirable events. The three different contexts simplified as loss of privacy, invasions of privacy, and actionable violations of privacy are linked to the concept of privacy and its promotion of liberty, autonomy, selfhood and human relations. ${ }^{85}$

Gavison argues further that "control" suggests that an important aspect of privacy is the ability to choose it and ensure that the choice is respected. Whatever the choices are, they are consistent with enjoyment of control.

\footnotetext{
${ }^{82}$ At 328.

${ }^{83}$ Gavison, above n 28, at 427 .

${ }^{84}$ Gavison, above n 28 .

${ }^{85}$ At 423 .
} 
Defining privacy in terms of control, therefore, relates it to the power to make certain choices rather than how the power is exercised. ${ }^{86}$

There are two reasons why Gavison rejects the control form of privacy. In a weak situation of control, she argues that control is not sufficient as a description of privacy, for a person only has the control of disclosing or withholding information, but others may know the information through other means. ${ }^{87}$ Thus, if $\mathrm{X}$ who suffers from HIV wants to keep the information to himself, he has absolute control by not communicating it to others, but he cannot prevent others having access to that information if through his carelessness, $\mathrm{Y}$ discovers that his patient or medication card classifies $\mathrm{X}$ as HIV positive. On the other hand, through a stronger sense of control, loss of privacy is possible when there is only a threat of such loss. ${ }^{88}$ For example, if a person voluntarily announces his love affairs with someone and no one is interested, his privacy may be lost if the information is conveyed to others against his wishes, despite the fact that he is only exercising his power to control the disclosure of the information.

The unsuitability of the control definition for privacy is also discussed by Moreham. ${ }^{89}$ According to her, control over access to a person can be lost even though no access is actually gained. As Gavison points out, ${ }^{90}$ a strong sense of control may be a sign of loss of privacy when in fact there is only a threat of such a loss. Thus, by employing the control definition, there is a failure to distinguish between situations where there is a risk of unwanted access, and those where unwanted access has in fact been obtained. ${ }^{91}$ The following

\footnotetext{
${ }^{86}$ At 423.

${ }^{87}$ At 427.

${ }^{88}$ At 427 .

${ }^{89}$ NA Moreham "Privacy in the Common Law: A Doctrinal and Theoretical Analysis" (2005) 121 LQR 628 ["Privacy in the Common Law"].

${ }^{90}$ Gavison, above n 46 at 427, Discussed also by Moreham, above n 89, at 638 .

${ }^{91}$ Moreham, above n 89 at 638. Moreham gave an example of an internet hacker to illustrate this point. See also Hunt "Conceptualizing Privacy and Elucidating its Importance", above n 8 at 184-187. The author referred to Moreham. According to Hunt, there are three significant
} 
example may be useful. If an employer has installed a device in his employee's computer to monitor and track all personal activities, the employee has lost control over his activities via computer, and has, therefore, lost his privacy, even though it is merely an installation because the employer has never activated the device. Moreover, the difficulty of the control definition is found in the exercise of control over information itself because the disclosure of personal information involves a simultaneous exercise and relinquishment of control. Thus, to maintain privacy within the control definition is to refrain from disclosing information to anyone. ${ }^{92}$

The criticism of the control conception of privacy leads to a formulation of another description of privacy: a state or condition of limited access to one or more aspects of a person.

\section{Privacy as a state or condition}

The discussion above argues that privacy cannot be described as a form of control because loss of that control does not necessarily result in a loss of privacy. So, if privacy is not about control, how is it to be described?

The interest in privacy relates to the concern about conditions of life, particularly the extent to which persons are known to others, physical access others have to them, and the degree to which they are the subject of others' attention. ${ }^{93}$ Hence, there are scholars who conceive of privacy as a state or condition, not a form of control or a right.

problems in conceiving privacy as control over information. First, it is too narrow and too restricted to confine the control to information only because privacy can still be invaded without the information being communicated. Second, control-based definition is ambiguous as it is used by different commentators. Third, the possibility of over-breadth because of failure to identify with precision the types of information falling within a control-based conception of privacy.

${ }^{92}$ At 638 .

${ }^{93}$ Gavison, above n 28, at 423 . 
Gross suggests that privacy is a state of affairs: the condition of life in which acquaintance with persons, or with affairs of their lives is limited. ${ }^{94}$ Common practices in society preserve such a condition; for example, curtains, bedroom doors, locked cabinets, and clothes indicate the concern for privacy. Thus, concern for privacy is the concern for a state of affairs, not merely a claim for privacy as it is understood from Westin's definition. ${ }^{95}$ Gross further emphasises essential features of privacy such as physical solitude, physical exclusiveness, and autonomy. ${ }^{96}$ These terms designate privacy as a state of affairs and cannot be referred as claim or control.

Parent proposes privacy as "the condition of not having undocumented personal information about oneself known by others". ${ }^{97}$ Personal information is understood to consist of facts about a person which he or she at any time does not want widely known. Most persons in a given society choose not to reveal about themselves (except perhaps to close friends or family) facts about which they are acutely sensitive even though some people do not care if these same facts about themselves are widely known. ${ }^{98}$

The above discussion suggests that privacy is actually a situation of being inaccessible to others and is more than a control one has over personal information or physical being. That is to say, the control definition of privacy implies an objective control an individual has over privacy aspects, but, privacy as a condition or a state, on the other hand, encompasses situations beyond a claim or a control.

\footnotetext{
${ }^{94}$ Hyman Gross “The concept of privacy" (1967)(42) NYUL Rev 34 at 37-38.

${ }^{95}$ Westin has defined privacy as the "claim of individuals, groups or institutions to determine for themselves when, how and to what extent information about them is communicated to others". See above n 61, at 7.

${ }^{96}$ Gross, above $\mathrm{n} 93$.

${ }^{97}$ Parent, above $\mathrm{n} 76$ at 306.

${ }^{98}$ At 307. Thus, Parent excludes knowledge of documented personal information from his definition of privacy. Information of public records such as in newspapers, court proceedings and government archives will not attract any liability for invasion of privacy because they are documented form of information.
} 


\section{Inaccessibility}

Privacy as a state of affairs is a condition of limited access to one or more aspects of a person. Privacy is thus a consequence of inaccessibility, and loss of privacy is loss of inaccessibility. ${ }^{99}$

Accessibility and inaccessibility are two components of privacy. Moreham defines privacy as the state of "desired inaccess", or as "freedom from unwanted access". ${ }^{100}$ Thus, if a person is seen, heard, touched or found out only to the extent that he or she wants to be seen, heard, touched or found out about, that person is said to be in a state of privacy. A person is "in private" if others respect his or her wishes to be free from outside access to his or her personal information. Thus, according to Moreham there are two aspects of a privacy definition - access and a desire not to be accessed. ${ }^{101}$

It is interesting to assess Moreham's element of "desire" in her definition of privacy. "Desire" connotes a strong feeling of wanting to have something or wishing for something to happen. ${ }^{102}$ According to her, the desire element recognises that self-disclosure is a breach of privacy only if the person concerned does not want it to occur. ${ }^{103}$ In my opinion, "desired inaccess" implies the element of choice that an individual has in relation to disclosure of personal statement or access to the self. For example, A has a choice of whether or not to tell the facts about her financial status to B, a close friend, but there are two implications as a result of A's choice. First, if A discloses them and $\mathrm{B}$ disseminates the information to another friend, $\mathrm{C}, \mathrm{A}$ 's privacy is invaded. Second, if A keeps the information to herself and has no desire to make it known to others, $\mathrm{A}$ is enjoying privacy.

\footnotetext{
${ }^{99}$ Powers, above n 45 at 375 .

${ }^{100}$ Moreham, above n 89 at 633 .

${ }^{101}$ At 636.

${ }^{102}$ The Oxford Dictionaries Pro < http://english.oxforddictionaries.com/definition/desire $>$

${ }^{103}$ Moreham, above n 89, at 637.
} 
What is then meant by "access"? In Moreham's view access means perceiving a person with one's senses (ie seeing, hearing, touching, smelling or tasting), obtaining physical proximity to him or her, and obtaining information about him or her. ${ }^{104}$ Thus photographing a person, installing a CCTV in a house, recording a person's activity in private places are examples of access which if unwanted, are clearly breaches of privacy.

While Moreham focusses on the inaccessibility and desire to reveal or conceal the state or condition of a person, Gavison views privacy in relation to concept and value. Concept identifies loss of privacy neutrally and descriptively, whereas value refers to privacy in terms of reasons for its protection.

Gavison ${ }^{105}$ and Garrett ${ }^{106}$ defend the definition of privacy which equates it with the limitation of access to the self. This definition is in one way broader than Altman's who argues that privacy consists of a boundary control process whereby people can choose to make themselves accessible to others or close themselves off since exercising autonomy is one way of ensuring distance. Thus, on the basis of this theory, every citizen has the right to keep their affairs to themselves and to decide to what extent the same shall be the subject of public scrutiny and discussion.

\section{E Elements of accessibility}

If privacy is a consequence of inaccessibility, there must be requirements for such a state of inaccessibility. I believe that Gavison's description of the state of privacy is the most satisfactory one. She defines privacy as "a limitation of others' access to an individual" ${ }^{107}$. It is a situation whereby an individual

\footnotetext{
${ }^{104}$ At 640 .

${ }^{105}$ Gavison, above n 28 at 428 .

${ }^{106}$ Roland Garrett "The Nature of Privacy" (1974) 18 Philosophy Today 274.

${ }^{107}$ Gavison, above n 28, at 428 .
} 
enjoys perfect privacy when that individual is completely inaccessible to others. A loss of privacy occurs when others obtain information about an individual, pay attention to, or gain access to that individual. ${ }^{108}$

The limited access conception of privacy is a state of being protected from unwanted access by others either by physical access, personal information or attention. Gavison argues that privacy as a broad concept contains three elements: secrecy, anonymity and solitude. In her words: ${ }^{109}$

secrecy, anonymity and solitude are shorthand for the extent to which an individual is known, the extent to which an individual is the subject of attention and the extent to which others have physical access to an individual.

The concept of privacy as "limited access" to the self has been recognised as the individual's desire for concealment and for being apart from others. ${ }^{110}$ This concept has been widely discussed in Gavison's theory of access. These categories of access are distinct and independent, but interrelated. ${ }^{111}$

Secrecy of certain matters in relation to privacy is the non-disclosure of concealed information. According to Posner: ${ }^{112}$

The word "privacy" seems to embrace at least two distinct interests. One is the interest in being left alone - the interest that is invaded by the unwanted telephone solicitation, the noisy sound truck, the music in elevators, being jostled in the street, or even an obscene theatre billboard or shouted obscenity...The other privacy interest, concealment of

\footnotetext{
108 At 428

${ }^{109}$ At 428

${ }^{110}$ Solove, above $\mathrm{n} 1$ at 1102 .

${ }^{111}$ Gavison, above n 46.

112 Richard A Posner The Economics of Justice (Harvard University Press, Cambridge, 1981) at $272-273$.
} 
information, is invaded whenever private information is obtained against the wishes of the person to whom the information pertains.

When information about an individual is known, that individual loses privacy. That is what Gavison means when she refers privacy as secrecy. According to her, secrecy is largely connected with information privacy, where a loss of privacy occurs when others obtain information about an individual. Unless this information is considered at least partly determinative of the degree of privacy an individual has, these cases cannot be described as involving losses of privacy. ${ }^{113}$

However, there are scholars who argue that there is no loss of privacy when information about an individual becomes known. Gerety ${ }^{114}$ argues that information is part of privacy only if it is "private" and related to intimacy, identity and autonomy. Information which is general and not private when publicised, does not entail loss of privacy. ${ }^{115}$ In this connection, Parker advocates that there are situations when loss of control over information does not mean loss of privacy. An example given was an examination in which it was revealed the student did not study. ${ }^{116}$

While most theorists recognise the disclosure of certain secrets to be a violation of privacy, many commonly recognise privacy invasions do not involve the loss of secrecy. Solove comments that to view secrecy as a common denominator of privacy makes the definition privacy too narrow. ${ }^{117}$ Linking privacy with secrecy results in a failure to recognise what information individuals want to keep private from some people but not from others. ${ }^{118}$ For

\footnotetext{
${ }^{113}$ Gavison, above n 28, at 429.

${ }^{114}$ Gerety, above n 59.

${ }^{115}$ At 281 .

${ }^{116}$ Parker, above $\mathrm{n} 52$, at 282 . According to him, the student whose ignorance is revealed by the examination has not lost any privacy, although he may choose not to let the examiner see his paper, an exercise of his privacy, in order not to have his ignorance revealed.

117 Solove, above n 1, at 1109.

${ }^{118}$ At 1108.
} 
example, if an employee criticises a policy adopted by the manager at his workplace to a fellow employee, he does not want his criticism known by the manager, but does not care if it is known to other employees.

The second category of access highlighted by Gavison is anonymity. Anonymity in relation to privacy is not an issue of not being identifiable by name, but rather of being the subject of attention. A person is said to lose privacy when he becomes the subject of attention. ${ }^{119}$ Though the person's name is not known, other facts may be known such as the place of living, work, hobbies and interests which can identify them or to make them recognisable to others. All facts taken together means that attention is paid to the person which amounts to an invasion of privacy. Discussion may involve loss of privacy by communicating information about a person, or by creating an interest in the person under discussion that may itself lead to more attention. This activity may in turn produce a further loss of privacy if new information is obtained. ${ }^{120}$

The last category of access is solitude in which individuals lose privacy when others gain physical access to them. Physical access connotes physical proximity that is close enough to touch or observe through normal use of the senses. ${ }^{121}$ In this sense, an intrusion on privacy takes place not because more information has been acquired or more attention has been drawn to the person, but that the individual's spatial needs have been diminished.

This concept of privacy as secrecy, anonymity and solitude is coherent because all are part of the same notion of accessibility and are related in many important ways. A good example is the psychiatrist who sits next to his patient and listens to him, and acquires information about the patient, pays

\footnotetext{
${ }^{119}$ Gavison, above n 28 at 432 .

${ }^{120}$ At 433 .

${ }^{121}$ At 433 .
} 
attention to him and has physical access to him. ${ }^{122}$ The example shows that all three elements may coexist in the same situation. However, none of the three elements is the necessary companion of the other two. This may be illustrated in a situation in which a person becomes the subject of attention. In this regard, information about the person is acquired and thus results in loss of privacy. Nonetheless, the information is obtained without involving physical proximity to the person.

Having discussed all the elements, their importance is acknowledged in determining privacy both from theoretical and practical legal perspectives. A law of privacy should address these aspects in providing protection from invasion.

\section{F Intrusion}

Gavison's theory of accessibility that relates to protection against intrusion is explained by the elements of anonymity and solitude. Although the concept of anonymity does not involve any physical touch, to become a continual subject of attention interferes with a person's privacy. For example, if a person is continually followed, stared at, listened to, and observed in any other way, that person's privacy is said to have been invaded.

In the intrusion of solitude, physical access has been obtained by others which constitutes an invasion of a person's privacy. For example, a stranger who gains access to a room to see a person undress or to record a video of that person having a shower, or access to a labour room to watch a woman giving birth are examples of intrusion upon seclusion and, therefore, breaches of privacy.

\footnotetext{
${ }^{122}$ At 434 .
} 
Moreham refers to this as physical inaccess, that is the absence of access to one's person (or to things closely associated with one's person such as one's house, clothes or wallet) either through the use of the senses or through unwanted physical proximity. For example, if A installs a CCTV in B's house and captures all B's activities, A is said to interfere with B's physical privacy. According to Moreham, these physical privacy interests are an integral part of the privacy concept. ${ }^{123}$

Allen ${ }^{124}$ claims that a person is physically inaccessible if she cannot be experienced through one of the five senses. According to her, a person is dispositionally inaccessible when her states of mind cannot be detected. States of mind include beliefs, desires and preferences. A person is informationally inaccessible when facts about her are unknown or unknowable. She further claims that "inaccessibility in one respect does not always entail privacy in other respects". ${ }^{125}$

A number of commentators ${ }^{126}$ recognise that a comprehensive definition of privacy must accommodate both physical and informational privacy interests. In other words, it must protect individuals against the unwanted watching, listening, touching etc as well as against the unwanted acquisition and dissemination of private information. ${ }^{127}$

In the context of this thesis, unwanted access to the self or the body implies the act of intruding upon a person's interest in privacy. "The self" implies wider coverage than "the body" to include an individual's personality, feelings, perspectives and thinking whereas "the body" refers to the physical manifestation of a person. In this relation, a physical intrusion occurs when

\footnotetext{
${ }^{123}$ Moreham, above n 89, at 649.

${ }^{124}$ Allen, above $\mathrm{n} 1$.

${ }^{125}$ At $16-17$.

${ }^{126}$ Moreham, above n 89 at 651. They includes Gerety above n 59, at 265 and Gavison, above n 28 , at 423

${ }^{127}$ At 651 .
} 
there is unwanted or undesired access to a person. Thus, a claim of invasion of privacy is maintained in this situation.

\section{Privacy and Private Matters in Islam}

Having discussed the concept and definition of privacy in the West, it is important to examine the same from Islamic perspective. Such a discussion is relevant to determine whether the basis for the concept of privacy in Islam is consistent with the Western concept.

In this part, the concept of privacy and private matters in Islam will be discussed and some Quranic verses are highlighted as the basis for the protection of privacy. The division between public and private spheres is examined to ascertain what is private to Muslims and therefore requires appropriate protection.

Privacy is very important in Islam and the right to privacy is one of the most precious freedoms, most comprehensive and respected of rights. ${ }^{128}$ In Islam, privacy and good manners in public contribute to the highest virtues, and are parts of a Muslim's duty. ${ }^{129}$

Although Muslim scholars' engagements with the Islamic notion of privacy is lacking compared with ideas and arguments of Western scholars on

\footnotetext{
${ }^{128}$ Berween M "The Fundamental Human Rights: An Islamic Perspective" (2002) 6(1) The International Journal of Human Rights 61 at 72, where the author described privacy as the eighth basic human right from an Islamic perspective. The right to privacy in Islam includes (1) the right for every individual to be left alone in their private life; (2) the right to be free from governmental surveillance and intrusion; (3) the right not to have an individual's private affairs made public without their permission; (4) the protection of persons, and places where they live from searches and seizures; (5) the protection of knowledge and thoughts from compulsory self-incrimination; and (6) the right to keep all personal information confidential. ${ }^{129}$ At 72
} 
privacy, ${ }^{130}$ there is, to a certain extent agreement among Western and Islamic jurists that the domestic sphere ought to be legally safeguarded because of the importance of domestic privacy. ${ }^{131}$ On this basis, it is essential to differentiate between the private and the public spheres as they relate to the protection of an individual's privacy.

Alshech's analysis of the Islamic references shows that the vast majority of Muslim scholars living between the seventh and the fifteenth centuries C.E. did not articulate any explicit notion of privacy. However, this fact did not prevent them from compiling laws relating to the protection of homes, bodies, private information, private affairs and peace of mind. ${ }^{132}$ In the early period of Islam, scholars viewed the private sphere as a realm within which a person and his family should be protected from public humiliation. Based on this view, people were allowed to conceal information about themselves, such as information about immoral behaviour, illegal acts and intimate body parts. Thus, Alshech believed that the early conception of privacy encompassed a limited set of freedoms and protections, and the sphere of privacy was relatively narrow in scope. ${ }^{133}$

Significantly after that period, the Islamic notion of privacy has developed beyond the limited realm of protecting one's reputation to include more general control of personal information and limited access to all personal matters. ${ }^{134}$ According to Alshech, the private sphere is defined by the desires of individuals, so that jurists make laws to safeguard those matters that a

\footnotetext{
${ }^{130}$ Eli Alshech "Do not Enter Houses Other than Your Own: The Evolution of the Notion of A Private Domestic Sphere in Early Sunni Islamic Thought" (2004) 11(3) 291, at 292 ["Do not Enter Houses Other than Your Own"].

${ }^{131}$ Eli Alshech "Out of Sight and Therefore Out of Mind: Early Sunni Islamic Modesty Regulations and the Creation of Spheres of Privacy" (2007) 66 (4) Journal of Near Eastern Studies 267.

${ }^{132}$ At 268

${ }^{133}$ At 268

${ }^{134}$ At 268.
} 
person would want to conceal from others. ${ }^{135}$ The expansion of the private spheres definition has not altered the ultimate aim of privacy in Islam, that is, a means of protecting and preserving other important values including a person's reputation, healthy social relations and household stability. ${ }^{136}$

In relation to public and private spheres in Islam, Kadivar cited three meanings of private given by Boruch: ${ }^{137}$

First, that which is personal or exclusive to the individual; second, that which one would rather keep concealed and protected from others; and third, that over which the individual should exercise exclusive authority and control.

Kadivar defined "private" as a situation when an issue is kept hidden and inaccessible to others, and falls exclusively within the decision-making authority of an individual. ${ }^{138}$ This definition suggests that people have an absolute choice to decide which part of them is accessible to others and which part may be shared. One's private wishes, desires, hopes and most of one's personal memories, therefore, may fall into this sphere. Privacy is the sole prerogative of the individual, and others may not decide for or even offer advice regarding matters in the private sphere. ${ }^{139}$

According to Sharia standards, the prima facie status of every matter is private; the assumption is that all matters belong to the private domain unless

\footnotetext{
${ }^{135}$ At 268 .

${ }^{136}$ At 269.

${ }^{137}$ Mohsen Kadivar “An Introduction to the Public and Private Debate in Islam" (2003) 70(3) Social Research 659, at 661. The author referred to RF Boruch "Privacy of Individuals in Social Research: Confidentiality" in The International Encyclopedia of the Social and Behavioural Sciences (Elsevier Science, Oxford, 2001).

${ }^{138}$ Kadivar, above n 137 at 661.

${ }^{139}$ At 661 .The author gave examples of private matters fall in private sphere, including wealth and property, housing and occupation, religion and ideology, body and clothing, political subscriptions and social affiliations.
} 
proven otherwise. ${ }^{140}$ Individuals are entitled to decide their affairs themselves, and any interference requires proof that such issues belong to public concern. This principle implies that no one has the right to interfere in the affairs of an individual without specific permission. ${ }^{141}$

On the other hand, in the public sphere in principle, nothing is kept secret from citizens: the management, improvement and alteration of the public sphere are the prerogative of the citizenry. ${ }^{142}$ In other words, the public domain is the sphere of influence for governmental authority and jointly owned by all citizens. By analogy, all information in the public sphere is placed in a transparent container whose contents are in everyone's plain view. $^{143}$

In accordance with the two criteria of public and private spheres, Islamic jurisprudence has fully acknowledged the sanctity of the private domain. For example, in the Holy Quran, it is stated very clearly that an individual's privacy is guaranteed and no one should invade it without permission: ${ }^{144}$

O ye who believe! Enter not houses other than your own, until ye have asked permission and saluted those in them: that is best for you, in order that you may heed (what is seemly.) If ye find no one in the house, enter not until permission is given to you: if you are asked to go back, go back: that makes for greater purity for yourselves: and Allah knows well all that ye do.

\footnotetext{
${ }^{140}$ At 663 .

${ }^{141}$ At 663 .

${ }^{142}$ At 662 .

${ }^{143}$ At 662 .

${ }^{144}$ Abdullah Yusuf Ali The Holy Quran: Text, Translation and Commentary (Amana Corporation, USA, 1989) [The Holy Quran]. See The Holy Quran (An-Nur 24:27-28). See also (Al-Baqarah 2:189) "They ask thee concerning the New Moons. Say: They are but signs to mark fixed periods of time in (the affairs of men), and for Pilgrimage. It is no virtue if ye enter your houses from the back: It is virtue ye fear Allah. Enter houses through proper doors: and fear Allah that ye may prosper."
} 
There are a number of verses in the Holy Quran stressing the sanctity of home and personal life, and the importance of the human right to privacy. The Quran stipulates clear commandments of not entering into the house of others unless permission is manifestly given. And whenever a person has permission to enter a house, it is important to enter properly. ${ }^{145}$

Hayat stresses ${ }^{146}$ that Islam orders that no one inquire into the private matters of others, and strictly prohibits prying into these matters. If someone happens to come across private information, further disclosure of that information is not permitted. Any information about an individual should not be discussed or revealed in public whether or not it is true, without the consent of the person concerned. Managing the affairs of the private domain is the exclusive right of the individual. ${ }^{147}$ In contrast, there is no protection of privacy for the publication of private information which is already in the public domain.

In the Hadith, ${ }^{148}$ the Prophet Muhammad (pbuh) has reported that a person who attacks an intruder to prevent him from spying on his private home is not liable for punishment for the attack. The Hadith implies that the act is justified

\footnotetext{
${ }^{145}$ The Holy Quran. See also, Alschech "Do not Enter Houses Other than Your Own”, above n 130.

${ }^{146}$ MA Hayat "Privacy and Islam: From the Quran to Data Protection in Pakistan" (2007) 16

(2) Information and Communications Technology Law 137.

${ }^{147}$ At 137-138. See also The Holy Quran, above n 144 (Al-Hujuraat 49:12) "O ye who believe! Avoid suspicion as much (as possible) for suspicion in some cases in a sin: And spy not on each other, nor speak ill of each other behind their backs. Would any of you like to eat the flesh of his dead brother? Nay, ye would abhor it, but fear Allah: for Allah is OftReturning, Most Merciful." For further discussion of the concept of a private domestic sphere; see also Alshech "Out of Sight and Therefore Out of Mind", above n 130.

${ }^{148}$ The Hadith is the record of the exclusive sayings of Prophet Muhammad (pbuh). The sayings and conduct of Prophet Muhammad (pbuh) constitute the Sunnah. The Hadith has come to supplement the Holy Quran as a source of the Islamic religious law. The Hadith is the second pillar after the Quran upon which every Muslim rests his faith. See Mohammad Hashim Kamali Principles of Islamic Jurisprudence (Cambridge, UK, Islamic Texts Society, 2003), at 49.
} 
in protecting the sanctity of a private place. It is narrated from Abu Hurairah that the Prophet said: ${ }^{149}$

He who looked at the inside of person's house without his permission and his eyes were gouged, has no right to blood money nor punishment over them.

Preserving one's chastity and modesty is also an important aspect of privacy protection in Islam. The teaching places great emphasis on dress for men and women in order to protect their dignity and honour and safeguard privacy. However, a greater amount of privacy is required for women than men. The Holy Quran states: ${ }^{150}$

Say to the believing men that they should lower their gaze and guard their modesty that will make for greater purity for them: and Allah is well acquainted with all that they do.

And say to the believing women that they should lower their gaze and guard their modesty, that they should not display their beauty and ornaments except what (must ordinarily) appear thereof, that they should draw their veils over their bosoms and not display their beauty except to their husbands, their fathers, their husbands' fathers, their sons, their husbands' sons, their brothers or their brothers' sons, or their sisters' sons, or their women, or the slaves whom their right hands possess, or male servants free of physical needs, or small children who have no sense of the shame of sex and that they should not strike their feet in order to draw attention to their hidden ornaments. And $\mathrm{O}$ ye believers! Turn ye all together towards Allah, that ye may attain bliss.

${ }^{149}$ Ibn Qayyim al-Jawziyyah Turuq al-hukmiyyah translated by Ala'eddin Kharoffa (International Law Book Services, Kuala Lumpur, 2000). See also Zainal Amin Ayub and Zuryati Mohamed Yusoff "Leave me Alone!: Syariah v Civil Law" [2007] MLJ xcix.

${ }^{150}$ The Holy Quran, above n 144, (An Nur 24: 30-31). 
The importance of women's attire also relates to the image of the female Muslim so that they are easily recognised and protected from being improperly approached by men. The Holy Quran states: ${ }^{151}$

O Prophet! Tell thy wives and daughters and the believing women, that they should cast their outer garments over their persons (when abroad): that is most convenient, that they should be known (as such) and not molested. And Allah is OftForgiving, Most Merciful.

According to Berween, ${ }^{152}$ although the right to privacy is fundamental in Islam, it is not absolute. If there is a compelling reason warranting the violation of privacy, the government has the right to intervene, but no deprivation of the right should occur without due process of law. ${ }^{153}$ This is in line with the protection of privacy upheld in human rights documents where exceptions to the right are clearly emphasised to highlight any limitations of the right. ${ }^{154}$ In this regard, Hayat views privacy not as an individual or religious concern but rather the right of the individual to be respected by the state and government. One of the companions of the Holy Prophet reports- ${ }^{155}$

Hadrat Umar bin Khattab, the second caliph, was roaming in the city one night when he heard shouting and cursing coming from a residence; he then peeked over the perimeter and started admonishing the man: 'You, the sinner, do you think that God will ignore your sins, as you're sinning against him?' The man replied: 'Woe, commander of the

\footnotetext{
${ }^{151}$ The Holy Quran, above n 144, (Al Ahzab 33:59).

${ }^{152}$ Berween, above n 128.

${ }^{153}$ At 73.

${ }^{154}$ For example art $8(2)$ of the ECHR provides that "There shall be no interference by a public authority with the exercise of this right except such as is in accordance with the law and are necessary is necessary in a democratic society in the interests of national security, public safety or the economic well-being of the country, for the prevention of disorder or crime, for the protection of health or morals, or for the protection of the rights and freedoms of others".

${ }^{155}$ As discussed in Hayat, above n 146, at 140-141.
} 
faithful, do not rush to judgment; if I sinned once, you sinned three times. God has forbidden you to look into someone's fault and you have done otherwise. God has commanded you to enter peoples' homes through the front door, and you have intruded over the fence. And you have approached me without salutation, and God has commanded you not to enter into other peoples' home without their permission, and without saying greetings (salam) when you enter their premises.

The Caliph Umar asked for the man's forgiveness, was granted it and went on his way. This shows that private life, private information and the affairs of the individual are left to the individual's control and no one, not even the government, has the authority to inquire or investigate an individual's private domain. $^{156}$

The above discussion shows that the concept of privacy in Islam is not so different from Western principles. The importance of dignity, the protection of modesty, and a clear division of private and public matters, which are the underlying basis for the protection of privacy in Islam have all been discussed in the West when defining privacy and providing its protection.

The following part discusses privacy from a Malaysian perspective, particularly that of the Malays, in order to determine relevant protection for privacy in Malaysia.

\footnotetext{
${ }^{156}$ At 141.
} 


\section{Privacy from a Malaysian Perspective}

Malaysia has a multi-cultural and multi-racial population consisting of Malays, Chinese, Indians and numerous indigenous peoples. ${ }^{157}$ Malays and indigenous people comprise $67.4 \%$ of the population, $24.6 \%$ are Chinese, $7.3 \%$ are Indians and other ethnicities comprise $0.7 \% .{ }^{158}$ With such a varied ethnic composition, a great diversity of religions prevails throughout Malaysia. Although Islam is the official religion, ${ }^{159}$ and the most widely professed religion with the proportion of $61.35 \%$, all other religions including Buddhism (19.8\%), Christianity (9.2\%) Hinduism (6.3\%) and tribal religions are practised freely. ${ }^{160}$

There is a strong link between the country's multi-racial and multi-cultural combination and its history. Besides the local Malays and the native groups, immigrants from China, India, and other parts of the world have contributed to the multi-racial composition of the population. The country's cultural diversity can be largely attributed to its long and on-going interaction with the outside world and colonial rule by the Portuguese, Dutch and the British. ${ }^{161}$

\footnotetext{
${ }^{157}$ The Orang Asli are the indigenous peoples or native groups of Peninsular Malaysia. Anthropologists and government officials have traditionally regarded the Orang Asli as consisting of three main groups, comprising several distinct sub-groups: Negrito (Semang), Senoi and Aboriginal-Malay. In Sarawak, the indigenous peoples are collectively called Orang Ulu or Dayak and include the Iban, Bidayuh, Kenyah, Kayan, Kedayan, Mu-rut, Punan, Bisayah, Kelabit, Berawan and Penan. The 39 different indigenous ethnic groups in Sabah are called natives or Anak Negeri.(Source: http://www.iwgia.org/regions/asia/malaysia/877-update-2011-malaysia).

158 (Source: Bureau of East Asian \& Pacific Affairs), as at March 2012. See also (Source: Population Distribution and Basic Demographic Characteristics 2010, Department of Statistic Malaysia, Chart 7: Percentage Distribution of the Population by the Ethnic Group, Malaysia 2010).

http://www.statistics.gov.my/portal/download_Population/files/census2010/Taburan_Pendudu k_dan_Ciri-ciri_Asas_Demografi.pdf

${ }^{159}$ Article 3(1) of the Federal Constitution provides that "Islam is the religion of the Federation; but other religions may be practised in peace and harmony in any part of the Federation".

${ }^{160}$ Above n 158.

${ }^{161}$ Foreign colonisation of Malaysia began when it was conquered by the Portuguese (15111641), followed by the Dutch (1641-1824), then occupation by the British (1824-1942). The country was under Japanese occupation from 1942-1945 before it came under the British rule again in 1945 until its independence in 1957.
} 
This has resulted in its unique blend of religions, socio-cultural activities, customs and traditions, dress and costume, languages and perspectives. The value of privacy is reflected in every aspect of the population's daily transactions.

Islam in Malaysia is thus closely associated with the Malay people. A Malay is defined in the Constitution as "a person who professes the religion of Islam, habitually speaks the Malay language, conforms to Malay custom”. ${ }^{162}$ According to Abdul Hamid, this definition suggests that the first test of a person's race is his religion, and that this provision is unique. ${ }^{163}$

In Malaysian society where moral principles and values are highly upheld and preserved, privacy as a basic human value is not an alien concept. The concept of privacy underpins traditional Malay cultures in terms of individual personality and social interactions. Communities in Malaysia are often close knit, with communal needs, necessities and requirements transcending those of individuals. Extended families, tight communities, and tribal customs often mean that the communal understanding of individual privacy is underdeveloped. However, urbanisation and progress, and the attendant migration to bigger cities have, to a certain extent, broken the traditional patterns of communities.

For example, in traditional Malay society, privacy needs are related to beliefs, values and norms which are largely supported by Islamic laws. ${ }^{164}$ In terms of family privacy, women are protected from being seen by visitors in the front area of the house. It is the customary practice, as well as Islamic teaching, that

\footnotetext{
${ }^{162}$ Article 160 of the Federal Constitution.

${ }^{163}$ Abdul Hamid Mohamed "Harmonization of Common Law and Shariah in Malaysia: A Practical Approach" (Abd Razzaq Al-Sanhuri Lecture, Islamic Legal studies Program, Harvard Law School, 6 November 2008).

${ }^{164}$ Zainal Kling "The Malay family: Beliefs and realities" (1995) 26 (1) Journal of Comparative Family Studies, 43 at 60. The writer's view was that the Islamic laws, in particular the family laws are to a large extent coterminous with Malay custom.
} 
women and men are separated in all formal social interaction. This is a reflection of the social norms restricting male-female relationships between family and non-family members, relatives, guests and visitors. ${ }^{165}$

This traditional concept has influenced the traditional Malay house and settlement. ${ }^{166}$ Building elements in all Muslim houses play an important role in providing privacy in traditional Malay houses. For example, several elements such as house planning, layout and the relationship between spaces, the position of women, and the segregation of men and women are influenced by the concept of privacy. ${ }^{167}$ Spaces are arranged to avoid direct views into the house and to provide privacy for the female household performing everyday activities, even in the presence of male visitors. ${ }^{168}$

Malay society regards behavioural norms as important privacy regulating mechanisms. ${ }^{169}$ Traditional values of budi (etiquette) and bahasa (language) regulate behaviour in the close-knit Malay society. The term budi bahasa sums up the kind of proper behaviour an individual should display both in the privacy of family life and in public, such as not prying into the private matters of others, giving salutations, and asking permission before entering other people's houses, not looking into other people's houses, as well as rules on clothing and interaction. The observation of accepted behavioural patterns indirectly provides privacy for the community at large. This is much in line with morality as enjoined by Islamic teachings. ${ }^{170}$

\footnotetext{
${ }^{165}$ Ahmad Harizal H, Zaiton AR, Sharifah Norazizan SAR and Nurizan Y "Visual privacy and family intimacy, A case study of Malay inhabitants living in two storey low-cost terrace housing" (2006) 33 Environment and Planning B: Planning and Design, 301.

${ }^{166}$ At 301 .

${ }^{167}$ See T Burckhardt Art of Islam: Language and Meaning (Westerham Press, Edenbridge, Kent, 1976); G Mitchell Architecture of the Islamic World (Thames and Hudson, London, 1987) and Mohamad Tajuddin MR Essays on Architecture Volume 1 (Universiti Teknologi Malaysia, Johor, 1997); as discussed in Ahmad Harizal et al, above n 165.

${ }^{168}$ Harizal et al, above $\mathrm{n} 165$ at 305.

${ }^{169}$ Zainal, above n 164, at 60.

170 At 60.
} 
In term of costume and dress, Malay women wear the baju kurung which is a knee-length blouse worn over a long skirt. The head is covered with a scarf or shawl. Such an outfit is worn to cover specific parts of the body ('aurah) and to protect women's honour and dignity. Malay men can wear anything but should cover themselves from navel to the knee. ${ }^{171}$

Malaysian culture has played a significant role in shaping attitudes and perspectives of privacy. Traditional Malay values relating to privacy reveal its connection to Islamic ideas of privacy mentioned in the Holy Quran more than 1400 years ago. ${ }^{172}$

\section{Conclusion}

A vast amount of existing literature reveals that the notion of privacy, its conceptualisation and theory is problematic. Various definitions have been proposed for privacy which may encompass both physical and informational aspects. Some scholars perceive it as a form of control, while others believe it to be a state or condition of life.

Privacy is a socially generated need which involves one's relationship with society. If a person is living alone, asserting that one has privacy is meaningless. A common example is a person stranded on a deserted island; that person has absolute privacy, but this does not make much sense as the person is actually in a state of isolation. Thus, to define privacy as a form of control simply because a person has control over himself in the given example

\footnotetext{
${ }^{171}$ Narrated by 'Ali (R.A): The Messenger of Allah (pbuh) said: "Do not show your thigh, and do not look at the thigh of anyone, living or dead."(Abu Dawood (3140) and Ibn Maajah: 1460). The majority of fuqaha' are of the view that these ahaadeeth should be followed and they stated that a man's 'aurah is from the navel to the knee. See Ibn Qudamah and Muwaffaq al-Din al Maqdisi al-Mughni (Riyadh, Al-Maktabah al Haditsah, 1984) at 2/284. Most of the scholars say it is an authentic hadith and a man should cover navel to knee.

${ }^{172}$ The revelation of the Holy Quran began in the year $610 \mathrm{CE}$.
} 
is unnecessary. However, privacy is not lost if a person lives alone because nobody is interested in knowing his affairs.

In the context of this thesis, Gavison's definition that privacy is a "condition" is the most satisfactory. By employing her definition, it does not matter whether a person lives alone or in a society: as long as they are completely inaccessible, then they are enjoying their privacy. Privacy is required for the protection of an individual's physical body and space, as well as personal information. In both situations, privacy in the sense of limited access to the self by others is the most appropriate definition. The word "self" here is not confined to an individual's physical being only, but includes information; for the reason that knowing someone's physical traits conveys specific information.

Combining Gavison's approach of "limitation of other's access to individual" and Moreham's definition of "freedom from unwanted access", this thesis views a breach of privacy as unwanted access to the physical body and space as well as to information which warrants legal protection for its invasion. An individual, therefore, has a right to determine the extent to which he wishes to share matters with others or to keep them to himself or herself. In other words, if people wish to keep their affairs to themselves, they have an absolute right to do so and to decide the extent to which the same will be shared with others. Thus, both Islamic and Western societies recognise that individuals and groups are entitled to put up barriers around aspects of themselves and to exclude others. At a high level, then, the cultural attitudes of the two cultures are arguably the same. Both cultures accept that people's reasonable expectations of privacy need to be respected, and that what amounts to a reasonable expectation of privacy in any given situation will differ.

The discussion of Islamic views of privacy, the concept of private and public spheres, and Malaysian perspectives of privacy strengthen the definition of 
privacy used in this thesis. Discussion of the Western concept and notion of privacy shows that the idea of privacy generally is consistent with Islamic principles and traditional Malay societies. The discussion of both concepts is aimed at providing a social background for Malaysia privacy law. It is, therefore, appropriate to look to Western theorists and principles for a framework that would work in Malaysia. As in New Zealand and England, it is envisaged that the precise scope of the reasonable expectation of privacy in Malaysia will be determined on a case by case basis.

Having established the meaning of privacy and the scope of its protection, the next chapter discusses the state of privacy protection in Malaysia and its significant development in the Malaysian legal framework. 


\section{PART II: CURRENT PROTECTIONS IN MALAYSIA \\ CHAPTER THREE \\ PROTECTION OF PRIVACY INTERESTS IN MALAYSIA}

\section{Overview}

The discussion in Part II is divided into two chapters. Chapter Three discusses the current framework for the protection of privacy interests in order to emphasise the inadequacies of the protections in Malaysia. Chapter Four examines all relevant statutory protection of privacy currently in force in Malaysia. It analyses the Personal Data Protection Act 2010 (PDPA) and compares it with the laws on personal data of the two model jurisdictions ie UK and New Zealand.

As discussed in Part I, there is no general right to privacy in Malaysia, and ultimately there is no specific protection afforded by its breach. Privacy infringements are not uncommon in Malaysia. The problems are serious and require immediate legal attention. The ability of existing laws to address the matter is disputable thus further development of the law is necessary to provide comprehensive legal protection against breaches of privacy. Privacy, as defined in Chapter Two which is consistent with Western and Islamic principles informs the shape of privacy protection in a Malaysian context. Furthermore, the importance of privacy is related to the protection of human rights and human dignity which are unanimously acknowledged by all theorists.

When the Constitution was drafted in 1956, the right to privacy was not given equal status with certain other rights. However, with the development of information and communications technology and its influence on modern life, this inequality must be remedied by the development of law. The existing 
framework needs to change in order to reflect the importance of individual privacy and to provide necessary protection to safeguard the interest in privacy.

This chapter deals with the current state of the law in Malaysia as it relates to privacy and is divided into seven parts. Part I details the subject matters of discussion in this chapter. Part II discusses the historical background of the law in force in Malaysia as it originates from English common law. Part III examines constitutional protection of privacy derived from art 5 of the Constitution. Relevant common law principles for the protection of privacy interests are discussed in Part IV to assess their adequacy in addressing any breach of privacy. The judicial development of the right to privacy in tort and other cases is discussed in Part V. Part VI concludes the discussion of Malaysian privacy law.

\section{Applicability of English Common Law in Malaysia}

Discussion of privacy in Malaysian private law must begin with a consideration of the application of English law in Malaysia. The Malaysian legal system, especially the common law, is historically connected to the English legal system. Although the Malaysian legal system also reflects Portuguese, Dutch, Japanese and British influence, it was the British occupation which had the most significant influence on local rules and regulations.

The introduction and reception of English law began in 1807 through the First Royal Charter of Justice with the establishment of a Court of Judicature of Penang. As a result, English law became applicable to local inhabitants 
including British and non-British subjects. ${ }^{1}$ In order to implement their law, British judges declared no law or legal system existed at that time in Malaya, and thus resorted to English common law, rules of equity and English statutes although there were no clear provisions in the Charter that required the importation of English law. ${ }^{2}$

The formal reception of English common law and the rules of equity into the local system was made through the Civil Law Ordinance 1956. In 1956, it was amended and renamed the Civil Law Act 1956 (the CLA) to facilitate its application to all states in the Federation of Malaya. By virtue of the CLA, judges were obliged to apply English common law and the rules of equity to local cases.

The CLA provides three relevant sections for the application of English law. ${ }^{3}$ English common law and rules of equity formed part of unwritten sources of Malaysian law. ${ }^{4}$ Section 3 of the CLA states that courts in the Malaysian Peninsula should apply English common law and rules of equity as administered in England on 7 April 1956. The same provision provides that the courts in both states should apply English common law, rules of equity

\footnotetext{
${ }^{1}$ In 1826, the Second Royal Charter of Justice extended the application of English law to the Straits Settlement comprised of Penang, Malacca and Singapore.

${ }^{2}$ Shamrahayu A Aziz "The Malaysian Legal System: The Roots, The Influence and the Future" (2009) 3 MLJ xcii. The author said that when discussing the history of the application of English law in Malaya, it is important to note that the position of Islam and Malay custom remained inviolable and were left unaffected by the British. See also Ong Cheng Neo v Yeap Cheah Neo (1875) LR 6 PC 381, at 393.

${ }^{3}$ Sections 3, 5 and 6 of the CLA 1956.

${ }^{4}$ The sources of Malaysian law can be classified into written and unwritten laws. Written law includes the Federal and State Constitutions, legislation enacted by Parliament and subsidiary legislation made by persons or bodies under powers conferred on them by Acts of Parliament or State Assemblies. On the other hand, unwritten law comprises principles of English law applicable to local circumstances, judicial decisions of the superior courts (High Courts, Court of Appeal and Federal Court), and customs of the local inhabitants which have been accepted as law by the courts. See Lee Mei Pheng General Principles of Malaysian Laws (5 $5^{\text {th }}$ ed, Oxford Fajar Sdn Bhd, Malaysia, 2005).
} 
together with statutes of general application as administered in England on 1 December 1951 in Sabah, and 12 December 1949 in Sarawak respectively. ${ }^{5}$

Although the relevant provisions allow the application of English common law and rules of equity in deciding local cases, the authorisation does not suggest that the Malaysian court must import English law comprehensively and in its entirety. English common law and rules of equity may be applied subject to two conditions: first, only in so far as the circumstances permit and second, in the absence of local legislation. ${ }^{6}$

Circumstances in the first condition refer to respective laws and customs of the local inhabitants. In In the Goods of Abdullah, Sir Benjamin Malkin held that the religions and customs of the local inhabitants were recognised as exceptions to the general application of English law, particularly in the ecclesiastical jurisdiction, by the general principles of English law, not by the Charter. ${ }^{7}$ This important qualification of English law in local law was confirmed in Choa Choon Neoh $v$ Spottiswoode ${ }^{8}$ in which the court held that any application of the law to various subjects must conform to the condition

\footnotetext{
${ }^{5}$ Section 3 (1) provides for a general application of English law. It provides "Save so far as other provision has been made or may hereafter be made by any written law in force in Malaysia, the Court shall: (a) in West Malaysia or any part thereof, apply the common law of England and the rules of equity as administered in England on the 7th day of April, 1956; (b) in Sabah, apply the common law of England and the rules of equity, together with statutes of general application, as administered or in force in England on the 1st day of December, 1951; (c) in Sarawak, apply the common law of England and the rules of equity, together with statutes of general application, as administered or in force in England on the $12^{\text {th }}$ day of December, 1949, subject however to sub-section 3 (ii): Provided always that the said common law, rules of equity and statutes of general application shall be applied so far only as the circumstances of the States of Malaysia and their respective inhabitants permit and subject to such qualifications as local circumstances render necessary".

${ }^{6}$ Wan Arfah Hamzah and Ramy Bulan An Introduction to the Malaysian Legal System (Oxford Fajar Sdn Bhd, Malaysia, 2003) at 112-114 [An Introduction to the Malaysian Legal System].

${ }^{7}$ In the Goods of Abdullah (1835) 2 Ky Ecc 8 at 11. See also Wan Arfah and Ramy, above $\mathrm{n}$ 6 , at 105 .

${ }^{8}(1869) 1 \mathrm{Ky} 216$.
} 
and wants of inhabitants as far as is necessary to prevent unjust consequences and oppression. ${ }^{9}$

With regards to the second condition, in terms of the hierarchy of the law, an Act of Parliament takes precedence over English common law. This means that where the common law on a particular subject is superseded by legislation, the court's duty is to interpret the statute without recourse to the common law existing before the statute was enacted. English common law is only meant to fill the lacunae, when local legislation is not present. ${ }^{10}$ The fact that there is local legislation does not necessarily mean that common law in the area is irrelevant. There will be occasions where a statute does not cover a point, and thus, reference to case law or English common law may be necessary.

In Yong Joo Lin v Fung Poi Fong ${ }^{11}$ Terrell Ag CJ held that principles of English law were for many years accepted in the Federated Malay States where no other provision was made by statute, and that the qualification contained in s 3(1) was in fact the statutory recognition of the judicial practice of resorting to English law to fill the lacunae in the local law. ${ }^{12}$

Before applying English common law, the court must first determine whether written law is already in force in Malaysia. If there is none, the court should determine the relevant common law, and the rules of equity as administered in England since 7 April 1956. The "cut-off date" signifies that the court should determine English common law at the date of reception, and how it has been modified and developed locally since that date. Having done that, the court should consider whether its application is permitted as such by local circumstances. If it is "permissible", then the court should apply it.

\footnotetext{
${ }^{9}$ At 211.

${ }^{10}$ Wan Arfah and Ramy, above n 6, at 105.

${ }^{11}$ [1941] MLJ Rep 54.

${ }^{12}$ At 55 .
} 
Once permissible, the English common law principle is binding. However, if the court finds that such a principle is not "permissible", the court is free to reject it or adopt any part which is "permissible", with or without qualification. Where the court rejects it wholly or in part, the court is free to formulate Malaysia's own common law. In so doing, the court is at liberty to look at any source of law, local or otherwise, principles of common law in other countries, Islamic law of common application or common customs of the people of Malaysia.

In practice, the courts may follow developments in English common law after such dates, but any English law referred to after the date specified, and current decisions of the English courts will be treated as persuasive authority only and may simply be useful comparative analogies. ${ }^{13}$ Although English common law after 7 April 1956 is not binding on Malaysian courts, reference to it may still be made in deciding local cases.

To conclude, judges are free to develop Malaysian law in two situations. First, they may refer to English common law before the "cut-off date" which was binding on Malaysian courts, provided no local legislation already applies. Second, judges may refer to English law after the "cut-off date" as a persuasive source of law, laws of the Commonwealth jurisdictions or Islamic law in making their decisions, as long as the laws suit local conditions and circumstances. Although the two sources of the law before and after the "cutoff date" are treated differently, they remain the most useful reference for Malaysian courts. It is not surprising, therefore, that judges continue to refer

\footnotetext{
${ }^{13}$ For general discussion of the Malaysian legal system and the reception of English common law principles in Malaysia, refer Wu MA The Malaysian Legal System $\left(3^{\text {rd }}\right.$ ed, Pearson Malaysia Sdn Bhd, Kuala Lumpur, 2007). Refer also Ahmad Ibrahim and Ahilemah Joned The Malaysian Legal System (Dewan Bahasa dan Pustaka, Malaysia, 1987). See also Jamil bin Harun v Yang Kamsiah [1984] 1 MLJ 217, where the court held that "it is for the courts in Malaysia to decide, subject always to the statute law of the Federation, whether to follow English law. Modern English authorities may be persuasive, but are not binding. In determining whether to accept their guidance the courts will have regard to the circumstances of the states of Malaysia and will be careful to apply them only to the extent that the written law permits and no further than in their view it is just to do so".
} 
to English law, in particular, the law of privacy as long it is acceptable to local people and consistent with local circumstances.

The next part will discuss the position of the right to privacy in the Constitution. The absence of an express recognition of the right to privacy in the Constitution raises the question of whether there is any possibility of developing this right within the explicit rights guaranteed by the Constitution.

\section{Constitutional Protection of Privacy}

As discussed in Chapter Two, privacy is a fundamental human right related to the idea of liberty. The Constitution, as the guardian of fundamental rights and freedoms, expressly provides protection for these rights. However, there is no express right to privacy guaranteed by the Constitution. How far, therefore, do the explicit rights protect privacy as defined by this thesis? In this Part, the relationship between common law and the Constitution is addressed in order to emphasise the status of privacy as a tort. Having discussed this relationship, the possibility of developing a constitutional protection of privacy from the explicit protection of the right to life and personal liberty is analysed. This analysis leads to a consideration of the development of a constitutional right to privacy in India which has significantly influenced such development in Malaysia.

\section{A The Relationship between the Common Law and the Constitution}

The subject of privacy and its protection is a branch of tort law which governs the interactions between individuals. So far, despite some indications that courts will be developing it in the future, a privacy tort is not an actionable 
cause of action in Malaysia. ${ }^{14}$ Since a private action for damages for breach of privacy is therefore hard to maintain, and common law must develop consistently with the Constitution, the protection of privacy may be derived from constitutional law. As a part of human rights, the right to privacy may be protected by the Constitution which provides for fundamental rights of every citizen.

The Constitution is the supreme law of Malaysia which provides for the protection of individual against arbitrary powers of the state. Article 4 (1) states that "This Constitution is the supreme law of the Federation and any law passed after Merdeka (Independence) Day which is inconsistent with this Constitution shall, to the extent of the inconsistency, be void".

The above provision signifies that the Constitution prevails over common law where inconsistency exists.

Thus Malaysian common law will continue to develop by taking into account the subsequent development of English common law without the need to amend the Civil Law Act 1956. The proviso to s 3 of the CLA requires that regard be given to local circumstances when applying English law and enables Malaysia to create its own common law. The Act never intended the wholesale application of English law. ${ }^{15}$ In this regard, art 162 of the Constitution provides for the continuation of existing laws after Merdeka Day. ${ }^{16}$ As long as

\footnotetext{
${ }^{14}$ The judicial development of the right to privacy in Maslinda Ishak $v$ Mohd Tahir Osman \& Ors [2009] 6 MLJ 826, [2009] 6 CLJ 653 (CA) and other privacy cases is discussed below in Part V.

${ }^{15}$ See Jamil bin Harun v Yang Kamsiah \& Anor [1984] 1 MLJ 217 (PC); Chung Khiaw Bank Ltd v Hotel Rasa Sayang Sdn Bhd \& Anor [1990] 1 MLJ 356, at 361; Sri Inai (Pulau Pinang) Sdn Bhd v Yang Yit Swee [2003] 1 MLJ 273, at 285; Danaharta Urus Sdn Bhd v Kekatong Sdn Bhd (Attorney General Malaysia) [2004] 2 MLJ 257 as discussed in Farid Sufian Shuaib "Towards Malaysian Common Law: Convergence Between Indigenous Norm and Common Law Methods" (2009) Jurnal Undang-undang 158, at 164.

${ }^{16}$ Merdeka Day means Independence Day for Malaysia which was on $31^{\mathrm{t}}$ August 1957. Article 162(1) provides that "Subject to the following provisions of this art and art 163, the existing laws shall until repealed by the authority having power to do so under this
} 
the supremacy of the Constitution is adhered to, Malaysian common law has absolute freedom to develop.

\section{B Fundamental Liberties under the Constitution}

The Constitution came into force in 1957 and provides for the establishment of three main branches of government: the legislative branch called the Parliament, which consists of the House of Representatives (in Malay, Dewan Rakyat), and the Senate (Dewan Negara), the executive branch led by the Prime Minister and his Cabinet Ministers, and the judicial branch headed by the Federal Court. The Constitution also defines the rights and responsibilities of the federal government, the member states of the federation and the citizens and their relations to one another.

Human rights in Malaysia are governed by the Constitution. ${ }^{17}$ A commission called SUHAKAM was established under the Human Rights Commission Act 1999 (HRCA) to advise and assist the government in matters pertaining to human rights. The HRCA has imported into Malaysian constitutional law the international human rights enshrined in the UDHR 1948. Section 4(4) of the HRCA provides that whatever rights and liberties not mentioned in the HRCA but referred to in the UDHR 1948 must be considered provided that there is no conflict with the Constitution. ${ }^{18}$

Constitution, continue in force on and after Merdeka Day, with such modifications as may be made therein under this Article and subject to any amendments made by federal or State law." ${ }^{17}$ Section 2 of Human Rights Commission of Malaysia Act 1999 provides that "human rights" refer to fundamental liberties as guaranteed in Part II of the Constitution. Aziz stated that the term "fundamental liberties" may refer to the rights which the constitution considers fundamental and basic, or that it refers to the rights that are so fundamental so they cannot be taken away except through special procedures laid down by the Constitution. See Abdul Aziz Bari Malaysian Constitution: A Critical Introduction (The Other Press, Kuala Lumpur, 2003) at 143.

${ }^{18}$ Section 4(4) states "For the purpose of this Act, regard shall be had to the Universal Declaration of Human Rights 1948 to the extent that it is not inconsistent with the Federal Constitution. 
In 1957 when the Constitution was drafted, the range of human rights such as freedom of life and liberty, freedom of expression, freedom of religion, freedom of movement and association were among the rights that were directly recognised in the Constitution. ${ }^{19}$ Those rights are contained in arts 513 of the Constitution. The right to privacy, however, is not mentioned. The effect of such an absence is that other rights, such as that of freedom of expression, override the right to privacy when rights compete with each other. It is submitted that among the rights, the right to life and personal liberty in art 5 has an implication for the protection of aspects of privacy interest.

\section{$1 \quad$ Article 5 right to life and personal liberty}

The right to life and personal liberty is provided by art 5 of the Constitution which states "No person shall be deprived of his life or personal liberty save in accordance with law".

There are two important rights contained in this provision: The right to life and the right to personal liberty. ${ }^{20}$ The Constitution embodies British and Indian constitutional concepts and traditional Malay elements. Though largely based on the Indian Constitution, the Malaysian Constitution developed from an earlier constitution drafted by a commission of foreign experts. ${ }^{21}$ Being a

\footnotetext{
${ }^{19}$ Relevant provisions are art 5 right to life and personal liberty, art 6 on slavery and forced labour prohibited, art 7 on protection against retrospective criminal laws and repeated trials, art 8 on equality, art 9 on prohibition of banishment and freedom of movement, art 10 on freedom of speech, assembly and association, art 11 on freedom of religion, art 12 on rights in respect of education and art 13 on rights to property.

${ }^{20}$ For general discussion of art 5, see A Sheridan and HE Groves The Constitution of Malaysia ( $4^{\text {th }}$ ed, Malayan Law Journal Pte Ltd, Singapore, 1987) at 41-51; HE Groves "Kebebasan Asasi Dalam Perlembagaan Persekutuan Malaysia" in M Suffian, HP Lee and FATrindade Perlembagaan Malaysia Perkembangannya: 1957-1977 (Penerbit Fajar Bakti Sdn Bhd, Malaysia, 1983) at 36-38; S Jayakumar Constitutional Law Cases From Malaysia and Singapore ( $2^{\text {nd }}$ ed, Malayan Law Journal Pte Ltd, Singapore, 1976) at 44-94.

${ }^{21}$ The Reid Commission, consisting of constitutional experts from fellow Commonwealth countries and headed by Lord Reid was appointed to make recommendations for a suitable constitution. The report of the Commission was completed on 11 February 1957. The Federal Constitution was proclaimed on the basis of the recommendations.
} 
written constitution, it serves as a basic law to which all legislative and executive actions are subject.

It was observed by the Chief Justice Hughes of the Supreme Court that "we are under a constitution but the constitution is what the Judges say it is". 22 Therefore, the judges, when interpreting the Constitution, play a major role in construing the words that ensure the right balance between parties and achieving a just decision.

The right to life and personal liberty encompasses privacy interests in the sense that everybody has the right to livelihood ${ }^{23}$ and the right be let alone. On the other hand, personal liberty guaranteed by the Constitution implies wider human rights values and includes privacy as interpreted by case law.

Lord Diplock in Minister of Home Affairs v Fisher ${ }^{24}$ maintained that a written constitution based on the Westminster model was a "document sui generis which called for principles of interpretation and provisions to be generously interpreted to give full recognition and effects to the fundamental rights and freedoms referred to".

This suggests that the absence of an express recognition of certain rights in the Constitution does not mean there is no room for such recognition by the courts in order to give life and meaning to the cold letter of the law. According to the "strict constructionists", the Constitution should be interpreted in accordance

\footnotetext{
${ }^{22}$ See MP Jain Indian Constitutional Law ( $4^{\text {th }}$ ed, LexisNexis Butterworths, 2001) at 834. ${ }^{23}$ Hong Leong Equipment Sdn Bhd v Liew Fook Chuan [1996] 1 MLJ 481, at 510. The court held that the right to livelihood is one of the fundamental liberties guaranteed under Part II of the Federal Constitution.

${ }^{24}[1979] 3$ All ER 21 at 25.
} 
with the original intention of its framers. ${ }^{25}$ Provisions are interpreted based on the "plain language" that appeared in the original text.

On this approach, the right to privacy is not a fundamental right enshrined in the Constitution. When interpreting the Constitution, judges cannot afford to be too liberal. They are justified in giving effect to what is implicit in the basic law and in crystallising what is inherent. In so doing, words or clauses of the Constitution may be construed in various ways. A word or the plain language of the provision, its structure and ordinary sense should be given its due effect. ${ }^{26}$ Thus, the interpretation is direct and simple.

Another way of interpreting the Constitution is the liberal approach. The "legal realists" argue that the interpretive task is unavoidably creative because legal words do not necessarily have a self-evident meaning. The courts and judges determine meaning by a dynamic interpretation of legal principles that are complementary to changing social needs and conditions. A constitutional provision, therefore, should be read in the overall context of the rest of the Constitution. By applying this approach, any superficial or literal approach to interpretation should be rejected. ${ }^{27}$

Shad observed that interpretation should be based on rights and principles. ${ }^{28}$ The provisions of the Constitution should be viewed in the context of the entire system of laws and with regard to the moral principles, doctrines, standards and framework assumptions implicit in basic law. ${ }^{29}$ The fundamental purpose of interpretation is to safeguard not only textual rights but also rights implicit in the Constitution.

\footnotetext{
${ }^{25}$ Shaad Saleem Faruqi "Constitutional Interpretation in a Globalised World" (2005) $<w w w . m a l a y s i a n b a r . o r g . m y>$.

${ }^{26}$ Shaad, at <www.malaysianbar.org.my>.

${ }^{27}$ Shad, above n 25.

${ }^{28}$ Shad, above $\mathrm{n} 25$.

${ }^{29}$ Shad, above n 25 .
} 
Because the nature of the constitution differs fundamentally from ordinary legislation, the construction applicable to ordinary statutes should not be applied rigidly to constitutional instruments. In Dato' Menteri Othman Baginda v Dato' Ombi Syed Alwi bin Syed Idrus ${ }^{30}$ the court said:

A constitution, being a living piece of legislation, its provisions must be construed broadly and not in a pedantic way, that is "with less rigidity and more generosity than other Acts".

A similar opinion was expressed earlier in Minister of Home Affairs $v$ Fisher $^{31}$ : That the provisions of the Constitution were to be generously interpreted to give full recognition and effect to the fundamental rights and freedoms referred to. Due to the rigidity of the Constitution, a literal approach is not a suitable means of interpreting fundamental rights.

In a literal interpretation of fundamental rights, "life" means mere animal existence, and personal liberty simply freedom from arrest. In Tan Tek Seng v Suruhanjaya Perkhidmatan Pendidik \& Anor ${ }^{32}$ the court stated that judges adopt a liberal approach when interpreting the supreme law in order to implement the true intention of the framers of the Constitution. Such an objective is achieved if "life" and "personal liberty" are given a broad and liberal meaning.

\section{Judicial interpretation of article 5 of the Constitution}

Article 5 guarantees every person a right to life and liberty. A person's life or personal liberty cannot be taken away unless it is in accordance with law. The

\footnotetext{
${ }^{30}$ [1981] 1 MLJ 29.

${ }^{31}$ [1979] 3 All ER 21.

${ }^{32}$ [1996] 1 MLJ 481 (Tan Tek Seng).
} 
courts have said that the right to life includes a right to livelihood and quality of life, ${ }^{33}$ while the right to personal liberty includes the right to privacy. ${ }^{34}$

The court, through judicial interpretation of the constitutional provisions, has the power to expand or narrow the horizons of freedom. In Tan Tek Seng ${ }^{35}$, the appellant was the headmaster of a school. He was, in that capacity, entrusted with a sum of RM3,179.00 belonging to the Johore Education Department ("the Department"). This sum constituted the unpaid salary of the school's gardener who had not turned up for work for several months. Under the relevant financial regulations that governed the duties of the appellant, he was obliged to return this sum of money to the Department but he failed to do so. When he was asked for the money, the appellant told them that it had been sent to them which was not true. He had not returned the money. He had not used the money, merely kept it. Eventually he did send the money to the Department and was charged with an offence under s 409 of the Penal Code because he retained the money. The Session Court found that he was guilty. He was sentenced to six months imprisonment.

The appellant appealed to the High Court, and the Judicial Commissioner, affirmed the finding of guilt but set aside the conviction and sentence, and instead made an order that the appellant be bound over to be of good behaviour for three years in RM5000 without sureties under s 173A(ii)(b) Criminal Procedure Code (CPC). Pursuant to that, the Johore Education Department wrote to the Education Service Commission, the relevant disciplinary authority, recommending that disciplinary action be taken against the appellant. It recommended that the appellant be reduced in rank and salary pursuant to General Order 36 of the Public Officers (Conduct and Discipline) (Chapter “D”) General Orders 1980.

\footnotetext{
${ }^{33}$ Lee Kwan Woh v PP [2009] 5 CLJ 631 per Gopal Sri Ram FCJ at 639 (Lee).

${ }^{34}$ Sivarasa Rasiah v Badan Peguam Malaysia \& Anor [2010] 3 CLJ 507 per Gopal Sri Ram FCJ at 591 (Sivarasa).

${ }^{35}$ Tan Tek Seng, above n 32.
} 
The appellant, being dissatisfied with his dismissal, instituted proceedings to challenge it. He sought two declarations: firstly, that his dismissal was null and void and of no effect and secondly, that he was still a member of the Public Service. Among the issues was whether the Government was entitled to summarily dismiss him in reliance on the finding of guilt, and if not, whether it was obliged to take into account the particular circumstances of the case and impose a lesser punishment. The court stated that the expression "life" appearing in art 5(1) of the Federal Constitution does not refer to mere existence. It incorporates all those facets that are an integral part of life itself, and those attributes which go to form the quality of life. For the purpose of the case, the word "life" encompassed the right to continue in public service subject to removal for good cause by resort to fair procedure.

The case is significant because the judge's interpretation expands the constitutional right of the word "life".

In Sugumar Balakrishnan v Pengarah Imegresen Negeri Sabah \& Anor, ${ }^{36}$ the Court of Appeal adopted Indian jurisprudence (art 21 of the Indian Constitution) on the wide meaning of life and personal liberty:

In our judgment, the words "personal liberty" in Art 5(1) should be similarly interpreted. Any other approach to construction will necessarily produce an incongruous and absurd result. For "life" and "personal liberty" are both equally dynamic concepts and should be treated in like fashion.

This interpretative dynamism was introduced by Bhagwati $\mathrm{J}$ in Maneka Ghandi $v$ Union of India. ${ }^{37}$ The judge held that the life and liberty provision and the equality provision are interrelated; that they support each other and should not be read as having a separate existence. This proposition that the

\footnotetext{
${ }^{36}[1998] 3$ MLJ 289 (CA).

${ }^{37}$ [1978] AIR 597.
} 
words "personal liberty" should be given a generous interpretation was rejected by the Federal Court in Pihak Berkuasa Negeri Sabah v Sugumar Balakrishnan ${ }^{38}$ which argued that "personal liberty" should have a contextual meaning and that art 5(1) merely provided for freedom from being unlawfully detained. Thus, the court disagreed with Bhagwati J's view that the words be generously and widely interpreted.

The court in Sivarasa Rasiah v Badan Peguam Malaysia and Anor ${ }^{39}$ expressed the view that the methodology of interpretation must be taken into account when interpreting fundamental rights. The Federal Court in three cases $^{40}$ has held that in dealing with the provisions on fundamental liberties, they must be generously interpreted and a prismatic approach to interpretation must be adopted. "Life" and "personal liberty" must be interpreted as widely as possible ${ }^{41}$ in order to expose or reveal the rights contained in the concepts already expressly guaranteed. In Lee Kwan Woh $v$ PP the court said: ${ }^{42}$

On no account should a literal construction be placed on the Constitution's language, particularly upon those provisions that guarantee to individuals the protection of fundamental rights. In our view, it is the duty of a court to adopt a prismatic approach when interpreting the fundamental rights guaranteed under Part II of the Constitution. When light passes through a prism it reveals its constituent colours. In the same way, the prismatic interpretive approach will reveal to the court the rights submerged in the concepts employed by the several provisions under Part II. Indeed the prismatic interpretation of the Constitution gives life to abstract concepts such as "life" and "personal liberty" in Article 5(1).

\footnotetext{
${ }^{38}$ [2002] 3 MLJ 72 (FC).

${ }^{39}$ Sivarasa, above n 34.

${ }^{40}$ Badan Peguam Malaysia v Kerajaan Malaysia [2008] 1 CLJ 521 (Badan Peguam Malaysia); Lee, above $\mathrm{n} 33$ and Shamim Reza v Public Prosecutor [2009] 6 CLJ 93.

${ }^{41}$ Badan Peguam Malaysia, above n 40.

${ }^{42}$ Lee, above, n 33, at 639.
} 
In Sivarasa, an appellant was an advocate and solicitor. At the same time he was also an office bearer of a political party and a Member of Parliament. The appellant wished to be elected to the Bar Council, the governing body of the Malaysian Bar. However, s 46A(1) of the Legal Profession Act 1976 (LPA) prohibited him from doing so. As a result, he challenged the constitutionality of $s 46 \mathrm{~A}(1)$ on the grounds that (i) the section violated his rights of equality and equal protection guaranteed by art $8(1)$ of the Constitution; (ii) that it violated his right of association guaranteed by art 10(1)(c); and (iii) that it violated his right to personal liberty guaranteed by art 5(1). It was further contended that if in any event any one of these rights was found to be violated, s 46A(1) must be declared void as being inconsistent with the supreme law.

The court concluded that $\mathrm{s} 46 \mathrm{~A}$ of the LPA did not violate art 5(1) or art 8(1) and art 10(1)(c) and that it was a valid law. Another important finding by Gopal Sri Ram FCJ was that "personal liberty" in art 5(1) includes within its compass other rights such as the right to privacy. Thus, the right to privacy may now be recognised under the Malaysian Constitution by virtue of art 5(1) parallel to other rights guaranteed by the Constitution as fundamental rights protected by the Constitution. However, the part of the judgment that expressed privacy as being included under art 5 was obiter and did not form the reason for the decision.

A clear statement of the range of art 5 was given obiter in Sivarasa. The court there held that the right to privacy was recognised under the Constitution through the interpretation of the phrase "personal liberty". This decision is notable for two reasons. First, the recognition of the right through a written constitutional provision changed the landscape for the protection of privacy from the domain of common law to a constitutional matter. Second, it questions whether a right, which is implicitly recognised, enjoys the same status as explicit rights in the Constitution. 
Based on the interpretation of "personal liberty" in previous cases, the Federal Court ${ }^{43}$ in Sivarasa held that the right to privacy is encompassed within the right to life and personal liberty under art 5(1) of the Constitution. The inclusion of the right to privacy under art 5(1) was a result of court's observation of Indian cases regarding constitutionally guaranteed rights provisions. ${ }^{44}$ Having regard to the Indian authorities' interpretation of "personal liberty" enabled the court to conclude that it is clear that although the right to privacy is not expressly provided under the Constitution, it may be protected implicitly.

Given the court's reliance on Indian precedents in Sivarasa, it is important to discuss the cases in some detail.

\section{Indian Precedent}

In India, the court assisted the growth of privacy protection by developing this right through rights enumerated in the Indian Constitution. It concluded that a right enumerated in the Constitution would be meaningless unless certain other implied rights, such as of the freedom of the press were provided for. Although freedom of the press is nowhere expressly provided for in the Constitution, it continues to have a very definite presence by virtue of the fact that it constitutes an indispensable part of art 19(1)(a) which guarantees the right to freedom of speech and expression. ${ }^{45}$ The court further argued that a

\footnotetext{
${ }^{43}$ The Federal Court of Malaysia is the highest judicial authority and the final court of appeal in Malaysia.

${ }^{44}$ The court referred to Kharak Singh $v$ State of Uttar Pradesh [1963] AIR 1295 (SC), when discussing art 21 of the Indian Constitution, Ayyangar J said that "the expression "personal liberty" is used in the article as a compendious term to include within itself all the varieties of rights which go to make up the "personal liberties" of man other than those dealt with in the several clauses of art 19(1). In other words, while art 19(1) deals with particular species or attributes of that freedom, "personal liberty" in art 21 takes in and comprises the residue". The court also referred to Govind v State of Madhya Pradesh [1975] AIR 1378 (SC) when concluding that the right to privacy is protected under the broad umbrella of personal liberty.

${ }^{45}$ See Nehaluddin Ahmad "Privacy and the Indian Constitution: A Case Study of Encryption" (1997) 2 (4) AALL Spectrum 8 at 11.
} 
number of constitutional provisions exist where the right to privacy plays a significant role, and that there is, therefore, scope for such a right in art 19(1)(a) and (d) and art 21. ${ }^{46}$

Thus, the protection of privacy developed mainly from this constitutional base, rather than by the courts developing a tort of invasion of privacy, or by extension of the law of breach of confidence as occurred in the United Kingdom. ${ }^{47}$ Case law and judicial pronouncements play a significant role in determining the status of the right in India.

The right to privacy was established by the Supreme Court when dealing with arts 19 and 21 of the Constitution. In Kharak Singh $v$ State of UP \& Ors ${ }^{48}$ the petitioner was put under surveillance in accordance with reg 236 of the UP Police Regulations. The court held that domiciliary visits violated art 21 and were unconstitutional. The majority found that though the Constitution contained no explicit guarantee of a right to privacy, the right to personal liberty was sufficiently expansive to include a right to dignity.

The judgment by Justice Subba Rao in this case was important as it paved the way for the expansion and elaboration of the right to privacy drawn from art 21. The judge defined personal liberty, as the right of an individual to be free from restrictions or encroachment on his person whether these are directly imposed or indirectly brought about by calculated measure. ${ }^{49}$ Thus, personal liberty in art 21 includes all varieties of freedom except those included in art 19. The judgment reveals that the right to privacy exists and unlawful invasion

\footnotetext{
${ }^{46} \mathrm{At} 11$. Articles 19(1), (2) on the protection of certain rights regarding freedom of speech, etc and 21 on the protection of life and personal liberty.

${ }^{47}$ Since Douglas v Hello [2001] 2 All ER 289, Wainwright v Home Office [2002] 3 WLR 405, A v B plc [2002] 2 All ER 545 and Campbell v MGN Ltd [2003] 1 All ER 224, the English courts have protected privacy rights through developing the action for breach of confidence and balancing the competing rights under the European Convention via the Human Rights Act 1998.

${ }^{48}$ [1963] AIR 1295, [1964] SCR (1) 332 (Kharak Singh).

${ }^{49}$ At 334-335.
} 
of privacy is a justifiable cause of action which would render the offender liable for the consequences. It showed the existence of a constitutional recognition of the right to privacy which protected personal privacy against unlawful government invasion (eg surveillance).

The court was of the opinion that the right to privacy in any event would necessarily entail a process of case by case development. Even assuming that the right to personal liberty, the right to move freely throughout India, and the right of freedom of speech create an independent right of privacy which may be characterised as a fundamental right, the right is not absolute. It must, therefore, be subject to restriction on the basis of compelling public interest. ${ }^{50}$ This case marked 'non absoluteness' as the central defining feature of the right to privacy. ${ }^{51}$

$R$ Rajagopal $v$ State of Tamil Nadu ${ }^{52}$ involved a petition concerning the freedom of press in relation to the right to privacy of Indian citizens and the parameters of the right of the press to criticise and comment on the acts and conduct of public officials. The case confirmed that the right to privacy had acquired constitutional status in India. Jeevan Reddy $\mathbf{J}$ referred both to Kharak Singh and Govind and also considered a large number of American and English cases. The judge finally concluded that the right to privacy is implicit in the right to life and liberty guaranteed to the citizens of India by art 21, that is, the right to be let alone. A citizen has a right to safeguard his own privacy as well as his family, his marriage and other concerns such as procreation, motherhood, child-bearing and education. ${ }^{53}$

\footnotetext{
${ }^{50}$ Govind $v$ State of Madhya Pradesh [1975] (3) SCR 946 at 956 (Govind).

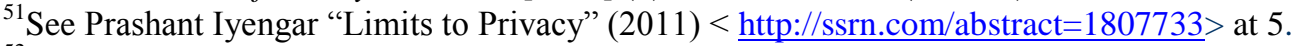

${ }^{52}(1994) 6$ SCC 632.

${ }^{53}$ At [26].
} 
Telephone tapping was discussed in People's Union for Civil Liberties $v$ Union of India. ${ }^{54}$ The issue was whether wiretapping was an infringement of a citizen's constitutional right to privacy. Kuldip Singh J delivered the judgment and provided a broad overview of the development of the right to privacy as a constitutional right and held that telephone tapping was definitely an infringement of privacy and ought not, therefore, to be permitted except in grave circumstances such as a public emergency. The court's observation showed that the right to privacy was not absolute but was determined by each case brought before the court. ${ }^{55}$

The above cases illustrate that the right to privacy in India is a limited rather than an absolute right. For example, the importance of "public interest" is the paramount consideration in determining whether a person is guaranteed an implicit constitutional right to privacy. In $M r . X v$ Hospital $Z,^{56}$ a person sued a hospital for having disclosed his HIV status to his fiancée without his knowledge resulting in their wedding being called off. The Supreme Court held that the hospital was not guilty of a violation of privacy since the disclosure was made to protect the public interest. While affirming the duty of confidentiality owed to patients, the court ruled that the right to privacy was not absolute and was "subject to such action as may be lawfully taken for the prevention of crime or disorder or protection of health or morals or protection of rights and freedom of others."

Significantly, the Indian courts developed the right to privacy in cases of seizure and search or telecommunications surveillance. However, the case of Naz. Foundation v Government of NCT of Delhi ${ }^{57}$ did not involve search and surveillance issues. The case was brought by an NGO, the Naz Foundation, to challenge the constitutional validity of s 377 of the Indian Penal Code which

\footnotetext{
${ }^{54}(1997) 1$ SCC 318.

${ }^{55}$ At [19].

${ }^{56}(2003) 1$ SCC 500 (SC).

${ }^{57}$ WP(C) No. 7455/2001 (2 July 2009).
} 
penalises intercourse against the order of nature with any man, woman or animal. It was argued by the petitioners that s 377 unreasonably abridged the right of privacy and dignity within the ambit of right to life and liberty under art 21 since both rights are recognised as dimensions of art 21 in the Indian Constitution.

The court found that s 377, which denies a person's dignity and criminalises the core identity solely on account of sexual misconduct, violated arts 14,15 and 21 of the Constitution in so far as it severely affected the rights and interests of homosexuals and impaired their dignity. Thus, the $\mathrm{Naz}$ Foundation case demonstrates that the protection of privacy under the Indian Constitution extends beyond issues of search and surveillance. ${ }^{58}$

It is hoped this judicial development will broaden the scope and application of constitutional protection of privacy in the future. This is expressed in Vishaka $v$ State of Rajasthan: ${ }^{59}$

if the legislature fails to meet the need of the hour, the courts may intervene and fill in the vacuum by giving proper directions. These directions would be binding and enforceable in law until suitable legislation is enacted to occupy the field.

The constitutional right to privacy therefore, will continue to develop through judicial interventions so long as there is no specific legislation to address this issue. The right as it existed in India was a limited rather than an absolute one by reason of its lack of explicit constitutional recognition. However, the court's interpretation and commitment in expanding the personal liberty clause to include the right to privacy should not be ignored in deciding local

\footnotetext{
${ }^{58}$ See Graham Greenleaf "The Naz Foundation Case: Delhi High Court Ruling Expands India's Constitutional Privacy Rights" (2009) 100 Privacy Laws \& Business International Newsletter, 24-25.

${ }^{59}(1997) 6$ SCC 241 (Vishaka).
} 
cases. Indeed, the development that has taken place provides the contour of the future shape of privacy law in India.

It is clear, however, that the person's "right to be let alone" is not an absolute right and may be lawfully restricted for the prevention of crime, disorder or protection of health or morals or protection of rights and freedom of others. In Govind v State of Madhya Pradesh ${ }^{60}$ the petitioner challenged the validity of the regulations which provided for police surveillance of habitual offenders including domiciliary visits and picketing. ${ }^{61}$ The court observed that in construing the right to privacy under art 21 , a caution had to be entered in order to avoid a strong judicial reliance on a right that is not explicit in the Constitution.

The absence of specific legislation on privacy and the non-express recognition of its right in the Constitution leave the door open for the court to develop the right through judicial activities. The obiter in Sivarasa should pave the way for the development of the right to privacy within constitutional guarantees. It is strongly believed that the jurisprudential basis initiated by Sivarasa will further Malaysia's continued development of the right to privacy. The similarity of the wording of the Constitutions of India and Malaysia on the protection of life and personal liberty will greatly influence Malaysia to interpret and widen the scope of the protection to cover the right to privacy.

If Malaysia continues to develop a constitutional protection of privacy on the basis of the personal liberty clause as interpreted by Indian cases, that emerging right will have the status of a guaranteed right and be capable of providing comprehensive protection for privacy as defined in this thesis. It

\footnotetext{
${ }^{60}$ [1975] SCR (3) 946, [1975] AIR 1378 (Govind).

${ }^{61} \mathrm{An}$ act of person or group of people who stand outside a workplace or other venue as a protest or to try to persuade others not to enter during a strike. Refer <http://english.oxforddictionaries.com/definition/picket>.
} 
could cover protection of personal information and protection against intrusion into physical space and bodily integrity.

However, reliance on art 5 to protect privacy interests would be problematic because it is unclear whether Malaysian courts will follow India, and if they do, the question is how expansively Indian courts have interpreted the new right to privacy. It is predicted that any development in this area would be piecemeal and slow. Furthermore, the constitutional protection discussed in Indian cases above only covers interactions between state and individuals.

However, in Vishaka, a case dealing with sexual harassment of working women, the Supreme Court extended constitutional guarantees to provide protection for the aggrieved individual against sexual harassment and to promote gender equality among citizens. Thus, there is a possibility of horizontal effect in art 15 of the Indian Constitution. ${ }^{62}$ On the other hand, direct horizontal application of other fundamental rights to non-state actors poses some difficulties though their indirect horizontal effect remains an option. ${ }^{63}$ In a similar vein, such possibility has been precluded in Malaysia and it is important to note that the effect of the Malaysian Constitution is solely vertical as confirmed by the Federal Court in Beatrice AT Fernandez $v$ Sistem Penerbangan Malaysia: ${ }^{64}$

\begin{abstract}
We found that it is simply not possible to expand the scope of art 8 (equality before law) of the Federal Constitution to cover collective agreement such as the one in question. To invoke art 8 , the applicant must show that some law or
\end{abstract}

\footnotetext{
${ }^{62}$ Article 15 provides on equality before law.

${ }^{63}$ Surya Deva "The State of Affirmative Action amidst Privatisation: Some Critical Reflections" in Swati Deva (ed) Law and (In)equalities: Contemporary Perspectives (Easter Book Company , India, 2010) at 25, 34-35. See also Mahendra P Singh "Fundamental Rights, State Action and Cricket in India" (2006) 13 Asia Pacific Law Review 203 at 204. According to the author, the rationale behind this view is that the definition of state cannot and must not be used for restricting the application of a fundamental right against the state while in its content and nature a right is not so restricted.

${ }^{64}$ [2005] 2 CLJ 713, at 720.
} 
action of the Executive discriminates against her so as to controvert her rights under the said article. Constitutional law, as a branch of public law, deals with the contravention of individual rights by the Legislature or the Executive or its agencies. Constitutional law does not extend its substantive or procedural provisions to infringements of an individual's legal right by another individual.

Having said that, an alternative possibility of protecting privacy interests may be through the application of existing common law principles. This is discussed in the next part.

\section{Existing Common Law Principles for the Protection of Privacy}

In Malaysia, there is no general right to privacy and thus, no actionable tort of privacy. The courts are obliged to consider other tort principles when giving judgment in cases involving breaches of privacy. ${ }^{65}$ Similarly, in the UK, the court will refer to existing causes of action rather than formulate a new liability in tort. ${ }^{66}$ Thus, an important question arises which is to what extent do existing current law protections protect privacy as defined in this thesis? In this Part, existing common law principles are explored in order to evaluate their adequacy and applicability to accommodate privacy interests and to provide protection against infringements. ${ }^{67}$

\footnotetext{
${ }^{65}$ See Ultra Dimension Sdn Bhd v Kook Wei Kuan [2004] 5 CLJ 285 (HC). The court held that the publication of the photograph in the advertisement did not give the respondent a cause of action as the facts of the case did not fall within the boundaries of any recognised and existing tort. Furthermore, privacy was not a recognised right under the Malaysian law.

${ }^{66}$ See Kaye v Robertson [1991] FSR 62 (Kaye).

${ }^{67} \mathrm{See}$ also discussion of common law principles and protection of privacy-related interests in Haidar Dziyauddin "A Commparative Study of Freedom of Expression and Right to Privacy in Relation to the Press in Malaysia and the United Kingdom" (PhD Thesis, University of Newcastle Upon Tyne, 2005), at 219-224.
} 
Common law principles such as defamation, nuisance, trespass and breach of confidence are widely applicable to protect aspects of privacy. These principles do not provide direct protection of privacy. Instead they provide necessary protection to interests related to privacy involving private facts, reputation, infliction of harm and proprietary interests.

\section{A Defamation}

The law of defamation protects a person's reputation against unjustifiable attack. It aims at giving protection to a person from being brought into disrepute. It seeks to protect a personal dignity and honour. Thus, the interest that is protected by this tort is a person's good name and reputation. ${ }^{68}$ In an action for defamation ${ }^{69}$ whether for libel or slander, the plaintiff must prove that the matter complained of: ${ }^{70}$

(i) is defamatory;

(ii) refers to the plaintiff;

(iii) has been published to a third person.

Defamation is actionable when there is a publication that causes a person to be ridiculed by right thinking members of the public or to lower a person in the public estimation or to be avoided by reasonable persons in society thus affecting that person's reputation. The action could possibly be relevant to victims of breach of privacy to the extent that the publication involves private facts. In Tun Datuk Patinggi Haji Abdul Rahman Ya'kubv Bre Sdn Bhd \& Ors $^{71}$ Richard Malanjum J followed JB Jeyaretnam v Goh Chok Tong ${ }^{72}$ and adopted the following approach:

\footnotetext{
${ }^{68}$ See also Norchaya Talib Law of Torts in Malaysia (Sweet \& Maxwell Asia, Malaysia, 2010), at 263.

${ }^{69}$ In Malaysia, apart from common law principles, actions relating to the law of libel and slander and other malicious falsehoods are governed by the Defamation Act 1957 which is in pari materia with the Defamation Act 1952 (UK).

${ }^{70}$ Norchaya, above n 68, at 273.

${ }^{71}$ [1996] 1 MLJ 393.
} 
As to whether the words complained of in this case were capable of being, and were, in fact, defamatory of the plaintiff, the test to be considered is whether the words complained of were calculated to expose him to hatred, ridicule or contempt in the mind of a reasonable man or would tend to lower the plaintiff in the estimation of right-thinking members of society generally.

If the fact that was published were true, that would serve as a complete defence. This makes the law of defamation inappropriate for the protection of privacy because invasion of privacy is mainly about public revelation of personal information regardless of its veracity. In addition, if the comment is an honest one based on facts, a qualified defence for defamation exists. In the nature of the action, defamation strikes at the essence of privacy, which is a person's dignity. The tort involves injury not to an individual per se, but rather to an individual's reputation as perceived by others in the community.

In Dato' Seri Anwar Ibrahim v The New Straits Times Press (M) Sdn Bhd \& Anor $^{73}$ the plaintiff brought an action for defamation in relation to an article published in the newspaper under the caption “Anwar's link to US lobbyist New Revelation" by a political weekly magazine. The plaintiff claimed that the article defamed him and sought general damages of RM100m as well as aggravated and exemplary damages. The court held that the effect of the article lowered the plaintiff in the estimation of ordinary, right-thinking members of Malaysian society and, therefore, the article was defamatory. The judge also commented on the test of "shunned and avoided" in determining whether or not the words were defamatory: ${ }^{74}$

\footnotetext{
${ }^{72}$ [1985] 1 MLJ 334. This approach was discussed in Shaharuddin bin Mohammad v Malayan Banking Bhd [2011] 7 MLJ 589 to the effect that the publication of a notice in that case was pursuant to a court order and therefore any defamatory imputation in the notice was justified and gave rise to no liability in defamation, at [13]. ${ }^{73}[2010] 2$ MLJ 492 (HC).

${ }^{74}$ At [19].
} 
The test, however, does provide some incidental protection against unwarranted privacy invasions which in any case ought to be provided by a specific legislation [sic] on privacy rather than a reliance on defamation law.

To protect privacy through defamation law is unrealistic as an invasion of privacy may be more than an attack on reputation. Its aims are different and the relief to be provided is also different. The law of defamation should be strictly confined to the protection of reputation. However, invasion of privacy occurs when there is unwanted access to information or unauthorised publication of private facts. In this situation, if a person publishes B's photograph with her boyfriend in a magazine, B may not take an action of defamation because the photograph is not defamatory and does not lower B's reputation. In fact, however, B's personal information was published without permission, and thus an action of the invasion of privacy is applicable.

Similarly, in Kaye, an injunction was sought to restrain the publication of photographs and an alleged interview. Although the English Court of Appeal recognised that there had been an invasion of privacy, the law of defamation could not provide the grounds for the grant of an injunction. ${ }^{75}$

The above observation illustrates that the law of defamation is not capable of providing protection for invasions of privacy. Though defamation has in some cases protected an interest akin to privacy, it is inadequate to protect privacy generally.

\section{B Trespass}

The law of trespass aims at the protection against interference of person, interests in land and goods. Any person who enters or gains access to land,

\footnotetext{
${ }^{75}$ See Harmindar Singh Dhaliwal "Tests of Defamatory Matter- New Mindset Required?" (2003) 2 MLJ i.
} 
goods or a person may be liable in trespass. Trespass to the person includes assault, battery and false imprisonment. Assault is concerned with the protection of a person's mental well-being against the unlawful act of another ${ }^{76}$ an action for battery protects an individual from any interference with his person, thus preserving a person's dignity as well as reputation. ${ }^{77}$ If, therefore, a reporter creates an apprehension of danger in the course of obtaining news or photographs, an action of assault may arise which may lead to battery if force is applied to the body of a person without that person's consent or without other lawful justification in the course of acquiring the information. Both actions of assault and battery indirectly protect against breaches of privacy by intrusion.

As discussed in Chapter Two, individuals lose privacy when others gain physical access to them. ${ }^{78}$ A person is said to be physically inaccessible if she cannot be experienced through one of the five senses. ${ }^{79}$ Thus, if A installed a video camera in B's room without B knowing of its existence, A has gained access to B's room for the purpose of recording B's activities. In this example, assault and battery are not appropriate actions because there is no apprehension of danger and the incident occurs without any application of force to B's body. It is, however, an intrusion into private space and bodily integrity that could only be protected by a privacy action.

Trespass to land occurs when a person unjustifiably enters onto land in the possession of another. It is an interference with possession of land ${ }^{80}$ It is

\footnotetext{
${ }^{76}$ Norchaya, above $\mathrm{n} 68$ at 12.

${ }^{77}$ At 14. The author referred to Collins $v$ Wilcock [1984] 1 WLR 1172 at 1177. Robert Goff LJ said that "the fundamental principle, plain and incontestable, is that every person's body is inviolate except in situations where the bodily contact falls within a general exception embracing all physical contact which is generally acceptable in the ordinary conduct of daily life."

${ }^{78}$ Gavison, above ch 2, n 28 .

${ }^{79}$ Allen, above ch $2, \mathrm{n} 1$.

${ }^{80}$ Sin Heap Lee-Marubeni Sdn Bhd v Yip Shou Shan [2005] 1 MLJ 515, the judge held that, the trespass committed by the appellant was a continuing act of trespass from the time when the respondent was not in the possession of the land to the time he came into possession of the
} 
actionable per se, without proof of special damage. Its main purpose is to protect proprietary interests. Nevertheless, it provides an indirect protection of privacy-related interests whereby the interest in land, by way of possession, cannot be interfered with. Those in the possession of the land may bring an action of trespass if a reporter or photographer enters land to conduct an interview or take photos or film activity within the boundaries of the land. However, the right of a landowner to the land is limited, for an action could not be upheld for photos taken from off the land or from the airspace above it. In Lord Bernstein of Leigh $v$ Skyviews and General Ltd ${ }^{81}$ the court held that there was no trespass committed by the defendant who took a picture of the plaintiff's premises. Griffiths J said: ${ }^{82}$

The problem is to balance the rights of an owner to enjoy the use of his land against the rights of the general public to take advantage of all that science now offers in the use of airspace. This balance is ...best struck... by restricting the rights of an owner in the airspace above his land to such height as is necessary for the ordinary use and enjoyment of his land and the structures on it, and declaring that above that he has no greater rights in the airspace than any other member of the public.

The exclusive use and enjoyment of land and airspace is partially a privacy interest. It means that a person is entitled to an absolute enjoyment of and freedom from unwanted or unauthorised access to the land. Section 44(1)(a) of the National Land Code 1965 (NLC) gives the registered owner of the land the exclusive use and enjoyment of so much of the column of airspace above the surface of the land, and so much of the land below that surface, as is reasonably necessary to the lawful use and enjoyment of the land. In Chen Yue

land and in fact continuing after he came into possession of the said land. Other cases see also Karuppannan v Balakrishnen (Chong Lee Chin, Third Parties) [1994] 3 MLJ 584 and Julaika Bivi v Mydin [1961] MLJ 310.

${ }^{81}$ [1977] 2 All ER 902.

${ }^{82}$ At 907. 
Kiew $(F)$ v Angkasamas $S d n$ Bhd the court found that a landowner is entitled to exclusive use of the land and the air space above the land. Even though the intrusions onto the respondent's land by the appellant appeared trivial to the appellant; it could not be denied that they constituted a clear breach of the respondent's right to the exclusive use and enjoyment of his land. The court did not hesitate to grant a perpetual injunction against anyone trespassing on the land of another or into the air space above it. ${ }^{83}$ Trespass to land can protect intrusion into private space or property, but is limited by the NLC.

Again, the issue of an exclusive enjoyment of property was discussed in $K$ Mahunaran $v$ Osmond Chiang Siang Kuan. ${ }^{84}$ In that case, the plaintiff and the defendant were owners of the two premises comprised double-storey terrace houses separated by a common wall. The defendant concreted the wall at the front portion of the premises without the consent of the plaintiff. The plaintiff applied for an order for the defendant to pull down and remove the wall put up by him and to restore it to its original position or as close to that as possible. The plaintiff also alleged that the said construction had impeded his light, ventilation and view. The court decided that the defendant had committed an act of trespass by demolishing the original wall and building a new wall. In this situation, the right of individual over the land was denied, and, therefore, was a denial of exclusive use and enjoyment of the land as granted by the law.

As far as an action in trespass to land is concerned, it neither protects privacy interests in information nor the self; it rather protects an individual's proprietary interests to an exclusive use and enjoyment of his land. Thus, the owner of the land has absolute control over his land and is capable of excluding unauthorised access to it, but an action in trespass does not protect any subsequent conduct that breaches the privacy of the land owner.

\footnotetext{
${ }^{83}$ Chen Yue Kiew (F) v Angkasamas Sdn Bhd [2003] 4 MLJ 365. However, there was no privacy rationale articulated in this case, as it purely involved an action in trespass to land. See also Karuppannan v Balakrishnen (Chong Lee Chin \& Ors, third parties) [1994] 3 MLJ 584.

${ }^{84}[1996] 5$ MLJ 293.
} 


\section{Nuisance}

A cause of action in nuisance also provides indirect protection of privacy. The purpose of the law of nuisance is to provide comfort to persons who have proprietary interests in land, and to members of society generally, through control of environmental conditions. ${ }^{85}$

Malaysian courts have followed the law of nuisance as developed by the English courts. The tort of nuisance was considered in Hunter $v$ Canary Wharf $L t d^{86}$ where Lord Lloyd stated that private nuisance basically involved three situations namely, nuisance by encroachment on a neighbour's land, nuisance by direct physical injury to a neighbour's land, and nuisance by interference with a neighbour's quiet enjoyment of the land. Thus, nuisance is relevant when it involves interference with enjoyment of the land or "the personal inconvenience and interference with one's enjoyment, one's quiet, one's personal freedom and anything that discomposes or injuriously affects the senses or the nerves". ${ }^{87}$ Clark \& Lindsell submitted that it is always a question of degree to determine whether the interference with comfort or convenience is sufficiently serious to constitute a nuisance. Circumstances such as time, place, extent or manner of performance determine whether lawful activities such as sounds, smells or vibration constitute a nuisance. ${ }^{88}$

The court in Ong Koh Hou v Perbadanan Bandar \& Anor ${ }^{89}$ observed that it is a question of fact whether or not a nuisance is committed. The primary consideration in a nuisance case is the question of reasonableness in which reference to all circumstances of the case: the time and place of commission,

\footnotetext{
${ }^{85}$ Norchaya, above $\mathrm{n} 68$, at 327.

${ }^{86}$ [1997] 2 All ER 426.

${ }^{87}$ Anthony M Dugdale Clark \& Lindsell on Torts (18th ed, Sweet \& Maxwell, London, 2000) at 979 [Clark \& Lindsell on Torts] as cited in Ong Koh Hou v Perbadanan Bandar \& Anor [2009] 8 MLJ 616 (HC).

${ }^{88}$ At 979 .

${ }^{89}[2009] 8$ MLJ 616 (HC).
} 
the seriousness of harm, the manner of committing it and, the effect of its commission that is whether it is continuous or not. These are the determining factors for an actionable nuisance which must seriously interfere with the comfort or convenience of the living standards of the average person. ${ }^{90}$

The English court in Halsey v Esso Petroleum Co $\mathrm{Ltd}^{91}$ held that loud noises and vibration interfere with one's enjoyment, one's quiet, one's personal freedom, and anything that disturbs or injuriously affects the senses or the nerves. ${ }^{92}$ The judgment was followed in Azman Bin Mohd Yussof \& Ors $v$ Vasaga $S d n$ Bhd, ${ }^{93}$ in which the court stated that the loud music from the defendant's premises caused vibration to the plaintiff's building and others. The court held that interference with the enjoyment of property includes unreasonable noise or vibration.

In situations discussed above, the law of nuisance offers indirect protection to privacy, although limited in its application, because invasion of privacy has essentially nothing to do with interests in land. If the defendant's action does not unlawfully interfere with the plaintiff's use or enjoyment of the land or some right over or in connection with it, the tort of nuisance is not applicable. However, privacy may be invaded if there is unlawful interference with the use and enjoyment of the land when access is gained, and subsequently the owner's personal information is published. In this instance, the law of nuisance does not provide adequate protection to the owner.

\footnotetext{
${ }^{90}$ At [11] and [13]. See also Clark \& Lindsell on Torts, above $\mathrm{n} 87$. ${ }^{91}$ [1961] 1 WLR 683.

${ }^{92}$ See Clark \& Lindsell on Torts, above $\mathrm{n} 87$.

${ }^{93}$ [2001] 6 MLJ 217. See also IJM Corporation Bhd v Harta Kumpulan Sdn Bhd [2007] 8 MLJ 591 (HC), where the court expressed the view that nuisance is the tort of unlawful interference with a person's enjoyment or use of land. If a person sends deliberate harassing and pestering letters to another, such an act would also amount to an interference with the recipient's enjoyment of land and therefore constitute an actionable nuisance.
} 
The law on trade secrets and confidential information could provide means for the protection of privacy in Malaysia. The protection of trade secrets and confidential information is broadly based on the common law principle of breach of confidence. The law of breach of confidence seeks to protect confidential information from unauthorised use or unlawful disclosure - an aspect of privacy. Currently, Malaysia adopts the common law principles of confidentiality as applied by the UK courts. For example in Worldwide Rota Dies Sdn Bhd $v$ Ronald Ong Cheow Joon, ${ }^{94}$ the court found that (a) the information which the plaintiff sought to protect was of a confidential nature; (b) that the information in question was communicated in circumstances importing an obligation of confidence; and (c) that there was an unauthorised use of that information to the detriment of the party communicating it. The court was satisfied that all the three elements in Coco $v$ A $N$ Clark (Engineers) $L t d^{95}$ existed and granted an injunction against the defendants.

An action for breach of confidence is not limited to circumstances where there is a contractual relationship. The scope of the law was widened when the court recognised that breach of confidence was one of the actions in tort. ${ }^{96}$ Kamalanathan Ratnam JC in Schmidt Scientific Sdn Bhd v Ong Han Suan ${ }^{97}$ when deciding the issue of disclosure of confidential information or trade secrets by an ex-employer, stated that a breach of confidence should also be

\footnotetext{
${ }^{94}[2010] 8$ MLJ 297.

${ }^{95}$ [1969] RPC 41 (Coco).

${ }^{96}$ However, under the English law an action for breach of confidence was founded on equitable doctrine of confidence. See Prince Albert v Strange (1849) 2 De G \& Sm 652. See also Coco at 46, where Megarry J suggested that the origin of the action for breach of confidence lay in the earliest operations of the court of Chancery, but had been obscured until in the middle of the last century, the great case of Prince Albert $v$ Strange...reasserted the doctrine. In Douglas v Hello! Ltd (No 3) [2003] 3 All ER 996 at [181], Lindsay LJ said "At the broadest level of generality it can be said that equity offers remedies where a breach of an appropriate confidence, personal or commercial, is threatened or has occurred. There is nothing new about the availability of remedies in either type of confidence."

${ }^{97}[1997] 5$ MLJ 632 (HC).
} 
regarded as a tort with an award of damages if the claim was successful. According to him, since the categories of tortious liability remain open, the ingenuity and resourcefulness of the human mind can and ought to lead to fresh categories of tort being established, and this could include a tort for breach of confidence. ${ }^{98}$

Looking at the court's practice in breach of confidences cases so far, there is no potential for the breach of confidence action to provide protection against breach of privacy. What is protected by the action is "confidential information" and the doctrine has not extended the protection to privacy. The courts have been unwilling to move beyond the requirements of the action as articulated in Coco, and the action is only applied in the commercial context. Therefore, the utilisation of breach of confidence action for privacy protection is unlikely to happen in Malaysia.

The above-mentioned cases show that legal protection of privacy-related interests is available in Malaysia. However, legal protection is not accorded to privacy per se. Protection of privacy interests in Malaysia is indirect and piecemeal.

The discussion in this part illustrates that even when taken together the actions described do not protect privacy adequately. An analysis of the common law principles shows that though aspects of privacy may possibly be protected by the established tort principles, they fail to provide remedies in the context of the theoretical framework of privacy advanced by this thesis. Protection of privacy is desirable when there is unwanted access to the physical body as well as to personal information. It is argued that the lack of the protection

\footnotetext{
${ }^{98}$ The court referred to statement made by Lord Denning MR in Seager v Copydex Ltd [1967] 2 All ER 416 that equity would interfere to prevent those receiving information in confidence from taking unfair advantage of it and decided that a breach of confidence should also be regarded as a tort with damages to be awarded to the successful plaintiff.
} 
offered by the existing common law principles needs to be remedied through constitutional measures, particularly explicit rights in the Constitution. ${ }^{99}$

The continuing observation of privacy matters by the court in Malaysia that may lead to the development of the right to privacy through judicial activities is the subject of the following discussion.

\section{Judicial Development of the Right to Privacy}

Section A below considers the current position of privacy in tort law, and its development from 2004. The importance of judicial developments requires a detailed discussion of certain cases. In section $\mathrm{B}$, the limited references to privacy in pre-2004 cases will be discussed to show that privacy was considered when reaching a judgment. The constitutional developments of the right to privacy, particularly in Sivarasa, were discussed in Part III (B)(3).

\section{A Tort Cases}

Since 2006, a few tort cases have suggested a shift towards acknowledging privacy as a right in Malaysia. The position has radically changed during that period and is now moving towards the establishment of a privacy right in the Constitution and its recognition as a cause of action in private law.

\section{$1 \quad$ Denying the existence of the tort}

In 2004, hesitation to recognise the right to privacy was illustrated by the High Court decision in Ultra Dimension Sdn Bhd $v$ Kook Wei Kuan, ${ }^{100}$ a case

\footnotetext{
${ }^{99}$ See also Ida Madieha Azmi "Personal data protection law: The Malaysian experience" (2007) 16(2) Information \& Communications Technology Law 125 at 129 in which the author observed that the minimalist legal framework on data privacy and the delay in passing a comprehensive law on the same would have to be measured against the treatment of the broader right to privacy in Malaysia, particularly from the constitutional perspective.
} 
against the appellants who took a photograph of a group of pupils at an open area outside their kindergarten and published it in two local newspapers with the caption "Bonus Link Share Your Points". The issue was whether or not the picture amounted to invasion of privacy and breach of confidence. It was claimed that supplying of the photograph for an advertisement had invaded the respondent's privacy. However, the court found that the publication of the photograph in the advertisement did not give the respondent a cause of action as the facts of the case did not fall within the boundaries of any recognised and existing tort. Having referred to the English court decision in Kaye, the court held that the privacy right was not recognised under the Malaysian law.

The decision in Kaye was referred to in this case by virtue of s 3 of the Civil Law Act $1956 .{ }^{101}$ The court also made an observation that a cause of action for privacy may arise only if photographs are highly offensive in nature and show a person in an embarrassing position or pose. The photograph involved in the instant case was not offensive in nature because it merely showed a group of kindergarten pupils in cheerful mood taken at an open area outside the kindergarten, and there was no publication of any information relating to the respondent in the advertisement. It was used for a decent purpose: An advertisement for Bonuslink cards.

It is worth considering the judge's remarks. Faiza Tamby Chik J concluded that "privacy rights" are "the right to be left alone" and "to live free from all intrusions by others" as defined by Nicholas J Mullany, ${ }^{102}$ is different from the right to "Life" and "Personal Liberty" which may be interpreted as enjoyment of life and the freedom of an individual to move and engage in any

\footnotetext{
${ }^{100}$ [2004] 5 CLJ 285 (HC) (Ultra Dimension).

${ }^{101}$ Section 3(1)(a) of the Civil Law Act 1956 provides for the application of the English common law and the rules of equity in West Malaysia. See above, Part II.

${ }^{102}$ Nicholas J Mullany Torts in the Nineties (LBC Information Services, Sydney, 1997) at $\mathrm{p}$ 176.
} 
activities (which do not contravene the laws) without hindrance or obstacles as defined in art 5 of the Federal Constitution. ${ }^{103}$

In fact, the case provided an opportunity for the court to develop judicial recognition of the right to privacy. However, due to a heavy influence of the English common law and the court's reluctance to uphold a new head of liability, it simply followed development in the UK by reason of the applicability of ss 3 and 5 of the Civil Law Act 1956. The judgment was based on questionable grounds. First, Malaysia has a written constitution that safeguards the fundamental rights and freedom of its subjects. When the Constitution is silent on a matter, then subsequent sources of law are to be considered. ${ }^{104}$ In reaching the judgment, the judge went straight to s 3(1) of the Civil Law Act 1956 and applied the common law principle to the matter. Following the hierarchy of the sources of law, a judge in formulating judgment should first determine the existence of any written law in Malaysia. Before any reference to English cases is made this route is mandatory. Gopal Sri Ram JCA said: ${ }^{105}$

\begin{abstract}
It is wholly unnecessary for our Courts to look to the Courts of England for any inspiration for the development of our jurisprudence on the subject under consideration. That is not to say that we may derive [sic] useful assistance from their decisions. But we have a dynamic written Constitution and our primary duty is to resolve issues of public law by having resort to its provisions.
\end{abstract}

\footnotetext{
${ }^{103}$ Article 5(1) provides the deprivation of life and personal liberty save in accordance with law.

${ }^{104}$ In Malaysia, the Federal Constitution is the first source of laws followed by the respective States' Constitutions; the Acts of Parliament (Federal Laws including Ordinances as may be appropriate); the State Enactments; then cases law duly decided by the superior courts (decision of courts of higher level binds the court subordinate to it). Such tiers are binding upon the courts in Malaysia.

${ }^{105}$ Tan Tek Seng, above n 35, at [41].
} 
Another argument is that s 3(1) provides for the importation of English common law by the cut-off date in Peninsular Malaysia of 7 March 1956, but the application of the English common law after the date has a persuasive authority only. ${ }^{106}$ It is awkward that the judge followed the English precedent that did not represent common law as it had developed to 2004 and that she failed to note the passing of the Human Rights Act 1998. Kaye was an odd case to rely on in 2004 considering the development of breach of confidence action and Douglas v Hello! which significantly altered the English legal landscape in protecting privacy.

Following Ultra Dimension, the High Court in Dr Bernadine Malini Martin v MPH Magazines Sdn Bhd \& Ors ${ }^{107}$ confirmed that an invasion of privacy was not an actionable wrong. In this case, the plaintiff who was a government medical officer brought an action against the defendants for the tort of defamation. She alleged that the publication of her photograph in a bridal gown together with a write-up without her consent was defamatory, and alleged that the advertisement portrayed her as a woman of loose morals and an unsuccessful doctor who resorted to part-time modeling to supplement her income. In his judgment Hishamudin Yunus $\mathrm{J}$ acknowledged that the unauthorised publication of the plaintiff's photograph in a magazine was intended for public circulation and that it was unethical and morally wrong of the defendants to have published it without her consent for the purpose of their commercial promotion. It was, he found, an unwarranted invasion of the plaintiff's privacy. However, unfortunately for the plaintiff, as the law of this country stands presently, an invasion of privacy is not an actionable wrongdoing. ${ }^{108}$

\footnotetext{
${ }^{106}$ Reference to the law in England after the cut-off date does not have any binding effect in Malaysia. See The Malaysian Legal System, above n 13.

${ }^{107}[2006] 2$ CLJ 1117 (Lew Che Phow).

${ }^{108}$ At [50].
} 
In 2011, the High Court in Lew Cher Phow @ Lew Cha Paw \& Ors v Pua Yong Yong \& Anor ${ }^{109}$ recognised a right to privacy and held that the right to privacy of the plaintiffs should be protected. Although it was a High Court judgment and subject to review by higher courts, it has opened a new dimension in developing the right to privacy in Malaysia.

The case concerned the issues of private nuisance and breach of the right to privacy. The plaintiffs and defendants were neighbours whose houses were separated by zinc sheets only. Disagreement arose between them and their relationship deteriorated. One of the plaintiffs was charged and convicted of criminal intimidation against the defendants. Sometime later, the defendants installed five CCTV cameras in their house. Camera (no 3) was located at the front porch and pointed directly at the plaintiffs' house capturing and monitoring images of their front courtyard. The plaintiffs brought an action claiming that their right to privacy had been infringed.

The court found that privacy in the present case was related to a person's right to respect for his private and family life and his home. The fact that there is no specific provision in the Constitution guaranteeing the right to privacy does not preclude a court from holding that such a right exists because privacy is recognised as a fundamental human right internationally, given recognition by international covenants, treaties and regional human rights treaties. The defendants' continuing act of putting the plaintiffs under surveillance represented a failure of respect for the plaintiff's dignity and autonomy. It constituted an intrusive surveillance on the plaintiffs' private and family life and home. The defendants' fear for their safety and security did not justify their actions and did not override the plaintiffs' right to privacy. Continuous CCTV surveillance by the defendant was an unwarranted violation of the

${ }^{109}$ [2011] MLJU 1195 (HC). 
plaintiffs' right to privacy. Thus, the plaintiffs were entitled to protection even though the invasion did not cause actual or pecuniary damage. An injunction to restrain the defendants from installing any CCTV directed at the plaintiff's house was granted. ${ }^{110}$ The court also acknowledged that the views presented in Ultra Dimension were out of date considering new emerging trends and changing societal conditions.

The question as to whether a cause of action for violation or invasion of privacy rights is actionable under the law of tort had been confirmed in the earlier case of Lee Ewe Poh v Dr Lim Teik Man \& Anor. ${ }^{111}$ There, the plaintiff brought an action against the first defendant who took photographs of her private parts during the Stapler Haemorrhoidectomy procedure. She claimed that taking the photographs was a violation of her privacy and dignity as it was done without her consent. The court referred to Maslinda Ishak which held that in Malaysian common law privacy is an actionable cause of action and accepted as a cause of action thus permissible for a plaintiff to found her action. On the nature of privacy, the court stated that the privacy of a female in relation to her modesty, decency and dignity in the context of its high moral value in society is fundamental to sustaining that high morality demanded of her and ought, therefore, to be entrenched. Hence, the plaintiff successfully maintained her claim. Chew Soo Ho JC remarked that: ${ }^{12}$

...modesty and decency of the female patients must be respected and not violated. A failure to do so constitutes an invasion of the plaintiff's privacy or a breach of the trust and confidence that the plaintiff as patient had reposed on her treating doctor.

The situation is the same if it involves a male patient although, of course, different parts of the body would be treated differently depending on the

\footnotetext{
${ }^{110}$ per Vernon Ong J.

${ }^{111}$ [2011] 1 MLJ 835 (HC) (Lee Ewe Poh).

${ }^{112}$ At [15].
} 
gender of the subject. Beyond this, there should be no gender discrimination in treating situations involving privacy. This is confirmed by art 8 of the Constitution on equality:

(1) All persons are equal before the law and entitled to the equal protection of the law.

(2) Except as expressly authorised by this Constitution, there shall be no discrimination against citizens on the ground only of religion, race, descent, place of birth or gender in any law or in the appointment to any office or employment under a public authority or in the administration of any law relating to the acquisition, holding or disposition of property or the establishing or carrying on of any trade, business, profession, vocation or employment.

The refusal to recognise the tort of privacy in Ultra Dimension was not followed in Maslinda Ishak. ${ }^{113}$ Instead the status of an invasion of privacy in Malaysia changed when the Court of Appeal recognised and affirmed it as a cause of action and thus an actionable tort. The plaintiff Maslinda was arrested at a night-club in a joint operation of officers of RELA ${ }^{114}$ and JAWI. ${ }^{115}$ She was put in a truck together with other persons arrested. The plaintiff asked the defendant to use toilet facilities but was refused, scolded and told to urinate in the truck. As she was unable to hold on, she asked her friends to shield her by encircling her with a shawl. At the same time the defendant (an officer of RELA) opened the door, rushed in, pulled down the shawl and took numerous photos of her. Maslinda pleaded that her privacy had been invaded, resulting in humiliation, trauma and serious mental anguish as a result of the defendant's action of photographing her in a squatting position urinating within the view of everyone in the truck.

\footnotetext{
${ }^{113}$ Above n 14.

${ }^{114}$ Pasukan Sukarelawan Malaysia or Malaysian People's Volunteer Corps. It is an agency under the Ministry of Home Affairs whose functions are to ensure local security, the wellbeing of local communities and harmony in the community. Refer http://www.rela.gov.my.

${ }^{115}$ Federal Territory Islamic Affairs Department.
} 
The judge found for Maslinda and held that the issue of invasion of privacy was never under challenge. The High Court in so finding departed from the old English law that invasion of privacy is not an actionable tort. ${ }^{116}$ When the case was brought on appeal, the Court of Appeal indirectly, though the issue was not canvassed, ${ }^{117}$ seemed to endorse such cause of action and did not overrule invasion of privacy as a cause of action on the ground that it was not in line with the English law. ${ }^{118}$

The defendant was subsequently prosecuted and charged under s 509 of the Penal Code which provides that "it is an offence to insult the modesty of any person, utter any word, make any sound or gesture, or exhibit any object, intending that such word or sound shall be heard, or that such gesture or object shall be seen by such person, or intrude upon the privacy of such person". He pleaded guilty and was convicted.

The analysis of recent judgments shows that the Malaysian courts are progressing towards recognition of the right to privacy and providing remedies for infringements. This recognition was achieved in Lew Cher Phow, Maslinda Ishak and Lee Ewe Poh when the courts affirmed invasion of privacy as an actionable tort. However, it is vital to emphasise that these three judgments come from the High Court and the Court of Appeal which are not the highest courts in Malaysia. Further development of the right to privacy can only be determined by future cases.

\footnotetext{
${ }^{116}$ This finding was first upheld in Ultra Dimension, above n 98.

${ }^{117}$ The Court of Appeal has never affirmed expressly that the privacy tort is actionable, but it was understood as such by way of implication when the court did not challenge the issue of invasion of privacy which was decided earlier in the High Court. In fact, the main issue at the Court of Appeal was whether the principal was jointly and severally liable with the wrongful act of an agent acting within the scope of his authority.

${ }^{118}$ Refer per Chew Soo Ho JC in Lee Ewe Poh, above n 109 at 843.
} 


\section{B Other cases}

Historically, privacy was not an unfamiliar concept as it has been mentioned several times in the Malaysian judicial arena. The opportunity to analyse privacy as an issue that needed protection and recognition, however, has never been taken up by the courts. ${ }^{119}$

There are isolated examples of courts recognising the importance of privacy interests in case law. For instance, Public Prosecutor v Lee Sin Long ${ }^{120}$ involved the search of premises. A warrant is required before a search can take place, and the householder may be justified in refusing admission to a police officer in the absence of such a warrant. Callow $\mathrm{J}$ stipulated that "the privacy of a person in his home must be respected, and cannot be disturbed unless first shown proper authority that reasonable cause for interference is warranted". However, there was no further discussion of privacy issues.

In Electrical Industry Workers Union \& Ors v Makonka Electronics Sdn Bhd, ${ }^{121}$ Abdul Wahab JC stated that strict compliance with the undertakings and terms was essential when an Anton Piller order ${ }^{122}$ is granted. The court was aware of the effect of the order on the privacy rights of the defendant but made no further comment on the privacy matter.

The importance of privacy of one's home was again mentioned in $H M O$ Pacific Sdn Bhd v Dr Johari Bin Muhamad Yusup ${ }^{123}$ in which Rekhraj JC that the Anton Piller order as one of the law's "nuclear weapons" which is to "be

\footnotetext{
${ }^{119}$ See Hurriyah El Islamy "Privacy as Freedom of Private Life: The Re-examination of the Concept, the Scope and Its Analysis and Comparison with the Law of Confidence in the United Kingdom and Malaysia" (PhD Thesis, University of Strathclyde, 2006). The author stated that reference to privacy as a right in Malaysia has been taken for granted and had not been given due consideration. She mentioned a few cases that are discussed in this section. ${ }^{120}$ [1949] 1 MLJ 51 at [13].

${ }^{121}[1996]$ MLJU 387 (HC).

${ }^{122}$ It is a mandatory order to preserve material documentary evidence, see Anton Piller $K G v$ Manufacturing Processes Ltd [1976] 1 Ch 55.

${ }^{123}$ [1997] MLJU 286 (HC).
} 
very sparingly resorted to in very special and rare circumstances; as the relief sought erodes the right to sanctity and sanctuary to a privacy of one's own home".

These cases show that the importance of privacy was considered when giving judgment. Nevertheless they did not directly determine the issues or the meaning of privacy.

\section{Conclusion}

Discussion of the existing protection for privacy in Malaysia shows that the protection available in various sources of law in Malaysia is inadequate to offer a comprehensive safeguard to the right to privacy, and insufficient to provide remedies to the victim of an invasion of privacy.

Constitutional protection and relevant common law principles have indirectly provided elements for the protection of the right; however, the nature and coverage of each law is not complete and does not conform to the concept of privacy advanced by this thesis.

Future opportunities to develop a constitutional right to privacy as occurred in Sivarasa should be considered. As the personal liberty clause encompasses a wide range of values connected with individual liberty, it is sensible to include the protection of the right to privacy under the umbrella of personal liberty. The route taken by the Indian courts could provide reference for Malaysia to develop the same. Besides, the judicial direction initiated in Lew Cher Phow, Lee Ewe Poh and Maslinda Ishak needs to continue if privacy is to be given the status of a right in Malaysia. Thus, a constitutional right to privacy and a common law tort have some potential to fill the gaps in the legal framework. Having discussed Sivarasa and common law principles, the thesis found that those two methods could provide protection to some aspects of privacy breach 
but not as comprehensive as what will be offered by the proposed Act itself. Thus, this thesis is advocating a more inclusive and direct approach, namely the enactment of a specific privacy action which is discussed in Chapter Seven. But, even if the courts prefer the common law path to the one being advocated in this thesis, they will need to look at other jurisdictions. Two of those are the UK and NZ, which are discussed in Part III.

Before those jurisdictions' experiences are examined, it is important to look at other Malaysian statutes' ability to afford protection to privacy interests which is discussed in the following chapter. 


\section{CHAPTER FOUR \\ A COMPARATIVE EXAMINATION OF STATUTORY PROTECTION OF PRIVACY IN MALAYSIA}

\section{Overview}

Apart from the constitutional protection and common law principles indirectly applicable for the protection of privacy and shown in the previous chapter to be inadequate, the next question to consider is how far the existing legislation provides protection against breach of privacy. It is important to explore such protection in criminal law and other statutes.

In addition to criminal law and other statutes, the only legislation in Malaysia that directly deals with an aspect of privacy interest, ie data privacy, is the Personal Data Protection Act 2010 (PDPA). As a result of rapid commercial and economic development and concerns about consumer needs, domestic or international trade, there is an urgent need for the introduction of data privacy legislation. Incidents involving violations of personal data, such as the credit status of individuals, has increased public awareness and the government's need to introduce a specific law to protect an individual's personal data. Issues such as rights and liabilities pertaining to information, protection of information from unlawful use, the right to information, the status of information belonging to individuals, and overall issues pertaining to the future of online trade and commerce using other people's data should be given attention in Malaysian legal development.

This chapter examines all legislative protections of privacy to determine their ability to provide sanctions and remedies for breach of privacy actions and also to underline their inadequacies. The main focus of such laws is the PDPA which is compared to two model countries' Acts: the UK Data Protection Act 
1998 (DPA) and the NZ Privacy Act 1993 (PA). This comparison is necessary to identify gaps the PDPA has in its current form and to suggest improvements based on the model countries' experiences.

Thus, Part I gives an overview of legislation that will be discussed in this chapter. Part II examines the criminal branch of law and other statutes that have an implication of privacy interests in Malaysia. Part III discusses the PDPA 2010 and its adequacy to protect private and personal information as defined by this thesis. Part IV analyses the UK Data Protection Act 1998 in order to address any gaps inherent in the PDPA. Part V analyses the New Zealand Privacy Act 1993 to understand the kind of data protection law which enhances the protection of personal data. Part VI analyses the flaws in the PDPA and addresses relevant provisions from the DPA and PA which would improve the Malaysian law. Part VII concludes the discussion and suggests ways to remedy the weaknesses in the PDPA.

\section{Relevant Statutes for the Protection of Privacy}

There is no specific legislation for the protection of privacy in the Malaysian legal framework. However, general protection for privacy may be sought from other legislation. The discussion in this Part evaluates protection provided by criminal law and other statutes.

\section{A Criminal law}

In the context of criminal law, the protection of privacy may be addressed by the protection from physical interference of a person's modesty or dignity. The word "privacy" in s 509 of the Penal Code is used in connection with words or gestures intended to insult the modesty of a person: 
Whoever, intending to insult the modesty of any person, utters any word, makes any sound or gesture, or exhibits any object, intending that such word or sound shall be heard, or that such gestures or object shall be seen by such person, or intrudes upon the privacy of such person, shall be punished with imprisonment for a term which may extend to five years, or with fine, or with both.

The phrase "intrudes upon the privacy of such person" implies wider protection for privacy interests. An offence is committed if there is an intrusion upon the privacy of another person with the intention of insulting that person's modesty. ${ }^{1}$ In other words, intrusion of privacy alone under s 509 does not amount to an offence. However, through case law, the provision has been construed to include the physical act of intruding on a person's privacy that does not involve any direct contact between the offender and the victim.

For example in Abu Hassan Bin Abd Jamal v Public Prosecutor, ${ }^{2}$ the court held that the appellant had committed an offence under s 509 of the Penal Code by exposing his private parts because such an act would naturally cause embarrassment and insult any person's modesty. The incident occurred in the canteen of a girls' primary school and was seen by a group of schoolchildren. The court determined that an offence under s 509 of the Penal Code is not a trivial offence and the circumstances under which the appellant committed it did not at all warrant the exercise of any discretion under s 173A of the Criminal Procedure Code to discharge the appellant conditionally or unconditionally. Thus, the fine and term of imprisonment imposed by the Magistrate was upheld.

\footnotetext{
${ }^{1}$ See Kong Lai Soo v Ho Kean [1973] 2 MLJ 250. In that case, the defendant's son was charged and convicted under s 509 of the Penal Code for exposing his private parts with the intention that the landlord's daughter could see them. The court held that it undoubtedly outraged the modesty of the landlord's daughter. ${ }^{2}$ [1994] MLJU 223 (HC).
} 
The case illustrates that s 509 protects some aspects of physical privacy and against some intrusions into modesty but does not fit within the definition of unwanted access to information or physical space or body given in Chapter Two.

Similarly, in Maslinda Ishak v Mohd Tahir Osman \& Ors ${ }^{3}$ the court held that taking numerous photos of the person in a squatting position urinating in public view was an offence under s 509. The defendant pleaded guilty and was convicted. ${ }^{4}$ The defendant's act was an intrusion into a person's modesty that is the primary focus of s 509. Both cases show that s 509 indirectly protects an individual's privacy in the situation where the act of intrusion occurs with the intention of offending that person's modesty.

To invoke s 509 in the context of unwanted physical access as defined in this thesis is inappropriate because sometimes unwanted or undesirable physical access occurs but has nothing to do with the other person's modesty. For example, Gavison's definition of solitude maintains that physical proximity is also a kind of physical access but there are certain occasions when physical proximity will not necessarily insult the person's modesty as provided by $\mathrm{s}$ 509. For example if a person is continually followed, watched or overheard, unwanted physical access occurs but these acts do not necessary insult a person's modesty. These kinds of unwanted access are not sanctioned by criminal law.

Another form of unlawful intrusion, such as assault and battery is provided for in the Penal Code. ${ }^{5}$ These provisions protect against bodily intrusion from any gesture or any preparation that will cause any person present to apprehend that criminal force is about to be applied to that person. Thus, the provision

\footnotetext{
${ }^{3}$ Maslinda Ishak, above ch 3, n 14.

${ }^{4}$ The defendant was convicted under s 509 of the Penal Code under Arrest Case C83-494 of 2003.

${ }^{5}$ Sections 350, 351 of the Penal Code (Act 574).
} 
prevents access to an individual's physical body. However, if A hits B's head, unwanted intrusion to B's physical body occurs but this in itself has nothing to do with privacy, and therefore, A is guilty of assault and battery under criminal law.

In terms of telecommunication privacy, s 234 of the Communications and Multimedia Act 1998 provides another potential avenue by which a person can be charged for intruding on the privacy of another in the context of data privacy. The provision prohibits unlawful interception of communications and unlawful disclosure of authorised interception. ${ }^{6}$ This clear prohibition of unlawful intentional interception and disclosure of communication is aimed at protecting the confidentiality of information. This provision is capable of covering interception of various forms of Internet communication including email, e-commerce transactions and chat-room interactions. The provision not only makes interception an offence, but also the disclosure and use of communications obtained through unlawful interception. ${ }^{7}$

In a situation where no criminal intimidation or threat exists, an offence under s 292 of the Penal Code occurs if the accused intrudes upon the privacy of others by possessing, circulating, distributing obscene acts or photos. ${ }^{8}$ This provision offers indirect protection of privacy to an individual if any acts or photos have been distributed, processed or circulated. ${ }^{9}$

\footnotetext{
${ }^{6}$ Section 234 provides on the prohibition of interception and disclosure of communications.

${ }^{7}$ Exceptionally, provisions in the Communications and Multimedia Act 1998 restricting telecommunications interception can be ignored or overridden by the Internal Security Act 1960 and the Computer Crime Act 1997. The Internal Security Act 1960 gives special powers to police to act in situations relating to subversive publication, internal security and for the preservation of public security. Further s 6 of the Computer Crimes Act 1997 provides that a person shall be guilty of an offence if he communicates directly or indirectly a number, code, password or other means of access to a computer to any person other than a person to whom he is duly authorised to communicate.

${ }^{8}$ Section 292 provides on Sale, etc., of obscene books, etc.

${ }^{9}$ The distribution of the copies of the DVDs of an MCA high council member having sex with an unknown woman was an offence under this provision. See above Chapter One, Part II.
} 
Other than that, there are specific measures to be observed by the police who conduct a search and seizure under the Criminal Procedure Code. ${ }^{10}$ The Code provides that the police officer or private person making the arrest may search a person and place in safe custody all articles other than essential clothing found upon him, and any of articles which there is reason to believe were the instruments or fruits or other evidence of the crime, and these may be detained until the discharge or acquittal of the person arrested. This procedure indirectly protects individual's privacy.

Looking at the nature of the offences and the extent of the protection offered by criminal law, it is clear that current law does not protect privacy adequately and a better legislative framework is desirable to provide a more encompassing safeguard for privacy interests. As discussed earlier in Chapter Three Part III (A), privacy is a branch of tort law. Therefore, to remedy a breach of privacy through a criminal law protection requires the proof of actus reus and mens rea, which are irrelevant in tort. Furthermore, criminal liability relies on police investigation and no compensation is available to the victim. In fact, even in circumstances where the breach is an offence against the state, invasion of privacy is a civil wrong against another person. Thus, criminal law protects privacy indirectly as long as it relates to the protection of modesty and human dignity but the protection does not extend to unwanted access over personal information and private space.

To conclude, it is possible for criminal sanction and civil liability for breach of privacy to co-exist. To illustrate the point, if A publishes an intimate photo of X, the offence is caught under s 292 of the Penal Code. ${ }^{11}$ A claim for compensation can be brought by $\mathrm{X}$, who wishes to keep the matter private, against A for unauthorised publication of personal information. Apart from

\footnotetext{
${ }^{10}$ Section 20 of the Criminal Procedure Code (Act 593).

${ }^{11} C v$ Holland [2012] 3 NZLR 672 is a New Zealand example of a situation where intimate filming resulted in both criminal sanction and civil liability.
} 
the criminal law, the following section examines possible protections for privacy in other statutes.

\section{B Other Statutory Protection}

As previously discussed, criminal laws are not capable of providing protection against breach of privacy. The question arises as to whether other laws may remedy the deficiencies in common law principles, the Constitution and the criminal law. This section examines the laws in order to answer such a question. $^{12}$

The Child Act 2001 protects the privacy of children under 18 years of age through restrictions imposed on the media for reporting and publicising any information relating to children. It prohibits the media from revealing the name, address, educational institution, or any particulars that may lead to the identification of any child. The prohibition also covers the publication of the photo of any child in a newspaper, magazine or electronic medium. ${ }^{13}$ However, the above restrictions do not apply if the Court for Children is satisfied that such revelation is necessary in the interest of justice and if there is an application by or with the authority of a Protector. ${ }^{14}$ Essentially, the protection provided is relevant only in cases of media intrusion and not the disclosure or publication of information by another individual. Though the law applies to a specific target, ie media, it undoubtedly acknowledges the importance of privacy of young people in Malaysia.

\footnotetext{
${ }^{12}$ See also discussions of privacy interest and legislation in Haidar, above ch 3 , n 67, at 209215.

${ }^{13}$ Section 15 provides restrictions on media reporting and publication. See also Haidar, above ch 3 n 67, at 210-211. The author explains how freedom of expression needs to be balanced with the interests of children.

${ }^{14}$ Section 15(3). "Protector" is defined in s 2 means- (a) the Director General; (b) the Deputy Director General;(c) a Divisional Director of Social Welfare, Department of Social Welfare; (d) the State Director of Social Welfare of each of the States; (e) any Social Welfare Officer appointed under s 8 .
} 
Indirect protection of personal privacy in terms of proprietary right is provided under s 44 (1) (a) of the National Land Code 1965:

Subject to the provisions of this Act and of any other written law for the time being in force, any person or body to whom (under this Act or a previous land law) land has been alienated, reserved land has been leased or temporary occupation license (including a license so styled under a previous land law) has been granted in respect of any land, shall be entitled to:

(a) the exclusive use and enjoyment of so much of the column of airspace above the surface of the land, and so much of the land below that surface, as is reasonably necessary to the lawful use and enjoyment of the land;

The above provides that a person has exclusive use and enjoyment of his land so far as it is reasonable to enjoy the proprietary rights. However, the phrase "reasonably necessary" implies that although the landowner has absolute control over the land and can exclude any unwanted or unnecessary access to it, the claim must be a reasonable one. ${ }^{15}$

Several statutory provisions explicitly include privacy as an element in protecting other interests. One relevant provision dealing indirectly with privacy is s 29b (4) of the Moneylenders Act 1951:

For the purpose of subsection (1), the doing of an act of harassment or intimidation upon another person includes the making of statements, sounds or gestures, or exhibiting of any object intending that such word or sound shall be heard or that such person shall see such gesture or object or intruding upon the privacy of such person.

\footnotetext{
${ }^{15}$ Refer Chen Yus Kiew (F) v Angkasamas Sdn Bhd [2003] 4 MLJ 365, K Mahunaran v Osmond Chiang Siang Kuan [1996] 5 MLJ 293. For detailed discussion of the cases, see Chapter Three, Part IV.
} 
The main interest in the protection scheme is to prohibit moneylenders from harassing and intimidating borrowers. The phrase "intruding upon the privacy of such person" suggests the effect of harassment on another person and not protection of privacy generally. Thus, in this provision, intrusion of privacy is an important element in order to establish the act of harassment or intimidation on the part of the moneylender. It does not aim to provide protection against an infringement of privacy.

Economic and technological advancement has an impact on privacy-related interests and accordingly Malaysia has enacted several cyber laws such as the Digital Signature Act $1997,{ }^{16}$ the Telemedicine Act $1997^{17}$ and the Personal Data Protection Act 2010. ${ }^{18}$ These laws are part of the legal infrastructure in regulating information and communication through cyberspace.

The protection of privacy in the cyber arena is the result of the government's commitment to develop the information technology sector in its goal to become a developed country by 2020 . This suggests that protection of privacy is necessary for economic purposes in information and communication technology rather than for the promotion of privacy as a foundational right in a democratic society. ${ }^{19}$

The above discussion reveals that no single piece of legislation addresses the general concept of privacy and its protection in Malaysia. A patchy form of

\footnotetext{
${ }^{16}$ The Digital Signature Act was enacted to instil confidence and encourage the public to perform secured electronic transactions domestically as well as internationally. Under the Act, the digital signature provides a verification system to authenticate the identity of the author and verify the transmitted message.

${ }^{17}$ The Act safeguards patient's privacy by providing that "The consent given by a patient under subsection (1) is not valid for the purpose of that subsection unless the fully registered medical practitioner has, before the consent is given, informed the patient - (c) that all existing confidentiality protection apply to any information about the patient obtained or disclosed in the course of the telemedicine interaction".

${ }^{18}$ The overview of the PDPA 2010, its applicability and the shortcomings will be discussed in the next part.

${ }^{19}$ Privacy is a matter of balance rather than human right. See Ida Madieha Azmi "ECommerce and Privacy Issues: An Analysis of the Personal Data Protection Bill" (2002) 16 IRLCT 326.
} 
protection in common law and legislation suggests that the existing framework provides protection for aspects of privacy but not for privacy generally. It mainly protects privacy indirectly because the nature of the privacy interest is embedded in the main action requiring protection by the relevant legislation. Some of these measures will protect privacy in limited and haphazard circumstances but by no means all.

The enactment of the PDPA can be an effective tool in providing protection of private information. Its details are discussed below.

\section{Personal Data Protection Act 2010}

This Part discusses briefly the reason for the introduction of the PDPA and examines in detail its scope and protection of personal data. It also analyses how far the Act provides protection against unwanted access to private information as defined in Chapter Two.

\section{A Introduction}

The draft Data Protection Bill in 1998 was the government's first effort to introduce a specific law on data protection. ${ }^{20}$ However, the first Bill never made it to the Parliament due to heavy opposition from the communication and multimedia industry. Later in 2001, it was redrafted for further relaxation of rules, and in 2009, it was tabled and debated in the March sitting of Parliament.

This Bill resulted in the introduction of the Personal Data Protection Act 2010 (the PDPA) which was passed in June $2010 .{ }^{21}$ It may be regarded as the single

\footnotetext{
${ }^{20}$ In 1998, the Malaysian government introduced a draft Data Protection Bill.

${ }^{21}$ The PDPA was passed on 5 April 2010 and was given the Royal Assent on 2 June 2010. It was gazetted and became law on 10 June 2010. See "Parliament: Personal Data Protection Bill Passed" The Star Online (Malaysia, 5 April 2010). It was in force on 15 November 2013.
} 
piece of legislation that specifically addresses the protection of personal data. Initially the PDPA replicated laws on personal data from other jurisdictions in respect of the personal data protection principles with modifications to suit local needs and circumstances. Its dominant influences are the Hong Kong Personal Data (Privacy) Ordinance 1995 and the UK Data Protection Act 1998. The personal data protection principles are identical to both pieces of legislation. The PDPA contains those principles in order to satisfy minimum requirements for the law governing the collection and processing of personal data. $^{22}$

According to Datuk Seri Dr Rais Yatim, ${ }^{23}$ the introduction of the PDPA will speed up the development of electronic connection and transactions such as ecommerce and e-business. It is expected that the law will, among other things, help Malaysia to become a communication and electronic trade centre, an attractive location for investment in multimedia and communications industries, and an international trade partner able to offer personal data protection assurance according to international standards. ${ }^{24}$ With the introduction of the Multimedia Super Corridor (MSC), this aim is in line with the government's desire to transform Malaysia into a knowledge-based economy and society and achieve a fully developed status by 2020 . This

\footnotetext{
${ }^{22}$ Article 25 of EU Directive provides that "(1) The Member States shall provide that the transfer to a third country of personal data which are undergoing processing or are intended for processing after transfer may take place only if, without prejudice to compliance with the national provisions adopted pursuant to the other provisions of this Directive, the third country in question ensures an adequate level of protection, (2) The adequacy of the level of protection afforded by a third country shall be assessed in the light of all the circumstances surrounding a data transfer operation or set of data transfer operations; particular consideration shall be given to the nature of the data, the purpose and duration of the proposed processing operation or operations, the country of origin and country of final destination, the rules of law, both general and sectoral, in force in the third country in question and the professional rules and security measures which are complied with in that country".

${ }^{23}$ The former Minister for Information, Communication and Culture (in office from 10 April 2009 - 5 May 2013).

${ }^{24}$ Rais Yatim "Protecting your personal data" The Star Online (Malaysia, 12 February 2012).
} 
initiative has been driven by Malaysia's fourth Prime Minister Tun Dr Mahathir Mohamed. ${ }^{25}$

The PDPA aims at regulating the collection, holding, processing and use of personal data in commercial transactions and also to prevent malicious use of personal information. It plays a crucial role in safeguarding the interest of individuals and makes it illegal for anyone, be it corporate entities or individuals, to sell personal information or allow such use of data by third parties. This objective is clearly outlined in its preamble: "to regulate and protect the process of personal data from being misused through commercial transactions and matters relating thereto."

For the first time in Malaysia the PDPA provides for the regulation and processing of both online and offline personal data in the area of commercial transactions for the purpose of providing protection for the interests of data subjects. ${ }^{26}$ The PDPA also has arguably filled the long-standing gap in relation to protecting an individual's private data. Previously, apart from certain sectoral secrecy obligations, information of a personal nature was protected only through contractual obligations or the common law. ${ }^{27}$ The PDPA is able to strengthen the management of personal data as a social obligation. The objective of protecting the privacy of an individual is important, quite apart from the objective of producing integrated and responsible daily practice of ecommerce use. $^{28}$

\footnotetext{
${ }^{25}$ The Multimedia Super Corridor (MSC) was introduced in 1996 which is intended to "leapfrog Malaysia into the Information Age." See <http://www.malaysia.gov.my.>

${ }^{26}$ See Zuryati Mohamed Yusoff "The Malaysian Personal Data Protection Act 2010: A Legislation Note" (2011) 9 NZJPIL 119. In this article, the author discussed the background of the Act, the scope, limitations of the Act and provided suggestions to remedy the flaws in the Act.

${ }^{27}$ Huriyyah El Islamy "Information Privacy in Malaysia: A Legal Perspective" (2005) 1 Malayan Law Journal xxv.

${ }^{28}$ See Rais, above $\mathrm{n} 24$.
} 
Before analysing the extent to which the personal data law provides protection for privacy interests, particularly private information, the following discussion assesses the PDPA's key features and its principles.

\section{$1 \quad$ Salient features}

The focus of the Act is the protection of personal data which is defined ${ }^{29}$ as

any information in respect of commercial transactions which-

(a) is being processed wholly or partly by means of equipment operating automatically in response to instructions given for that purpose;

(b) is recorded with the intention that it should wholly or partly be processed by means of such equipment; or

(c) is recorded as part of a relevant filing system, or with the intention that it should form part of a relevant filing system, that relates directly or indirectly to a data subject, who is identified or identifiable from that information or from that and other information in the possession of the data user, including any sensitive personal data and expression or opinion about the data subject; but does not include any information that is processed for the purpose of a credit reporting business carried on by a credit reporting agency under the Credit Reporting Agencies Act 2010.

Personal data, therefore, includes any information or opinion as far as it relates to an identified or identifiable living perso ${ }^{30}$ and is processed both

\footnotetext{
${ }^{29}$ Section 4.

${ }^{30}$ Section 4 defines data subject as an individual who is the subject of the personal data. The word individual here clearly points to living persons. The term "data user" refers to a person who either alone or jointly or in common with other persons processes any personal data or has control over or authorises the processing of any personal data, but does not include a data processor defined in s 4 . Data processor means any person, other than an employee of the data user, who processed the personal data solely on behalf of the data user, and does not process the personal data for any of his or her own purposes. According to Abu Bakar, a data user has to be a legal person and it covers individuals as well as companies and other corporate and unincorporated entities. See Abu Bakar Munir "Personal Data Protection Act: Doing Well By Doing Good" [2012] 1 MLJ lxxxiii.
} 
manually and electronically. ${ }^{31}$ However, personal data used for noncommercial purposes is not covered by s 4 . To invoke protection under the PDPA, data must relate to any transaction of a commercial nature, whether contractual or not, which includes any matters relating to the supply or exchange of goods or services, agency, investments, financing, banking and insurance, but does not include a credit reporting business carried out by a credit reporting agency under the Credit Reporting Agencies Act 2010.

According to Abu Bakar, the test to determine whether data is "personal data" is: can an individual be indentified from the data, or from the data which is in possession of the data user? If the answer is "yes", it is likely that the data is personal data. ${ }^{32}$

The processing of personal data is comprehensively defined in the PDPA to include all activities of a data user. It defines "processing" 33 to mean: collecting, recording, holding or storing the personal data or carrying out any operation or set of operations on the personal data including-

(a) the organisation, adaptation or alteration of personal data;

(b) the retrieval, consultation or use of personal data;

(c) the disclosure of personal data by transmission, transfer, dissemination or otherwise making available; or

(d) the alignment, combination, correction, erasure or destruction of personal data.

\footnotetext{
${ }^{31}$ Section 4 defines "relevant filing system" to mean any set of information relating to individuals to the extent that, although the information is not processed by means of equipment operating automatically in response to instructions given for that purpose, the set of information is structured, either by reference to individuals or by reference to criteria relating to individuals, in such a way that specific information relating to a particular individual is readily accessible.

${ }^{32}$ Abu Bakar, above n 30, at 1xxxiv. The author gives an example of a name such a Muhammad or John which would not be regarded as personal data on its own, but other personal information combined with the name such as addresses or an identification number, the combined information is personal data because a person can be clearly identified by such information.

${ }^{33}$ Section 4.
} 
The PDPA provides a regulatory framework for the processing of personal data in commercial ${ }^{34}$ transactions. Thus, the meaning of "commercial transactions" is crucial in order to understand the nature of the personal data protected under the PDPA. Commercial transactions refer to ${ }^{35}$

any transaction of a commercial nature, whether contractual or not, which includes any matters relating to the supply or exchange of goods or services, agency, investments financing, banking and insurance, but does not include a credit reporting business carried out by a credit reporting agency under the Credit Reporting Agency Act 2010.

From the definition, the data and confidential information of online consumers fall under the meaning of "commercial transactions". Thus, if a customer gives the name, address, contact number and other information to complete a transaction, that data or personal information is protected under the PDPA. The company receiving the information is under an obligation to keep the data and is only allowed to use or disseminate it with the consent of the data subject. Conversely, the data of a patient in relation to medical treatment does not fall under this definition as it does not have commercial features. Nevertheless, that data merits similar protection for the reason that it is easily abused and misused through online transactions. ${ }^{36}$ Similarly, the PDPA has no application to personal data collected through social media networking websites such as Facebook, Twitter and MySpace because that data is not a result of commercial transactions. ${ }^{37}$ The fact that this data is stored and held

\footnotetext{
${ }^{34}$ The word "commercial" has not been defined in Malaysian commercial legislation - the Contracts Act 1950, the Sale of Goods Act 1957, Banking and Financial Institutions Act 1989, the Consumer Protection Act 1999 and also the Hire Purchase Act 1967.

${ }^{35}$ Section 4 . The definition of personal data also excludes the information processed for the purpose of credit reporting business and is redundant with the definition of "commercial transaction".

${ }^{36}$ However, there is a partial exemption for personal data processed in relation to information of the physical or mental health. That data shall be exempted from the Access Principle and other related provisions of the PDPA. This exemption is provided in s 45(2)(b).

${ }^{37}$ See also Foong Cheng Leong "Personal data and the law" The Star Online (Malaysia, 5 August 2010).
} 
by foreign online providers which do not have local centres of dataprocessing, justifies its exclusion from the scope the Act. ${ }^{38}$

In relation to the definition of "commercial transactions", it is interesting to note the definition of "credit reporting agency" as the PDPA expressly excludes its application to such business. Under the Credit Reporting Agencies Act 2010 (CRA 2010) ${ }^{39}$ the consent $^{40}$ of an individual is needed before financial information can be revealed by credit-reporting agencies. ${ }^{41}$ In its explanatory statement, the CRA states that the purpose of the legislation is "to provide for the registration and regulation of persons carrying on credit reporting businesses and for matters connected therewith and incidental thereto". The term "credit reporting business" as provided under the CRA 2010 means: ${ }^{42}$

a business that involves the processing of credit information for the purpose of providing a credit report to another person, whether for profit, reward or otherwise, but shall not include the processing of credit information-

(a) for the purpose of discharging regulatory functions or that is required or authorized by or under any law; or

(b) by a credit rating agency.

Thus, all businesses which fall under this definition will be governed by the CRA 2010 and not by the PDPA. This specific exclusion of credit reporters from the ambit of the Act is harmful for data users whose information is

\footnotetext{
${ }^{38}$ This is expressly provided under section 3(2) that "This Act shall not apply to any personal data processed outside Malaysia unless that personal data is intended to be further processed in Malaysia".

${ }^{39}$ The Act adopted the New Zealand Credit Reporting Privacy Code 2004 which is established under the Privacy Act 1993.

${ }^{40}$ Section 24(1)(a) of the CRA 2010 provides that "No credit reporting agency shall disclose any credit information for any purpose to any person unless the customer has given his consent to the disclosure".

${ }^{41}$ See Zulkifli Abd Rahman "Bill requiring credit-reporting agencies to obtain consent passed" The Star Online (Malaysia, 20 April 2010).

${ }^{42}$ Section 2 of the CRA 2010.
} 
collected by them and sold to other parties. However, the Deputy Finance Minister Datuk Dr Awang Adek Hussin has stated that the activities of creditreporting agencies will also be checked through other provisions under the Companies Act and the PDPA. The onus is on the credit-reporting agencies to prove that they have taken reasonable steps to hold correct and up-to-date information in their database. This is to prevent problems of incorrect financial information of consumers by unverified sources. ${ }^{43}$ In this sense, a consumer's data is protected from being intruded upon or altered because the consumer has the right to inspect and give consent as to whether the data is to be displayed or not.

\section{$2 \quad$ Personal data protection principles}

The core of the PDPA is the personal data protection principles. The Act requires that a data user complies with all the principles in processing personal data outlined in Part II of the Act. ${ }^{44}$ These principles are framed by reference to international instruments governing the protection of privacy and trans-border flows of personal data. The interrelationship of computers, freedom, privacy and trade has become a topic of concern among international organisations. ${ }^{45}$ The seven principles are briefly discussed here. ${ }^{46}$

The PDPA does not allow a data user to process any personal data about an individual unless that individual has given consent to the processing of the

\footnotetext{
${ }^{43}$ Zulkifli, above n 41.

${ }^{44}$ Section 5.

${ }^{45}$ Rosemary Jay Data Protection Law and Practice ( ${ }^{\text {rd }}$ ed, Sweet \& Maxwell, London, 2007) at 6 [Data Protection Law and Practice].

${ }^{46}$ Various authors have addressed the personal data protection principles under the PDP 2010. Among them are Khaw Lake Tee "Towards a personal data protection regime in Malaysia" (2002) JMCL 11; Abu Bakar Munir "Data Protection Law: Too little, too late?" (Public Lecture 2009, Universiti Malaya, 4 August 2009); Ida Madieha Azmi "E-Commerce and privacy issues: An analysis of the Personal Data Protection Bill" (17 $7^{\text {th }}$ BILETA Annual Conference, Free University, Amsterdam, 5-6 April 2002) and Graham Greenleaf "Limitations of Malaysia's data protection Bill" (2010) 104 Privacy Laws and Business International Newsletter 1.
} 
personal data. ${ }^{47} \mathrm{~A}$ data user shall not process any sensitive personal data about a data subject unless consent is given and the processing is in accordance with the provision of s $40 .^{48}$ The personal data shall not, without the consent of the data subject, be disclosed except where the disclosure is in connection with what it was collected for or is directly related to the data user's activity. ${ }^{49}$

Consent is vital in the processing of personal data. However, the PDPA does not define consent. According to Abu Bakar, consent in the PDPA can mean any freely given specific and informed indication of a data subject's wishes and his agreement to his personal data being processed and whether oral or implied. $^{50}$

Section 7 states that where a data user is required to give written notice informing an individual ("the data subject") that his personal data is being processed by, or on behalf of the data user, the notice shall, amongst other things, include the purpose for which the personal data is being collected, and whether it is obligatory or voluntary for the data subject to provide his personal data. The notice must be given at the earliest opportunity for the data subject to supply his personal data.

In the absence of consent by the data subject, the Act prohibits the data user from disclosing the personal data. ${ }^{51}$ The data user may only disclose the personal data for the purpose or directly related purpose, which the data was disclosed at the time of collection. Also, the data user can only disclose the personal data to a third party or a class of third parties, whose existence is made aware to the data subject, and the data subject's consent obtained before the personal data is processed by the third parties. However, s 39 provides for

\footnotetext{
${ }^{47}$ Section 6 - General Principle.

${ }^{48}$ Section 40 - Processing of sensitive personal data.

${ }^{49}$ Section 6(2)(a)-(f) and 6(3)(a)-(c).

${ }^{50} \mathrm{Abu}$ Bakar, above n 30 at lxxxvii. See also art 2(h) of the Directive 95/46.

${ }^{51}$ Section 8 - Disclosure Principle.
} 
circumstances in which personal data may be disclosed, ${ }^{52}$ notwithstanding that such disclosure may contravene s 8 .

The law requires the data user to protect and safeguard the personal data of the data subject by taking practical steps to implement appropriate security measures. ${ }^{53}$ It is the duty of the data user to take all necessary steps to protect any loss, misuse, modification, unauthorised and accidental access or disclosure, alteration or destruction of personal data. The data user must take steps that are commensurate with the risk of processing the data while having regard to the cost of its implementation. There is, therefore, a balancing act between the seriousness of the consequences of a failure to secure the personal data and the costs implications involved in protecting the data. ${ }^{54}$

Section 10 provides that the personal data processed cannot be kept longer than is necessary, and the data user shall take all reasonable steps to destroy personal data no longer required. However, this provision does not specifically mention the lifespan of personal data. Once the data is no longer required for the purpose for which it was processed, it must be destroyed or permanently deleted.

Section 11 states that a data user must ensure that personal data is accurate, complete, not misleading, kept up to date, and related to the purpose. It is the duty of the data user to guarantee the accuracy, completeness and correctness of the data collected. The data user must also maintain that the data is current for its purpose, including any directly related purpose, for which the personal data was collected and further processed. It is essential to preserve the

\footnotetext{
${ }^{52}$ Under s 39, disclosure is permitted if it is necessary for the purpose of preventing or detecting a crime, or for the purpose of investigations or required under any law or order of a court or the disclosure justified public interest.

${ }^{53}$ Section 9 - Security Principle.

${ }^{54}$ See also Abu Bakar, above n 30 at lxxxix.
} 
integrity of a data because inaccurate and incomplete data may have a direct or indirect effect on data subjects. ${ }^{55}$

A data subject must be given access ${ }^{56}$ to the personal data held by the data user and be able to correct, amend or delete personal data whenever it is inaccurate, misleading or not up-to-date. However, access or correction may be refused under the Act. ${ }^{57}$

In any processing and handling of personal data, it is mandatory for the data user to observe all data protection principles and any contravention of the principles results in an offence committed by the data user. ${ }^{58}$

\section{$3 \quad$ Rights of data subject}

In terms of security for the data subjects, the Act offers various rights to individuals to safeguard their personal data. The rights guaranteed include the right of access to personal data, ${ }^{59}$ the right to correct personal data, ${ }^{60}$ the right to withdraw consent, ${ }^{61}$ and the right to prevent the collection, holding, processing or use of any personal data which is likely to cause damage or distress ${ }^{62}$ and the right to prevent processing for the purposes of direct marketing. ${ }^{63}$

\footnotetext{
${ }^{55} \mathrm{At} \mathrm{xc}$.

${ }^{56}$ Section 12.

${ }^{57}$ Sections 32 and 36 provides circumstances where data user may refuse to comply with data access request and data correction request respectively.

${ }^{58}$ Section $5(2)$ provides that on conviction, a data user shall be liable to a fine not exceeding RM300,000 or to imprisonment for a term not exceeding two years or to both. In contrast, there are no criminal penalties in the Data Protection Act 1998.

${ }^{59}$ Sections $30-33$.

${ }^{60}$ Sections 34-37.

${ }^{61}$ Sections 38-41.

${ }^{62}$ Section 42.

${ }^{63}$ Section 43.
} 
A data subject is entitled to be informed by a data user whether the personal data is being processed by or on behalf of the data user. ${ }^{64}$ Data subjects are also given the right to correct personal information where they find the data inaccurate, incomplete, misleading or out-of-date. In respect of these rights, a data subject may withdraw consent by giving notice in writing to the effect of such withdrawal. These provisions give data subjects a wider right to control, allow and deal with the processing of their personal data. Failure to comply with the provisions of the Act is covered by a number of new criminal offences. ${ }^{65}$ However, there is no provision providing for a redress that could be claimed by data subjects in cases of processing of personal data not in accordance with the PDPA.

\section{B Enforcement}

In terms of enforcement, the PDPA provides for a Personal Data Protection Commissioner who is appointed by the Minister. The Commissioner has various functions ${ }^{66}$ and powers ${ }^{67}$ particularly in implementing and enforcing the law. The Commissioner is responsible for advising the Minister on the national policy for personal data protection and for implementing all relevant actions in exercising the administration of personal data as spelt out by the Act and directed by the Minister. However, despite the wide functions and powers granted to the Commissioner under the Act, the Commissioner is responsible and answerable to the Minister. ${ }^{68}$

\footnotetext{
${ }^{64}$ Section 30(1).

${ }^{65}$ In relation to the offences, a few of them are mentioned here. Section 132 provides that the prosecution can only be instituted by, or with the written consent of the public prosecutor. Section 135 provides that a Sessions Court shall have the jurisdiction to try any offence under the PDPA and to impose full punishment for any such offence under the Act. Section 5(2) makes it an offence for failure to comply with the personal data protection principles.

${ }^{66}$ Section 48. Among the functions are to advise the Minister on the national policy for personal data protection and related matters, to implement and enforce the personal data protection laws and to supervise compliance with the provisions of the Act.

${ }^{67}$ Section 49 . The Commissioner has all powers to do things necessary in connection with the performance of his functions under the Act.

${ }^{68}$ Section 59. Greenleaf in "Limitations of Malaysia's data protection Bill", above n 43 pointed out that this provision further underlines the Commissioner's lack of independence.
} 
The Commissioner has an administrative duty to decide whether a serious breach of personal data protection principles has occurred through a complaint by any person regarding an act or practice that contravenes the provision of the Act. ${ }^{69}$ Upon receiving a complaint, an investigation is carried out in accordance to s 105 . The Commissioner may refuse an investigation if that there has been no contravention of the Act. On completion of the investigation, if the Commissioner is satisfied that contravention of the Act has occurred, an enforcement notice as provided under s 108 is issued.

The Commissioner may later appoint an authorised officer to exercise the powers of enforcement under the Act. The decision specified in the enforcement notice may be challenged by filing a notice of appeal with the Appeal Tribunal. A decision of the Commissioner is not final. An aggrieved party may appeal to the Appeal Tribunal ${ }^{70}$ whose decision is final. ${ }^{71}$

\section{Limitations}

The PDPA passed with a few limitations. ${ }^{72}$ Section 2 provides that the Act applies only to a person who processes or who has control over or authorises the processing of personal data in respect of commercial transactions. This

The position is different with the Privacy Commissioner under the NZ Privacy Act 1993 (s 12) who is an Independent Crown Entity. It is funded by the State, but is independent of government or ministerial control. Section 7 of the Crown Entities Act 2004 categorises Privacy Commissioner as one of the Independent Crown Entities which are generally independent of government policy. See also Part 3 of Schedule 1 of the Crown Entities Act 2004.

${ }^{69}$ Section 104.

${ }^{70}$ Section 93. The Appeal Tribunal shall consists of a Chairman and at least two other members of the Judicial and Legal Service of the Federation appointed by the Minister as stated under section 85 of the Act.

${ }^{71}$ Section 99 provides that the decision of the Appeal Tribunal on any matter shall be decided on a majority of members of the Appeal Tribunal and the decision is final. Section 100 provides that a decision given by the Appeal Tribunal may, by leave of the Sessions Court, be enforced in the same manner as a judgment or order to the same effect, and where leave is so given, judgment may be entered in terms of the decision.

${ }^{72}$ Discussions on limitations of the PDPA either when it was a Bill or after it becomes a law can also be found in Khaw Lake Tee "Towards a personal data protection regime in Malaysia" and Greenleaf "Limitations of Malaysia's data protection Bill", above n 45; See also Zuryati, above n 26. 
precludes the application of the Act to non-commercial affairs even though the information communicated in such transactions has equal need of protection. Thus, if a person's personal data such as intimate photos, marital status, identity number, mobile number, and home address are disclosed, distributed and transferred for non-commercial, the PDPA fails to assist. Moreover, a clear exclusion of a credit reporting business as provided under the CRA 2010 does not help people whose banking information has been processed by credit reporting agencies.

The Act does not bind the Federal Government and State Governments. ${ }^{73}$ As far as data and personal information are concerned, governments are the biggest collectors and holders of such data. Thus, the law must bind them if it is to prevent abuse and mishandling of personal data and protect information privacy. The non-application of the Act to public sectors has in fact made it less significant as excludes parties that deal with most personal data. There is no principled reason for its exclusion but, according to Datuk Seri Dr Rais Yatim, the Federal and State Governments are exempted from the PDPA application because the exemption provides space and the right for the government's use of an individual's basic personal data to be processed for legal administrative purposes. ${ }^{74}$ This significant exemption is problematic and highlights the need for application of the Privacy Bill to everybody including public authorities.

Article 28 of the EU Directive provides that there must be an independent supervisory authority to enforce the law. Under the PDPA, a Personal Data Protection Commissioner appointed by the Minister ${ }^{75}$ has a range of powers. ${ }^{76}$ Section 47(3) provides that the Commissioner is a body corporate having perpetual succession and a common seal. Obviously, therefore, the

\footnotetext{
${ }^{73}$ Section 3.

${ }^{74}$ See Rais, above n 23.

${ }^{75}$ Section 47.

${ }^{76}$ Sections 48 and 49.
} 
Commissioner is not a natural person but an entity created by the law. The Minister may revoke the appointment, ${ }^{77}$ or the Commissioner may resign office by giving written notice to the Minister. ${ }^{78}$ The position of the Commissioner as provided by the Act is incompatible with a body corporate entity which has perpetual succession. The Commissioner is responsible to the Minister $^{79}$ and the Minister may give the Commissioner directions of a general character consistent with the provisions of the Act, thus signifying that the position of the Commissioner under the PDPA is not independent and fails to satisfy the EU adequacy requirement test. In Malaysia this may affect the transfer of personal data though it may still take place provided that the originating party takes additional measures to ensure that data is adequately protected..$^{80}$

The Commissioner should be answerable directly to Parliament in order to gain more independence in exercising his function under the Act. However, this argument is refuted on the basis that such position is a distortion of the established doctrine of separation of powers adopted by the Malaysian Constitution. $^{81}$

What is lacking in terms of enforcement of the PDPA is that although it has created a number of criminal offences for failure to comply with the provisions of the Act, it does not gives the data subject the right to enforce protected rights directly in the court. Under the DPA, however, certain rights

\footnotetext{
${ }^{77}$ Section 54(1)

${ }^{78}$ Section $54(2)$

${ }^{79}$ Section 59.

${ }^{80} \mathrm{Abu}$ Bakar Munir "Malaysian Data Protection Law is Inadequate" (2010) <http://profabm.blogspot.com.>.

${ }^{81}$ In the Malaysian context, the governing bodies are the Executive, the Legislative and the Judiciary. Each body has specific powers: to enforce the law, make the law and interpret and apply the law. Specific provisions for each of them are outlined in the Constitution, arts 73-79 (Legislative powers), arts 39-40 (the Executive) and art 121 (the Judiciary).
} 
of the data subject may be enforced directly in the court. ${ }^{82}$ An Amendment to the PDPA should include provisions for redress and compensation so that in case of breach of privacy, adequate protection is available.

Under s 45(1), the personal data protection principles have no effect on personal data processed by an individual for personal, family, household affairs and recreational purposes such as photographs of family members for personal keeping, or information about household collections. ${ }^{83}$ This broad exemption is in line with the main intention of the PDPA to protect personal data in commercial transactions only. Similarly, the processing of personal data for journalistic, literary and artistic purposes is exempt from the principles if the publication is of interest to the public. ${ }^{84}$

Having discussed the scope and application of the PDPA and identified its flaws, the following section examines the UK Data Protection Act 1998 in order to further improve the PDPA.

\section{Data Protection Act 1998}

As discussed above, one of the main influences on the PDPA was the DPA. However, in many respects, the UK legislation is more comprehensive and effective. This Part analyses relevant protection for privacy interests offered by the DPA. It evaluates the ability of the DPA to protect private information and how the DPA could address gaps in the PDPA.

\footnotetext{
${ }^{82}$ Sections 15 of DPA 1998 provides that "The jurisdiction conferred by sections 7 to 14 is exercisable by the High Court or a county court or, in Scotland, by the Court of Session or the Sheriff."

${ }^{83}$ This exemption is also known as total exemption.

${ }^{84}$ Section $45(2)(f)$. This exemption is known as partial exemption because it is exempted from certain principles only.
} 
The Data Protection Act 1984 was introduced to provide legal protection to an aspect of privacy, namely informational privacy. It ensures that personal information is collected, used and stored in an acceptable and suitable way: "An Act to regulate the use of automatically processed information relating to individuals and the provision of services in respect of such information".

In 1998 the 1984 Act was repealed and the Data Protection Act 1998 (the DPA) was introduced to extend and update the older Act to bring it into line with the European Directive ${ }^{85}$ and to harmonise data protection in the European Union. The DPA's long title clarifies its aim to provide for the regulation of the processing of information relating to individuals, including the obtaining, holding, use or disclosure of such information. The central focus is that data held on individuals must be fairly collected and used. This emphasis promotes the handling of personal data and prevents its processing in an unfair, damaging and intrusive way. The DPA is not intended to be privacy legislation; its aim rather is the better regulation of personal data transfer: ${ }^{86}$

(i) the processing of information of an individual to be executed according to the rules and practices;

(ii) to grant specific rights to an individual in respect of the information; and

(iii) to ensure that rules, rights and practices are carried out by an independent supervisory body.

\footnotetext{
${ }^{85}$ The European Directive requires member states to protect the fundamental rights and freedom of natural persons, in particular their right to privacy with respect to the processing of personal data stated under Art 1 of the Directive 95/46/EC.

${ }^{86}$ Mark Warby, Nicole Moreham and Iain Christie Tugendhat and Christie The Law of Privacy and The Media ( $2^{\text {nd }}$ ed, Oxford University Press, Oxford, 2011) at 275-276 [The Law of Privacy and The Media].
} 


\section{B Key sections}

The term "personal data" as defined by the Act indicates clearly that the Act applies exclusively to records relating to people, not companies. So long as a record falls within the terms of the Act and can be used to identify the individual to whom it refers, including opinions and an indication of the intention of the data subject, it is subject to the DPA.$^{87}$ Eight data protection principles are recognised; most are from the 1984 Act with an additional principle which prohibits the transfer of data outside the European Economic Area unless the country to which it is to be transferred has an adequate level of data protection. ${ }^{88}$ The Data Protection Directive 98/46/EC was adopted in October 1995. A Directive in European law imposes a requirement on Member States to pass national law to implement it.

The DPA protects the wrongful processing of "personal data". "Personal data" in s 1 simply means "data which relate to a living individual who can be identified (a) either from this data, or (b) from data and other information which is in the possession of, or is likely to come into the possession of, the data controller". The photograph of an individual therefore, clearly falls within the definition of the Act. For example in Douglas $v$ Hello $^{89}$ the three defendants were clearly data controllers, and the publication of the material in the UK amounted to processing and, therefore, fell under the jurisdiction of the Act. The processing itself was both unfair and unlawful being without justification under Schedule 2 of the Act. Thus there was a breach of DPA. Lord Phillips MR said: ${ }^{90}$

Nor is it right to treat a photograph simply as a means of conveying factual information. A photograph can certainly capture every

\footnotetext{
${ }^{87}$ Section 1 on basic interpretative provisions.

${ }^{88}$ Article 25 of the EU Directive 1995 provides that no personal data may be transferred to a third country unless the "third coutry in question ensures an adequate level of protection." ${ }^{89}$ [2005] 3 WLR 881.

${ }^{90}$ At [106].
} 
detail of a momentary event in a way which words cannot, but a photograph can do more than that. A personal photograph can portray not necessarily accurately, the personality and the mood of the subject of the photograph.

The definition of 'data' in the 1998 Act $^{91}$ covers automatic and manual types of data. 'Data' means information which -

(a) is being processed by means of equipment operating automatically in response to instructions given for that purpose,

(b) is recorded with the intention that it should be processed by means of such equipment,

(c) is recorded as part of a relevant filing system or with the intention that it should form part of a relevant filing system,

(d) does not fall within paragraphs (a) (b) or (c) but forms part of an accessible record as defined in s 68, or

(e) is recorded information held by a public authority and does not fall within any of paragraphs (a) to (d).

Data held on individuals must be fairly collected and used. Thus, the Act is applicable to data that is held on any electronic storage system, typically a computer, or if it forms part of a filing system including manually kept paper records. ${ }^{92}$ It is wide enough to cover materials including photographs in a newspaper, broadcast on television or published on a website. The DPA covers all electronic or automatically processed records including obvious records such as e-mails and information stored in a database. It also encompasses voice-mail messages stored on a telephone system, entry pass records, word processing systems, files held on computer, CCTV records, and other similar records.

\footnotetext{
${ }^{91}$ In 1984 Act, data was defined as information recorded in a form in which it can be processed by equipment operating manually in response to instructions given for that purpose. ${ }^{92}$ Section 1.
} 
It also covers personal data held in manual (or hard copy) format, provided the data held manually is in a "relevant filing system." 93 This means that manual or paper records will be covered by the Act as personal data provided that such specific information relating to a particular individual is readily accessible.

The definition of "processing" is wide and includes obtaining, recording, or holding information or data or carrying out any operation or set of operations on them, including organisation, adaptation, alteration, retrieval, consultation, use, disclosure by transmission, dissemination or otherwise making available, alignment, combination, blocking, erasure or destruction. ${ }^{94}$ In short, "processing" appears to cover all activities related to the handling of information or data. Thus, if a reporter extracts information about a local artist from a database, and publishes it in the newspaper, the act is subject to data protection principles outlined in the DPA.

\section{Data protection principles and rights of data subjects}

There are eight data protection principles set out in the DPA. Data protection principle 1, states that in order for data processing to be lawful, such processing must meet one of the conditions set out in Schedule 2, or Schedule 3 if the data to be processed is sensitive. Legitimate processing as intended by the DPA, s 4(3) requires a data subject to give consent to the processing (Schedule 2; or express consent in the case of processing sensitive data as per Schedule 3). The data controller has a control mechanism to allow or not the

\footnotetext{
${ }^{93}$ Section 1 on "relevant filing system" means any set of information relating to individuals to the extent that, although the information is not processed by means of equipment operating automatically in response to instruction given for that purpose, the set is structured, either by reference to individuals or by reference to criteria relating to individuals, in such a way that specific information relating to a particular individual is readily accessible.

${ }^{94}$ Section 1 of the DPA. See also The Law of Privacy and The Media, above 86 at 283-284; Data Protection Law and Practice, above n 45, at 136-137
} 
processing of personal data thus protecting an individual's right to information.

Consent to processing is the key principle of the DPA. It is a pre-condition as well as a continuing condition for legitimate data processing. The data subject may refuse consent for data processing or at any time withdraw consent and that results in any processing or further processing of the data illegitimate. To ensure that this requirement is observed, the data controllers are responsible for obtaining consent from individuals to process their personal data and to process it fairly. ${ }^{95}$ Thus, the law protects individual privacy by requiring consent for the processing of personal data and that the processing of such data not be pursued further if consent is withdrawn.

Principle 2 requires that personal data shall be obtained for one or more specified and lawful purposes only and shall not be further processed in any manner incompatible with that purpose or those purposes. ${ }^{96}$ The principle also determines whether any disclosure of personal data is compatible with the purpose or purposes for which it was obtained. This principle also considers the purpose or purposes for which the personal data are intended to be processed by any person to whom it is disclosed. This limitation ensures that data processing is only permitted for specified purposes and the data subject has the right to prevent processing if such processing is meant for any purpose(s) incompatible with the specified purpose or purposes for which the data subject has given consent. If data processed is different from what was lawfully required for a particular purpose, the processing has breached the principle. ${ }^{97}$

\footnotetext{
${ }^{95}$ See Schedule 1 Part II, [1]-[2]. See also Data Protection Law and Practice, above n 44 at 149-150; The Law of Privacy and The Media, above 86 at 289-290.

${ }^{96}$ See The Law of Privacy and The Media, above 86, at 292. See also Schedule 1 Part II, [5].

${ }^{97}$ Schedule 1 Part II, [5].
} 
Principle 3 provides that personal data shall be adequate, relevant and not excessive in relation to the purpose or purposes for which it is processed. ${ }^{98}$ This principle is straight-forward and self-explanatory. Accuracy is an important characteristic of personal data protected by Principle 4 . The data controller must take reasonable steps to ensure accuracy in the light of the purposes for which the data was obtained and further processed. Principle 5 does not provide a life span for keeping personal data, but simply requires that it shall not be kept longer than necessary for the purposes for which it was processed.

Principle 6 which requires that personal data shall be processed in accordance with the rights of data subjects under the DPA. The rights of data subjects are set out in ss 7 and 10 to 12 of the DPA. All rights guaranteed therein may be interpreted so as to ensure individual's privacy to some extent. Section 7 provides for the data subject's right of access to personal data. By virtue of $\mathrm{s}$ 7, a data subject has the right to be informed by any data controller if his personal data is being processed by or on behalf of the latter. The information so provided shall include the description of the personal data of such data subject; the purpose of processing; and the recipients or classes of recipients to whom the data is or may be disclosed. Furthermore, the data subject is entitled to have the information constituting his personal data and the source of such data communicated in an intelligible form. In the case of automatic processing of personal data for the purpose of its evaluation, the data subject is entitled to be informed of the logic behind such a decision. ${ }^{99}$

Subject to the fulfilment of the conditions set out in $s 7$, this right of access allows an individual to be informed of the purpose of processing his data, its accuracy and the means by which the data has been made available to the data controller. Combined with other provisions of the DPA, the data subject is

\footnotetext{
${ }^{98}$ Schedule 1 Part I, [3].

${ }^{99}$ The Law of Privacy and The Media, above n 86 at 295.
} 
able to exercise control over personal data to permit or not the process to be affected to such data and to prevent or stop further processing as necessary. This may be achieved by withdrawing consent to such processing or by asserting that such processing is in contravention of any provision of the DPA. ${ }^{100}$ The power to control the processing of personal data by the data subject demonstrates an individual's right to privacy of personal data.

Section 10 empowers the data subject to prevent processing likely to cause damage or distress. In this regard, the data subject is able to permit or prevent the processing of personal data and protects an individual's privacy against the processing of distressing personal information. ${ }^{101}$ Section 11 allows a right to prevent processing for purposes of direct marketing. Further, subject to the fulfilment of the conditions, s 12 entitles a data subject to require a data controller to prohibit any decision that significantly affects the data subject solely based on processing by automatic means. ${ }^{102}$

Finally, principle 8 dictates that no data shall be transferred to a country or a territory outside the European Economic Area (EEA) unless such country or territory ensures an adequate level of protection for the rights and freedoms of data subjects in relation to the processing of personal data. ${ }^{103}$ This principle provides further assurances that any rights and protection to be afforded to the data subjects are not limited merely within the EEA, and that if any data is processed outside the EEA it is subject to the conditions of the eighth principle. $^{104}$

\footnotetext{
${ }^{100}$ At 295-296.

${ }^{101}$ See also David Bainbridge Data Protection Law ( $2^{\text {nd }}$ Ed, XPL Publishing, Great Britain, 2005) at 143-144 [Data Protection Law]; The Law of Privacy and The Media, above n 86 at 299-300.

${ }^{102}$ At $149-150$.

${ }^{103}$ Schedule 1, Part I, [13].

${ }^{104}$ The Law of Privacy and The Media, above 86 at 301.
} 


\section{Exemptions}

Apart from protections and rights afforded to the data subject, the DPA also lists the exemptions that apply to particular data or processing. Sections 28 to 39 of the DPA outline the exemptions that exclude the particular data or processing from the enforcement power of the Information Commissioner. The effect of the exemptions leaves an individual with no redress under the DPA 1998 even if the data is inaccurate or the processing causes loss or damage. However, remedies may be sought through other laws, including that of Art 8 of the ECHR applicable by virtue of the Human Rights Act 1998.

The exemption under s 32 applies to the processing for the purpose of journalism, literature and artistic work. If publication of personal data is in the interest of the public in terms of freedom of expression or incompatible with special purposes, it is exempted from any provision of the DPA. ${ }^{105}$ Such exemption occurred in Campbell v MGN Ltd. ${ }^{106}$ Campbell brought an action against the Mirror for compensation under s 13 of the DPA. The Mirror relied on s 32 that allows exemption from a large number of provisions in the Act including the right to compensation. As the processing of the data in Campbell fell within the Act, the exemption applied to it, thus the Mirror was entitled to invoke the protection of the s 32 exemption in answer to Campbell's claim. In that case, the data controller held that publication was in the public interest, thus the exemption from s 32 was of wide application to the press and other daily media. ${ }^{107}$

The House of Lords in Campbell held that the publication of three disputed items of information: (1) the fact that she was receiving treatment at Narcotics Anonymous, (2) details of the treatment including how often and what kind of

\footnotetext{
${ }^{105}$ Section 32(1) (a)-(c).

${ }^{106}$ [2004] UKHL 22 (Campbell). Section 32 exempts personal data which are processed for any journalistic, literary or artistic purposes from provisions of the Act.

${ }^{107}$ The effect of s 32 in Campbell was discussed in Data Protection Law, above n 101, at 182-

183. See also The Law of Privacy and The Media, above 86 at 309-310.
} 
treatment etc, and (3) the photograph of her leaving the meeting place, amounted to a misuse of Campbell's private information. Although there was no finding on a cause of action in DPA, the court accepted that the dispute fell within the action of misuse of private information and awarded Campbell monetary compensation under s 13 of the Act. ${ }^{108}$

Section 36 provides that personal data relating to an individual's personal, family or household affairs including recreational purposes are exempt from data protection principles. Thus, if photos are taken and shared between family members for a family journal or other private purposes, the principles have no application for such personal information. Further exemption is provided by s 37 for miscellaneous exemptions.

In one way or another, the existence of data protection legislation affords protection for informational privacy though it was not intended to be specific privacy legislation. However, many questions remain about how adequately it addresses claims for breach of privacy.

For the purpose of comparison and enhancement of data protection law in Malaysia, the following part discusses similar law sanctioned in New Zealand albeit with a different name: the Privacy Act 1993.

\section{Privacy Act 1993}

\section{A Introduction}

In New Zealand, the most relevant legislation that provides protection of an aspect of privacy rights is the Privacy Act 1993 (PA). It came into force on 1 July 1993 to promote and protect individual privacy and to respect the transborder flows of personal data in general accordance with the guidelines of the

\footnotetext{
${ }^{108}$ The Law of Privacy and The Media, above 86 at 309-310.
} 
Organisation for Economic Co-operation and Development. ${ }^{109}$ It deals primarily with the protection of informational privacy and establishes certain principles at the core of the Act which regulate personal information. A breach of the principles constitutes an interference with the privacy of an individual.

The objective of the Act is to promote and protect individual privacy in general $^{110}$ and to establish certain principles governing the collection, use and disclosure by public and private sector agencies of an individual's personal information in particular. It also appoints a Privacy Commissioner to investigate complaints of interference with an individual's privacy.

However, the PA does not create any general right to privacy. It does not provide protection for privacy generally as suggested by its name; indeed it was introduced as a key requirement for New Zealand to comply with the European Data Protection Directives 1995. The same requirement influenced Malaysia when it introduced the PDPA with its aim to satisfy minimum legal requirements governing the collection and processing of personal data. It is important to note that from three laws from different jurisdictions, only the Privacy Act 1993 comprehensively covers one aspect of privacy interests more than those of the other two jurisdictions.

This Part examines the coverage of the PA in addressing breach of data privacy particularly involving disclosure of personal information. This examination is useful for developing Malaysian data protection law.

\footnotetext{
${ }^{109}$ Guidelines on the Protection of Privacy and Transborder Flows of Personal Data < www.oecd.org> New Zealand adopted the Guidelines on 23 September 1980.

${ }^{110}$ The protection is in accordance with the Recommendation of the Council of the Organisation for Economic Co-operation and Development Concerning Guidelines Governing the Protection of Privacy and Transborder Flows of Personal Data.
} 
The scope of the Act is wide and applies broadly to governmental bodies, private business, societies, clubs and non-profit organisations as long as their activities relate to the handling of an individual's information. ${ }^{111}$ Hence, the Act brings within its ambit public and private organisations alike and applies privacy principles to each indiscriminately. However, the news media are excluded from the definition of "agency" in respect of their news activities ${ }^{112}$ and are exempt from the Act's principles.

The focus of the Act is on privacy of personal information and works on a principle-based approach. ${ }^{113}$ The definition of "personal information" is central to the scope of the Act as a whole, since the privacy principles apply only to information that is "personal information". "Personal information" is defined as: ${ }^{114}$
information about an identifiable individual; and includes
information relating to a death that is maintained by the
Registrar-General pursuant to the Births, Deaths, Marriages,
and Relationships Registration Act 1995, or any former Act.

\footnotetext{
${ }^{111}$ Section 2 provides "Agency means any person or body of persons, whether corporate or incorporate, and whether in the public sector or the private sector...". The same provision also expressly stated that the Sovereign, the Parliament, a court or tribunal or a Royal Commission or commission of inquiry and the news media in relation to news activities are not agency under the Act.

${ }^{112}$ Section 2(1)(b)(xiii) defines "news activity" as (a) the gathering of news, or the preparation or compiling of articles or programmes of or concerning news, observations on news, or current affairs, for the purposes of dissemination to the public or any section of the public; (b) the dissemination, to the public or any section of the public, of any article or programme of or concerning - (i) news:(ii) observations on news:(iii) current affairs.

${ }^{113}$ See New Zealand Law Commission Study Paper Review of Privacy Act 1993 - Review of the Law of Privacy Stage 4 (NZLC, Wellington, 2010) at 43-44. The principle-based approach refers to a flexible, open-textured approach to regulating the collection, use, disclosure of personal information based on a set of 12 privacy principles provided in the Act.

${ }^{114}$ Section 2 of the Act.
} 
This definition is broad and not limited to information that is sensitive, intimate or private. ${ }^{115}$ The word "identifiable individual" indicates that identification is regarded as a requirement for the application of the Act.

The Privacy Act, unlike similar statutes in other jurisdictions, does not have a separate category of "sensitive information". All personal information is treated in the same way under the Act. In contrast, under the PDPA, the processing of sensitive personal data is permitted provided that it is carried out in accordance with the provision of s 40 of the PDPA. In this regard, the DPA has considered certain kinds of information as sensitive personal data. ${ }^{116}$

The Privacy Act 1993 is, undoubtedly, the most significant legislation about privacy. It expressly provides for the protection of an aspect of privacy interest, namely informational privacy. However, in the context of its application, it is not an adequate framework for the protection of a general right to privacy. It does not deal with other aspects of privacy, such as bodily intrusion. Nevertheless, the Act works well in relation to personal data protection, and provides a broad range of protection including collection, storage and security of personal information, the right of access to information, and a limit on the use and disclosure of personal information.

\footnotetext{
${ }^{115}$ Refer Stephen Penk and Rosemary Tobin (eds) Privacy Law in New Zealand (Brookers Ltd, Wellington, 2010) at 59; See also Paul Roth "What is 'Personal Information'?” (2000) 20 NZULR 40.

${ }^{116}$ See s 2 DPA 1998. The Act categorised information relating to the racial or ethnic origin, political opinion, religious belief, membership of a trade union, physical or mental health or condition, sexual life, commission or alleged commission of any offence and any proceedings for any offence committed or alleged to be committed by the data subject as sensitive personal data.
} 


\section{Information privacy principles}

Personal information must be handled in accordance with 12 information privacy principles set out in s 6 of the Act. ${ }^{117}$ These principles are concerned with how personal information may be collected, held, used and disclosed and are the fundamental focus of the Act. It is principally concerned with how agencies collect and store information about people, the security of that information, and how it is to be used. Based on this concern, the primary aim of the Act is always the protection of personal information rather than other privacy interests.

The Act incorporates twelve information privacy principles. Principle 1 allows for the collection of lawful personal information and is directly related to the agency's functions or activities. Under Principle 2, the agencies must collect personal information from the individual to whom the information relates, unless certain exceptions apply. ${ }^{118}$ It follows that any information collected from any other person other than the individual whose information is collected, it is not authorised by the Act. Thus, a breach occurs if $\mathrm{C}$ collects information about A from B, and not directly from A.

Principle 3 states that when personal information is collected from the individual concerned, that individual must (unless certain exceptions apply) be made aware of such matters as the fact that the information is being collected, the purpose for which it is being collected, and the intended recipients of the information. ${ }^{119}$ The agency must take reasonable steps to ensure that the person whose information is collected is informed of the terms related to the collection, such as its purpose, who will get the information and

\footnotetext{
${ }^{117}$ Discussion in this section is mainly based on the information privacy principles provided under s 6. Reference is also made to New Zealand Law Commission Study Paper, above n 113.

${ }^{118}$ See New Zealand Law Commission Study Paper, above n 113, at 74-75.

${ }^{119}$ See New Zealand Law Commission Study Paper, above n 113, at 74-75.
} 
what consequences occur if the information is not provided. ${ }^{120}$ This principle is intended to safeguard the interest of the individual concerned.

The manner by which the data is collected is defined in Principle 4 which states that agencies must not collect personal information by unlawful or unfair means, or in unreasonably intrusive circumstances. Para (b)(ii) of Principle 4 expressly prohibits "intrusion to an unreasonable extent upon the personal affairs of the individual concerned" which provides an element of protection against privacy invasion.

In terms of security, Principle 5 warns agencies that hold personal information to take reasonable steps secure it against loss, unauthorised access, use, modification or disclosure, or other misuse. An agency must do everything reasonably necessary to prevent unauthorised use or unauthorised disclosure of information in a situation where transmission of information is required in the course of business. ${ }^{121}$

In relation to Principle 5, the right to access to personal information is stated under Principle 6 where an individual is entitled to obtain confirmation from an agency as to whether or not the agency holds that individual's personal information and, if the agency does hold such information, the individual is entitled to have access to it. However, there are certain grounds on which an agency can refuse to provide an individual with access to his or her personal information. ${ }^{122}$

Any information given may be corrected if an individual thinks it is wrong. Principle 7 states that if an agency holds an individual's personal information, the individual is entitled to request that the agency correct that information. If

\footnotetext{
${ }^{120}$ Section 6, Principle 3.

${ }^{121}$ Section 6, Principle 4 (a)-(b).

${ }^{122}$ New Zealand Law Commission Study Paper, above n 113, at 75. Part 4 of the Act provides grounds on which access to personal information may be refused such as security, defence, international relations, trade secrets etc.
} 
the agency does not so agree, it must take reasonable steps to attach a statement of the correction sought but not made to the information. ${ }^{123}$ With regard to the accuracy of the information, Principle 8 states that before using such information an agency must take reasonable steps to ensure that the information is accurate, up-to-date, complete, relevant and not misleading. ${ }^{124}$

Although there is no definite time-frame for holding of the information, Principle 9 cautions agencies not to retain personal information for longer than is required for the purposes for which it may lawfully be used. ${ }^{125}$ It should be kept only for as long as is necessary to carry out the purpose for which the agency originally obtained the information. Principle 10 provides that agencies must use personal information for the same purpose for which they obtained that information. Other uses are occasionally permitted if it is necessary to enforce the law, or if the use is directly related to the purpose for which the agency obtained the information. ${ }^{126}$

Disclosure of information may be made in limited circumstances only. Principle 11 states that an agency must not disclose personal information unless certain exceptions apply. For example, an agency may disclose information if it reasonably believes that disclosure is one of the purposes for which it obtained the information, or that disclosure is necessary to uphold or enforce the law, or for a court proceeding, or that the person concerned authorised disclosure, or that the information is used in a form that does not identify the person concerned. ${ }^{127}$

Principle 12 places restrictions on the use of "unique identifiers" such as IRD numbers or credit card numbers. The principle restricts the ways in which

\footnotetext{
${ }^{123}$ Section 6, Principle 7. See also New Zealand Law Commission Study Paper, above n 113, at 93-94.

${ }^{124}$ Section 6, Principle 8.

${ }^{125}$ Section 6, Principle 9.

${ }^{126}$ Section 6, Principle 10. It provides the limits on use of personal information, see (a)-(g).

${ }^{127}$ Section 6, Principle 11 (a)-(h).
} 
agencies may assign such numbers to individuals, and the circumstances in which they may require individuals to disclose such numbers. ${ }^{128}$

It is vital to highlight that Principles 10 and 11 do not confer on any person legal rights and are not enforceable in a court of law as stated in s 11(2). Those who are affected by a breach of the principles in the Act can make a complaint to the Privacy Commissioner under s 67 alleging an interference with privacy. ${ }^{129}$ The Commissioner has the power to investigate the action, but can also refer the complaint to an Ombudsman, ${ }^{130}$ the Health and Disability Commissioner ${ }^{131}$ or the Inspector-General of Intelligence and Security, ${ }^{132}$ and if the Commissioner is not able to secure a settlement of the complaint following the investigation, civil proceedings before the Human Rights Review Tribunal may be instituted pursuant to $s$. The Tribunal may grant a range of remedies if it is satisfied on the balance of probabilities that there has been an interference with the complainant's privacy. ${ }^{133}$

Section 14 of the Privacy Act expressly upholds the importance of privacy and other human rights and provides a balancing exercise in any event of

\footnotetext{
${ }^{128}$ New Zealand Law Commission Study Paper, above n 113, at 75.

${ }^{129}$ Section 67 provides that (1) Any person may make a complaint to the Commissioner alleging that any action is or appears to be an interference with the privacy of an individual. (2) A complaint under this Part may be lodged with the Commissioner or an Ombudsman. (3) On receiving a complaint under this Part, an Ombudsman shall forward the complaint to the Commissioner as soon as practicable.

${ }^{130}$ Section 72 on Referral of complaint to Ombudsman. The Commissioner shall consult with the Chief Ombudsman in order to determine the appropriate means of dealing with the complaint relates to a matter under the Ombudsmen Act 19975 or the Official Information Act 1982 or the Local Government Official Information and Meetings Act 1987.

${ }^{131}$ Section $72 \mathrm{~A}$ on Referral of complaint to Health and Disability Commissioner. The Commissioner shall consult with the Health and Disability Commissioner in order to determine the appropriate means of dealing with the complaint relates to a matter under the Health and Disability Commissioner Act 1994.

${ }^{132}$ Section $72 \mathrm{~B}$ on Referral of complaint to Inspector General of Intelligence and security. The Commissioner shall consult with the Inspector-General of Intelligence and Security in order to determine the appropriate means of dealing with the complaint relates to a matter under the Inspector-General of Intelligence and Security Act 1996.

${ }^{133}$ Section 85 on Powers of Human Rights Review Tribunal. If, in any proceedings under section 82 or section 83 , the Tribunal is satisfied on the balance of probabilities that any action of the defendant is an interference with the privacy of an individual, it may grant one or more of the remedies provided in the Act.
} 
competing interest between privacy and other rights. Thus, in exercising his or her functions, the Commissioner must have due regard for the protection of important human rights and social interests that compete with privacy, including the general desirability of a free flow of information and the recognition of the right of government and business to achieve their objectives in an efficient way. ${ }^{134}$

With the aim of providing substantial protection of informational privacy, the twelve information privacy principles establish a framework for limiting the use and disclosure of personal information and specify a breach of the principles as an interference with individual's privacy.

\section{Exemption and enforcement}

With regard to exemptions, s 56 provides that the information privacy principles do not apply to the collection of personal information by an individual, or to the holding of personal information by an individual, where that personal information is collected or held solely or principally for the purposes of, or in connection with, the individual's personal, family or household affairs. The Act also has no application to news media because the definition of "agency" in s 2 excludes any news medium in relation to its news activities. This exemption precludes a complaint against the news media. $^{135}$

Section 11(1) provides that an entitlement given to individual by subclause (1) of principle 6 may be enforced in a court of law provided that the agency concerned is a public sector agency. In other situations such as non-

\footnotetext{
${ }^{134}$ Section 14(a).

${ }^{135}$ See also Penk and Tobin, above n 115, at 71.
} 
compliance with Principles 10 and 11, the Act does not confer on any person any legal right enforceable in a court of law. ${ }^{136}$

The privacy of an individual is interfered with if an agency breaches any information privacy principle and the individual suffers harm as a result of the breach. For an interference to arise, s 66(1)(a) requires that there be a breach by an agency of an information privacy principle, or of a code of practice, or of the provisions of Part 10 of the Act (relating to information matching). It is not only that the breach has occurred, but it must also be satisfied that the breach by the agency has caused, or may cause, loss, detriment, damage, or injury to the individual, or has adversely affected, or may adversely affect, the rights, benefits, privileges, obligations, or interests of the individual, or has resulted in, or may result in, significant humiliation, significant loss of dignity, or significant injury to the feelings of the individual. ${ }^{137}$

\section{Remedying the Defects}

This Part discusses flaws inherent in the PDPA and suggestions for its improvement. Specific reference to the DPA and PA is necessary in order that the application and enforcement of the Act could be improved in the future.

The passing of the much awaited PDPA is a result of a great effort by the government in relation to the processing and use of personal data. Malaysia is the first ASEAN country to have a specific data protection law. It is hoped that it will become a model for the development of such laws in other ASEAN member states. However, an analysis of the Act finds room for improvement.

The obvious shortcoming of the Act is the definition of personal data. It is interesting to note that the Act applies only to commercial transactions

\footnotetext{
136 At 77.

${ }^{137}$ Section 66(1)(a)-(b). See also Penk and Tobin, above n 115, at 61.
} 
although the precedents that inspired the Act are generally applicable to all situations. Similarly neither DPA nor the PA has separated personal data categories into commercial or non-commercial categories. All personal data is treated equally and subject to the same requirements of the Act. There seems to be no principled reason why the PDPA limits its scope only to commercial transactions. This may be because the introduction of the Act is essentially aimed at meeting the European Union's data protection requirements. If the PDPA continues to be applied in its current form, little is protected.

The non-applicability of the PDPA to Federal and State governments as highlighted by s 3 raises a concern as to different standards governing the data of public and private bodies. What kind of protection is available if the data user is dealing with the government with regard to the same data? The fact that the Act does not bind the government results in double standards in the treatment the same data. ${ }^{138}$ The application of different standards, fails to achieve full protection of personal data. However, according to the Information, Communications, Culture and Arts Minister Datuk Seri Dr Rais Yatim, the reason why the Act binds only the private sector is because safeguards already exist which take care of government channels compared with insufficient regulations concerning the use of personal data in the hands of irresponsible people. He stated that the government already possesses the relevant authorities and legal controls and parameters such as the Official Secrets Act, and laws pertaining to creditors. ${ }^{139}$

\footnotetext{
${ }^{138}$ Unlike those precedents that the Act referred to which provide the protection of data in both public and private sectors. South Korea for example, has two separate laws that govern these two different sectors. The Act on the Promotion of Information and Communications Network Utilization and Information Protection provides guidelines for personal information in the private sector whereas the Protection of Personal Information Maintained by Public Agencies Act was introduced to govern the personal information protection in public sector. Refer to Chang-Boem Yi and Ki-Jin Ok "Korea's personal information protection laws" (2003) PLPR 8.

${ }^{139}$ Yeng Ai Chun "Personal Data Protection: Government has own mechanism" The Star Online (Malaysia, 15 July 2009) <http://archives.thestar.com.my>. Laws pertaining to creditors include the Pawnbrokers Act 1972, the Hire Purchase Act 1967 and the Moneylenders Act 1951 (Malaysia).
} 
The Official Secrets Act 1972 protects the government's official secrets whereas the PDPA aims at protecting personal data in commercial transactions. These two laws do not have the same objective. The exclusion of the public sector, therefore, from the purview of the PDPA on the basis that protection is provided by the Official Secrets Act does not address the problem of different standards when dealing with personal data and the absence of protection for individuals whose personal data is held by government.

In comparison, the DPA and PA apply to both public and private bodies. As far as processing of personal data and information is concerned, governments, corporations, partnership public and private agencies are subject to the same legislation in the UK and NZ respectively. This comprehensive application of the personal data law to public and private sectors should be adopted in Malaysia if the existing framework aims to fairly protect an aspect of privacy interest to all parties.

Though data should be protected as part of an individual's right to privacy, this Act is not privacy-driven because it discusses provisions for personal data protection in relatively few sections ${ }^{140}$ and the remaining provisions provide and explain the administration and maintenance of the system of handling of personal data. The ultimate end of protection - redress for individuals is absent from the Act. It contains no provision for compensation for an individual whose data has been misused. Though it grants correction of inaccurate information, ${ }^{141}$ the main focus of the Act is on sanctions for breach. ${ }^{142}$ This may provide some deterrence against breach, but does not compensate the victim. Due consideration should thus be given to ensure fair treatment to data subjects because fine or imprisonment of the data user is

\footnotetext{
${ }^{140}$ The Act points out on personal data protection principles in sections 5 to 12 and on rights of data subject in ss 30 to 44 of the PDPA 2010.

${ }^{141}$ Section 34 on the right to correct personal data.

${ }^{142}$ Section $5(2)$.
} 
poor consolation for the subject whose data has been processed or released without consent.

The PDPA should provide specifically for private remedies such as damages with financial compensation and injunctions to data subjects affected as a result of a breach of privacy. This will encourage compliance and restrain further invasion and is in line with international precedents which provide compensation for individuals who have suffered distress caused by contravention by the data controller. ${ }^{143}$ In the UK, while there are no guidelines in the DPA as to the appropriate level of compensation for a claim, judges have discretion and when assessing damages for distress take into consideration many factors including the seriousness of the breach and its effect upon the claimant. ${ }^{144}$ For example in the case of Jacklyn Adeniji $v$ Newham Council, ${ }^{145}$ the High Court awarded the claimant $£ 5,000$ in damages and $£ 50,000$ for legal costs for breach under the DPA and the Human Rights Act 1998 after her photograph was used without permission. Another case where the court awarded damages for breach under the DPA was Campbell $v$ Mirror Group Newspapers ${ }^{146}$ where Morland J awarded damages of $£ 3,500$ for breach of confidence and breach of duty under s 4(4) of the DPA.

Similarly, the PA clearly provides remedies that may be sought by the aggrieved party in cases of breach of information privacy principles. ${ }^{147}$ The Human Rights Review Tribunal may grant remedies such as a declaration, an order restraining the continuation of the interference, damages, an order to perform specific acts or other relief. ${ }^{148}$ Section 88 gives power to the Tribunal

\footnotetext{
${ }^{143}$ This is provided under s 13 of the Data Protection Act 1998 (UK) and s 66 of Hong Kong Personal Data (Privacy) Ordinance 1995.

${ }^{144}$ Refer to leaflet by Information Commissioner's Office (UK). < http://www.ico.gov.uk $>$

${ }^{145}$ October 2001, High Court hearing.

${ }^{146}$ [2002] EWHC 499 (QB).

${ }^{147}$ Section 84.

${ }^{148}$ Section 85 .
} 
to award damages against the defendant for an interference with the privacy of an individual in situations where: ${ }^{149}$

(a) pecuniary loss suffered as a result of, and expenses reasonably incurred by the aggrieved individual for the purpose of, the transaction or activity out of which the interference arose;

(b) loss of any benefit, whether or not of a monetary kind, which the aggrieved individual might reasonably have been expected to obtain but for the interference;

(c) humiliation, loss of dignity, and injury to the feelings of the aggrieved individual.

The above provision adequately addresses the issue of remedy absent in the PDPA. The experience of the UK law and NZ in providing protection to the aggrieved individual particularly in terms of remedy is a good example for the improvement of data protection law in Malaysia.

With regard to enforcement, the position of the Commissioner as a body corporate and subservient to the Minister shows a lack of functional independence. In terms of the nature of the duties and powers assigned by the Act, the Commissioner should be independent and made accountable directly to the Parliament. The importance of the Commissioner's position in relation to personal data protection issues requires greater accountability in the discharge of his duties.

Under the DPA, the Information Commissioner is an independent official whose legal personality is a corporation sole. ${ }^{150}$ The Commissioner is answerable directly to Parliament and not to a Minister. The Commissioner exercises legal powers vested directly in him and not delegated by a

\footnotetext{
${ }^{149}$ Section 88(1) (a)-(c). For a detail discussion on remedies under the Privacy Act 1993, refer Katrine Evans "Show Me the Money: Remedies under the Privacy Act" (2005) 36 VUWLR 475.

${ }^{150}$ Part 1, Schedule 5 at [1] of the DPA 1998.
} 
Minister ${ }^{151}$. Under s 52, the Commissioner is required to set down an annual report before Parliament concerning the exercise of his function under the DPA.

The Privacy Commissioner under the PA is an independent Crown Entity ${ }^{152}$ with numerous functions under $\mathrm{s}$ 13. The Commissioner must act independently in performing statutory functions and duties. Reports must be made from time to time to the responsible Minister or the Prime Minister. The Act expressly provides that the Commissioner is responsible for safeguarding the information privacy interests of an individual by having due regard for the importance of human rights and social interests that compete with privacy, including the general desirability of a free flow of information and the recognition of the right of government and business to achieve their objectives efficiently. ${ }^{153}$

The exclusive function of the NZ Privacy Commissioner concerning the protection of individual privacy is not among the Commissioner's duty in Malaysia and the UK. This illustrates another failure of the Malaysian personal data law to provide protection for privacy interests and this important function should be considered when making improvements to the law.

The PDPA's fundamental motive is towards enhancing the security, integrity and protection of personal data but it offers no further protection for a general right to privacy as defined by this thesis. It is apparent, therefore, that the PDPA is not adequate to provide protection against breach of privacy.

In short, if Malaysia is to have a comprehensive protection system for processing and handling personal data, these flaws must be addressed. Both

\footnotetext{
${ }^{151}$ See Data Protection Law and Practice, above n 45, at 768-769.

${ }^{152}$ Section 12 of the Privacy Act 1993 (NZ).

${ }^{153}$ Section 14(a).
} 
the UK Data Protection Act 1998 and the New Zealand Privacy Act 1993 can assist in the development of a better law for data protection in Malaysia.

\section{Conclusion}

Examination of the existing statutes for the protection of privacy in Part II demonstrates that the laws are piecemeal and indirect. Privacy is not the focus of these laws, although it may contribute to a more general protection within the law. For example, as discussed in the criminal law section, the protection of a person's modesty and dignity is the aim of ss 292 and 509 of the Penal Code, but many significant acts of intrusion such as surveillance, unwanted touching and listening, fall outside it. The Child Act 2001 protects the interest and privacy of children but although this provides important protections, it only covers intrusion by the media. Similarly, the National Land Code 1965 protects an individual's right to property by providing an absolute control over the land but the provision does not give the person a right to privacy; rather it secures his right to property through a control mechanism.

The introduction of the PDPA has, due to its limitations, not remedied the inadequacies of privacy protection. References and analysis of the law on data protection of the two model countries provide a useful approach to how the PDPA should be improved to include maximum protection for the privacy of personal information. Although it is obvious that the DPA and PA are not capable of providing protection of private information as defined in this thesis, they both address the protection of personal data more comprehensively than Malaysia. Analysis of the two statutes from UK and NZ suggests that many aspects of data protection need to be improved by the Malaysian PDPA. 
It is significant that the NZ law is the most appropriate model for Malaysia to review and revise its law. The analysis of the laws in all three jurisdictions reveals that the focus of data protection law is the handling and processing of personal information. However, the NZ Privacy Act states explicitly that the law's aim is to promote and protect individual privacy in general. Overall reading and analysis of the PA confirms why the Act was called Privacy Act and not the Data Protection Act. In enforcing its principles the PA always has regard to the protection of privacy and expressly provides for the effect of a breach ie infringement of an individual's privacy. Thus, the protection offered by the PA is more akin to protection of privacy interests generally as compared with the DPA and PDPA, which focus solely on the management and processing of personal data in accordance with the rules and procedures.

In conclusion, reliance on the existing statutes to protect privacy will not serve the aim of privacy protection. Due to its limitation in scope and application, the introduction of the PDPA did not resolve the matter. Although neither the DPA nor the PA has provided adequate protection for private information, both are far better than the PDPA. They provide guidance for Malaysia to rectify the defects, but even if Malaysia rectifies them, the newly revised PDPA still lacks ability to protect infringement of privacy. This justifies the need for a specific law on privacy as proposed by this thesis.

As discussed earlier, when developing such a law (or indeed the common law protections of privacy), it is important to draw on the experience of other jurisdictions. The following chapter, therefore, discusses the state of privacy protection and its development in English law and examines how privacy action was formulated. 


\section{PART III: COMPARATIVE MODELS}

CHAPTER FIVE

\section{PROTECTION OF PRIVACY INTERESTS IN ENGLISH}

LAW

\section{Overview}

The aim of this chapter is to provide an analysis of the development of the privacy action in England and in particular the development of a right to privacy within the breach of confidence action. This chapter argues that the formulation of a privacy action and its requirements are of utmost importance for developing the same action in Malaysia. Under English law an action for wrongful publication of private information may be sought. The recognition of such an action proves the court's role in developing the law in this area. The development of the English privacy framework provides a useful model for Malaysia for three reasons.

First, as discussed in Chapter Three, the application of English law in Malaysia did not stop on 7 April 1956 as stated in s 3 of the CLA 1956. It has continued as a source of reference although Malaysia has been under no obligation to follow. It is unsprising, therefore, when occasionally it has been followed entirely and formed the reason for a decision such as occurred in Ultra Dimension. ${ }^{1}$ Thus, the development of privacy protection in English private law since Douglas will undoubtedly be referred to when similar issues are raised in the Malaysian courts in the future.

Second, in certain areas of law such as privacy, judges' interpretation and understanding of the nature of the relevant issues greatly contribute to the

\footnotetext{
${ }^{1}$ See above $\operatorname{ch} 3, \mathrm{n} 98$.
} 
development of the law itself. There was an opportunity to develop a privacy action in Malaysia initiated in Maslinda Ishak, ${ }^{2}$ and if this route followed in the future, the shift in Douglas and other $v$ Hello! $L t d,{ }^{3}$ and the formulation of a privacy action in Campbell $v$ MGN Ltd ${ }^{4}$ would be constructively relevant for Malaysian courts. Third, the requirement of a privacy action that focuses on the test of reasonable expectation of privacy as the sole determinant factor for liability in privacy is flexible and inherently well-suited to respond to unforeseen privacy threats. ${ }^{5}$ Moreover, given the fact that the concept of reasonableness ${ }^{6}$ and the reasonable person are familiar tests in negligence and other private law cases in Malaysia, it would be easier for judges to apply the reasonable expectation of privacy test and to utilise its flexibility in privacy cases.

In the past decade, there have been a number of key developments of the protection of privacy in the United Kingdom. The significant case of Campbell marked the rapid development of privacy rights in the UK. All five judges ${ }^{7}$ agreed that English law recognises a right to protection of private information. Lord Hoffman stated: ${ }^{8}$

the difference of opinion relates to a very narrow point which arises on the unusual facts of this case... But the importance of this case lies in the statements of general principle on the way in which the

\footnotetext{
${ }^{2}$ Above ch 3, n 14 .

${ }^{3}$ [2001] QB 967; [2001] 2 WLR 992 (Douglas).

${ }^{4}$ [2004] UKHL 22; [2004] 2 AC 457 (HL) (Campbell).

${ }^{5}$ See The Law of Privacy and The Media, above ch 4, n 86, at 229.

${ }^{6}$ See Chris DL Hunt "Privacy in the Common Law: A Critical Appraisal of the Ontario Court of Appeal's Decision in Jones v Tsige" (2012) 37(2) Queen's LJ 661, at 684-685. The author referred to NSWLRC Report and stated that among the advantages of the reasonable expectation of privacy test is owing to its "open texture" approach and the familiarity of the test to judges. She said, because judges are well-versed in the concept of reasonableness, given its wide applicability in other areas of private law, this test fits in with established tort principles.

${ }^{7}$ Their Lordships in Campbell are Lord Nicholls of Birkenhead, Lord Hoffman, Lord Hope of Craighead, Baroness Hale of Richmond and Lord Carswell.

${ }^{8}$ Campbell, at [36].
} 
law should strike a balance between the right to privacy and the right to freedom of expression, on which the House is unanimous.

This position undoubtedly was a result of a journey to privacy recognition in English law since Kaye v Robertson. ${ }^{9}$ The introduction of the Human Rights Act 1998 (the HRA) which had the effect of incorporating the European Convention of Human Rights and Fundamental Freedoms (the Convention) into domestic law, the extension of the traditional action for breach of confidence and the incorporation of the European jurisprudence are major factors influencing the development.

This chapter discusses the law of privacy in the United Kingdom. Part II considers the common law protection of privacy and traditional breach of confidence action. The existing common law principles which have a bearing on privacy interests are discussed in order to analyse the previous reluctance to recognise a separate tort of privacy as part of the law. Part III evaluates breach of confidence post-HRA and the impact of the HRA in privacy cases. The utilisation of a breach of confidence action to accommodate privacy breaches and its new methodology which expands the boundary of confidentiality to personal information are examined in this Part. The incorporation of the Convention rights has greatly changed the landscape of privacy law by providing an opportunity for significant development of the right. Part IV discusses the tort of misuse of private information as recognised in Campbell and its elements to define the tort. The application of the test of reasonable expectation of privacy and other tests in determining privacy cases are analysed in the light of Campbell and other subsequent cases. This Part also highlights the protection against physical privacy and remedies in privacy action. Part V concludes the discussion of English privacy law.

\footnotetext{
${ }^{9}$ Kaye v Andrew Robertson [1991] FSR 62 (Kaye).
} 


\section{The Framework for the Protection of Privacy}

In this Part, the existing common law protections grounded in trespass, nuisance, defamation, copyright, malicious falsehood are discussed to assess how the previous framework had provided remedies for breach of privacy, and to acknowledge the existence of a patchy form of privacy protection. This Part also analyses the applicability of the traditional breach of confidence to privacy actions.

Previously, there was no general law of privacy in English law. Consequently, the courts were not actively involved in construing the right of privacy as a recognised cause of action. The hesitation to enlarge the ideas of privacy were restated in Malone v Metropolitan Police Commissioner where the court held that English common law did not recognise a cause of action for the infringement of telephonic privacy. ${ }^{10}$

Another strong authority which confirmed this position is Kaye. In that case, the plaintiff, Mr Kaye, a well-known actor, applied for an order restraining the publication of photographs, obtained by a tabloid's journalist, of injuries he sustained in a car crash while he was still in hospital undergoing treatment. The Court of Appeal commented on the defendant's action as "a monstrous invasion of privacy". ${ }^{11}$

The inadequacies of English law to address privacy matters in that case were commented on by Bingham LJ: ${ }^{12}$

This case nonetheless highlights, yet again, the failure of both the common law of England and statute to protect in an effective way the personal privacy of individual citizens... If ever a person

\footnotetext{
${ }^{10}$ Malone v Metropolitan Police Commissioner [1979] Ch 344.

${ }^{11}$ Kaye, above n 9, at 70 .

${ }^{12}$ At 70 .
} 
has a right to be let alone by strangers with no public interests to pursue, it must surely be when he lies in hospital recovering from brain surgery and in no more than partial command of his faculties. It is this invasion of his privacy which underlies the plaintiff's complaint. Yet it alone, however gross, does not entitle him to relief in English law.

The court acknowledged that the defendant's act was an invasion of the plaintiff's privacy and yet concluded that only malicious falsehood was applicable to the circumstances of the case and decided that the invasion of privacy was not actionable and that generally no tort of privacy existed in English law. The court chose to apply the inadequate level of protection provided under recognised torts rather than take the bold step of recognising a tort of privacy. The decision prevented any potential for developing remedies against privacy intrusions.

The above status continued in the case of Wainwright $v$ Home Office ${ }^{13}$ where the Law Lords refused to recognise the existence of a separate and freestanding tort of privacy, relying upon the progressive extension of the existing breach of confidence action to protect privacy interests. In that case, counsel for the plaintiffs attempted to obtain a remedy for the intrusive strip-search to which they had been subjected, by arguing that various torts of intentional interference with the body of a person should be given an expanded definition to protect personal privacy, or alternatively, that an autonomous tort of privacy should finally be recognised in English law.

Since the incident had taken place in 1997, before the HRA came into force, art 8 of the Convention could not be directly invoked against the authorities responsible for the detention, and no alternative avenue was available to the

\footnotetext{
${ }^{13}$ Wainwright v Home Office [2003] UKHL 53; [2004] 2 AC 406 (HL) (Wainwright). Lord Hoffmann who gave the leading judgment for the House of Lords, held that although the breach of confidence action provides some protection against the disclosure of personal information, there is no general tort of invasion of privacy in English law, at [30-35].
} 
plaintiffs in English law. The court held that there was no common law tort of invasion of privacy and that the creation of such a tort required a detailed approach which could be achieved only by legislation rather than the broad brush of common law principle. ${ }^{14}$ On that basis, the court concluded that protection for such situations should be left to Parliament to fill the gap with a statutory provision.

\section{A Common law}

Although it is settled that the current legal position now for the protection of privacy under the English law is the utilisation of breach of confidence action, it is necessary to briefly discuss the role of common law principles in protecting privacy before the HRA came into force. The discussion is relevant because reliance on common law principles in addressing privacy cases has been the means of protecting privacy in Malaysia and was confirmed in Ultra Dimension.

The common law has always offered piecemeal protection to many aspects of private life. This raises the question as to the extent the existing laws protect infringement of privacy. In the absence of a tort of privacy, the courts are able to develop the common law by depending on existing principles in the law of trespass, nuisance, copyright, defamation, malicious falsehood, the law of passing off, breach of confidence and the like to fashion a common law right to privacy. ${ }^{15}$ Analysing each principle that constitutes a common law action, shows that none of them are able to protect privacy beyond what a breach of confidence law can provide.

This Part discusses those common law principles that illustrate Malaysia's inadequacy to provide protection to aspects of privacy interests. It confirms

\footnotetext{
${ }^{14}$ At [33].

${ }^{15}$ Jonathan Morgan in "Privacy, Confidence and Horizontal Effect: "Hello" Trouble" (2003)

62 Cambridge LJ 444 at 458.
} 
that reliance on them does not remedy the inadequacies of privacy protections and thus, that a different approach needs to be undertaken to protect privacy of individuals.

The law of trespass to a person and to land requires direct physical interference with the person or the land. A remedy for physical intrusion may be sought only by an owner or a person who is in the possession of the land. Thus in Kaye, a claim for physical intrusion could have been brought by the hospital authorities, but not by the patient, against the journalist and photographer who entered the patient's room without permission from the hospital's staff. Here, the common law principle of trespass could not serve the purpose for which an action for privacy intrusion is brought because in certain circumstances, privacy intrusion takes place without any direct physical interference.

The ability of private nuisance to provide protection for privacy was also examined. The Younger Report found that private nuisance was not a particularly effective cause of action for the protection of privacy interests. It stated: ${ }^{16}$

An action for private nuisance is normally brought for some physical invasion of the plaintiff's land by some deleterious subject matter...in circumstances that would not amount to trespass to land. It is much more doubtful if it would cover an activity which had no physical effect on the plaintiff's land, although it detracts from the plaintiff's enjoyment of that land.

Further, only the person who has an interest in the land affected by the nuisance can bring the action, and accordingly this tort is of little use in protecting victims of infringement of privacy. In Hunter $v$ Canary Wharf Ltd

\footnotetext{
${ }^{16}$ Report of the Committee on Privacy (Cmnd 5012) (1972).
} 
the court held that the law of nuisance would not provide any protection to any guests or friends visiting of the property owner, if they had no interest in the surveyed land. ${ }^{17}$

The tort of defamation which consists of libel and slander focused on the claimant's public reputation and not his personal honour or dignity. Thus publication to a third party is a prerequisite before an action can be sustained. Defamation and invasion of privacy have some elements in common but are not identical. The Younger Committee recommended that "the concept of defamation and privacy should be kept distinct from one another." 18 The defamation case of Tolley $v$ Fry \& Sons Ltd $^{19}$ led Winfield to argue that English law should recognise a right to privacy. ${ }^{20}$ The main problem is that truth is a complete defence to an action in defamation yet it is often the publication of true personal information which causes the greatest distress.

Some commentators have agreed that among other causes of action, the law of confidence has a close connection to privacy and is therefore, more able to flexible to protect it. ${ }^{21}$ Lord Hoffman in Campbell stated that despite the absence of a general tort of invasion of privacy as confirmed in Wainwright, the right to privacy is in a general sense one of the values, and sometimes the most important value, which underlies a number of more specific causes of action, both at common law and under various statutes. He emphasised that an

\footnotetext{
${ }^{17}$ Hunter v Canary Wharf Ltd [1997]AC 655.

${ }^{18}$ Report of the Committee on Privacy, above n 19, at [71]-[72].

${ }^{19}[1931]$ AC 33 .

${ }^{20} \mathrm{P}$ Winfield, "Privacy" (1931) LQR 23.

${ }^{21}$ See Helen Fenwick and Gavin Phillipson, "Confidence and Privacy: A Re-Examination" (1996) 55 Cambridge LJ 447; Ng-Loy Wee Loon "Emergence of a right to privacy from within the law of confidence?" (1996) 18(5) European Intellectual Property Rev 307, at 310 "The law of confidence is probably the one which has the closest relation to privacy interests". The author also referred to the Younger Report on Privacy (1972) at 26, "The law on breach of confidence offers the most effective protection of privacy in the whole of our existing law, civil and criminal. The same view is shared by Gurry F Breach of Confidence (Oxford University Press, Clarendon, 1984) at 13 "The function of the action [for breach of confidence] in protecting personal confidences is closely associated with the notion of privacy".
} 
equitable action for breach of confidence has long been recognised as capable of being used to protect privacy. ${ }^{22}$

An action for breach of confidence has, therefore, long been available to a plaintiff whose confidential information has been or threatened to be disclosed to a third party. ${ }^{23}$ However, with the passing of the HRA, the inherent function of breach of confidence in protecting confidential personal information has shifted to a broader protection for privacy of personal information. It has been the means by which courts could restrain the publication of personal information. Privacy authors argue that the equitable action for breach of confidence provides much fuller protection of privacy than other common law principles. $^{24}$

\section{B Traditional breach of confidence action}

In an action for a traditional breach of confidence, there are three important elements as established by Megarry $\mathrm{J}$ in Coco $v$ AN Clark (Engineers) Limited: ${ }^{25}$

First, the information itself...must have the necessary quality of confidence about it. Secondly, that information must have been imparted in circumstances importing an obligation of confidence. Thirdly, there must be an unauthorised use of that information to the detriment of the party communicating it.

\footnotetext{
${ }^{22}$ Campbell, at [43].

${ }^{23}$ For example in Pollard v Photographic Co (1888) 40 Ch D 345, the plaintiff successfully sued the photographer for incorporating her image onto Christmas cards for general sale on the basis of a "gross breach of faith".

${ }^{24}$ Tanya Aplin "The Relationship between Breach of Confidence and 'The Tort of Misuse of Private Iinformation"” (2007) 18(2) King's Law Journal 329; see also Fenwick and Phillipson, above n 22 and Gavin Phillipson "Transforming Breach of Confidence? Towards a Common Law Right of Privacy under the Human Rights Act" (2003) 66 Modern L Rev 726. ${ }^{25}$ [1969] RPC 41 at 47 (Coco). The conditions for a claim for breach of confidence are summarised by Megarry VC in Malone, above n 10.
} 
The elements for the action show that the focus of breach of confidence was the protection of commercial information. The information is not protected if the public interest served by disclosing the information in question outweighs the interest in preserving confidentiality, even though all the elements are satisfied. A claim for breach of confidence can be sustained if the information obtained in the course of a relationship with an obligation of confidence is subsequently published and no public interest exists in that information is being made public. ${ }^{26}$

In order to establish a traditional breach of confidence action, one must first show that the information in question is confidential in the sense that it is available to one person (or a group of people) and not generally available to others, provided that the person or group who possesses it does not intend that it should become available to others. ${ }^{27}$ Personal information is a type of confidential information protected by personal confidences. Confidentiality is thus the basic attribute used to determine whether the information possesses the necessary quality of confidence. In Douglas $v$ Hello Ltd, the Court of Appeal defined "private information" to include information that is personal to the person who possesses it and that person does not intend it to be imparted to the general public. ${ }^{28}$ The nature of the information, or the form in which it is kept, may suffice to make it plain that the information satisfies these criteria. ${ }^{29}$

However, personal information is only capable of being protected by breach of confidence if it has been imparted in circumstances importing an obligation of confidence. In contrast, not all breach of privacy cases result from duty or relationship. Within the scope of the information, personal information is entitled to similar protection because it could have the necessary quality of

\footnotetext{
${ }^{26}$ See Seager v Copydex Ltd [1967] 1 WLR 923.

${ }^{27}$ See Douglas v Hello Ltd [2006] QB 125 (CA).

${ }^{28} \mathrm{At} \mathrm{[55].}$

${ }^{29} \mathrm{At} \mathrm{[83].}$
} 
confidence about it. ${ }^{30}$ The requirement of the quality of confidence was raised in Schering Chemicals v Falkman in which the court found that the test was subjective because widely known facts were still the object of a duty of confidence. $^{31}$

The second element in which confidential information be "imparted in circumstances importing an obligation of confidence" implies that such information must be voluntarily disclosed or communicated by the confider. The existence of a confidential relationship is a key factor in determining whether a breach exists. In the absence of a pre-existing relationship of trust such as that of doctor-patient, lawyer-client or employer-employee from which an obligation of confidence could be inferred, an action for redress by a person whose personal information had been disclosed would fail. Thus, it is necessary to establish a relationship of confider and confidant before an action for a breach of confidence may be sustained. ${ }^{32}$

The relationship of confidence is observed to be the essential feature of the law of confidence. However, the requirement of a pre-existing relationship was largely been done away in Attorney General v Guardian Newspapers Ltd (No 2). ${ }^{33}$ The principle that omits the requirement of a prior confidential relationship was accepted in Earl Spencer $v$ United Kingdom ${ }^{34}$ and was applied in $A v B$ plc. ${ }^{35}$ Lord Woolf CJ formulated the principle: ${ }^{36}$

\footnotetext{
${ }^{30}$ This is evidenced in the case Prince Albert $v$ Strange (1849) ER 1171 where etchings of family life of Prince Albert and Queen Victoria were protected on the basis of breach of trust, confidence or contract. In Argyll v Argyll [1967] Ch 302, breach of confidence was used to protect information communicated within a marriage.

${ }^{31}$ Schering Chemicals v Falkman [1981] 2 All ER 321 (CA).

${ }^{32}$ See Coco, above n 28 . Megarry J's test explained the second requirement at 48 , "if the circumstances are such that any reasonable man standing in the shoes of the recipient of the information would have realised that upon reasonable grounds the information was being given to him in confidence, then this should suffice to impose upon him the equitable obligation of confidence."

${ }^{33}$ [1990] 1 AC 109 (HL) (Spycatcher).

${ }^{34}$ [1998] 25 EHRR CD 105.

${ }^{35}$ [2003] QB 195 (CA) (Av B plc).

${ }^{36}$ At 207, [11] (ix) and (x).
} 
The need for the existence of a confidential relationship should not give rise to problems as to the law because a duty of confidence will arise whenever the party subject to the duty is in a situation where he knows or ought to know that the other person can reasonably expect his privacy to be protected. The difficulty will be as to the relevant facts, bearing in mind that, if there is an intrusion in a situation where a person can reasonably expect his privacy to be respected, that intrusion will be capable of giving rise to liability unless the intrusion can be justified.

The third element requires the claimant to prove that there was unauthorised use of the information and the communicating of it to others was detrimental to the claimant. This element raises no difficulties in circumstances resulting in breach of an individual's privacy because both torts of privacy recognised in the UK and New Zealand concern publication of private information to third parties.

Having discussed the requirements of an action for breach of confidence, the question is does traditional breach of confidence protect privacy? If it does, a breach of privacy could adequately be protected through a breach of confidence action and could be easily followed by Malaysia. However, as discussed in Chapter Three, the existing common law principles including the law of confidence are not capable of providing remedies for breach of privacy.

The Malaysian courts have so far not seen fit to expand the traditional scope of the breach of confidence doctrine. This action continues to be available only where confidential information has been made available in breach of a relationship of confidentiality. Furthermore, the Malaysian courts have not accepted the Spycatcher extension in deciding breach of confidence cases. Their inadequacies require another method of protection than that provided by a traditional breach of confidence action. 
Conceptually, a claim for breach of confidence is quite different from a claim for infringement of privacy since it depends upon the obligation of confidence imposed on both parties. A claim for infringement of privacy on the other hand, focusses on the nature of the information: it would be because the information in question is of a personal or domestic nature, and the person whom it concerned would normally expect it not to be revealed to third parties.

However, there is an overlap between confidence and privacy. Where information of a confidential and personal nature is given or received in circumstances in which an obligation of confidence is imposed, the victim of the infringement of privacy can utilise the law of breach of confidence. ${ }^{37}$ This is illustrated in Stephens $v$ Avery. ${ }^{38}$ In that case, the plaintiff wanted to prevent further publication by the press of information given by a friend about the plaintiff's sexual conduct. She claimed that she had given the information in confidence. However, it was argued that there was no claim in confidence because there was no pre-existing relationship or contract between the parties. While rejecting the approach, Sir Nicolas Browne Wilkinson VC stated that it was not the relationship between the parties that determined whether there was a claim for breach of confidence but rather the acceptance of the information on the basis that it would be kept secret that affected the conscience of the recipient of the information. ${ }^{39}$

He also commented on the relationship between privacy and freedom of information. He found it difficult to draw a line between the aggressive intrusion of sectors of the press into private lives of individual and its ability to obtain and publish information of genuine public interest, as opposed to

\footnotetext{
${ }^{37}$ Arden "The Future Law of Privacy" (1998-1999) 9 King College LJ 1 at 5. ${ }^{38}[1988]$ Ch 449.

${ }^{39}$ At 456.
} 
general public titillation which might be impaired if information obtained in confidence were too widely protected by the law. ${ }^{40}$

Another difference between privacy and confidence is that breach of confidence would cover any kind of confidential information, including commercial information. A claim for infringement of privacy would in general only cover information of a personal nature. Breach of confidence focuses on the need to uphold the obligation of confidence whereas in enforcing a claim for infringement of privacy the court would be concerned with damage to the plaintiff as a result of an unauthorised publication. ${ }^{41}$

Breach of confidence and the tort of privacy serve different purposes. A breach of confidence action is largely (but not wholly) concerned with preserving and engendering respect for relationships of trust and confidence. In the context of personal information, there may be particular kinds of confidential relationships, such as doctor-patient, lawyer-client, or employeremployee that society wants to reinforce. A right to privacy, on the other hand, is concerned with protecting the dignity and autonomy of individuals and providing them with informational control critical to human well-being. ${ }^{42}$

The differences in aim and purpose were made clear when Gurry distinguished a number of ways in which these elements of the traditional action fail to protect disclosure of private information. ${ }^{43}$ According to Gurry, rights under the traditional cause of action operate only against the confidant, and not against the world at large. This means that where private information

\footnotetext{
${ }^{40}$ At 456-457. This issue has also been highlighted in "The Future Law of Privacy" above n 37.

${ }^{41}$ Arden, above n 37 at 6.

${ }^{42}$ See Hosking $v$ Runting [2005] 1 NZLR 1, per Tipping J: It is of the essence of the dignity and personal autonomy and wellbeing of all human being that some aspects of their lives should be able to remain private if they so wish, at [58].

${ }^{43}$ See Tanya Aplin [et al] Gurry on Breach of Confidence: The Protection of Confidential Information ( $2^{\text {nd }}$ ed, Oxford University Press, 2012); see also Francis Gurry Breach of Confidence (Oxford University Press, Clarendon, 1984).
} 
about an individual is gained from a public source, the confider has no rights of action in breach of confidence against that person. The need for an identifiable, pre-existing relationship of trust in the traditional cause of action from which an obligation of confidence could be inferred, has made it nearly impossible for persons whose personal information had been disclosed to have any redress, in the absence of such a relationship. ${ }^{44}$

The above discussion illustrates that the traditional breach of confidence action is not capable of protecting privacy which involves private rather than confidential information. The absence of a prior relationship of trust and confidence between the parties in a privacy action does not sit well with the second requirement established in Coco. The artificiality of distinguishing between information obtained through the abuse of a confidential relationship with similar information obtained in some other way has led the English courts to recasting the traditional breach of confidence action. ${ }^{45}$ As a result, there are now two types of breach of confidence action in English law. ${ }^{46}$

The next Part shows how the shift in determining confidentiality of personal information has taken place. Instead of questioning whether the information is "confidential", the question now is whether the information is "private". The post-HRA cases demonstrate this change and accordingly the altered landscape of privacy protection in English law.

\footnotetext{
${ }^{44}$ Rebecca Taseff "The Protection of Personal Privacy: The Differences between A Privacy Tort and The Action for Breach of Confidence" (2005) 10 Media and Arts Law Review 208 at 211. The author also referred to Gurry, above n 43.

${ }^{45}$ Lord Hoffman in Campbell at [46].

${ }^{46}$ Taseff, above n 44, at 211.
} 


\section{Breach of Confidence Post-HRA}

\section{A The Impact of the HRA 1998 on the Law of Privacy}

This section examines the role of the HRA in providing protection against breach of privacy and how English courts interpret its provisions in order to give effect to cases between private individuals. It has greatly influenced the development of the law of confidence and its relationship to privacy in England. Information no longer needs to be transmitted via a confidential relationship in order to create an obligation of confidentiality.

The HRA 1998 came into force on 2 October 2000 having brought together all Convention rights enforceable in the UK courts. The Act promotes compatibility between English domestic law and European Convention in three main ways: ${ }^{47}$

i) it requires all legislation to be interpreted and given effect as far as possible compatibly with the Convention rights.

ii) it makes it unlawful for a public authority to act incompatibly with the Convention rights and allows for a case to be brought in a UK court or tribunal against the authority if it does so.

iii) UK courts and tribunals must take account of Convention rights in all cases that come before them. The common law must be developed in compatibility with the Convention rights by taking into account of Strasbourg case law.

Under the HRA, the courts or judges have no power to overrule statutes which contravene Convention rights. ${ }^{48}$ By virtue of s 6 , though, courts at all levels are under a duty to do everything possible to interpret legislation in

\footnotetext{
${ }^{47}$ See Department for Constitutional Affairs "A Guide to the Human Rights Act 1998: Third Edition" (2006) <http://www.justice.gov.uk/downloads/human-rights/act-studyguide.pdf>

${ }^{48}$ Section 6 of the HRA 1998.
} 
conformity with Convention rights. In other words, the HRA functions to give further effect in UK law to most of their rights under the European Convention on Human Rights. It affects the way Government and other public authorities deal with individuals and promotes a new culture of rights and responsibilities.

The term "horizontal effect" is used to describe the impact of the Convention rights in legal relations between two private parties. It is distinguished from vertical proceedings brought by an individual to enforce the obligations by the state. The main effect of the HRA is vertical, affecting cases between individuals and state or public authorities rather than disputes between private parties. However, the Act requires all legislation and courts, as far as possible, to give effect compatibly with the Convention rights. This means that the Act has some horizontal effect, allowing the Convention rights to be invoked in proceedings between private parties. ${ }^{49}$

Article 8(1) protects only against interference with privacy by a public authority where it has "vertical effect" between the state and the citizen. After the passage of the HRA 1998 there was much debate as to the extent to which the positive obligation meant that the Convention, via the 1998 Act, had a "horizontal effect" between private persons. Although the equivalent of art 8 has been enacted as part of English law, it is not directly concerned with the protection of privacy against private persons or corporations. It is, by virtue of s 6 of the 1998 Act, a guarantee of privacy against public authorities only. ${ }^{50}$

Section 6(3) defines "public authority" to include "a court or tribunal". Thus, it follows that if the case involved a Convention right, a court must decide in accordance with it, either in a case between private parties or a case against a public authority.

\footnotetext{
${ }^{49}$ See "A Guide to the Human Rights Act 1998: Third Edition", above n 48.

${ }^{50}$ Campbell, at [49].
} 
Indirect horizontal effect means that although a claimant cannot invoke a Convention right directly against another private party, the court regards Convention principles as relevant to the continuing development of the law. ${ }^{51}$ Indirect horizontal effect gained judicial support in Campbell: ${ }^{52}$

The 1998 Act does not create any new cause of action between private persons. But if there is a relevant cause of action applicable, the court as a public authority must act compatibly with both parties' Convention rights.

Although Baroness Hale supported the duty of the court to develop the tort of breach of confidence to protect the Convention rights of privacy and freedom of expression, she stated explicitly that the court was not required to create a new tort of privacy. ${ }^{53}$

When considering any relief in a privacy action, the court acts under s 12 of the HRA. The court must have particular regard to freedom of expression in any case where the relief sought might affect that right. In other words, the effect of s 12 is to impose an obligation on the courts to have exercise a balance between the right of privacy and the right of freedom of expression. Section 12(4) provides:

The court must have particular regard to the importance of the Convention right to freedom of expression and, where the proceeding relate to material which the respondent claims, or which appears to the court, to be journalistic, literary or artistic material (or to conduct connected with such material), to:

\footnotetext{
${ }^{51}$ See Gavin Phillipson "The Human Rights Act, 'Horizontal Effect' and the Common Law: a Bang or a Whimper?" (1999) 62 MLR 824; R Singh "Privacy and the Media after the Human Rights Act" (2000) EHRLR 712; M Hunt "The 'Horizontal Effect' of the Human Rights Act (1998) PL 423; Ivan Hare "Vertically challenged: Private Parties, Privacy and the Human Rights Act" (2001) EHRLR 526.

${ }^{52}$ Campbell, at[132].

${ }^{53}$ See also Alison L Young "Mapping Horizontal Effect" in David Hoffman (ed) The Impact of the UK Human Rights Act on Private Law (Cambridge University Press, UK, 2011).
} 
(a) the extent to which-

(i) the material has, or is about to, become available to the public; or

(ii) it is, or would be, in the public interest for the material to be published;

(b) any relevant privacy code.

Thus, following the enforcement of the HRA 1998, as far as private information is concerned, a breach of confidence action has been the vehicle used by the courts in performing its obligation under the Convention. In this regard, the court should develop the action for breach of confidence in such a way as will give effect to both arts 8 and 10 . The court also must take into account Strasbourg jurisprudence in considering private information issues pursuant to art $8 .{ }^{54}$

Having examined the impact of the HRA on the development of the law of privacy, it is pertinent to discuss the Convention rights relevant for the protection of privacy enshrined in arts 8 and 10 of the ECHR.

\section{B Balancing Competing Convention Rights}

This section discusses the content of the art 8 right to respect for private and family life ${ }^{55}$ and the art 10 right to freedom of expression. ${ }^{56}$ It also explains

\footnotetext{
${ }^{54}$ Douglas v Hello! Ltd (No 3) [2006] QB 125 (CA) (Douglas No 3) at [53].

${ }^{55}$ Article 8 provides "(1) Everyone has the right to respect for his private and family life, his home and his correspondence. (2)There shall be no interference by a public authority with the exercise of this right except such as is in accordance with the law and is necessary in a democratic society in the interest of national security, public safety or the economic wellbeing of the country, for the prevention of disorder or crime, for the protection of health or morals or for the protection of the rights and freedom of others".

${ }^{56}$ Article 10 provides "(1) Everyone has the right to freedom of expression. This right shall include freedom to hold opinions and to receive and impart information and ideas without interference by public authority and regardless of frontiers. This Article shall not prevent States from requiring the licensing of broadcasting, television or cinema enterprises. (2) The exercise of these freedom, since it carries with it duties and responsibilities, may be subject to such formalities, conditions, restrictions or penalties as are prescribed by law and are necessary in a democratic society, in the interest of national security, territorial integrity or public safety, for the prevention of disorder or crime, for the protection of health or morals,
} 
how balancing of these rights is carried out when issues of privacy are involved.

Article 8 protects an individual's privacy. What actually constitutes the scope of private life is broad. When applying the concept, English courts refer to decisions of the European court. Moreham examined the category of private life contained in art 8. According to her, the right is acknowledged to go beyond the "right to privacy, the right to live as privately as one wishes and to be protected from publicity". 57

Lord Nicholls acknowledged the values enshrined in arts 8 and 10 as part of the cause of action for breach of confidence ${ }^{58} \mathrm{He}$ detailed the role of art 8 in connection with privacy and free speech. Art 8(1) recognises the need to respect private and family life. Art 8(2) recognises circumstances in which intrusion into private and family life may be justified. One such intrusion is for the protection of the rights and freedom of others. To safeguard these rights, art 10(1) recognises the importance of freedom of expression but limits the right when protection of the rights of others is justified and makes it necessary for freedom of expression to give way. Lord Nicholls refers to the engagement of both articles as proportionality. ${ }^{59}$ In this regard, art 10 is part of privacy right by virtue of the restrictions provided by art 8(2).

According to Lord Hope, the effect of both provisions is that the right to privacy which lies at the heart of an action for breach of confidence must be balanced with the right of the media to impart information to the public.

for the protection of the reputation of rights of others, for preventing the disclosure of information received in confidence, or for maintaining the authority and impartiality of the judiciary."

${ }^{57}$ NA Moreham "The Right to Respect for Private Life in the European Convention on Human Rights: A Re-examination" (2008) EHRLR Issue 1, 44 at 45 ["The Right to Respect for Private Life"]. The author referred to a number of cases, see Peck v United Kingdom [2003] 36 EHRR 41 at [57]; Niemietz v Germany [1992] 16 EHRR 97 at [29]; Pretty v United Kingdom [2002] 35 EHRR 1 at [61].

${ }^{58}$ Campbell, at [17].

${ }^{59}$ At [20]. 
Similarly, the right of the media to impart information to the public must be balanced against the respect for private life. ${ }^{60}$ In other words, public interest in disclosure must be balanced against the right of the individual to respect for their private life. The test to be applied is whether publication of the material pursues a legitimate aim and whether the benefits achieved by its publication are proportionate to the harm that may be done by the interference with the right to privacy. ${ }^{61}$

However, another standard of proportionality also applies. Baroness Hale stated that: ${ }^{62}$

\begin{abstract}
The application of the proportionality test is more straightforward when only one Convention right is in play: the question then is whether the private right claimed offers sufficient justification for the degree of interference with the fundamental right. It is much less straightforward when two Convention rights are in play, and the proportionality of interfering with one has to be balanced against the proportionality of restricting the other. As each is a fundamental right, there is evidently a "pressing social need" to protect it.
\end{abstract}

The importance of arts 8 and 10 in relation to the development of privacy law in the UK is paramount. The court has a duty to strike a fair balance between the competing rights of the claimant to respect for private life under art 8 and of the defendant to freedom of expression. Although this balancing exercise is not new under English law, ${ }^{63}$ European court decisions must be taken into account when interpreting Convention rights.

\footnotetext{
${ }^{60}$ At [105].

${ }^{61}$ At [113].

${ }^{62}$ At [140].

${ }^{63}$ See Spycatcher, above n 34 .
} 
The two versions of breach of confidence branches, namely the classic Coco or "old fashioned" version and the "new version" are clearly recognised in Douglas ${ }^{64}$ where Lord Nicholls said: ${ }^{65}$

Breach of confidence...now covers two distinct causes of action, protecting two different interests: privacy and secret (confidential) information. It is important to keep these two distinct.

It is essential to examine the "new version" and its impact on the development of the law of privacy. This is discussed in the following section.

\section{Douglas and the New Methodology}

The most vital change to a breach of confidence action in response to the enactment of the HRA was the extension of the requirement of a confidential relationship between parties which is the key element of a confidence action. As discussed in Part II (B), the breach of confidence action has been used to protect confidential relationship but had no comprehensive protection for private information. However, Spycatcher confirmed that need for an initial confidential relationship between the parties no longer applied in a breach of confidence action. This was later reinforced in Douglas, Campbell and Murray. ${ }^{66}$

\section{$1 \quad$ Background}

The first case post-HRA to consider the significance of the Act for breach of confidence was Douglas. The case has changed the question of whether a right to privacy exists in English law to how protection should be provided. In the celebrated case of Michael Douglas and Catherine Zeta-Jones, an

\footnotetext{
${ }^{64}$ Douglas v Hello! Ltd [2007] UKHL 21 (HL).

${ }^{65}$ At [255].

${ }^{66}$ Murray v Express Newspaper Plc [2008] EWCA Civ 446 (CA) (Murray).
} 
agreement was entered between them and $O K$ ! magazine for the exclusive rights of the magazine to take photographs of their wedding and the right to publish the photographs with an accompanying article. The couple had restricted all staff at the wedding and the guests from taking photographs by their signing a confidentiality agreement as well as having security checks around the hotel. However, unauthorised photographs of the wedding were taken and offered for sale a few days afterwards. They were bought by Hello! magazine, a competitor of $O K !$ magazine. The couple and $O K !$ magazine applied for an interim injunction to prevent Hello! from publishing the photographs and it was granted. The defendant appealed.

In the Court of Appeal, the claimant relied upon establishing a cause of action in breach of confidence in order to obtain an interlocutory injunction. However, the injunction was discharged and the court recorded that the case had more to do with privacy than confidentiality. ${ }^{67}$ The issue was whether $\mathrm{Mr}$ Douglas and Ms Zeta Jones had a right to privacy which English law would recognise. ${ }^{68}$

\section{The articulation of the right to privacy}

The important question for this section is to what extent was the development in Douglas dependent on the HRA? The discussion below explains the court's articulation of the right to privacy which is relevant for constitutional development of privacy right in Malaysian law.

Brooke, Sedley and Keene LJJ conducted an analysis of the position by reference to the development of the common law, the doctrine of breach of confidence, its effect upon the enforcement of the HRA 1998, and the right to respect for private life in art 8 of the Convention. It led to the recognition

\footnotetext{
${ }^{67}$ At [164].

${ }^{68}$ At [60].
} 
from the English court that there is a right to privacy in England. Sedley LJ confirmed the birth of a right to privacy: ${ }^{69}$

\begin{abstract}
The court have done what they can, using such legal tools as were to hand, to stop the more outrageous invasions of individual's privacy; but they have felt unable to articulate their measures as a discrete principle of law. Nevertheless, we have reached a point at which it can be said with confidence that the law recognises and will appropriately protect a right of personal privacy.
\end{abstract}

The question was how the right to privacy could be refashioned from common law and equity to be explicitly recognised by the courts because the ingredients of the law of confidence, in reality, contained all that was necessary for the protection of the right to privacy. Sedley LJ expressed the view that articulation of the right in these terms was a small step and one which had been taken obiter by Laws J, in Hellewell $v$ Chief Constable of Derbyshire: ${ }^{70}$

I entertain no doubt that disclosure of a photograph may, in some circumstances, be actionable as a breach of confidence. If someone with a telephoto lens were to take from a distance and with no authority a picture of another engaged in some private act, his subsequent disclosure of the photograph would, in my judgment, as surely amount to a breach of confidence as if he had found or stolen a letter or diary in which the act was recounted and proceeded to publish it. In such a case the law would protect what might reasonably be called a right of privacy, although the name accorded to the cause of action would be breach of confidence.

\footnotetext{
${ }^{69}$ At [110].

${ }^{70}[1995] 1$ WLR 804 at 807.
} 
Sedley LJ's pronouncement on the existence of a right to personal privacy was as a result of the development of common law and equity in response to infringements to privacy and private life. ${ }^{71}$ His analysis of common law led him to the conclusion that Michael Douglas and Catherine Zeta-Jones had, at least, a powerfully arguable case to advance at trial of rights to privacy which should be recognised and protected in appropriate circumstances. His Lordship sought to distinguish the notion of the breach of law of confidence as previously understood, from the right to privacy: ${ }^{72}$

\begin{abstract}
What a concept of privacy does, however, is accord recognition to the fact that the law has to protect not only those people whose trust has been abused but those who simply find themselves subject to an unwanted intrusion into their personal lives. The law no longer needs to construct an artificial relationship of confidentiality between intruder and victim: it can recognise privacy itself as a legal principle drawn from the fundamental value of personal autonomy.
\end{abstract}

In His Lordship's view, to recognise a right to privacy grounded in the equitable doctrine of breach of confidence did little more than say "by way of label" what courts have been saying over the years. ${ }^{73}$ However, recognising a concept of privacy permitted this interest to be protected more directly as an independent legal principle. ${ }^{74}$

Having recognised a right to privacy, Sedley LJ also considered the position of the HRA and stated that if the shift from confidentiality to privacy amounted to more than a modern restatement of the scope of confidence, this was "precisely the kind of incremental change for which the Act is

\footnotetext{
${ }^{71}$ At [111].

${ }^{72}$ Sedley LJ at [126].

${ }^{73}$ At [125].

${ }^{74}$ At [126].
} 
designed". ${ }^{75}$ Moreover, Sedley LJ interpreted s 12(4) as allowing privacy interests to be taken into account. He stated that when a court was considering whether or not to grant relief which might affect the right to freedom of expression, the fact that particular regard must be given to this right, as required by art 12(4), in turn required particular regard of art $8 .{ }^{76}$ This is because art 10 is itself qualified in favour of reputation, the rights of others and the protection of information received in confidence. ${ }^{77}$

On the other hand, Brooke LJ felt it unnecessary for the Court to decide the extent of the right and its basis whether as a new tort or an extension of breach of confidence. His Lordship was clear, however, that "the task of definition and enforcement fell clearly within the judiciary's domain and that the concern to establish and protect a right to privacy was one for which the judiciary had good credentials." ${ }^{, 78}$ It appeared that his confidence in the future protection of a right to privacy stemmed from the positive obligations deemed to flow from the Convention itself. Yet, his optimism was clearly tempered by the difficulty confronting a court in the future with the problem of determining the extent to which a horizontal right of privacy exists as a matter of law. At the end of his analysis, Brooke LJ said: ${ }^{79}$

...where Parliament in this country has been so obviously content to leave the development of the law to the judges, it might seem strange if the absence of art 1 from our national statute relieved the judges from taking into account the positive duties identified by the Court at Strasbourg when they develop the common law. In this judgment, however, I have the luxury of identifying difficult issues. I am not obliged to solve them.

\footnotetext{
${ }^{75}$ At [129].

${ }^{76}$ At [134].

${ }^{77}$ At [133].

${ }^{78}$ At $[88]$.

${ }^{79}$ At [91].
} 
Keene LJ was reluctant to express a definitive view that s 6 could in fact justify the creation of a new cause of action by judicial pronouncement, given certain limitations in the Act. His Lordship's view was that the creation of a new cause of action between private persons and bodies is controversial, as to do so it would appear to circumvent the restrictions on proceedings contained in $\mathrm{s} 7(1)$ of the Act and on remedies in $\mathrm{s} 8(1) .{ }^{80}$

His Lordship preferred an approach of fresh analysis of the common law and equity assisted by the impetus of the interpretative obligation under the HRA $:^{81}$

...it is unnecessary to determine the above issue in these proceedings, where reliance is placed on breach of confidence, an established cause of action, the scope of which may now need to be approached in the light of the obligation on this court arising under s 6(1) of the Act.

Keene LJ further commented on the exemption of a pre-existing confidential relationship between the parties: ${ }^{82}$

The nature of the subject matter or the circumstances of the breach and the defendant's activities may suffice in some instances to give rise to liability for breach of confidence. That approach must now be informed by the jurisprudence of the Convention in respect of art 8 . Whether the resulting liability is described as being for breach of confidence or for breach of a right to privacy may be little more than deciding what label is to be attached to the cause of action, but there would seem to be merit in recognising that the original concept of breach of confidence has in this particular category of cases now developed into something different from the

\footnotetext{
${ }^{80}$ Keene LJ at [166]

${ }^{81}$ At [166].

${ }^{82}$ At [166].
} 
commercial and employment relationships with which confidentiality is mainly concerned.

All three Lord Justices concurred in discharging the injunction against Hello! having regard to the competing considerations relating to prior restraint of such publication. There was a strong balance of convenience argument for such discharge because $O K$ ! magazine could more readily be compensated in damages for any breach which was subsequently established at trial, whereas Hello! would suffer very serious consequences difficult to assess financially if it were not permitted to publish its printed edition of the magazine. But it is also significant that the Court of Appeal did not feel hindered in carrying out their own balancing exercise as between the privacy rights of Michael Douglas and Catherine Zeta-Jones and the freedom of expression rights of Hello! magazine.

Significantly, the decision in Douglas confirmed the development of a right to privacy and introduced a new methodology extended from the law of breach of confidence. It also applied the HRA and highlighted the horizontal issue in relation to it. Though the analysis was based on an interlocutory decision, it had canvassed issues that had not been dealt with before. The reluctance of both Brooke and Keene LJJ to accept the creation of a full-fledged right to privacy meant that the issue remained to be determined by subsequent proceedings. ${ }^{83}$

The judges' analysis in Douglas, in particular that of Sedley and Keene LJJ revealed that the establishment of a right to privacy developed under the common law was stimulated by the duty to act compatibly with the Convention's right. The combination of the common law, equity and the obligations under the HRA ensure that development of the right to privacy

\footnotetext{
${ }^{83}$ See Philip Plowden "Right to Privacy - Michael Douglas, Catherine Zeta-Jones, Northen and Shell plc v Hello Ltd." (2001) 6 Journal of Civil Liberties 57, at 72.
} 
does not proceed in a vacuum and without regard to the high value accorded to art 10

Shortly after Douglas, the case of Venables and Thompson $v$ Newsgroup Newspapers and Associated Newspapers Ltd ${ }^{84}$ brought into question again the status of the right to privacy in English law. In that case, two children who had been convicted of the murder in 1993, of James Bulger, a two-year old boy, brought an action seeking continuation of injunctions preventing publication of further information about them. These injunctions had previously been granted under s 39 of the Children and Young Persons Act 1933. The claimant sought effective continuation of the injunctions relating to publication of their identities, appearances, location and history in the secure units, in light of their eighteenth birthdays and their imminent release from secure units.

The injunction was granted against the publication of information about the identity of the two boys. Dame Elizabeth Butler-Sloss P said: ${ }^{85}$

The duty of confidence may arise in equity independently of a transaction between the parties. In this case it would be a duty placed upon the media. A duty of confidence does already arise when confidential information comes to the knowledge of the media, in circumstances in which the media have notice of its confidentiality...The issue is whether the information leading to disclosure of the claimants' identity and location comes within the confidentiality brackets...In my judgment, the court does have the jurisdiction, in exceptional cases, to extend the protection of confidentiality of information, even to impose restriction on press, where not to do so would be likely to lead to serious physical injury, or to death, of the person seeking that

\footnotetext{
${ }_{85}^{84}[2001] 2$ WLR 1038; [2001] 1 All ER 908.

${ }^{85}$ At 933 .
} 
confidentiality, and there is no other way to protect the applicants other than by seeking relief from the court.

Again in $A v B p l c^{86}$ the court accepted that a pre-existing confidential relationship between the parties was no longer necessary in an extended breach of confidence action. Lord Woolf stated that the range of situations in which protection could be provided was extensive and, therefore, the necessary relationship could be expressly created. Its existence could also be inferred from the facts and circumstances between the parties at the time of the threatened or actual breach of alleged duty of confidence. ${ }^{87}$

Douglas and subsequent cases have, therefore, confirmed that an invasion of privacy could be protected through the extended version of breach of confidence action in which there was no longer a need to establish that a relationship of confidence existed. Although there was some suggestion that this step could have been taken without the influence of the HRA, ${ }^{88}$ the Act was ultimately crucial in transforming the landscape of privacy protection in English law into a new category of privacy breach. This finally led the House of Lords in Campbell to accept that breach of confidence was the appropriate means of protecting privacy.

Further, debate about whether the privacy action to have emerged from within breach of confidence and whether invasion of privacy is a tort or an equitable action has been settled in Vidal Hall and Ors $v$ Google Inc ${ }^{89}$ where Tugendhat $\mathrm{J}$ confirmed that misuse of private information is now a tort. The judge concluded that there was a distinct "tort of misuse of private information" which was a tort within the meaning of the Civil Procedure Rules.

\footnotetext{
${ }^{86}$ [2003] QB 195.

${ }^{87}$ At 207 , [ix].

${ }^{88}$ See in particular, judgment given by Sedley LJ in Douglas.

${ }^{89}$ [2014] EWHC 13 (QB).
} 


\section{Privacy Post-HRA}

This part examines the tort of misuse of private information effected by the utilisation of breach of confidence action and the formulation of the privacy action in Campbell. Although it is not possible for Malaysia to shift from breach of confidence action to an action of misuse of private information in the same way, now that there is a privacy action and its contents and substance provide some interesting points for Malaysia.

\section{A The Tort of Misuse of Private Information}

In any claim based on the misuse of private information, two conditions need to be satisfied: the nature of the information and the balancing of arts 8 and 10 which favours the protection of the claimant's right to privacy. For the first condition, the starting point is to consider whether the information is sufficiently private in nature to engage art 8 of the Convention. Whether information is "private" depends on whether the claimant had a reasonable expectation that the information would remain private. The reasonableness of the expectation should be assessed from the perspective of a reasonable person of ordinary sensibilities placed in the same position as the claimant and faced with the same publicity. ${ }^{90}$

As for the second, a balance must be struck between the competing rights of privacy and freedom of expression. The important question is whether the publication of private information complained about by a claimant forms part of a legitimate public interest which outweighs the claimant's right to privacy.

\footnotetext{
${ }^{90}$ At [99].
} 
Campbell $v$ MGN Ltd created a new privacy tort in English law referred to as "misuse of private information". ${ }^{91}$ In that case, a well-known fashion model sought damages for the publication of an article disclosing details of her drug addiction including the time, place and frequency of treatment she was receiving, and of a photograph showing her outside one of her therapy meetings. Although she accepted that the newspaper was entitled to correct public statements she had made about managing to stay away from drugs, Campbell claimed that publication of the photograph and the additional details interfered with her right to privacy. All five members of the House agreed that there was a tort protecting against the misuse of private information, although only a majority held that the action succeeded on the facts of the case. ${ }^{92}$

The majority ruled that publication of the details of the photographs and information relating to the treatment Miss Campbell was receiving for drug addiction constituted a considerable intrusion into her private affairs. The press had published more private information than was necessary to pursue the legitimate aim of correcting incorrect statements made by Miss Campbell regarding her use of drugs. In doing so, the press had therefore, overstepped the margin of appreciation, to which it was entitled under art 10 of the ECHR, so as to have disproportionately infringed Miss Campbell's rights under art $8 .^{93}$

Campbell is not only important for recognising a tort of misuse of private information, it also resolved many issues of importance in the development of the law of privacy, such as the use of breach of confidence action to protect privacy, how the court formulates the privacy action, the employment of the

\footnotetext{
${ }^{91}$ At 458 .

${ }^{92}$ The minority (Lord Nicholls and Lord Hoffman) held that the publication of the photographs and the extra details were within the margin of editorial judgment and something for which appropriate latitude should be allowed.

${ }^{93}$ The majority decision by Lord Hope, at [124-125], Baroness Hale, at [154-155], and Lord Carswell, at [170-171].
} 
reasonable expectation of privacy test and the balancing exercise between arts 8 and 10. These matters are discussed in the following sections.

\section{$1 \quad$ Utilisation of breach of confidence action}

The principles formulated by Lord Nicholls are the basis for the development of the right to privacy. His Lordship acknowledged that the freedoms in arts 8 and 10 of the Convention are vitally important rights which lie at the heart of liberty in a modern state and that neither has precedence over the other. ${ }^{94}$ Although the origin of the cause of action relied upon is breach of confidence, the more natural description of the position today is that such information is private and the essence of the tort is better encapsulated now as misuse of private information since information about an individual's private life would not, in ordinary usage, be called "confidential". ${ }^{95}$

His Lordship added that by virtue of the HRA 1998, the value enshrined in arts 8 and 10 is now part of the cause of action and should be treated as of general application and as being as applicable to disputes between individuals as to disputes between individuals and a public authority. ${ }^{96}$

The minority in Campbell expressly acknowledged that the concepts of privacy and confidence have merged in cases involving the disclosure of personal information. Lord Hoffman said that development of the breach of confidence action meant that there: ${ }^{97}$

has been a shift in the centre of gravity of the action for breach of confidence when it is used as a remedy for the unjustified publication of personal information... Instead of the cause of

\footnotetext{
${ }^{94}$ Campbell at [12].

${ }^{95}$ At [14].

${ }^{96}$ At [17].

${ }^{97}$ Campbell at [51].
} 
action being based upon the duty of good faith applicable to confidential personal information and trade secret alike, it focuses upon the protection of human autonomy and dignity the right to control the dissemination of information about one's private life and the right to the esteem and respect of other people.

His Lordship further argued for the use of breach of confidence action for privacy action and suggested the use of the phrase "misuse of private information" to avoid confusion in the future: ${ }^{98}$

The continuing use of the phrase "duty of confidence" and the description of the information as "confidential" is not altogether comfortable. Information about an individual's private life would not, in ordinary usage, be called "confidential". The more natural description today is that such information is private. The essence of the tort is better encapsulated now as misuse of private information.

In acknowledging a new claim for wrongful publication of private information as deriving from an equitable doctrine of breach of confidence, Lord Nicholls declared: ${ }^{99}$

In the case of individuals this tort, however labelled, affords respect for one aspect of an individual's privacy. This is the value underlying this cause of action. An individual's privacy can be invaded in ways not involving publication of information. Stripsearches are an example. The extent to which the common law as developed thus far in this country protects other forms of invasions of privacy is not a matter arising in the present case. It does not arise because, although pleaded more widely, Miss Campbell's

\footnotetext{
${ }^{98}$ At [14].

${ }^{99}$ At [15].
} 
common law claim was throughout presented in court exclusively on the basis of breach of confidence, that is, the wrongful publication by the "Mirror" of private information.

The judgment provided an impetus towards protection of private information in English law. The central issue in Campbell is on the type of information disclosed: whether it can be regarded as private or otherwise. The case set up the tests for determining when information is regarded as private in nature. In order to successfully claim under the new tort, the claimant had to show that she had a reasonable expectation of privacy regarding the facts that were published. This test has prevailed in the subsequent case law. The alternative approaches employ the test of "highly offensive to a reasonable person or ordinary sensibilities" and the "obviously private" test. ${ }^{100}$

\section{The formulation of the privacy action.}

The most important question in Campbell was how the court formulated the privacy action. There are two versions of the test adopted in determining privacy action. The simple one adopted by Lord Nicholls is the test of reasonable expectation of privacy - whether the claimant has a reasonable expectation of privacy in respect of the information disclosed. The second is the "highly offensive to a reasonable person of ordinary sensibilities" test put forward by Lord Hope.

\section{(a) Reasonable expectation of privacy test}

Lord Nicholls was the main proponent of the reasonable expectation test in Campbell. His approach of the reasonable expectation of privacy test was:

\footnotetext{
${ }^{100}$ See Moreham "Privacy in the common law", above ch 2 n 89, at 630-633 for a discussion of the three tests that emerged from Campbell. See also Lord Neuberger "Privacy in the 21 st Century" (2012) http://www.supremecourt.gov.uk/docs/speech-121128.pdf, at 19.
} 
In deciding what was the ambit of an individual's "private life" in particular circumstances courts need to be on guard against using as a touchstone a test which brings into account considerations which should more properly be considered at the later stage of proportionality. Essentially the touchstone of private life is whether in respect of the disclosed facts the person in question had a reasonable expectation of privacy.

Baroness Hale was of the view that an objective reasonable expectation test was simpler and clearer than the test sometimes quoted from the judgment of Gleeson CJ in the High Court of Australia. ${ }^{101}$ The question to be asked was whether the defendant knew or ought to have known that the claimant had a reasonable expectation of privacy. The judge added: ${ }^{102}$

It should be emphasised that the "reasonable expectation of privacy" is a threshold test which brings the balancing exercise into play. It is not the end of the story. Once the information is identified as "private" in this way, the court must balance the claimant's interest in keeping the information private against the countervailing interest of the recipient in publishing it. Very often, it can be expected that the countervailing rights of the recipient will prevail.

\section{(b) Highly offensive to a "reasonable person of ordinary sensibilities" test}

Lord Hope was of the view that, in determining a case of wrongful publication of private information, the principle was whether the information disclosed was private and not public. It was an objective question and His Lordship emphasised that the reasonable expectation to be considered was not that of the reader in general, but of the person affected by the publicity. If the

\footnotetext{
${ }^{101}$ Campbell, at [135].

${ }^{102}$ Campbell, at [137].
} 
information is not obviously private, the question to be asked is what a reasonable person of ordinary sensibilities would feel if placed in the same position as the claimant and faced with the same situation. ${ }^{103}$

However, if the information is "obviously private", the test of highly offensive is not relevant because the person to whom the information relates can reasonably expect their privacy to be respected. His Lordship said that the test was not needed where the information could easily be identified as private. ${ }^{104}$

Lord Hope's formulation of the highly offensive test was supported by the socalled Gleeson test. In Australian Broadcasting Corporation v Lenah Game Meats Pty $L t d^{105}$ Gleeson CJ differentiated between "public" and "private" information. He held that information relating to health, personal relationships, and financial status are easily identified as private as are other kinds of activity that a reasonable person would want to be unobserved. Thus, the test of what is highly offensive to a reasonable person of ordinary sensibilities is useful for determining what is private. ${ }^{106}$

A privacy action, therefore, according to Lord Hope concerns the nature of the information before an appropriate test may be applied to determine reasonable expectation of privacy. The test of "highly offensive" is employed in situations where the information disclosed is of a private nature that the claimant does not want made public.

\section{Rejection of the "highly offensive element"}

The test of "highly offensive to a reasonable person of ordinary sensibilities" is similar to that employed by the New Zealand Court of Appeal in Hosking $v$

\footnotetext{
${ }^{103}$ At [99].

${ }^{104}$ At [96].

${ }^{105}$ [2001] 208 CLR 199.

${ }^{106}$ At [42].
} 
Runting. ${ }^{107}$ The difference lies only in the formulation of the question. In Campbell, Lord Hope suggested that the question to be asked is what a reasonable person of ordinary sensibilities would feel if he or she were placed in the same position as the plaintiff and faced the same publicity. ${ }^{108}$ The same test in New Zealand operates on the question of whether publication of photographs or facts would be offensive to the ordinary person.

However, Lord Nicholls advocated caution when using "the highly offensive" test: ${ }^{109}$

This particular formulation should be used with care, for two reasons. First, the "highly offensive" phrase is suggestive of a stricter test of private information than a reasonable expectation of privacy. Second, the "highly offensive" formulation can all too easily bring into account, when deciding whether the disclosed information was private, considerations which go more properly to issues of proportionality; for instance, the degree of intrusion into private life, and the extent to which publication was a matter of proper public concern. This could be a recipe for confusion.

Although Baroness Hale did not expressly reject the "highly offensive" test, she preferred the reasonable expectation of privacy test. She was certain that the Gleeson test was not the only test of determining such information, but she was referring to the sensibilities of a reasonable person placed in the situation of the claimant, rather than to the recipient of the information. ${ }^{110}$

It is submitted that the "highly offensive" test should not be part of the methodology when determining the private character of the information because a claimant in a privacy action is not really offended with the publication of the information, rather "embarrassed" or "humiliated" as a

\footnotetext{
${ }^{107}[2005] 1$ NZLR 1.

${ }^{108}$ Campbell, at [99].

${ }^{109}$ At [22].

${ }^{110}$ At [136].
} 
result of the breach. ${ }^{11}$ The facts that are "truly humiliating and distressful"112 are not necessarily offensive because there are many instances of breach of privacy that has nothing to do with offensiveness. To illustrate, to publish facts about B who suffered from syphilis is not offensive but is very humiliating, as a result of which $\mathrm{B}$ would be avoided by those who have knowledge about the facts.

With the rejection in Campbell, subsequent cases have made it clear that the test in breach of privacy actions is whether the plaintiff had a reasonable expectation of privacy. As a result, there is now in English law a law protecting wrongful publication of private information. Since Campbell, the courts have gone on to give further direct horizontal effect to the right to privacy, embracing the guidance of the ECtHR's von Hannover ${ }^{113}$ ruling and expanding the range of situations in which relief is given for interference with an individual's privacy.

\section{B The Development of Privacy Actions since Campbell}

Campbell confirmed that an action for breach of confidence is capable of providing extensive protection to privacy. Confidential information has been extended to protect private information in the absence of a confidential relationship.

The relationship between "traditional" breach of confidence and protection of privacy was also dealt in Associated Newspapers Ltd $v$ HRH Prince of Wales. ${ }^{114}$ In that case, the Prince brought an action for breach of confidence

\footnotetext{
${ }^{111}$ Moreham "Privacy in the common law" above ch 2 n 89, at 645-646. The author argued that the effect of the breach of privacy is best described as "humiliation" or "distress"; see also Moreham "Why is Privacy Important?", above ch 2 n 9, at 244-245.

${ }^{112}$ Hosking, at 126].

${ }^{113}$ von Hannover [2005] 40 EHRR 1.

${ }^{114}$ [2006] EWCA Civ 1776. See also Lord Neuberger, above n 100, at 20-21.
} 
and copyright infringement in respect of articles published by the appellant in the Mail on Sunday which included extracts from his journals. The journal contained his impressions of an official visit to Hong Kong in 1997. The issue was whether the journal containing his personal views and impressions was private.

The Court of Appeal held that the disclosure by the employee was in breach of an express contractual duty of confidentiality and in breach of a wellrecognised relationship of confidence, and that the newspaper knew that the disclosure of the journal to them was made in breach of confidence. ${ }^{115}$ The court concluded that the judge was correct to hold that the Prince had an unanswerable claim for breach of privacy, and that both the nature of the information and the relationship of confidence under which it was received weighed heavily in favour of the Prince. ${ }^{116}$

However, in Lord Browne of Madingley v Associated Newspaper Ltd ${ }^{117}$ Lord Browne sought to enjoin, on grounds of breach of confidence, publication by the Mail On Sunday of information and allegations of a homosexual relationship he had with a Mr Chevalier. The court held: ${ }^{118}$

The first question under art 8 is whether in respect of the disclosed facts the claimant has a reasonable expectation of privacy in the particular circumstances of the case. That is the relevant question: whether there was a previous confidential relationship between the parties or not.

\footnotetext{
${ }^{115}$ Lord Phillips, at [28].

${ }^{116}$ At [71].

${ }^{117}$ [2008] QB 103 (CA) (Lord Browne).

${ }^{118}$ At [24].
} 
The case showed that in determining whether the claimant has a reasonable expectation of privacy in respect of the information disclosed, the nature of the relationship between parties is of considerable potential importance. ${ }^{119}$

In McKennitt $v$ Ash ${ }^{120}$ Loreena McKennitt brought an action for invasion of privacy against Ms Ash, who had once been a close friend and associate. The first defendant published a book which contained information of the claimant's personal and sexual relationships. At first instance, Eady J held that the claimant had a reasonable expectation of privacy, such as to engage art 8 and this was not outweighed by the art 10 rights of the first defendant. A declaration and an injunction were granted to restrict further publication of infringing passages of the book along with damages of $£ 5,000$ in respect of the claimant's hurt feelings and distress. On appeal, the court upheld the claim and granted an injunction preventing further publication of a significant part of the work on the grounds that it constituted private information under art 8 . The court further held that the claimant's right under art 8 outweighed the defendant's right to freedom of expression under art 10.

McKennitt was a significant case in which the court held that it was necessary to have regard to the ECtHR case of von Hannover when deciding postCampbell privacy cases. This was because the Court of Appeal in A v B plc had not ruled definitively on the content and application of art 10 but instead addressed the balancing exercise effectively in the former English domestic terms of breach of confidence. ${ }^{121}$

Buxton LJ's summary is very helpful in illustrating the position of the law of privacy post-Campbell. First, His Lordship confirmed that there is no English domestic law of invasion of privacy. Secondly, in developing a right to protect

\footnotetext{
${ }^{119}$ At [26].

${ }^{120}$ [2008] QB 73 (CA) (McKennitt). See also Lord Neuberger, above n 100, at 20-21.

${ }^{121}$ At [63].
} 
private information, including the implementation in the English courts of arts 8 and 10 of the ECHR, as adopted by HRA 1998, the English courts have had to proceed through the tort of breach of confidence, into which the jurisprudence of arts 8 and 10 has been "shoehorned". Thirdly, that a feeling of discomfort arose from an action for breach of confidence being employed where there was no such pre-existing relationship between the parties, but that "confidence" arose from the defendant's having acquired by unlawful or surreptitious means information that he should have known he was not free to use. $^{122}$

McKennitt's approach in a case of wrongful publication of private information is two-fold. The requirements of the action are first, the nature of the action in which the recipient's perception of its confidential nature imposes an obligation on him. ${ }^{123}$ Second, the nature of the relationship between the claimant and the defendant gives rise to an expectation of confidence. ${ }^{124}$ Thus, in determining whether there has been a breach of confidence or misuse of private information the court must ask two questions: (i) Is there a reasonable expectation of privacy or in other words is art 8 is engaged? and (ii) If there is, does the balance between privacy and freedom of expression favour the individual's privacy or is it in favour of publication? ${ }^{125}$ In other words, the threshold test is whether the claimant has a reasonable expectation of privacy, as formulated in Campbell is applied.

Another dimension of Campbell can be seen in Murray. ${ }^{126}$ An action was brought on behalf of David Murray, JK Rowling's infant son, for breach of confidence and David's right to privacy in relation to the publication of a photograph of him as a toddler being pushed in a buggy that showed his face in profile, his clothes, his size, the style and colour of his hair and the colour

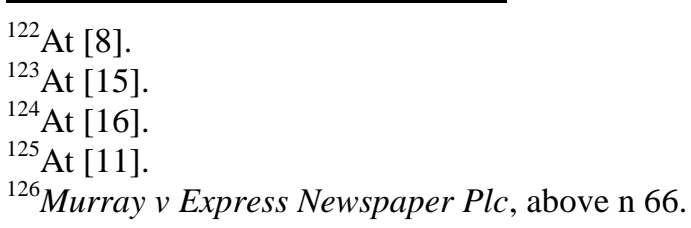


of his skin. The Murrays did not consent to the publication of the photographs and sought an injunction to restrain further publication and any similar taken by Big Pictures. They also claimed damages or an account of profit for breach of confidence, infringement of David's right to privacy and misuse of private information resulting from taking, recording, holding and publishing of the photograph.

The issue was whether David, who is not a public figure but the child of one, is entitled to protection from being photographed, even if the photograph shows nothing embarrassing or unpleasant. The Court of Appeal granted the appeal and found that the child arguably had a reasonable expectation of privacy in relation to the publication of the photograph, notwithstanding his mother's fame and the fact that the picture merely showed him and his parents in a public street.

In Murray, the court said that the question of whether there is a reasonable expectation of privacy is a broad one and suggested that all relevant circumstances of the case be considered: ${ }^{127}$

They include the attributes of the claimant, the nature of the activity in which the claimant was engaged, the place at which it was happening, the nature and purpose of the intrusion, the absence of consent and whether it was known or could be inferred, the effect on the claimant and the circumstances in which and the purposes for which the information came into the hands of the publisher.

The test suggested in Murray requires consideration of all circumstances surrounding the facts of the case before a breach can be established.

${ }^{127}$ At [36]. 
Guidelines will make it easier for the court to ascertain whether a claimant has a reasonable expectation of privacy in the circumstances of a case.

Anthony Clarke MR, however, noted that, the "highly offensive test" was rejected as being stricter than Lord Nicholls's "reasonable expectation of privacy": ${ }^{128}$

\begin{abstract}
It seems to us, therefore that, in so far as it is or may be relevant to consider whether publication of information or matter was "highly offensive", it is relevant to consider it in the context, not of whether art 8 is engaged, but of the issues relevant to proportionality, that is to the balance to be struck between art 8 and art 10.
\end{abstract}

The Court of Appeal's decision in Murray confirms that English privacy law is now in line with ECtHR jurisprudence: that the jurisprudence of the ECtHR, past and future, is binding on English courts when assessing privacy claims and other related Convention rights.

\title{
C Protection against Intrusion
}

The development of the tort of misuse of private information has ensured effective protection of private information. What remains is whether protection could be extended to cover other aspects of privacy interests, namely those of physical privacy or bodily intrusion.

The House of Lords in Wainwright declined to recognise a general right to privacy which would extend to physical privacy interferences not involving the dissemination of information. However, a good observation was made by Lord Keith in Spycatcher when His Lordship said that "...breach of

${ }^{128}$ At [26]. 
confidence involves no more than an invasion of privacy." In a similar vein, Lord Nicholls also predicted that a comprehensive principle for the protection of privacy would exist in the near future though he did not decide whether a right of privacy existed in the case before him. ${ }^{129}$

Apart from that, it is submitted that the most effective legislative protection against privacy interference by intrusion is conferred by the Protection from Harassment Act 1997 (PFHA). ${ }^{130}$ Though "harassment" is not defined in the Act, it potentially covers a wide range of actions including oppressive and unreasonable conduct that cause distress, annoyance and threat.

However, the Act is primarily concerned with providing protection against media intrusion such as unwanted photography, observation, following, telephoning and obtaining access to another's home and property. To constitute harassment within the meaning of the Act, the conduct must have been: ${ }^{131}$

(a) Occurring on at least two occasion

(b) Targeted at the claimant

(c) Calculated in an objective sense to cause distress and

(d) Objectively judged to be oppressive and unreasonable

It is thus clear that in order to bring an action under the Act the action or an act of harassment must occur at least. ${ }^{132}$

If physical privacy is protected by common law principle, the tort of harassment provides some measure of protection for a person's privacy. In

\footnotetext{
${ }^{129} R v$ Khan [1997] AC 558.

${ }^{130}$ Hipgrave $v$ Jones [2004] EWHC 2901 (QB), at [21], Tugendhat J has expressly recognised that the Act protects privacy and that regard should be had to art 8 when interpreting it.

${ }^{131}$ Refer Green v DB Group Services (UK) Ltd [200] EWHC 1898 (CA) as discussed by Moreham "Protection against Intrusion" in Law of Privacy and the Media, above ch 4, n 84, at 431 .

${ }^{132}$ Section 7(3) PFHA.
} 
Khoransandjian $v$ Bush, ${ }^{133}$ the majority in the Court of Appeal upheld an injunction granted to restrain the defendant from inter alia, "harassing, pestering or communicating with" the plaintiff. The harassment and pestering by the defendant, who could not accept that the plaintiff wished end their friendship, took the form of telephone calls to the plaintiff's parents' home. The plaintiff, not having any proprietary interest in her parents' home, could not sustain a claim under the tort of nuisance which originated to protect a person's right to enjoy his property. The judges justified the granting of the injunction on the basis that English law had developed to recognise a tort of harassment.

Apart from the harassment tort, the principle of Wilkinson $v$ Downton ${ }^{134}$ would to a certain extent be applicable in protecting against physical intrusion. In that case, Wright $\mathrm{J}$ observed that since there was no physical touching, there could be no grounds for a claim in battery, and as the plaintiff did not apprehend any immediate physical violence, no claim would exist in common law assault. The judge held that there was a valid claim for the intentional infliction of mental shock. However, the principle of Wilkinson $v$ Downton requires an intention to inflict physical injury including psychiatric harm, whereas physical privacy can be intruded upon although no harm is involved; for example, in situations of unwanted touching by a stranger.

\section{Remedies}

\section{$1 \quad$ Injunctions}

Injunctions have been a very popular remedy in breach of privacy cases, and in fact the only effective remedy, especially in cases concerning publication of

\footnotetext{
${ }^{133}$ [1993] 3 All ER 669.

${ }^{134}[1897] 2$ QB 57.
} 
sensitive personal information or photographs. ${ }^{135}$ An interim injunction is normally obtained to prevent information from being published at the very moment before it is disclosed. $A v B$ plc has laid down the principles to be taken into account when determining application for interim injunctions: ${ }^{136}$

The application for interim injunction have now to be considered in the context of art 8 and 10 of the Convention...Actions for breach of confidence are usually brought at short notice and are followed by an immediate application for an interim injunction...If an interim injunction is to be granted it is essential that it is granted promptly because otherwise the newspaper will be published and then, from the claimant's point of view, the damage will have been done.

The granting of an interim injunction is a matter of the judge's discretion which is exercised in accordance with well-established principles, for example, it is likely that an injunction would be granted after a substantive hearing and would determine the outcome of the entire proceedings. ${ }^{137}$ It follows that the fact that, if the injunction is not granted the claimant may be deprived of their only remedy, is required to be weighed against the defendant's right of freedom of expression. ${ }^{138}$ Once art 10 is engaged, s 12 of the HRA comes into play, in particular s 12(4) which requires the court to have particular regard to the importance of the right to freedom of expression, and to take into account any relevant privacy code.

Thus, $A v B$ plc principles pointed out above are vital in assisting the court to balance between both Convention rights when hearing an application for

\footnotetext{
${ }^{135}$ Gavin Phillipson "Max Moslley goes to Strasbourg: Article 8, Claimant Notification and Interim Injunction" (2009) 1 Journal of Media Law 73, at 75 and 81.

${ }^{136} A$ v B plc, at [4]-[7].

${ }^{137}$ At [11] (i).

${ }^{138}$ At [11] (ii).
} 
injunction. If the balance does not point clearly in either direction then interim relief should be refused. ${ }^{139}$ Lord Woolf CJ explained that: ${ }^{140}$

There is a tension between the two articles which requires the court to hold the balance between the conflicting interests they are designed to protect. This is not an easy task but it can be achieved by the courts if, when holding the balance, they attach proper weight to the important rights both articles are designed to protect. Each article is qualified expressly in a way which allows the interests under the other article to be taken into account.

In the final appeal of Douglas $v$ Hello! ${ }^{141}$ the Court of Appeal granted an interim injunction having found that the Douglases had a virtually unanswerable case that their privacy was infringed: ${ }^{142}$

Only by grant of an interlocutory injunction could the Douglases' rights have been satisfactorily protected. Further, the interests of Hello! at the interlocutory stage, which were essentially only financial, could have been protected by an appropriate undertaking in damages by the Douglases.

Eady $\mathbf{J}$ in Mosley $v$ News Group Newspapers Ltd also acknowledged the effectiveness of injunction as an adequate remedy in a privacy action. The judge said: ${ }^{143}$

...it has to be accepted that an infringement of privacy cannot ever be effectively compensated by a monetary award. Judges cannot achieve what is, in the nature of things, impossible. That

\footnotetext{
${ }^{139}$ At [12]

${ }^{140}$ At [6].

${ }^{141}$ [2006] QB 125 (Douglas No 3).

${ }^{142}$ At [259].

${ }^{143}$ [2008] EMLR $679(\mathrm{QB})$, at 684 (Mosley).
} 
unpalatable fact cannot be mitigated by simply adding a few noughts to the number first thought of...

\section{Damages}

Damages also have been awarded in infringement of privacy actions, but in a relatively small number of cases. In Mosley the court stated that damages for infringement of art 8 could include damages for distress, hurt feelings and loss of dignity. Although the court submitted that an infringement of privacy could not ever be effectively compensated by a monetary compensation, an award of $£ 60,000$ was awarded to Mosley: ${ }^{144}$

\footnotetext{
Once privacy had been infringed, the damage was done and the embarrassment was only augmented by pursuing a court action. The Court had to pick a figure which marked the fact that an unlawful intrusion had taken place, while affording some degree of comfort to the injured party. The figure selected ought not to be such that it could be interpreted as minimising the scale of the wrong done.
}

In Douglas No 3 for example, the court said that the $£ 14,600$ damages awarded was relatively small compared to the legal costs involved. However, the court explained that the categorisation of the sum as "relatively small" was not intended to indicate that the level of damages should have been greater, but to describe that damages in that sum could not fairly be regarded as an adequate remedy. By considering the nature of the injury that the Douglases suffered, that is mental distress, a modest sum by way of damages does not represent an adequate remedy. ${ }^{145}$

\footnotetext{
${ }^{144}$ At 684 .

${ }^{145}$ Douglas No 3, at [255]-[256].
} 
Similarly, Eady $\mathrm{J}$ in McKennitt $v$ Ash ${ }^{146}$ awarded Ms McKennitt a relatively modest $£ 5,000$ for hurt feelings and distress. Ms Campbell was also entitled to the small amount of $£ 2,500$ as general damages for distress and injury to feelings and which were described by Morland $\mathrm{J}$ as "damages on a modest scale". ${ }^{147}$

In relation to an award of damages in a claim for infringement of privacy, it is essential to highlight that exemplary damages are not available since no authority exists to justify such an extension and because it is said a claim would fail the test of necessity and proportionality. ${ }^{148}$

\section{Conclusion}

It is now settled under English law that the means by which privacy interests are protected is through the extension of the law on breach of confidence. The passing of the HRA which gives effect to the Convention rights has altered the English courts' approach towards privacy. In Campbell the House of Lords confirmed that the development of the law of confidence to provide a remedy for invasions of personal privacy had established a new cause of action, clearly distinct from traditional breach of confidence, which is now better described as "misuse of private information". The new cause of action takes a different view of the underlying value which the law of confidence protects.

Although the introduction of a privacy tort has not been the mechanism for protecting privacy in English law, the courts have considerably interpreted and developed the breach of confidence action to remedy their refusal to recognise the action. The formulation of appropriate tests in determining liability in privacy has greatly developed the law to the extent that an

\footnotetext{
${ }^{146}$ [2005] EWHC 3003 (QB), at [162].

${ }^{147}$ Campbell v MGN Ltd [2002] EWHC 499 (QB), at [140].

${ }^{148}$ Mosley, at [197].
} 
individual whose privacy has been invaded can claim a remedy to protect his privacy. The reasonable expectation of privacy test is a well-established test in deciding whether art 8 is engaged in relation to the information.

As mentioned at the beginning of this chapter, the experience of the English courts in developing and recognising the tort of misuse of private information is useful for Malaysia in its effort to deal with privacy problems and provide adequate remedies for the breach. It is suggested, in particular, that Malaysia should use features of the English tort such as the test of reasonable expectation of privacy, and the public interest defence when developing its own privacy protection. As will be seen in Chapter Seven, these elements form a part of the proposed Malaysian Privacy Bill. It will also be recommended that Malaysian privacy law adopt popular remedies such as injunction and damages which are widely granted in England. Other remedies like declaration, account of profits, declaration order and apology are among other remedies provided under the Bill. The adoption of rules and principles from English law will certainly have implications for the future development of the law and will influence the courts' approach to the kind of information entitled to protection, the extent and form of publication which attracts a remedy, and the circumstances in which publication can be justified.

The English court's formulation of a privacy action is an important guide for Malaysia in its preparation of a Privacy Act. Analysis of the New Zealand privacy law provides similar guidance. This is discussed in the next chapter. 


\section{CHAPTER SIX}

\section{PROTECTION OF PRIVACY INTERESTS IN NEW \\ ZEALAND}

\section{Overview}

The English development of privacy, which emerged from the extended version of the action for breach of confidence to encompass misuse of private information, did not prevent New Zealand courts from acknowledging a common law tort of privacy. New Zealand has become the first and only Commonwealth country to recognise a stand-alone privacy tort. The two important requirements of the tort formulated in Hosking $v$ Runting ${ }^{1}$ will be constructively relevant for the proposed statutory tort of privacy for Malaysia.

Before 2004, the tort of invasion of privacy was not part of New Zealand's law. At that time, the protection available for privacy intrusion was piecemeal and derived from the existing common law principles that indirectly protected privacy interests by actions for interference with property rights, liberty and bodily integrity. The common law torts of trespass, assault, nuisance and defamation, harassment, malicious falsehood and passing off were the measures to protect privacy. However, these common law causes of action provide, as in Malaysia, only limited protection against intrusions into privacy. The plaintiff must depend on the coincidence that one of the causes of action fits the facts of the case involved because not all situations of intrusive conduct are covered by the established principles.

The inadequacy of common law principles to address privacy issues has been compensated for by sanctions and remedies from criminal law. From statutes, the protection for privacy interests can be seen through various provisions

${ }^{1}$ [2005] 1 NZLR 1 (CA) (Hosking). 
protecting against intrusive conduct. ${ }^{2}$ The law available has to some extent regulated certain types of privacy invasions such as criminal offences for actions or behaviours that interfere with an individual's privacy.

As discussed in Chapter Two, privacy and dignity are closely related. The essence of dignity is the basis for the protection of privacy and is clearly identified and recognised in case law. ${ }^{3}$ Its importance requires a clear law and a measure to safeguard the interest. It seems that recent development of the law in this area provides means of protecting the interests and overcomes issues of inadequacies of protection in the existing laws.

This chapter evaluates the state of privacy protection in New Zealand. Part II discusses the constitutional support for privacy torts provided under the New Zealand Bill of Rights Act 1990 (NZBORA). Part III evaluates the protection of private information brought about by Hosking. The status of the privacy tort before and after Hosking is discussed in light of the nature of the tort, its scope, requirements and further implication of the development of the tort in the future. Although it is argued that the status of the tort of invasion of privacy is uncertain, ${ }^{4}$ it has, nevertheless, transformed the landscape for privacy protection since Tucker. $^{5}$ Part IV examines the protection against intrusion in the legislation as well as case law. A new tort of intrusion upon seclusion recognised in $C v$ Holland $^{6}$ is discussed in this Part. Part $\mathrm{V}$ concludes the discussion of privacy protection in New Zealand and summarises important values for development in Malaysia.

\footnotetext{
${ }^{2}$ For example ss $216 \mathrm{G}-216 \mathrm{~N}$ of the Crimes Act 1961 renders it an offence to covertly make a visual recording of someone while in an intimate situation, ss 29 and 30 of the Summary Offences Act 1981 make it an offence to be found on property without lawful excuse and to "peep or peer" into a dwelling-house by night. Under s 23 of the Postal Services Act 1998 it is an offence to open letters addressed to someone else.

${ }^{3}$ See Chapter Two, Part III.

${ }^{4}$ This issue will be discussed further in relation to post-Hosking development.

${ }^{5}$ Tucker v News Media Ownership Ltd [1986] 2 NZLR 716 (HC).

${ }^{6}$ [2012] NZHC 2155 (HC) (Holland).
} 
To give a constitutional bearing on the right to privacy will enhance the right as a fundamental one, and thus the question of why it should be protected becomes irrelevant. The following discussion examines the status of the privacy tort in New Zealand's constitutional framework.

\section{Constitutional Support for Privacy Tort}

As discussed in Chapter Three, there is potential for Malaysia to expand the protection of privacy rights from an entrenched right to life and personal liberty. It is, therefore, useful to examine the extent to which similar constitutional developments have been supported in New Zealand.

Unlike Malaysia, New Zealand does not have a written constitution which has the status of superior law, governing all other law of the country and outlining the rights and fundamental freedoms of the citizens. ${ }^{7}$ In New Zealand, the New Zealand Bill Rights Act 1990 (NZBORA) is an ordinary statute and is not entrenched as supreme law. ${ }^{8}$ The Act is best described as a quasiconstitutional instrument. ${ }^{9}$ Tipping $\mathrm{J}$ pointed out that the NZBORA is designed to operate between citizen and State but that it is often appropriate for the values recognised in that context which inform the common law in its function of regulating relationships between citizen and citizen. ${ }^{10}$

The long title of the NZBORA states that its purpose is to affirm, protect and promote human rights and fundamental freedoms in New Zealand and to affirm New Zealand's commitment to the International Covenant on Civil and

\footnotetext{
${ }^{7}$ See Chapter Three, Part II.

${ }^{8}$ The Bill of Rights is an ordinary statute of the Parliament of New Zealand and it is not superior to other legislation. It is not a bill of rights that is imposed upon the legislature by 'the people' nor is it imposed by a superior legislature. It does not purport to invalidate inconsistent legislation, nor to deny inconsistent legislation its intended effect. See Paul Rishworth [et al] The New Zealand Bill of Rights (Oxford University Press, Melbourne, 2003) at 2 .

${ }^{9}$ Andrew Butler and Petra Butler The New Zealand Bill of Rights Act: A Commentary (LexisNexis, Wellington, 2005) at 9.

${ }^{10}$ Hosking, at [229].
} 
Political Rights (ICCPR). ${ }^{11}$ Nothing equivalent to art 17 of the ICCPR or any statement of the general right to privacy which is recognised in the ICCPR, can be found in the NZBORA. According to A Bill of Rights for New Zealand: A White Paper published in 1985: ${ }^{12}$

The Bill (like the Canadian Charter) gives no general guarantee of privacy. There is not in New Zealand any general right to privacy, although specific rules of law and legislation protect some aspects of privacy. It would be inappropriate therefore to attempt to entrench a right that is not by any means fully recognised now, which is in the course of development, and whose boundaries would be uncertain and contentious.

The above acknowledged that the right to privacy is not specifically provided for in the NZBORA. Burrows commented on New Zealand's human rights framework and the uncodified right of privacy: ${ }^{13}$

Our jurisprudence is becoming more rights-based. That movement is international, and is evidenced in New Zealand in particular by the New Zealand Bill of Rights Act 1990. Although our Bill of Rights Act does not specifically codify a right of privacy, it has sensitised us to the essential dignity of the individual.

However, as pointed out by Gault P in Hosking, the omission of the right to privacy in the NZBORA does not imply the rejection of privacy as an

\footnotetext{
${ }^{11}$ Article 17 of the ICCPR provides a right to privacy. "(1) No one shall be subjected to arbitrary or unlawful interference with his privacy, family, home or correspondence, nor to unlawful attacks on his honour and reputation. (2) Everyone has the right to the protection of the law against such interference or attacks."

${ }^{12}$ Minister of Justice A Bill of Rights for New Zealand: A White Paper (Department of Justice, Wellington, 1985) 103-104, at [10.144].

${ }^{13}$ John Burrows "Invasion of Privacy" in Stephen Todd (ed) The Law of Torts in New Zealand (6th ed, Thomson Reuters, Wellington, 2013) at 943.
} 
internationally recognised fundamental value. In fact, His Honour accepted that the scope for privacy law should be left for incremental development. Because of the broadness of the concept of privacy, issues of definition, scope of protection and relationship with other human values clearly would have defeated any attempt to comprehensively delineate the legal principles. ${ }^{14}$

The non-recognition of the right to privacy in the NZBORA suggests that rights and freedoms expressly contained within it have a different status from rights and freedoms that are excluded. However, this statement is complemented by s 28 , where an existing right or freedom is not abrogated or restricted because it is not included or not fully included in NZBORA. ${ }^{15}$ Thus, the omission of the right to privacy does not mean that it does not exist or is of less weight. Furthermore, New Zealand remains obliged at international law to protect the citizen's right to privacy and to ensure an effective remedy for its breach.

\section{A Privacy and Freedom of Expression}

The fact that the right to privacy is not a right in the NZBORA does not diminish its value or the importance of individual dignity. Despite the absence of express recognition, considerations of privacy may arise from other recognised rights established under the NZBORA such as freedom of expression, ${ }^{16}$ freedom from discrimination ${ }^{17}$ and freedom from unreasonable

\footnotetext{
${ }^{14}$ Hosking at [92].

${ }^{15}$ Section 28 provides that an existing right or freedom shall not be held to be abrogated or restricted by reason only that the right or freedom is not included in this Bill of Rights or is included only in part. Paul Rishworth commented "It also goes without saying that the recognition of other rights in s 28 does not mean that those other rights are to be treated as if they are affirmed by the Bill of Rights. The point of the Bill of Rights is to affirm the rights it affirms, while recognising in s 28 that there are other rights that it has not affirmed" in $\mathrm{P}$ Rishworth, G Huscroft, S Optican and R Mahoney The New Zealand Bill of Rights (Oxford University Press, Oxford, 2003).

${ }^{16}$ Section 14.

${ }^{17}$ Section 19 provides that "(1) Everyone has the right to freedom from discrimination on the grounds of discrimination in the Human Rights Act 1993. (2) Measures taken in good faith for
} 
search and seizure. ${ }^{18}$ Section 14 provides that "Everyone has the right to freedom of expression, including the freedom to seek, receive, and impart information and opinions of any kind in any form."

It is generally accepted that freedom of expression is one of the fundamental liberties of a modern democracy. However, the rights established under the NZBORA are not absolute and are subject to limitations. This is stated in $\mathrm{s}$ $5:^{19}$

The rights and freedoms contained in this Bill of Rights may be subject only to such reasonable limits prescribed by law as can be demonstrably justified in a free and democratic society.

The above provision sets out "reasonable limits prescribed by the law" and "demonstrably justified" elements before freedom of expression gives way to privacy. Freedom of expression, therefore, is fundamental, not absolute. It may be limited by other rules and statutes that are reasonable and demonstrably justified in a free and democratic society as prescribed by $\mathrm{s} 5$. Concerning this limitation, Gault P and Blanchard J observed: ${ }^{20}$

While developments in the common law must be consistent with the rights and freedoms contained in the Bill of Rights Act, such developments are not precluded merely because they might encroach upon those rights and freedoms. It becomes a matter of

the purpose of assisting or advancing persons or groups of persons disadvantaged because of discrimination that is unlawful by virtue of Part 2 of the Human Rights Act 1993 do not constitute discrimination."

${ }^{18}$ Section 21 Unreasonable search and seizure provides "Everyone has the right to be secure against unreasonable search or seizure, whether of the person, property, or correspondence or otherwise."

${ }^{19}$ Article 19(3) of the ICCPR is of the same effect where it states "the exercise of the rights provided for in paragraph 2 of this art carries with it special duties and responsibilities. It may, therefore, be subject to certain restrictions, but these shall only be such as are provided by law and are necessary (a) for respect of the rights or reputation of others; (b) for the protection of national security or public order (ordre public), or of public health or morals."

${ }^{20}$ Hosking at [111]. 
whether such common law encroachment meets the test of a reasonable limit on the applicable right or freedom which is demonstrably justified in a democratic society in s 5 .

Although no further explanation was given as to how privacy might provide a reasonable limit on freedom of expression, the court resolved this by suggesting a balancing mechanism between the competing values. Gault $\mathrm{P}$ and Blanchard $\mathrm{J}$ recommended the reconciliation between the desirability of protecting from publication and the necessity for dissemination of information. A balance must be struck so that the competing interests accommodate personal and private information. ${ }^{21}$

However, the minority in Hosking argued that the general tort of privacy would have a chilling effect on freedom of expression. Keith J stated: ${ }^{22}$

the proposed tort of public disclosure of private facts would place a generally stated limit on the centrally important right to freedom of expression; it would depart, without good reason, from long established approaches to the protection of personal information; those approaches are based on identifying particular privacy interests which call for protection and determining the components of the protection... and involve making particular choices of remedy; and finally, the proposed limit has not been demonstrably justified, as s 5 of the Bill of Rights requires.

Thomas $\mathbf{J}$ in his dissenting judgment in Brooker $v$ Police ${ }^{23}$ asserted that both freedom of expression and privacy should be recognised as fundamental values and accorded neither presumptive nor paramount status but weighed

\footnotetext{
${ }^{21}$ At [116].

${ }^{22}$ Hosking, at [222].

${ }^{23}$ [2007] 3 NZLR 91; [2007] CRNZ 346 (SC) (Brooker).
} 
one against the other in a manner designed to afford greater protection to both. $^{24}$

Thus, in Hosking, the judges were divided on the issue of the effect of the privacy tort on free speech. While the majority strongly accepted that the resulting limitation was prescribed by the law and justified, the minority rejected the argument and submitted otherwise. In this regard, Tipping J's analysis of s 5 on freedom of expression and privacy is of great importance. His Honour held that privacy values would not normally constitute a justified limitation on freedom of expression if the information being imparted was a matter of legitimate public concern. ${ }^{25}$ If the public has a right to know matters that related to the maintenance of democratic process, then the dissemination of the information is not subject to limitation. Tipping $\mathrm{J}$ finally concluded that: ${ }^{26}$

\footnotetext{
When privacy values are found to outweigh the right to freedom of expression, that limitation will, in terms of s 5 of the Bill of Rights, be a limit prescribed by law. It will also be a limit which is reasonable and demonstrably justified in a free and democratic society.
}

\section{B Privacy and Unreasonable Search and Seizure}

Another right under the NZBORA which relates to privacy is the scope of the right to be free from unreasonable search and seizure in s 21 . This has been considered in the light of "reasonable expectations of privacy". The New Zealand Bill of Rights Act 1990, unlike the ECHR, does not contain any guarantees for the protection of individuals' privacy apart from the s 21 right to be secure from unreasonable search and seizure.

\footnotetext{
${ }^{24}$ At [164].

${ }^{25}$ At [233.]

${ }^{26}$ At [237].
} 
Section 21 permits searches which are reasonable to interfere with a reasonable expectation of privacy, and even where the search is unreasonable, other competing factors may outweigh the privacy interest involved. In respect of s 21, which has been considered to have an implicit recognition of the right to privacy, in particular intrusion into personal privacy, Tipping $\mathrm{J}$ in Hosking said: ${ }^{27}$

...the values that underpin s 21 and which are reinforced by New Zealand's international obligations can, by reasonable analogy, be extended to unreasonable intrusions into personal privacy which may not strictly amount to search and seizure. The lack of any express recognition of a right to privacy in the Bill of Rights should not inhibit common law developments found to be appropriate.

The earlier case of $R v$ Jefferies $^{28}$ also touched on the importance role of s 21 to recognise the right to privacy in modern times: ${ }^{29}$

Essentially, s 21 is concerned to protect those values or interests which make up the concept of privacy. Privacy connotes a variety of related values; the protection of one's property against uninvited trespass; the security of one's person and property, particularly against the might and power of the state; the preservation of personal liberty; freedom of conscience; the right of self-determination and control over knowledge about oneself and when, how and to what extent it will be imparted; and recognition of the dignity and intrinsic importance of the individual. While necessarily phrased in terms of individual values, the community has a direct interest in the recognition and protection of this broad right to privacy.

\footnotetext{
${ }^{27}$ Hosking, at [226].

${ }^{28}$ [1994] 1 NZLR 290. See also Steven Penk \& Rosemary Tobin (ed) Privacy Law in New Zealand (Brookers Ltd, Wellington, 2010) at 149.

${ }^{29} R v$ Jefferies, at 319.
} 
It is a valued right which is esteemed in modern democratic societies.

The discussion in this Part acknowledges the importance of the right to privacy along with other rights provided by the statute. Although there is no direct privacy right enforceable against the state in the NZBORA as compared to England, the court is free to develop a common law protection. The omission of the right to privacy as a recognised right similar to that of expression does not prevent the Act from affirming commitment to a Covenant that includes privacy as one of its fundamental rights. This position indicates that it is appropriate for the judiciary to recognise the broad concept of privacy within the values upheld by s $21 .^{30}$

The absence of a general right to privacy in the NZBORA does not necessarily mean that the New Zealand legal framework lacks protection for certain aspects of privacy interests. The next Part discusses the protection of private information in New Zealand.

\section{Protection of private information}

The non-existence of an express protection of privacy in New Zealand law until the last quarter of the $20^{\text {th }}$ century is not an indication that privacy failed to gain its place in New Zealand legal framework. In fact, it is a value which is present in certain situations, but indirectly. Burrows suggests that "privacy has been recognised for a long time as an underlying value worth protecting, even if that protection has been partial and very poorly articulated". ${ }^{31}$

\footnotetext{
${ }^{30}$ See Stacey Lulham "What Is, and What Should Be, The Extent of New Zealand's New Tort of Breach of Privacy?" (2005) 11 Canterbury Law Rev 91, at 98.

${ }^{31}$ Burrows, above n 13 at 938.
} 
In this Part, the judicial development of privacy protection is discussed, particularly the position before Hosking. The discussion shows that a greater protection of privacy has been achieved through case law. The next sections discuss fundamental characteristics of Hosking tort and the impact of the Hosking on privacy law in New Zealand.

\title{
A Common Law Privacy Tort: Pre-Hosking
}

It is now settled that a common law tort of infringement of privacy involving the unwarranted publication of private facts existed in New Zealand. ${ }^{32}$ Before it was recognised in Hosking, privacy gained the attention of the courts which became increasingly aware of privacy as a value. In the case of Auckland Medical Aid Trust $v$ Taylor ${ }^{33}$, the court declared a search warrant to be unlawful as it interfered with a person's privacy. Although Taylor was not a tort case, the protection for privacy against intrusion as a value worth protecting was considered by the court in its decision. In the words of McCarthy $\mathrm{P}:{ }^{34}$

\begin{abstract}
In my view, it would be contrary to the role which Courts of our tradition have always adopted of protecting the integrity of a man's premises and of viewing in a conservative way the extension of statutory powers to interfere with privacy, if we were to uphold the warrant in this case.
\end{abstract}

The above position had its basis in the leading case Entick $v$ Carrington $^{35}$ in which the court stressed the link between property and privacy. Lord Camden stated that:

\footnotetext{
${ }^{32}$ Rosemary Tobin "Invasion of Privacy" [2000] NZLJ 216, at 222. She said that "it is beyond doubt that a tort of privacy exists in New Zealand" when commented on $P v D$ [2000] 2 NZLR 591.

${ }^{33}$ [1975] 1 NZLR 728 (CA).

${ }^{34}$ At 737.

${ }^{35}(1765) 19$ State Trials 1029.
} 
The great end, for which men entered into society, was to secure their property. That right is preserved sacred and incommunicable in all instances, where it has not been taken away or abridged by some public law for the good of the whole ... If no excuse can be found or produced, the silence of the books is an authority against the defendant, and the plaintiff must have judgment.

The development of a privacy interest can be seen further in the case of Tucker $v$ News Media Ownership Ltd ${ }^{36}$ where the judge was of the view that a person had a right to be left alone and to live the private aspects of their life without being subjected to unwarranted or undesired publicity or public disclosure. It was arguable whether a tort of invasion of privacy did exist. The case concerned the application of an interim injunction sought against certain media organisations from publishing details of the criminal past of a man who sought public donations for a life-saving heart transplant operation. Jeffries $\mathbf{J}$ said $^{37}$ that the gist of a privacy action is not injury to character or reputation but to a person's feelings and peace of mind as a result of the unwarranted publication of intimate details of a plaintiff's private life which are outside the realm of legitimate public concern or curiosity. Consequently, the right to privacy in the circumstances before the court may provide the plaintiff with a valid cause of action in New Zealand. McGechan J said that he supported "a tort covering invasion of personal privacy at least by public disclosure of private facts". 38

In $P v D,{ }^{39} \mathrm{P}$ sought an interim injunction to prevent the defendant journalist and newspaper publishing information that he or she had been treated at a psychiatric hospital and had been attended to by a police officer in an emergency situation. Nicholson $\mathbf{J}$ considered that a tort of infringement of

\footnotetext{
${ }^{36}[1986] 2$ NZLR 716 (HC).

${ }^{37}$ At 716.

${ }^{38}$ At 733 .

${ }^{39}$ [2000] 2 NZLR 591.
} 
privacy encompassing public disclosure of private facts did exist in New Zealand, and he awarded an injunction to the plaintiff on that basis. A claim for breach of confidence would not have succeeded because the information obtained by the journalist could have been received from a person who was not under a duty of confidence, such as a member of the public, and, therefore, could not be said to have been imparted in circumstances importing an obligation of confidence. Nicholson J said that: ${ }^{40}$

The right of freedom of expression is not an unlimited and unqualified right and in my view is subject to limitations of privacy as well as other limitations such as indecency and defamation.

The judge said that treatment at a psychiatric hospital was clearly a private fact, and disclosure of that information by a newspaper or other media would be public disclosure. The "highly offensive" requirement involved an objective test and the publication that someone had been a patient in a psychiatric hospital would be highly offensive and objectionable to a reasonable person of ordinary sensibilities. In granting the injunction the judge concluded that disclosure of the fact of a psychiatric disorder in the current social climate could be considered highly objectionable to a reasonable person. There was no legitimate public interest in publication of the information. The decision was based on the formulation of the tort of breach of privacy set out earlier by Gallen $\mathrm{J}$ in Bradley $v$ Wingnut Films Ltd. ${ }^{41}$ The tort consisted of four factors:

a) That the disclosure of the private facts must be a public disclosure and not a private one;

b) Facts disclosed to the public must be private facts and not public ones;

c) The matter made public must be one which would be highly offensive and objectionable to a reasonable person of ordinary sensibilities; and

\footnotetext{
${ }^{40}$ At 599 .

${ }^{41}$ [1993] 1 NZLR 415.
} 
d) The nature and extent of legitimate public interest in having the information disclosed must be weighed.

Gallen $\mathrm{J}$ followed McGechan $\mathrm{J}$ in Tucker on the existence of a new tort but added that the extent of the development of the tort should be regarded with caution. Such caution was necessary because of the difficulty of formulating boundaries on the tort to ensure that the rights and concerns of the individual are balanced against the significance in a free country of freedom of expression. ${ }^{42}$ The facts of Bradley failed to satisfy the private fact and highly offensive requirement as it did not involve a matter of public concern.

In the District Court, Abbott DCJ in $L v G^{43}$ said that it was apparent that New Zealand law recognised that breach of privacy is an actionable tort. ${ }^{44}$ The plaintiff who was a sex worker had sexual relations with the defendant client. The client published photographs of the plaintiff in an adult lifestyle magazine without the plaintiff's consent. Although the plaintiff could not be identified in the photograph, Abbott $\mathrm{J}$ had no hesitation in concluding that breach of privacy is an actionable tort in New Zealand, and that the defendant's action had destroyed her personal shield of privacy. ${ }^{45}$ On holding that the requirements of a tort of breach of privacy were fulfilled, damages were awarded to the plaintiff.

There has been growing authority in New Zealand that there is a separate tort of invasion of privacy which provides a cause of action independent from other branches of privacy-related protection under common law.

In terms of remedies, the High Court judges had been granting interim injunctions on the basis that it was arguable that there was a tort of invasion of

\footnotetext{
${ }^{42}$ At 423 .

${ }^{43}$ [2002] DCR 234 (DC).

${ }^{44}$ At 241.

${ }^{45}$ At 246.
} 
privacy. ${ }^{46}$ However, $L v G^{47}$ was the first case in New Zealand where damages instead of injunction were granted for the breach. The development of a tort of public disclosure of private facts that had preceded this was later affirmed by a majority of 3:2 in the Court of Appeal in Hosking $v$ Runting. The majority decided that there was indeed a tort of invasion of privacy in New Zealand. It protected against offensive publicity being given to private facts. The recognition of the tort should not be regarded as settled, ${ }^{48}$ rather this is just the beginning of the evolution of a privacy tort.

\section{B Hosking $v$ Runting}

\section{$1 \quad$ Background of facts and decision}

The Court of Appeal in Hosking confirmed the existence of a tort protecting information privacy in New Zealand. This was a significant decision as Randerson $\mathbf{J}$ in the High Court ${ }^{49}$ had rejected the reasoning of earlier cases that had recognised a tort of privacy. ${ }^{50} \mathrm{He}$ had expressed a preference for New Zealand to develop the breach of confidence action as had occurred in the United Kingdom. The judgment was criticised for throwing the development of the tort of invasion of privacy into reverse. ${ }^{51}$

In Hosking, a photographer was commissioned by New Idea! magazine to photograph the 18-month-old twin daughters of television personality Mike Hosking, after his separation from his wife. Magazines had previously published articles about the Hoskings, touching on a range of personal

\footnotetext{
${ }^{46}$ This trends can be seen in Tucker $v$ News Media Ownership Ltd [1986] 2 NZLR 716 and $P v$ $D$ [2000] 2 NZLR 591.

${ }^{47}$ Above $\mathrm{n} 43$

${ }^{48}$ Rogers v Television New Zealand [2008] 2 NZLR 277; [2007] NZSC 91 at [26] per Elias CJ, [144] per Anderson J. ${ }^{49}$ Reported at [2003] 3 NZLR 285 (HC).

${ }^{50}$ The recognition were expressed in Tucker above n 36, Bradley above n 41, $P \vee D$ above $\mathrm{n}$ 39 and $L v G$ above $\mathrm{n} 43$.

${ }^{51}$ Rosemary Tobin "Privacy: one step forward, two steps back!" [2003] NZLJ 256.
} 
matters. However, following the birth of the twins, the Hoskings declined further publicity including giving interviews or allowing photographs of the twins to be taken. The couple separated in August 2002. During that year, New Idea! proposed an article on the change to Mr Hosking's personal life, and the fact that he would be spending Christmas without the company of his children. Photographs of the children in the street being pushed in their stroller by their mother supplemented the article that was to be published in the 2002 Christmas edition. On learning that the photographs had been taken and were to be published, the Hoskings sought an injunction restraining the magazine from taking and publishing photographs of the twins, arguing that photographing the children and publishing the photographs without consent amounted to a breach of the twins' privacy.

In the High Court, Randerson $\mathbf{J}$ said that a claim in breach of confidence could not be sustained, because the photographs were taken while the children were in a public place. The judge, therefore, concerned himself solely with whether a freestanding tort of privacy existed in New Zealand and, if so, whether it would cover this situation so as to provide a remedy for appellants. He examined a number of New Zealand authorities that had cautiously recognised a separate tort of privacy then considered the approach of the courts in the UK, where a common law privacy tort was not recognised. Instead, the English Court of Appeal had developed the equitable cause of action of breach of confidence which prevented the publication of private information in certain circumstances. Randerson J reviewed authorities from Australia, Canada and the US, finding that only the US recognised a separate tort of privacy, and that the right to privacy is generally outweighed by the First Amendment right to freedom of expression. ${ }^{52}$

Randerson $\mathbf{J}$ concluded that New Zealand courts should not recognise a privacy tort, and that any gaps in privacy law should be filled by the

\footnotetext{
${ }^{52}$ Gault $\mathrm{P}$ at [14].
} 
legislature not the courts. ${ }^{53} \mathrm{He}$ considered that, in any event, granting a remedy preventing public disclosure of photographs of children taken in a public place went beyond the scope of previous New Zealand authority and did not fit the tort of privacy set down in the judgment of Nicholson $\mathrm{J}$ in the High Court in $P v D .{ }^{54}$ Randerson $\mathrm{J}$ considered that there was no public disclosure of private facts. In addition, the photographs could not be described as offensive to persons of ordinary sensibilities and thus, the claim failed. ${ }^{55}$

On appeal, the Court of Appeal unanimously agreed that the Hoskings must fail on the facts. The photographs were taken in a public place; there was no risk to the children and the photographs disclosed no further facts about them. Thus, no reasonable person could treat their publication as highly offensive or objectionable. The court dismissed the appeal and held that it was not strictly necessary to decide whether a right of action for wrongful publication of private information existed in common law in New Zealand.

However, a majority (Gault P, Blanchard and Tipping JJ) stated that a tort of invasion of privacy by publicity given to private facts did exist in New Zealand. The judges highlighted certain aspects of the newly acknowledged tort of invasion of privacy covering the unjustified publication of private information. ${ }^{56}$

They added that a defence existed enabling publication to be justified by a legitimate public concern for the information. The burden of proving the defence is on the defendant, and is not available where the matter is of no more than general interest or titillation, or gives rise to curiosity.

\footnotetext{
${ }^{53}$ At [15].

${ }^{54} P \vee D$, above n 39 .

${ }^{55}$ Hosking, at [16].

${ }^{56}$ At [117], [118], [249], [250].
} 
The recognition of the privacy tort was very much influenced by the third formulation of the privacy tort identified by Prosser and developed in the US cases. ${ }^{57}$ Hosking changed the New Zealand legal framework of protecting privacy by the application of common law principles to a separate tort of public disclosure of private facts. Once a prima facie breach of privacy is established, a defence of "legitimate public concern" is available. The recognised action, however, does not deal with unreasonable intrusion into solitude. The tort concerns itself with publicity (not facts) highly offensive to the reasonable person. The harm protected against is humiliation and distress.

Tipping J's formulation of the privacy tort is slightly wider than that of Gault $\mathrm{P}$ and Blanchard JJ's. His summary of the tort is essential for describing its position in New Zealand privacy law: ${ }^{58}$

It is actionable as a tort to publish information or material in respect of which the plaintiff has a reasonable expectation of privacy, unless that information or material constitutes a matter of legitimate public concern justifying publication in the public interest. Whether the plaintiff has a reasonable expectation of privacy depends largely on whether publication of the information or material about the plaintiff's private life would in the particular circumstances cause substantial offence to a reasonable person. Whether there is sufficient public concern about the information or material to justify the publication will depend on whether in the circumstances those to whom the publication is made can reasonably be said to have a right to be informed about it.

\footnotetext{
${ }^{57}$ Section 652D of the Second Restatement Tort (1977) states that "privacy tort protection exists where (3) One who gives publicity to a matter concerning the private life of another is subject to liability to the other for invasion of his privacy, if the matter publicized is of a kind that (a) would be highly offensive to a reasonable person, and (b) is not of legitimate concern to the public". See also Hosking at [68], [118].

${ }^{58}$ At [259]. It is important to note that, although Tipping $\mathbf{J}$ is in agreement with the other two judges of the majority who support the existence of the tort of invasion of privacy, His Honour slightly differs from the joint judgment of Gault $\mathrm{P}$ and Blanchard $\mathrm{J}$ in the formulation of the action and its requirements.
} 
The minority did not support the existence of the tort: ${ }^{59}$

The approach of Parliament in leaving issues of "privacy" to be developed by expert bodies and in deliberately excluding the news media in its news gathering capacity from the scope of the general privacy legislation militates against the finding of a new tort of giving unreasonable publicity to private facts.

Anderson $\mathrm{J}$, in the minority, expressed the view that there was no demonstrable need for an extension of civil liability and in fact the extended liability could be incidentally harmful to the right of freedom of expression for two reasons. First, there is the ability of a plaintiff, aggrieved by the prospective publication of truth, to be able to prevent publication by an injunction. Second, the new tort is imprecise in its definition, both semantically and in terms of its application in reality. His Honour found that the new liability was created "in a side wind", is amorphous, unnecessary, a disproportionate response to rare, almost hypothetical circumstances and fell manifestly short of justifying its limitation on the right to freedom of expression affirmed by the NZBORA. ${ }^{60}$

Keith $\mathbf{J}$, also in the minority, noted that a separate cause of action for giving unreasonable publicity to private facts does not exist in the common law of New Zealand. He said the proposed tort would place a limit on the centrally important right to freedom of expression and would depart without good reason from long established approaches to the protection of personal information. Those approaches are based on identifying particular privacy interests which call for protection and determine the components of the protection and involve making particular choices of remedy. This final reason

\footnotetext{
${ }^{59}$ At [201], [204]-[206], [267].

${ }^{60}$ At [270], [271].
} 
was that the proposed limit had not been demonstrably justified, as required by 5 of the NZBORA. ${ }^{61}$

\title{
2 The rejection of the UK approach
}

The English approach in Douglas influenced New Zealand in developing its privacy law. In the High Court, Randerson $\mathrm{J}$ in Hosking $v$ Runting ${ }^{62}$ indicated a preference to follow the UK approach of protecting privacy: ${ }^{63}$

\begin{abstract}
I see no reason why our courts should not develop the action for breach of confidence to protect personal privacy through the public disclosure of private information where it is warranted. In so doing, it should be informed by the recent developments in the UK and elsewhere while taking into account New Zealand law and conditions.
\end{abstract}

At the end of his judgment, Randerson $\mathrm{J}$ concluded that the law of privacy could be developed by the courts on the equitable action for breach of confidence. Further treatment to privacy outside the boundary of the law of confidence should be left to Parliament.

In response to the High Court view on applying breach of confidence to privacy action, Keith $\mathrm{J}$ noted some difficulty in applying the law of confidence to situations in which there is no relationship between the parties: ${ }^{64}$

The very word "confidence", its origin and the body of law surrounding it appear to me all to require that an element of trust or something equivalent exist between the parties.

\footnotetext{
${ }^{61}$ At [222].

${ }^{62}$ Hosking $v$ Runting [2003] 3 NZLR 385 (HC).

${ }^{63}$ Randerson J at [158]. Hosking, at [44].

${ }^{64}$ Hosking, at [201].
} 
Gault P stated that privacy and confidence are different concepts. His Honour found it confusing to utilise a breach of confidence action based on trust and confidence to a case of unwarranted exposure of information about the private lives of individuals. He said: ${ }^{65}$

\begin{abstract}
If breach of confidence is to be used as the privacy remedy in New Zealand, then the requirement of a confidential relationship must necessarily change. ..The English authorities seem largely to ignore the fact that Lord Goff's dictum was only directed at exceptional cases where the relevant information was "obviously confidential", yet no confidential relationship existed. The expansion of the focus of the cause of action was not contemplated by him to change the nature of the information disclosed, but rather the nature of the relationship or circumstances of the parties.
\end{abstract}

Tipping $\mathrm{J}$ while supporting the existence of a privacy tort, acknowledged the circumstances in which reasonable expectation of privacy would arise, including conventional confidentiality issues. However, His Honour held that although confidence and privacy are capable of overlapping, they are essentially different concepts: ${ }^{66}$

\begin{abstract}
Breach of confidence, being an equitable concept, is conscience based. Invasion of privacy is a common law wrong which is founded on the harm done to the plaintiff by conduct which can reasonably be regarded as offensive to human values.
\end{abstract}

His Honour also allowed for the possibility of developing the equitable cause of action to achieve the aim of privacy protection, but preferred a selfcontained and stand-alone common law cause of action known as invasion of

\footnotetext{
${ }^{65}$ At [48]-[49].

${ }^{66}$ At [246].
} 
privacy, and thus rejected the UK method of extending the breach of confidence action.

3 Requirements of the privacy tort

\section{(a) Reasonable expectation of privacy}

The first requirement of the tort of public disclosure of private facts is "reasonable expectation of privacy". This formulation also appeared in English cases when determining privacy cases. ${ }^{67}$ The expression "facts in respect of which there is a reasonable expectation of privacy" is not easy to define. Gault $\mathrm{P}$ said that in many instances the identification of private facts will be analogous to the test of "information with the necessary quality of confidence" employed in breach of confidence cases and that there was no simple test for what constitutes a private fact. "Private facts" are those that may be known to some people, but not to the world at large. ${ }^{68}$ According to Burrows, "private facts" suggest inherently intimate personal facts about a person, such as personal relationships, financial matters and medical conditions. They may cover any facts that can be reasonably expected will not be published. ${ }^{69}$

The court in Hosking referred to ABC v Lenah Game Meats Pty Ltd where Gleeson CJ gave his comments on what is private fact: ${ }^{70}$

There is no bright line which can be drawn between what is private and what is not. Use of the term "public" is often a convenient method of contrast, but there is a large area in between what is necessarily public and what is necessarily private. An activity is not private simply because it is not done in public. It does not suffice to

\footnotetext{
${ }^{67}$ See A v B plc [2002] 2 All ER 545 (CA), Campbell v MGN Ltd [2004] 2 AC 457 (HL).

${ }^{68}$ Hosking at [119].

${ }^{69}$ John Burrows "Invasion of Privacy - Hosking and Beyond" [2006] NZ Law Rev 389 at 392.

${ }^{70}$ ABC v Lenah Game Meats Pty Ltd [2001] 208 CLR 199 (HCA), at [42].
} 
make an act private that, because it occurs on private property, it has such measures of protection from public gaze as the characteristics of the property, the nature of the activity, the locality, and the disposition of the property owner combine to afford. Certain kinds of information about a person, such as information relating to health, personal relationships, or finances, may be easy to identify as private; as may certain kinds of activity, which a reasonable person, applying contemporary standards of morals and behavior, would understand to be meant to be unobserved.

Tipping $\mathrm{J}$ supported the concept of a reasonable expectation of privacy and commented that a precise concept of a reasonable expectation of privacy is not possible at an early development of the tort. ${ }^{71}$

His Honour believed that the fundamental ingredient of the tort should be that the plaintiff must be able to show a reasonable expectation of privacy in respect of the information or material the defendant has published or wishes to publish. In this circumstance, the expectation can arise from the nature of the information or material the defendant came to possess. His Honour described how the test works: ${ }^{72}$

The plaintiff must show first an expectation of privacy and, more importantly in most cases, that such expectation is a reasonable one. The latter dimension of reasonableness, familiar in any field of law, controls the subjective expectation of the individual. It introduces an objective element upon which, as with all questions of reasonableness, in the end the Court has to make a value judgment. It is a very familiar exercise and cannot, in my view, validly be criticised on the basis of uncertainty. The concept is clear. The fact that its application in a marginal case

\footnotetext{
${ }^{71}$ At [249].

${ }^{72}$ At [250].
} 
may be difficult is not a valid reason to regard the concept as possessing objectionable uncertainty.

The test of reasonable expectation of privacy is determined objectively by the facts and whether they were actionable or not from the perspective of the reasonable person. Thus, in Hosking the test is purely objective: what would a reasonable person considering the matter think and feel. Similarly, the same applies in Campbell where the test is assessed from the perspective of a reasonable person looking at the facts and circumstances of the case: how would a reasonable person in the position of the subject of the photograph feel about the publication of the photograph. All factors surrounding the photograph: whether it was taken surreptitiously or otherwise, should be taken into account in determining whether a reasonable expectation of privacy in the matters concerned exists.

Gleeson CJ's guidelines of private facts provide important criteria on how to distinguish between public and private facts. However, it does not settle related issues to private facts when they involve public figures. Hosking involved the children of public figures. Earlier at the High Court, Randerson J examined what reasonable expectations of privacy Hosking families were entitled to. His Honour stated that the reasonable expectation of privacy of public figures will necessarily be lower since it is inevitable the media subject celebrity figures to close scrutiny because the public has a natural curiosity and interest in the personal lives and activities of celebrities and those close to them. ${ }^{73}$

The question posed by Gault $\mathrm{P}$ and Blanchard $\mathrm{J}$ is, "Should public figures have lower expectations of privacy in relation to their private lives, and how does this impact on the families of public persons" ${ }^{74}$ The judges observed

\footnotetext{
${ }^{73}$ Hosking (HC) at [141].

${ }^{74}$ Hosking at [120].
} 
that US jurisprudence provides that the right of privacy of public figures is held to have been lost because (1) by seeking publicity they have consented to it; (2) their personalities and affairs are already public facts not private ones; (3) there is a legitimate public interest in the publication of details about public figures ${ }^{75}$ It is not entirely clear to what extent the judges were endorsing the US position. It is clear that the third factor was recognised in Hosking as part of the public interest defence for the tort. ${ }^{76}$ The judges also stress, though, that not all of public figures' activities are of concern to the public, it is just that the level of expectations of privacy is reduced in cases involving public figures. Gault $\mathrm{P}$ and Blanchard $\mathrm{J}$ recognised: ${ }^{77}$

It is a matter of human nature that interest in the lives of public figures also extends to interest in the lives of their families. In such cases the reasonable expectations of privacy in relation to at least some facts of the family's private lives may be diminished.

UK courts acknowledged that a public figure is entitled to a private life and submitted that an individual in a public position must expect his actions to be more closely scrutinized by the media. In $A v B$ plc Lord Woolf CJ commented on the level of expectation: ${ }^{78}$

The right of privacy is not automatically lost when a person is a public figure, but his or her reasonable expectation of privacy in relation to many areas of life will be correspondingly reduced as public status increases. Involuntary public figures may also experience a lessening of expectation of privacy, but not ordinarily to the extent of those who willingly put themselves in the spotlight.

\footnotetext{
${ }^{75}$ At $[120]$.

${ }^{76}$ At [120].

${ }^{77}$ At [124].

${ }^{78} A \cup B$ plc [2002] 2 All ER 545 (AC), at 554.
} 
In Hosking, Gault P and Blanchard JJ acknowledged the vulnerability of children and the courts might be expected to be more sensitive to the interests of the children of "celebrities" but in the context of the protection of privacy, the test of reasonable expectation of privacy provides adequate flexibility to accommodate that special vulnerability of children.

In exceptional cases, a reasonable expectation of privacy can arise in relation to information gathered in a public place. ${ }^{79}$ However, the expectation did not arise in Hosking because the public activities of Mrs Hosking and her children were not exceptional.

The second requirement of the tort which concerns the test of material of a "highly offensive" nature and its application to a reasonable expectation of privacy is discussed in the next section.

\section{(b) Highly offensive to an objective reasonable person}

In order to safeguard other interests that may collide with the new tort, especially freedom of expression, the Court of Appeal prescribed that not only that must there be a reasonable expectation of privacy, but also that the publication of the facts must be highly offensive to an objective reasonable person. ${ }^{80}$ The test assumes a high threshold for a plaintiff to surmount. The primary concern is with publicity "that is truly humiliating and distressful or otherwise harmful to the individual concerned". Therefore, the right of action should be only in respect of publicity determined objectively by reference to its extent and nature, to be offensive by causing real hurt or harm. ${ }^{81}$ It is offensive publicity that is the gist of the action, rather than that the facts are offensive in themselves. ${ }^{82}$

\footnotetext{
${ }^{79}$ Hosking, at [164]. See also, Ursula Cheer "The Future of Privacy Recent Legal Developments in New Zealand" (2007) 13 Canterbury Law Rev 169, at 176.

${ }^{80}$ Hosking, at [127].

${ }^{81}$ At [126].

${ }^{82}$ See John Burrows, above n 69, at 396 where the author stated that the offensiveness focuses on the publicity rather than on the private facts.
} 
Gault $\mathrm{P}$ and Blanchard $\mathrm{J}$ considered the test of highly offensive to the reasonable person is appropriate as it relates to publicity and is not part of the test to determine whether information is private. ${ }^{83}$ The test is also necessary as a control mechanism over the types of publicity within the scope of the privacy action. It will exclude legal liability for all publications of private information. ${ }^{84}$

Tipping $\mathbf{J}^{85}$ although in general agreement with the joint judgment preferred that the level of offensiveness to be a substantial, not a high level of offence and to be dealt with within the requirement of a reasonable expectation of privacy, and in fact that the highly offensive test should not be a requirement at all. This is more flexible while at the same time capturing the essence of the matter. His reason was that disclosure must be at least substantially offensive so that expression is not too readily limited and that trivial breaches are not actionable. His Honour envisaged circumstances where it would be unduly restrictive to require a high level of offence, for example that the publication served little or no public good, save an abstract upholding of the liberty theory. ${ }^{86}$

Moreham suggested that "offence" is an inappropriate way to describe what is suffered. ${ }^{87}$ She submitted that the highly offensive publicity test is not necessary to keep the privacy action within bounds because the test of reasonable expectation of privacy itself operates to exclude non-serious claims. ${ }^{88}$ Instead, she recommended tests of substantial distress ${ }^{89}$ or of

\footnotetext{
${ }^{83}$ Hosking, at [77].

${ }^{84}$ At [125].

${ }^{85}$ Hosking, at [259] "Whether the plaintiff has a reasonable expectation of privacy depends largely on whether publication of the information... would in particular circumstances cause substantial offence to a reasonable person".

${ }^{86}$ At [255]-[256].

${ }^{87}$ NA Moreham "Recognising Privacy in England and New Zealand" (2004) Cambridge Law Journal 555, at 556.

${ }^{88}$ NA Moreham "Why is Privacy Important?" above ch $2 \mathrm{n} 9$, at 246.

${ }^{89}$ John Burrows and Ursula Cheer Media Law in New Zealand (Oxford University Press, New Zealand, 2005) at 177.
} 
humiliation or affront to dignity. ${ }^{90}$ She also highlighted four reasons why the highly offensive test should not be an element of the New Zealand privacy tort. According to her, the highly offensive publicity requirement obfuscates the dignitary nature of privacy interest and encourages the court to examine the wrong issues. It is also be inconsistent with the requirements of other dignitary torts. Therefore, the test should be removed as it is unnecessary and unpredictable. ${ }^{91}$ The English courts also rejected the highly offensive publicity test and developed the action through the reasonable expectation of privacy test and the balancing between privacy and freedom of expression. ${ }^{92}$

This thesis submits that the offensive element should not be included as part of the privacy action. This is because breaches of privacy are about dignity and humiliation, and the highly offensive test obscures the dignitary nature of privacy interests. ${ }^{93}$ Moreover, because the nature of the interest protected by the law of privacy is the protection of dignity and human value, the effect on the claimant of a breach is humiliation and embarrassment and not necessarily offence. ${ }^{94}$ The highly offensive test is therefore inappropriate.

The significant value attached to freedom of expression requires the defendant to prove that the information disclosed is more than a matter of general interest or curiosity. The next section discusses the defence of legitimate public concern.

\section{(c) The defence of legitimate public concern}

The joint judgments in Hosking held that legitimate public concern in cases of interference with privacy should be available as a defence rather than an element of the tort itself. It would be for the defendant to provide the evidence

\footnotetext{
${ }^{90}$ Moreham, above $\mathrm{n} 87$, at 556 .

${ }^{91}$ NA Moreham "Why is Privacy Important?" above ch 2 n 9, at 240-246.

${ }^{92}$ At 246.

${ }^{93}$ At 240

${ }^{94}$ See above ch 2 , at $25-28$.
} 
and to prove that public interest exists. A defence of legitimate public concern would ensure that the scope of privacy protection should not exceed such limits on freedom of expression as is justified in a free and democratic society. ${ }^{95}$ The defence emphasises that the matter be one of legitimate public concern, about which the public needs to know and not enough to be merely of general curiosity. ${ }^{96}$

The onus is on the defendant to establish the defence. The expression used in the judgment is "legitimate public concern" not "public interest". "Public interest" is well-known in defamation and breach of confidence cases and distinct from "public concern". The word "concern" is deliberately used, to distinguish between matters of general interest or curiosity to the public, and matters which are of legitimate public concern. ${ }^{97}$ The greater the infringement of privacy, the greater the public concern needed to override it, and vice versa. ${ }^{98}$ Gault $\mathrm{P}$ and Blanchard $\mathrm{J}$ commented on the defence: ${ }^{99}$

\footnotetext{
The level of legitimate public concern would have to be such as outweighs the level of harm likely to be caused...if the publication was going to cause a major risk of serious physical injury or death, a very considerable level of legitimate public concern would be necessary to establish the defence.
}

If the defendant fails to prove that the publication of plaintiff's private information is a matter of legitimate public concern, then an action in privacy is maintained and the plaintiff entitled to the remedies discussed in the following section.

\footnotetext{
${ }^{95}$ Hosking, at [129]-[130].

${ }^{96}$ At [133]-[134].

${ }^{97}$ At [133].

${ }^{98}$ At [257].

${ }^{99}$ At [134].
} 


\section{(d) Remedies}

The Court of Appeal in Hosking emphasised that the primary remedy for a breach of privacy is damages, but injunctive relief may be appropriate too. ${ }^{100}$ The court concluded that an injuction to restrain publication in the face of an alleged interference with privacy is only available where there is compelling evidence that intended publication of private information is highly offensive and of little legitimate public concern in the information. In most cases, damages would be an adequate remedy. ${ }^{101}$

Tipping $\mathbf{J}$ agreed that damages should be a primary remedy for invasion of privacy. He argued that prior restraint by injunction could be possible only in cases which are both severe in likely effect and clear in likely outcome. He commented: ${ }^{102}$

Freedom of expression values will ordinarily prevail at the interlocutory stage. I am mindful of the chilling effect which potential claims for damages for invasion of privacy might have on the activities of news media organisations and perhaps others. But against that I am mindful too of the considerable distress which unwarranted invasion of privacy can cause. The right to freedom of expression is sometimes cynically invoked in aid of commercial advantage. Of course the right to freedom of expression exists in the commercial field, but it should not be allowed to become a justification for what may be little more than a desire to boost circulation or ratings when that legitimate commercial objective has a substantial adverse impact on the personal dignity and autonomy of individuals and serves no legitimate public function.

\footnotetext{
${ }^{100}$ Hosking, at [149].

${ }^{101}$ Hosking, at [158].

${ }^{102}$ At [258].
} 
Hosking finally confirmed that there is a stand-alone tort of invasion of privacy that in appropriate circumstances covers the publication of private facts. The decision leaves open the question of whether a remedy should be available for unreasonable intrusion into a person's solitude or seclusion. One thing that is clear, is that in New Zealand, an individual, even a celebrity, will in circumstances where the elements of the tort exist, have a cause of action against the media for invasion of privacy.

\section{Development after Hosking}

This section explains how the requirements of the actions have been applied in subsequent cases. Post-Hosking cases are worthy of discussion as they show how the tort has been applied in individual cases and how its requirements are developing. Issues like the scope of the reasonable expectation of privacy, the desirability of the highly offensive test, the limitation on freedom of expression, and the defence of legitimate public concern examined by courts in subsequent cases and are discussed below.

The previous cases and the decision in Hosking itself showed the potential breadth of privacy claims. Since Hosking, there has not been a great deal of case law on the privacy tort. ${ }^{103}$ Burrows claimed that the lack of paradigm privacy cases may be due to the media's attitudes which have not been as intrusive as overseas colleagues in this respect. Another reason is because of the ability to complain to the Press Council, the Broadcasting Standards Authority (BSA) or Online Media Standards Authority (OMSA) which is simple and cheap. ${ }^{104}$

\footnotetext{
${ }^{103}$ Burrows, above n 69 , at 403 .

${ }^{104}$ See s 5 of the Broadcasting Act 1989; see also Privacy Principle I, Broadcasting Standards Authority which provides that "It is inconsistent with an individual's privacy to allow the public disclosure of private facts, where the disclosure is highly offensive to an objective reasonable person".
} 
In Brown v Attorney-General, ${ }^{105}$ the plaintiff had recently been released on parole after serving three-and-a-half years for the kidnapping and indecent assault of a five-year-old boy. Police arrived at the plaintiff's residence and took photographs of him. The photographs were taken with the consent of the plaintiff who believed that they were for police records only. Subsequently, the police circulated a flyer containing the plaintiff's photo and warned locals to be aware of the plaintiff's activities. As a result, the plaintiff received verbal abuse and continued to be the victim of harassment even after he moved from his apartment.

He successfully sued the Attorney-General for damages and was awarded $\$ 25,000$ for invasion of privacy. In this case, the court said that the plaintiff must first establish that the information is such that there is a reasonable expectation of privacy. According to Spear DCJ, the test is simply whether, at the time that the privacy is alleged to have been invaded, there is a reasonable expectation that the relevant information should be considered private. ${ }^{106}$ In other words, what is required is an objective appraisal as to whether, in any particular case, there could reasonably be an expectation that the information was private as against public. ${ }^{107}$

The judge found that the flyer did not comply in several respects with police guidelines on the public naming of persons, and that the flyer was in the circumstances unjustified. The facts demonstrated that the plaintiff could reasonably expect that his likeness and whereabouts would not be published in this way, and that the publicity given to his private facts would be considered highly offensive to an objective reasonable person.

In relation to the "highly offensive test" Tipping $\mathrm{J}$ in Hosking considered that the second element of the tort should probably be part of the considerations as

\footnotetext{
${ }^{105}$ [2006] NZAR 552 (DC).

${ }^{106}$ At [64].

${ }^{107}$ At [65].
} 
to whether there was a reasonable expectation of privacy. ${ }^{108}$ However, Spear J stated that any approach adopted to the highly offensive test did not matter because the outcome was still the same. ${ }^{109}$ There is no doubt that the private information contained in the flyer was made public and it is clear that there was sufficient publicity to warrant the more extensive enquiry that such publicity would be considered "highly offensive to an objective reasonable person". 110

Spear DCJ regarded the second limb of the tort as a threshold over which publicity given to private information must pass before it becomes objectionable. This is in line with the nature of publicity indicated by the majority in Hosking ${ }^{111}$ that:

the concern is with publicity that is truly humiliating and distressful or otherwise harmful to the individual concerned.

There was no doubt that the publication of the conviction in combination with the plaintiff's photograph and address satisfied the "highly offensive" requirement. In relation to this requirement, the judge stated: ${ }^{112}$

The test of course is not for the objective reasonable paedophile but of a reasonable person in the shoes of the person that the publication is about...I am just able to find that an objective reasonable person, standing in the shoes of the plaintiff, should be highly offended by the publication of that information about the plaintiff. That person should find the resultant vilification to be highly alarming and offensive.

\footnotetext{
${ }^{108}$ Hosking at [256]. Tipping J suggested that the question of offensiveness be controlled within the need for there to be a reasonable expectation of privacy.

${ }^{109}$ Brown, at [57].

${ }^{110}$ At [77].

${ }^{111}$ Hosking. at [126].

${ }^{112}$ At [81].
} 
The court, having weighed up all the arguments, concluded that the publication of the flyer and the information contained within it could not be considered of legitimate public concern, and accordingly found that the claim alleging an invasion of privacy was proved.

Brooker v Police ${ }^{113}$ was an appeal against conviction for disorderly behaviour. However the case provides a good illustration of the balance between the right to privacy and freedom of expression. In this case, Mr Brooker had carried out a public protest outside a constable's house on the grounds that the police constable had acted unlawfully towards him when a search warrant of forensic examination of a car for the purposes of a court case was executed at his house. The Supreme Court considered whether a protest unduly impacted on the spatial privacy of the policewoman to whom the protest was directed and whether privacy was therefore a justifiable limitation of the protester's freedom of expression.

The majority overturned the decision of the Court of Appeal and found that the privacy intrusion did not justify a limitation on freedom of expression. Thomas $\mathbf{J}$ in his dissenting judgment stressed that both freedom of expression and privacy should be recognised as fundamental values and weighed one against the other in a manner designed to afford the greatest protection to both. The judge regarded privacy as an existing right which had not been abrogated or restricted by reason only that it was not expressly referred to in the NZBORA. ${ }^{114}$ Thomas J concluded that the value of a resident's seclusion far outweighed the value to be placed on Mr Brooker's exercise of his right to freedom of expression.

The court held that in this case, privacy is a right as fundamental as the right to freedom of expression. However, a peaceful protest or picket which is simply

\footnotetext{
${ }_{113}^{112007]} 3$ NZLR 91 (SC) (Brooker).

${ }^{114}$ At [164].
} 
annoying or embarrassing and does not seriously interfere with use of the neighbourhood by others does not become disorderly simply because it is conducted in a residential street. ${ }^{115}$ There was no suggestion that the messages Mr Brooker was conveying were objectively alarming or threatening. The right to freedom of expression held more weight than the right to privacy in one's home located in a residential neigbourhood and accordingly allowed the appeal.

The majority decision in Brooker can be contrasted with the majority decision of the Court of Appeal in Hosking that the tort of invasion of privacy is a reasonable limit on free expression in terms of s 5 of the Bill of Rights Act in certain circumstances involving the publication of private facts. Tipping $\mathbf{J}$ concluded that in certain circumstances, privacy values could outweigh the right to freedom expression. ${ }^{116}$

Another post-Hosking case is Rogers $v$ Television New Zealand. ${ }^{117}$ This case is important because it clarifies the scope of the tort of privacy and the defence of public interest. Elias CJ accepted that the scope of the tort recognised in Hosking required consideration on a case-by-case and factspecific basis and did not purport to establish the limits of the tort in all circumstances. ${ }^{118}$ Thus, a generalization of the scope of the tort would not resolve issues indirectly relevant to the Hosking facts, such as the questions about proper use of police authority which were involved in Rogers.

In Rogers, a reasonable expectation of privacy arose in relation to a videotaped murder confession made for the police, even though it had been produced for use in a public trial. This was because the plaintiff had given up privacy rights for the trial process but not for all time. Further, the tape would

\footnotetext{
${ }^{115}$ At [47].

${ }^{116}$ Hosking at [237].

${ }^{117}$ [2008] 2 NZLR 277 (SC) (Rogers).

${ }^{118}$ At [23].
} 
have been under the control of the court during that time, and in any event, it had been ruled inadmissible on the grounds that the plaintiff's right had not been properly protected when it was obtained. He was acquitted at trial. TVNZ wanted to show a video of the confession in a documentary to demonstrate a failure of the justice system. Rogers sought an injunction to prevent the broadcast on the ground of privacy. Nevertheless, this privacy interest was held to be minimal compared with that arising from inherently private facts.

The Court of Appeal unanimously allowed the appeal and found that once the confession was held inadmissible, Rogers had a reasonable expectation of privacy in relation to it. However, the Supreme Court disagreed and the majority of the judges were of the view that Rogers must have known that the confession might be given in evidence in open court and thus he should have understood that the public would learn of it. It could not be said that he had a "reasonable expectation of privacy" in relation to it.

One of the issues considered in this case was about the time during which expectations of privacy must be assessed. The court seemed to be of the view that the relevant expectation of privacy must have been present at the time the video was filmed. This approach largely determines the question of expectation because it must have been understood by Mr Rogers that the interview could be admitted in evidence in the public forum of the court. However, the Court of Appeal considered that an expectation of privacy should be assessed at the time the video was ruled inadmissible and concluded, therefore, that there was a reasonable expectation of privacy. ${ }^{119}$ Her Honour also referred to overseas authorities that considered expectations of privacy at the time of proposed publication and concluded that the New Zealand court should resolve this matter so that liability could be determined clearly.

${ }^{119}$ At [26]. 
With regard to the recognition of the privacy tort and its requirement, the court in Rogers considered that Hosking was not the solution for all questions about liability where privacy interests were adversely affected. ${ }^{120}$ In fact the Hosking line of cases only provides an appropriate approach in dealing with wrongful disclosure of private information. The Supreme Court in Rogers confirms that such development should be considered with caution. An issue left for further deliberation was the requirement of "highly offensive publicity", because the test was debated and received much criticism in Campbell. $^{121}$

However, most of the judges noted that the facts in Rogers were very different from those in Hosking and thus, the decision did not really deliberate on significant issues of the nature of privacy tort recognised in Hosking. McGrath J stated that: ${ }^{122}$

\begin{abstract}
It is unnecessary for this Court to give any detailed consideration to the Court of Appeal's decision in Hosking $v$ Runting in this case. Accepting for present purposes... that there is a privacy tort, the limits which are stated in the judgments of a majority of the Court of Appeal in that case, it is plain that the circumstances of Mr Rogers's case do not establish the private nature of the factual information which he seeks to protect his claim.
\end{abstract}

In exceptional circumstances, a reasonable expectation of privacy can arise even though the facts have been recorded in public place as illustrated in Andrews $v$ Television New Zealand Ltd. ${ }^{123} \mathrm{Mr}$ and Mrs Andrews were injured in a car accident. TVNZ filmed Mr Andrews being carried from the wrecked car on the side of the road, with his wife beside him. A private conversation

\footnotetext{
${ }^{120}$ At [26].

${ }^{121}$ At [25].

${ }^{122}$ At [99].

${ }^{123}$ [2009]1 NZLR 220 (HC) (Andrews); Hosking at [164], see also Cheer, above n 79, at 176177.
} 
between the husband and wife was recorded and broadcast on a documentary about the work of the fire service.

The plaintiffs claimed that the conversation and the scenes broadcast in the defendant's television programme gave rise to a reasonable expectation of privacy. They contended that they were unaware that they were filmed or that Mrs Andrews' conversation would be recorded and published. The couple also pleaded that the broadcast was highly offensive to them and to an objective reasonable person. It was alleged that they suffered substantial humiliation, pain and suffering and sought general and punitive damages. ${ }^{124}$

The defendants denied the claim and contended that the plaintiffs were not identifiable to the general public in the broadcast, and pleaded specifically that the scenes and conversations broadcast all occurred in a public place. Thus, there was no reasonable expectation of privacy in the conversations and scenes relied upon by the plaintiffs and the broadcast would not be considered highly offensive by an objective reasonable person. They added that in fact the broadcast was related to a matter of legitimate public concern and was, therefore, in the public interest. ${ }^{125}$

Allan $\mathbf{J}$ was of the view that there was no right to privacy because the accident and the circumstances surrounding it occurred in public. However, His Honour stated that the communications between plaintiffs were private and intimate and of an altogether more personal nature than the information involved in Hosking. ${ }^{126}$ Thus, the plaintiffs were reasonably entitled to expect that their conversation would not be heard beyond those within earshot. ${ }^{127}$ Allan $\mathbf{J}$ held that although everything had taken place in public, the couple

\footnotetext{
${ }^{124}$ At [19].

${ }^{125}$ At [20].

${ }^{126}$ At [65].

${ }^{127}$ At [66].
} 
nonetheless had a reasonable expectation of privacy of their conversation. He said: ${ }^{128}$

I accept however that an expectation of privacy otherwise reasonable may in certain circumstances be lost by reason of culpability on the part of the plaintiff. It is to be observed that the same consideration might well arise in a given case in the course of an assessment of whether the publication of private facts is highly offensive and further in relation to the assessment of a defence of legitimate public concern.

However, the Andrews were denied a remedy because what was published could not be said to be "highly offensive". Allan J referred to the second limb in Hosking and concluded that although the conversations were of intimate and highly personal character, they were not humiliating and embarrassing because there was no reference whatever in the programme to the precise cause of the accident, and no mention of the fact that the driver of the vehicle was intoxicated. ${ }^{129}$ Mrs Andrews herself acknowledged that nothing she said to her husband could be regarded as humiliating or embarrassing to either of them. Thus, the plaintiffs failed to satisfy the "highly offensive" test, and accordingly the claim failed.

The pre- and post-Hosking cases show that the new tort is a very useful cause of action in cases involving invasion of privacy. It is the responsibility of the court to shape the common law for future development of privacy law. The court in Hosking held that statutes also have their role to lay down firm and detailed rules and to predict more potential problems. ${ }^{130}$ However, the inherent need for the development of the law through courts' activities has

\footnotetext{
128 At [47].

${ }^{129}$ At [67].

${ }^{130}$ Hosking at [33], Keith J at [202-207].
} 
proved to be a better vehicle than a legislative approach in matters concerning private life, such as privacy.

New Zealand's development of privacy law has demonstrated that a legal framework of privacy law is still developing and needs to be constantly scrutinised to protect freedom of expression. The tort formulated in Hosking has brought a new dimension for the development of privacy law as a preferable alternative to a breach of confidence action as a means of protecting privacy interests in New Zealand.

As for the new tort, Burrows commented that it is a common law tort and therefore has flexibility which is the major strength of the common law. But it also possesses that common law's disadvantages: uncertainty of scope and incompleteness. ${ }^{131}$ This comment conforms to Anderson $\mathrm{J}$ in the Supreme Court who is in agreement with Elias CJ, who states in Rogers: ${ }^{132}$

As to the issue of breach of privacy I will assume, without wishing to be taken as endorsing it, the law as elucidated by the majority of the Court of appeal in Hosking $v$ Runting. I share the concern expressed by the Chief Justice that the jurisprudence of Hosking should not be regarded as settled. It was decided by a bare majority and both the existence of the tort and the scope of it, if it continues to be recognised, will fall to be reviewed by this Court in an appropriate case.

The Hosking case did create a tort of public disclosure of private facts. Despite its ambiguity in nature and scope as commented on in Rogers, it has provided a remedy for persons whose private facts are published in a highly offensive manner and when the defence of legitimate public concern does not

\footnotetext{
${ }^{131}$ John Burrows "Invasion of Privacy" in Stephen Todd (ed) The Law of Torts in New Zealand (6th ed, Thomson Reuters, Wellington, 2013) at 983.

${ }^{132}$ Rogers, at [144].
} 
outweigh their publication. The disclosure tort has no application to intrusion. However, an incremental extension of the tort can be seen in the High Court case analysed in the following discussion. ${ }^{133}$

\section{Protection against Intrusion}

This Part discusses relevant statutory law for the protection against intrusion and the new category tort of intrusion into solitude or seclusion and private affairs emerged from Holland.

\section{A Legislation and Case Law}

This section addresses the legislative context of the protection against intrusion tort. Such protection could be sought from harassment law, criminal law and also laws relating to search and surveillance.

The Harassment Act 1997 introduces both civil and criminal penalties for a pattern of conduct such as watching another person's residence, entering a person's property, or making contact with a person by telephone, correspondence, or in any other way. It is also an offence to covertly film someone in an intimate situation. Section 3 defines "harassment":

For the purpose of this Act, a person harasses another person if he or she engages in a pattern of behaviour that is directed against that other person, being a pattern of behaviour that includes doing any specified act to the other person on at least two separate occasions within a period of 12 months.

\footnotetext{
${ }^{133}$ C v Holland [2012] 3 NZLR 672 (Holland).
} 
The definition sets out the key feature of a harassment claim: that the complainant must establish a pattern of behaviour directed at a person and it was not actionable for a single incident. The specified acts must have occurred on at least two separate occasions within a period of 12 months. The Act lists specified acts that amount to harassment such as watching, loitering near or preventing or hindering access to or from, that person's place of residence, business, employment, or any other place frequented by the person for any purpose. $^{134}$

The nature of the specified acts is in essence privacy interferences into the physical space and bodily integrity of the victim which clearly interfere with the comfort and enjoyment of an individual to lead his or her life free from unwanted access. The Act does, to a certain extent provides protection against intrusion in circumstances where a person is continually followed, watched at and listened to. However, the Act has no application to the wrongful publication of private information. It also only applies if the act occurs more than once.

Part 9A of the Crimes Act 1961 under the heading of "Crimes against personal privacy" provides protection against unauthorised interception, unlawful disclosure of private information and unauthorised intrusions into intimate personal spaces. Section $216 \mathrm{H}$ prohibits the making of intimate visual recording. It prescribes punishment for a term not exceeding three years imprisonment for those who intentionally or recklessly make an intimate visual recording of another person. Section $216 \mathrm{G}$ defines intimate visual

\footnotetext{
${ }^{134}$ Section 4 Harassment Act 1997 provides "(1) For the purposes of this Act, a specified act, in relation to a person, means any of the following acts:(a) watching, loitering near, or preventing or hindering access to or from, that person's place of residence, business, employment, or any other place that the person frequents for any purpose: (b) following, stopping, or accosting that person: (c) entering, or interfering with, property in that person's possession: (d) making contact with that person (whether by telephone, correspondence, or in any other way): (e) giving offensive material to that person, or leaving it where it will be found by, given to, or brought to the attention of, that person: (f) acting in any other way(i) that causes that person (person A) to fear for his or her safety; and (ii) that would cause a reasonable person in person A's particular circumstances to fear for his or her safety."
} 
recording as "a visual recording that is made in any medium using any device without the knowledge or consent of the person who is the subject of the recording". 135

Section 46 of the Search and Surveillance Act 2012 also affirms freedom against intrusion. It states:

(1) Except as provided in s 47 and 48 , an enforcement officer who wishes to undertake any 1 or more of the following activities must obtain a surveillance device warrant (c) observation of private activity in private premises, and any recording of that observation, by means of a visual surveillance device;

The right of an individual to have enjoyment of the land is part of freedom from intrusion. Section 38 of the Residential Tenancies Act 1986 provides:

(1) The tenant shall be entitled to have quiet enjoyment of the premises without interruption by the landlord or any person claiming by, through, or under the landlord or having superior title to that of the landlord.

(2) The landlord shall not cause or permit any interference with the reasonable peace, comfort, or privacy of the tenant in the use of the premises by the tenant.

(3) Contravention of subsection (2) of this section in circumstances that amount to harassment of the tenant is hereby declared to be unlawful act.

(4) In this section premises include facilities.

The intrusion legislation discussed above can, therefore, be used to protect against unwanted photography, spying, following, filming, bugging, searching and other interferences with a person's physical privacy. They seem to offer

\footnotetext{
${ }^{135}$ Section 216G (1)-(2).
} 
adequate protections against physical intrusion defined in this thesis. Similar protections have also been provided under the criminal law in Malaysia as discussed in Chapter Four although they are not as comprehensive as what have been offered under the New Zealand law. However, the acknowledgment of the seriousness of the offence under the criminal law suggests that such interference should be part of a civil tort, so to enable a victim to claim for compensation against the perpetrator. This justifies the inclusion of the unwanted access to the physical body or space of an individual to be an aspect of privacy protection under the Bill.

The Broadcasting Standards Authority's Privacy Principles recognise claims of intrusion against an interest in solitude or seclusion where material has been publicly disclosed. Principle 3 provides that:

(a) It is inconsistent with an individual's privacy to allow the public disclosure of material obtained by intentionally interfering, in the nature of prying, with that individual's interest in solitude or seclusion. The intrusion must be highly offensive to an objective reasonable person. (b) In general, an individual's interest in solitude or seclusion does not prohibit recording, filming or photographing that individual in a public place ('the public place exemption'). (c) The public place exemption does not apply when the individual whose privacy has allegedly been infringed was particularly vulnerable, and where the disclosure is highly offensive to an objective reasonable person.

An analysis of intrusion law in New Zealand has been made by Whata $\mathrm{J}$ in $C v$ Holland. ${ }^{136}$ His Honour held that the leading judgment on the concept of intrusion related to privacy is $R v$ Williams $^{137}$ where the Court of Appeal stated:

\footnotetext{
${ }^{136}$ Above n 6.

${ }^{137}$ [2007] NZCA 52, [2007] 3 NZLR 207 (CA) at [48]. See Holland at [25].
} 
A touchstone of s 21 of the Bill of Rights is the protection of reasonable expectations of privacy. It is thus only where a person's privacy interest has been breached that his or her rights under s 21 have been breached and a personal remedy is available.

The Court said that s 21 provided protection of the rights of the general public. Privacy interests in premises should thus be assessed objectively without any concentration on property rights, or the activities of the accused. ${ }^{138}$ His Honour accepted the value of freedom from unwanted intrusion into private spheres and that was emphasised in Brooker v Police. ${ }^{139}$ McGrath J said:

Privacy is an "an aspect of human autonomy and dignity". Although, as a police constable, the complainant is a public official, in her private life she is entitled to enjoyment of the rights of an ordinary citizen. Her privacy interest in the present appeal is her right to be free from unwanted physical intrusion into the privacy of her home.

The above discussion acknowledges that the concept of privacy has been dealt with extensively in New Zealand law and some legislation provides sanctions and protections against intrusion.

\section{B The Tort of Intrusion upon Seclusion: C v Holland}

In August 2012, the High Court in $C v$ Holland held that a tort of intrusion upon seclusion is part of New Zealand law. This development expanded the Hosking tort to provide protection to spatial privacy. It protects individuals from unauthorised intrusion into personal space or seclusion. The judge commented on the lack of authority in New Zealand for the proposition that

\footnotetext{
${ }^{138}$ At [63].

${ }^{139}$ [2007] NZSC 30; [2007] 3 NZLR 91 at [193]. See Holland at [27]. However, it is important to note that both Williams and Brooker were not tort cases.
} 
an intrusion upon an individual's seclusion in breach of a reasonable expectation of privacy gives rise to an actionable tort in New Zealand. ${ }^{140}$ The post-Hosking cases have not given any indication as to whether the Hosking privacy tort would be applicable in cases of unreasonable intrusion and where no publication of private information is involved.

$C v$ Holland involved a surreptitious installation of a recording device in the roof cavity above a bathroom. In that case, a $\mathrm{C}$ lived in the house owned by her boyfriend and the defendant, Mr Holland. The defendant recorded two separate video clips of $\mathrm{C}$ undressing and showering using a hidden small camera in the roof cavity. The videos were not published but the defendant did download them onto an external hard drive. $\mathrm{C}$ and her boyfriend subsequently discovered the recordings. C did not consent to the defendant's act of watching her in the shower or taking the video clips. She was extremely distressed and made a police report. Holland was charged under s $216 \mathrm{H}$ of the Crimes Act 1961 and pleaded guilty to the criminal charge of making an intimate visual recording. He was ordered to pay $\$ 1,000$ in emotional harm reparation and discharged without penalty. $\mathrm{C}$ then commenced an action for breach of privacy to recover damages. The issue was whether the Hosking tort could provide a remedy to the present case where no publication was involved.

On the facts, Whata $\mathbf{J}$ found that an intrusion into $\mathrm{C}$ 's solitude and seclusion had occurred when the defendant successfully recorded $\mathrm{C}$ in the bathroom partially undressed or naked. The conduct was highly offensive to a reasonable person and thus, infringed C's reasonable expectation of

\footnotetext{
${ }^{140}$ Holland, at [8]. The judge also referred to New Zealand Law Commission Invasion of Privacy: Penalties and Remedies: Review of the Law of Privacy Stage 3 (NZLC R 113, 2010) at 92-93. See also Stephen Penk "Future Directions and Issues" in Stephen Penk and Rosemary Tobin (eds) Privacy Law in New Zealand (Brookers, Wellington, 2010) at 15.5.4.
} 
privacy. ${ }^{141}$ The central issue to be determined by the court was whether a tort of intrusion upon seclusion should form part of the law of New Zealand. ${ }^{142}$

Counsel for the defendant advanced three key objections to the transformation of privacy values into actionable rights at common law: ${ }^{143}$

(a) Privacy per se is not justiciable;

(b) It is for Parliament, not the Judiciary to resolve the weight to be accorded to privacy as a value within a complex matrix of competing values, interests and rights;

(c) A privacy tort is not necessary.

However, His Honour strongly believed that the objections did not prevent the recognition of a tort of intrusion upon seclusion in New Zealand law. Privacy is a value worth protecting and linked to personal autonomy. When addressing the first objection, the judge accepted that a general claim to privacy may not be conformable to the rules of law or be transformed into a rule of law thus giving rise to an actionable claim. Based on the development since Hosking, the transformation of aspects of privacy into rights and unwanted intrusion into a wrong was already in place and judges were capable of adjudicating on the content and boundaries of a privacy right to be free from intrusion upon seclusion. ${ }^{144}$

His Honour gave six reasons to support this conclusion. Firstly, the existing rules that regulate intrusion into personal affairs as both a civil and criminal wrong affirmed the status of freedom from intrusion into personal affairs as a recognised value in New Zealand. Secondly, the freedom was in conformity with justified limitations including a defence of legitimate public concern.

\footnotetext{
${ }^{141}$ Holland, at [6] and [7].

${ }^{142}$ At [5].

${ }^{143}$ At [65].

${ }^{144}$ At [74].
} 
Thirdly, a tort of intrusion upon seclusion was entirely compatible with, and a logical adjunct to the Hosking tort of unauthorised publication of private facts because the same underlying wrong of unwanted intrusion into a reasonable expectation of privacy was at issue in both types of cases. Fourthly, freedom of speech affirmed by s 14 of the NZBORA was only infringed when publication was also contemplated. Fifthly, there were similarities in structure between the intrusion tort and the traditional tort based on protection of property and the person which involve unwanted acts causing harm to a person's possession or to the person. Sixthly, common law has the capacity to adapt in the light of a changing social context. ${ }^{145}$

Having scrutinised the existing laws, the court found that the existing protections from intentional intrusion into personal space were coherent but not comprehensive. In the absence of publication, the Hosking privacy tort had no direct application to the facts in Holland. ${ }^{146}$ In fact, the role of breach of confidence was far from clear in intrusion cases. Moreover, an action based on intentional infliction of emotional distress was unlikely to succeed as shown by Wainwright. A criminal sanction was triggered, but that relied somewhat fortuitously on the specific facts fitting the statutory criteria. ${ }^{147}$

In holding that a tort of intrusion upon seclusion is part of New Zealand law, ${ }^{148}$ and taking into consideration the consistency with the North America tort and domestic privacy law and principles, Whata $\mathbf{J}$ held that in order to establish a claim based on the tort of intrusion upon seclusion a plaintiff must show: ${ }^{149}$

(a) An intrusion must be intentional and unauthorised one,

(b) Into seclusion (namely intimate personal activity, space or affairs),

\footnotetext{
${ }^{145}$ At [75].

${ }^{146}$ At [89].

${ }^{147}$ At [89].

${ }^{148}$ At [93].

${ }^{149}$ At [94].
} 
(c) Involving infringement of a reasonable expectation of privacy,

(d) That is highly offensive to a reasonable person.

His Honour described "intentional act" to mean an affirmative act, not an unwitting or simply careless intrusions. "Unauthorised" excluded consensual and/or lawfully authorised intrusions. ${ }^{150}$ Thus, an intrusion that is reckless or negligent will not satisfy the requirement. The reference to intimate personal activity in the second element acknowledges the need to establish intrusion into matters that most directly impinge on personal autonomy. ${ }^{151}$

The third and fourth elements resemble the Hosking requirements and remain in harmony with the existing privacy tort in New Zealand. Both torts share a similar aim of protection, in which the disclosure tort protects plaintiffs from humiliation and distress caused by publication of embarrassing private information, ${ }^{152}$ and the intrusion tort arises in respect of an intrusion that is objectively determined, due to its extent and nature, to be offensive by causing real hurt or harm. A legitimate public concern for the information may provide a defence to the privacy claim. ${ }^{153}$

When commenting on the test of reasonable expectation of privacy, Whata $\mathbf{J}$ did not agree with the plaintiff's counsel who suggested a simple reasonable expectation of privacy in intrusion cases. His Honour stated: ${ }^{154}$

In my view however, a one-step reasonable expectation of privacy test comparable to the art 8 test applied in the United Kingdom for breach of confidence is not sufficiently prescriptive. The capacity for conflict between the right to seclusion and other rights and freedom is very significant. This

\footnotetext{
${ }^{150}$ At [95].

${ }^{151}$ At [95].

${ }^{152}$ See Hosking, at [126], [128] and [138].

${ }^{153}$ Holland, at [96].

${ }^{154}$ At [97].
} 
demands a clear boundary for judicial intervention. Furthermore, a highly offensive test will also set a workable barrier to the unduly sensitive litigant that seemed to trouble Lord Hoffmann in Wainwright.

The court in Holland concluded that an action for intrusion is part of the law of New Zealand. Thus, Mr Holland intruded into C's intimate personal space and activity when he videoed her in the shower without her consent and without legislative authority. The intrusion infringed a reasonable expectation of privacy and was highly offensive to the reasonable person. $\mathrm{C}$ was entitled to damages.

\section{Conclusion}

The protection of privacy interests in New Zealand is developing fast. The fact that there is no general right to privacy in the New Zealand Bill of Rights Act 1990 is not a barrier to courts identifying and recognising the emergence of a common law tort of breach of privacy. As long as the s 5 conditions of a reasonable limitation demonstrably justified in a democratic society are met, the court is free to develop the law to protect legitimate claims to privacy.

Unlike the position in the UK, the New Zealand law of privacy began with the premise that a tort of invasion of privacy existed. ${ }^{155}$ The refusal to affirm the tort by Randerson $\mathrm{J}$ in Hosking ${ }^{156}$ did not survive after the Court of Appeal confirmed that a new tort of invasion of privacy existed in New Zealand. Gault $\mathrm{P}$ and Blanchard $\mathrm{J}$ preferred to articulate a distinct tort rather than rely on a claim for breach of confidence. ${ }^{157}$ The shortcomings of New Zealand's

\footnotetext{
${ }^{155}$ See Tucker [1986], Bradley [1993], $P$ v D [2000], and $L v G$ [2002]. ${ }^{156}$ [2003] 3 NZLR 285 (HC).

${ }^{157}$ At [46], Their Honours observed that privacy cases do not fit within a breach of confidence action which requires information to be confidential, communication of that information to another in circumstances importing an obligation of confidence and unauthorised use or disclosure.
} 
privacy tort formulated in Hosking can be seen from the terminology used for the tort itself. It deals only with the "public" disclosure of "private" facts. It does not cover invasions of privacy by intrusions where no information is published.

It is not surprising that the Court of Appeal in Hosking did not decide whether a tortious remedy should be available for unreasonable intrusion into solitude or seclusion. The concern of the court at the time was to recognise the existence of a privacy tort as identified by Prosser and developed in US cases. The boundaries of a cause of action cannot be ascertained in a single decision and thus will evolve through future decisions as Courts assess the nature and impact of particular circumstances. ${ }^{158}$

In fact, the Law Commission Report had recommended that development under the common law should continue on the basis that the common law itself has the great advantage to tackle fact specific privacy issues in a fastmoving area of law and that the judges can make informed decisions on actual cases as they arise. Furthermore, the flexibility of the common law suggests that it will develop with the times. The report also thought that the number of cases on privacy would be unlikely to increase with the enactment of the statute, and thus it will be of little use and not worth enacting it as such. ${ }^{159}$ This thesis agrees that the reasons are acceptable and strong for New Zealand which has a clearly-established tort at common law, but not for Malaysia which is now at the very early development of privacy law.

The Court, however expressed the view that the introduction of any high level and wide tort of invasion of privacy should be a matter for the legislature. ${ }^{160}$ Their Honours held that the development of a privacy tort is best achieved through specific legislation. However, judicial intervention a few years later

\footnotetext{
${ }^{158}$ Hosking at [118].

${ }^{159}$ New Zealand Law Commission Report, above n 140, at 90-91.

${ }^{160}$ Hosking, at [110].
} 
in Holland opened a new dimension and broadened the scope of privacy protection of information to cover intrusion as well. The position is now that if the photos have not been published, an action is maintained under the new tort, and if it involved publication, the Hosking tort could provide remedy for the breach. These developments complement each other and offer a comprehensive protection of privacy in New Zealand.

These significant developments in the area of privacy law provide a good example for Malaysia in developing a privacy tort, and at the same time, acknowledge the importance of the existence of a statutory tort of privacy. Matters such as the characteristics of the privacy tort, its tests, defence, remedies and balancing exercise are fundamental considerations for the development of a good privacy law. However, as discussed earlier in this chapter, not all features of the New Zealand privacy tort will be applied in the proposed statutory tort. The Bill excludes the highly offensive test for the reasons discussed previously and instead relies solely on the reasonable expectation of privacy test. As regards to defence in privacy action, the Bill uses public interest defence because "legitimate public concern" is not a phrase used in Malaysia. New Zealand law provides useful guidance for lawmakers in Malaysia on these matters. The following chapter examines the proposed law for Malaysia. 


\section{PART IV: PROPOSAL}

\section{CHAPTER SEVEN}

\section{A PRIVACY LAW FOR MALAYSIA}

\section{Overview}

Having discussed the development of privacy law and the structure of the legal protection provided in England and New Zealand, this thesis suggests that Malaysia should have a statute on privacy. The Personal Data Protection Act which applies to the handling and processing of personal data in commercial transactions does not provide protection for individuals whose personal information has been published or intrusion into physical body or space. Thus, the thesis recommended a statute that covers other aspects of privacy protection that are currently unprotected in the Malaysian legal framework. Although neither England nor New Zealand has pursued the statutory path apart from their data protection legislation which protects only against specific types of privacy interference, the current state of privacy protection in both jurisdictions and its incremental development informs the likely nature and scope of privacy law for Malaysia.

The preceding chapters revealed that the protection of privacy may take several forms. First, the extension of breach of confidence action to provide protection for the wrongful use of private information. ${ }^{1}$ Second, the recognition of a separate cause of action for invasion of privacy. ${ }^{2}$ Third, the establishment or recognition of a constitutional right to privacy, ${ }^{3}$ and fourth,

\footnotetext{
${ }^{1}$ This development can be seen in Douglas, A v B plc and Campbell.

${ }^{2} \mathrm{An}$ independent tort of invasion of privacy was created in Hosking and the tort of intrusion upon seclusion was confirmed by Whata $\mathrm{J}$ in Holland.

${ }^{3}$ The right to privacy in India was established by the Supreme Court when dealing with arts 19 and 21 of the Indian Constitution. In Kharak Singh v State of UP \& Ors [1963] AIR 1295, the court recognised that there was a right to privacy implicit in the Constitution under art 21. The same development was followed in Sivarasa.
} 
specific legislation for privacy. ${ }^{4}$ These routes have all been used by various countries in the development of the protection for privacy.

The courts in the United Kingdom preferred to absorb any cause of action in privacy into the doctrine of confidentiality and to utilise an existing principle rather than create a new limb of law. The establishment of the new methodology adopted from the doctrine of breach of confidence to extend protection for privacy actions proved the unwillingness of the UK Parliament to introduce a statutory privacy tort. On the other hand, the New Zealand Court of Appeal recognised a separate tort of privacy.

The establishment or recognition of a constitutional right to privacy and specific legislation for privacy are not new approaches but will continue to grow and be adopted by various jurisdictions in their journey to provide adequate protection for breach of privacy. Although none of the countries of the courts that proposed a statutory tort of privacy have actually done so, they have at least suggested an alternative approach for the development of privacy law.

This chapter discusses the proposed law for privacy in Malaysia. ${ }^{5}$ It provides detailed explanation of the Bill. Part I reviews the shape of privacy protection

\footnotetext{
${ }^{4}$ The courts in other jurisdictions agree that legislation is the best approach to dealing with breach of privacy. For example in Kaye at [66] Glidewell LJ said that "It is well-known that in English law there is no right to privacy, and accordingly there is no right of action for breach of a person's privacy. The facts of the present case are a graphic illustration of the desirability of Parliament considering whether and in what circumstances statutory provision can be made to protect the privacy of individuals". See also Hosking (HC) at [118], Randerson J concluded that New Zealand courts should not recognise a tort that would provide a remedy for the public disclosure of photographs of children taken while they were in a public place for five broad reasons and one of them was "to the extent there might have been gaps in privacy law, they should be filled by the legislature, not the Courts". A statutory tort of privacy has been developed in Ireland (Privacy Bill 2006) and some states of Australia. See Australian Law Reform Commission, Report 108: For Your Information: Australian Privacy Law and Practice (2008), New South Wales Law Reform Commission, Report 120: Invasion of Privacy (2009) and Victorian Law Reform Commission, Surveillance in Public Places: Final Report 18 (2010).
} 
in certain jurisdictions. Part II emphasises the importance of privacy legislation as an appropriate means of protecting privacy. Part III explains all provisions of the Bill and presents comments and discussion in support of the statutory cause of action. Part IV briefly summarises the discussion of this chapter.

\section{Need for a Bill}

The common law of privacy is continually developing to supplement gaps providing protection, but legislation is generally identified as the preferable form of privacy protection. ${ }^{6}$

In the words of Gault P: ${ }^{7}$

The Courts are at pains to ensure that any decision extending the law to address a particular case is consistent with general legal principle and with public policy and represents a step that it is appropriate for the Courts to take. In the last respect there are matters that involve significant policy issues that are considered best left for the Legislature.

\footnotetext{
${ }^{5}$ See the proposed privacy law for Malaysia in the Appendix, at 302. For the purpose of consistency, the thesis uses "Bill", "section" and "subsection" when referring to the proposed law and the provisions in the Privacy Bill 2014.

"See also John Burrows "The News Media and the Law" (2003) 9 Canterbury Law Review 229, at 238; Tucker v News Media Ownership Ltd [1986] 2 NZLR 716 at 733; Greg Taylor and David Wright "Australian Broadcasting Corporation v Lenah Game Meats: Privacy, Injunctions and Possums: An Analysis of the High Court's Decision" (2002) 26 Melbourne University LR 702, at 711; Greg Taylor "Why is there no Common Law Right of Privacy?" (2000) 26 Monash University LR 235, at 269.

${ }^{7}$ Hosking, at [5]. Earlier in Tucker $v$ News Media Ownership Ltd [1986] 2 NZLR 716 at 733 (HC), McGechan J supported the introduction of a common law or tort covering invasion of personal privacy at least by public disclosure of private facts and the boundaries and exceptions of the tort will need much working out on a case by case basis so as to suit the conditions of this country. He said that if the legislature intervenes during the process, so much the better.
} 
In Douglas v Hello! Ltd, Lindsay J, when declining to hold that a general tort of privacy exists in England, felt that the development of a free-standing tort in an area as broad as privacy should be left to Parliament. ${ }^{8}$

The New Zealand Law Commission Report considered the question of whether the privacy tort should be enacted in statutory form. Although the Report ultimately recommended that protection of privacy be left to the common law as discussed above in Chapter Six, the Commission acknowledged that a statute would render the law more accessible than the common law, fill some of the gaps in the current law, and render some of the criteria more certain than they currently are. ${ }^{9}$ This is because the common law is dependent on the accidents of litigation and develops slowly. In this regard, statute law can present a complete and coherent whole straight away. ${ }^{10}$ It is suggested that these arguments are particularly compelling in the Malaysian context because as discussed in Chapters Three and Four, Malaysia lacks of laws protecting aspect of privacy interests and what more of a clearly established privacy tort. Due to the nature and different interests of local inhabitants, it is also hard for Malaysia to simply rely on the adoption of developments on privacy law from the US and the UK.

Having identified the lack of protection afforded to privacy in Malaysia, it is no longer acceptable that people have no appropriate remedies under existing laws against infringements of their territorial or bodily privacy or the privacy of communications. The current developments in favour of privacy protection in the Malaysian courts are as yet fragile and embryonic, thus the need for a statutory cause of action to build on the common law trend.

\footnotetext{
${ }^{8}$ Douglas v Hello! Ltd [2003] 3 All ER 996 at [229].

${ }^{9}$ New Zealand Law Commission Invasion of Privacy: Penalties and Remedies: Review of the Law of Privacy Stage 3 (NZLC R 113, 2010) at 90.

${ }^{10}$ At 90 . However, after careful deliberation, the Law Commission has decided that the tort should be left to develop at common law.
} 
This study has concluded that the introduction of a statutory cause of action for breach of privacy would provide a comprehensive protection and remedies for claimants in privacy actions. A specific privacy law is justified owing to its absence both in the common law and the Constitution of Malaysia. Such a law would clearly establish privacy as an important human right that warrants specific recognition. The law would also make it easier to respond to emerging breaches of privacy and provide clearer guidance to both the media and the public as to their precise rights and obligations. Furthermore, the Bill will remain compliant with the constitutional basis of the right to life and personal liberty defined in art 5 of the Constitution.

Legislative protection is desirable. It would establish a general right to privacy and define a tort of privacy to cover conduct which includes:

(a) collecting, publishing or disclosing private information or embarrassing personal material without consent;

(ii) searching private space, violating the peace of another by intruding upon him or her, or persistently communicating with him or her or intercepting the communication.

It seems that the best way of defining the elements of the new tort would be to use the features highlighted in the United Kingdom and New Zealand case law. This could be done by developing the breach of confidence action which excludes its constraints and reflects generally held views as to the limits of the word "private". One approach would be to define the tort of invasion of privacy on the basis of three elements: (1) unwanted access; (2) into a person's life or personal information; (3) unreasonableness in all circumstances.

The first element of unwanted access may include observation, recording or surveillance by the defendant of the claimant. Matters such as photography, films, tape recording and visual or aural observation are also included. 
Secondly, the tort may involve publication of information about the claimant, such as factual information (whether true or false), photographs, films or recordings (whether actually or purportedly recording the claimant). Thirdly, a breach may entitle an individual to protection to the extent that it is reasonable in all circumstances having regard to the rights of others and general interest of the public.

The introduction of the Bill would constitute the first legislative attempt in Malaysia to protect a general right to privacy. The establishment of this right would potentially fill the gaps in the common law of Malaysia. It would focus on the protection of personal privacy as opposed to the protection of specific personal data provided under the PDPA 2010. The Bill is based on the common law development of privacy in the United Kingdom and New Zealand. Guidelines and references from international documents such as the ECHR, the ICCPR, and Political Rights and Recommendations from Australia $^{11}$ and Ireland ${ }^{12}$ were also referred to in preparing the draft Bill. These comparisons and references confirm the importance of a specific law on privacy.

The proposed Privacy Bill 2014 ("the Bill") establishes and recognises a general right to privacy in Malaysia's legal framework. It provides protection for an individual's privacy and thereby safeguards the interests of all individuals. The law would be directly applied to determine whether the breach has taken place by referring to the requirements set up in the Bill. This would provide a straightforward solution to cases involving invasion of privacy as discussed in Chapter One.

\footnotetext{
${ }^{11}$ See Australian Law Reform Commission, New South Wales Law Reform Commission, and Victorian Law Reform Commission, above $\mathrm{n} 4$.

${ }^{12}$ See Privacy Bill 2006 at http://www.oireachtas.ie/documents/bills28/bills/2006/4406/b4406s.pdf.
} 
The Bill also provides clear rules not only for determining a breach of privacy but also in related matters such as the balancing of rights, remedies and defences. With this Bill, inadequacies of privacy protection could be resolved.

\section{Explanation of the Bill's provisions}

The Bill addresses matters relating to privacy and complements the partial protections currently available in Malaysian law. According to s 13 of the Interpretation Act 1967, every Act shall be a public Act unless the contrary is expressly provided therein. Thus, the Bill can be invoked in cases of breach between individuals or between individuals and public and private bodies. Public bodies include the Federal and State Governments. The application of the Bill is wider than the Personal Data Protection Act 2010 which has no application to Federal and State Governments. In order to achieve the purpose of this Bill and to provide a comprehensive protection, the Bill has universal application and includes the following key features.

Section 3 specifies the purpose of the Bill: To provide for the protection and respect of the dignity of every individual in their private and public lives both in terms of personal information and freedom from physical intrusion. As discussed in Chapter 2, privacy is a basic human need underlying the fundamental value of dignity and honour which exist in a democratic society. The existence of the Bill relates to these values and the protection it offers covers both aspects of privacy, namely protection of personal information and physical intrusion. The Bill establishes a general right to privacy and promotes the protection of that right. It recognises the non-absoluteness of the right and provides a framework for balancing the right with other human rights and public interests. The Bill allows redress.

Common law has long hesitated to recognise an actionable tort of privacy; there has been much judicial debate on the subject. The introduction of the 
Bill will provide a statute-based cause of action for individuals whose privacy has been breached. The doubts and hesitancy of the common law will be superseded.

The following sections analyse all provisions of the Bill.

\section{A Interpretation}

Part I of the Bill deals with preliminary matters. Section 1 concerns the Bill. Its title is chosen to emphasise exclusive protection to cases involving breach of privacy offered by the Bill and is expressly privacy-driven legislation. ${ }^{13}$

Section 2 is a standard provision defining expressions used in the Bill. One of the situations where a breach of the right to privacy takes place is when there is a disclosure. To "disclose" means to make information and other material concerning an individual known to the public or a section of the public or just one person. In a breach of privacy action, the type, manner and extent of disclosure are factors taken into consideration in determining the breach.

"Individual" in the Bill refers to a living person. The Bill has nothing to do with disclosure of information relating to dead persons or to corporate entities. As discussed earlier in Chapter Two, privacy is a dignitary interest, thus it cannot apply to corporations and even more difficult to apply to dead persons. Although we should not dishonour the dead, the interest that are protecting there might not be a privacy one.

"Interference" with an individual's life results in a breach. It is the action of interfering, or actions taken which lead to interference. It covers both the act and the process carried out before interference takes place. Thus, if a person

\footnotetext{
${ }^{13}$ By comparison, the same name is used in New Zealand (the Privacy Act 1993) for the legislation protecting an aspect of individual privacy namely information privacy.
} 
installs a CCTV in a bedroom in order to capture images of other individuals, the breach takes place when the CCTV is installed, not when the image was captured.

"Personal information" means information which relates to an identifiable individual such as name, age, date of birth, identification numbers, financial standing, credit records, and convictions if any. Thus, any information or opinion of an individual whose identity is disclosed or can reasonably be ascertained from the information or opinions is protected. However the protection does not include any information about an individual that is readily available to the public.

"Physical intrusion" is one aspect of privacy protected by the Bill. Physical intrusion means intrusion into an individual's physical space or solitude. This definition allows a claimant to invoke the Bill if his or her state of being alone or with a few selected others is interfered with.

\section{B Right to privacy}

4. (1) Every individual has a general right to privacy.

(2) The right to privacy is the right to the degree of privacy which is reasonable in all the circumstances having regard to the rights of others and of the public at large.

(3) The right to privacy in this Act complements the right to life and personal liberty under article 5 of the Federal Constitution and is to be read consistently with freedom of speech, assembly and association granted under article 10 of the Federal Constitution.

Section 4(1) establishes a general right to privacy and guarantees it to every individual. Section 4(2) assures the right to privacy that is reasonable in all the 
circumstances having regards to the rights of others and of the public at large. To complement such assurance, s 4(3) provides that the protection of privacy must be read consistently with the right to life and personal liberty under art 5 of the Federal Constitution. What is envisaged, then, is development of a privacy action which is consistent with the rights in art 5 and a permissible defensible limitation on freedom of expression in art 10. Reference to art 5 of the Constitution is in conformity with the obiter dicta in Sivarasa that the right to personal liberty includes the right to privacy. ${ }^{14}$

The Constitution is the supreme law. It is a basic constitutional principle that a law inconsistent with the Constitution is void. The object of s 4(3) is to signal awareness of that fact and maybe to avert any direct constitutional challenge. In one sense subsection (3) is redundant. In any eventual legislative initiative, government officials might choose to omit it for that reason. It is retained in the draft because it is deemed appropriate to state that the Bill is not intended to be inconsistent with constitutional principle - it can be read compatibly with arts 5 and 10. The focus of any interpretation should be on working out of the relationship of the privacy tort with any constitutional extension of art 5 to privacy rather than on supporting incompatibilities. The aim is to give some direction to the interpretive endeavours of the court to favour as positive and expansive interpretation as possible rather than one that unduly restricts the range of the tort.

Section 4 also acknowledges the consistency of the right to privacy with freedom of speech, assembly and association under art 10. It grants every citizen the right to freedom of speech and expression. The right, however, does not make the freedom an absolute right. It is a positive right that cannot be denied by government but subject to limitations which secure the broader

\footnotetext{
${ }^{14}$ See Sivarasa; See also Zuryati Mohamed Yusoff "Constitutional Protection of Privacy in Malaysia: A case study" [2011] 1 LNSA lxxix. For general discussion of art 5, see above Chapter Three, Part III.
} 
interests of the community. In PP v Ooi Kee Saik ${ }^{15}$ Raja Azlan Shah J quoted from AK Gopalan v State of Madras: ${ }^{16}$

\begin{abstract}
There cannot be any such thing as absolute or uncontrolled liberty wholly free from restraint; for that would lead to anarchy and disorder. The possession and enjoyment of all rights... are subject to such reasonable conditions as may be deemed to be... essential to the safety, health, peace and general order and morals of the community... What the Constitution attempts to do in declaring the rights of the people is to strike a balance between individual liberty and social control.
\end{abstract}

Section 4(3) also provides a caution in order to safeguard the entrenched right to life and personal liberty, and the right to speech, assembly and association. As the supreme law of the Federation, any rights guaranteed by the Constitution enjoy the highest respect and outweigh other rights not expressly provided by the Constitution. The establishment of the right to privacy in the Bill may interfere with the constitutionally protected rights, but limitations and restrictions are acceptable in the interest of the security or public order. In these circumstances, Parliament may pass law prohibiting the questioning of any matter, right, status, position, privilege, sovereignty or prerogative established or protected by the provisions of Part III, arts 152, 153 or 181 of the Federal Constitution. It is important to highlight that each and every such article except art 7 imposes the caveat "save in accordance with law" or something to similar effect. ${ }^{17}$

\footnotetext{
${ }^{15}$ [1971] 2 MLJ 108, at [17].

${ }^{16}[1950]$ AIR SC 27.

${ }^{17}$ Part II of the Federal Constitution provides for the Fundamental Liberties which includes the rights as set out in arts 5 -13. See arts 5(1), 6(2), 8(2)(5), $9(2)(3), 10(2)(3)(4), 11(4), 12(1)$ read together with arts 8 and 13(1).
} 
Further restrictions may be imposed for the maintenance of public order, ${ }^{18}$ morality, ${ }^{19}$ and protection of the privileges of the Parliament or of any legislative assembly. ${ }^{20}$ Parliament also can make laws against contempt of court, $^{21}$ defamation ${ }^{22}$ and incitement to any offence. ${ }^{23}$

Freedom of expression, therefore, is not absolute and may be qualified by ordinary statute. In Asia, there are different ways of deciding how to balance rights and restraints. In India, art 19 of the Constitution permits Parliament to impose "reasonable restriction" on free speech. Such phraseology gives the courts the ultimate power to accept or reject legislation on the ground of reasonableness. The framers of the Malaysian Constitution rejected this approach and decided in favour of Parliament rather than the court to determine the reasonableness, expediency or necessity of legislation. However, Parliament's legislative power is not unlimited. It can enact legislation only on permissible grounds and only in order to promote the objects enshrined in the constitutional provisions dealing with the freedom. ${ }^{24}$

The protection of privacy provided by the Bill is general because the concept itself has still not been addressed widely in Malaysia. As discussed in Chapter Three, although some cases on privacy were brought to the court, there has been no attempt to define it precisely; thus its scope remains debatable. Some commentators stress its importance for the promotion of dignity, some for the

\footnotetext{
${ }^{18}$ Relevant laws for the preservation of public order are the Sedition Act 1948, the Police Act 1967, the Printing Presses and Publications Act 1984 and the Broadcasting Act 1988.

${ }^{19}$ Legislation permitted under this head includes the Betting FM Ordinance 1953, the Films (Censorship) Act 1952, the Indecent Advertisements Act 1953, the Lotteries Act 1952, the Medicines (Advertisement and Sale) Act 1956, the Printing Presses and Publications Act 1984 and Perbadanan Kemajuan Filem Nasional Malaysia Act 1981.

${ }^{20}$ The Houses of Parliament (Privileges and Powers) Act 1952 and the standing orders of each House of Parliament are derivable from art 10(2)(a).

${ }^{21}$ The restrictive provisions of the Judicial Proceedings (Regulation of Reports) Act 1962 and the Courts of Judicature Act 1964 are justifiable under this exception.

${ }^{22}$ The Defamation Act 1957 is derived from this constitutionally permissible restriction on free speech.

${ }^{23}$ Offences like obscenity (ss 292 to 294 of the Penal Code) or causing disharmony, disunity on grounds of religion (s 298A).

${ }^{24}$ Shad Saleem Faruqi "Free Speech and the Constitution" [1992] 4 CLJ lxiv.
} 
development of the autonomous individual; and some for the preservation of health, well-being, or the development of relationships, and appropriate social interaction. ${ }^{25}$ This variety of interests indicates that privacy is worth protecting without limiting its category to a specific type of breach. This is the intention of the Bill.

The establishment of the statutory tort of privacy would place great weight on privacy rights at the expense of other rights and interests. The availability of the public interest defence provides a safeguard to other recognised interests and ensures that privacy interests are not privileged over other rights and interests.

Thus, the right to privacy as established by the Bill is not absolute. As stated in s 3 (2)(b) of the Bill, privacy competes with other rights and interests. In McKennit, Eady $\mathrm{J}$ noted that balancing of these rights does not occur in a vacuum and that public attitudes towards this may change along with societal expectations: ${ }^{26}$

\begin{abstract}
It is clear that [in the United Kingdom] there is a significant shift taking place as between, on the one hand, freedom of expression for the media and the corresponding interest of the public to receive information, and, on the other hand, the legitimate expectation of citizens to have their private life protected... Even where there is a genuine public interest, alongside a commercial interest in the media in publishing articles or photographs, sometimes such interest would have to yield to the individual citizen's right to the effective protection of private life.
\end{abstract}

\footnotetext{
${ }^{25}$ NA Moreham "Privacy Rights" in Mark Warby, Nicole Moreham \& Iain Christie (eds) Tugendhat \& Christie The Law of Privacy and the Media (Oxford University Press, 2011) at 59.

${ }^{26}$ McKennitt v Ash [2005] EWHC 3003 (QB) at [57].
} 
However, the court should recognise and give appropriate effect to the values involved in the broad concept of privacy and the right to freedom of expression. The introduction of the Bill will strengthen the position of the implicit right to privacy developed from art $5 .^{27}$

Explicit constitutional protection gives freedom of expression a higher legal standing than privacy interests. This is different from the situation in the United Kingdom where privacy and freedom of expression are both recognised in the HRA. ${ }^{28}$ Regardless of whether it is protected by a constitution or a statute, freedom of expression tends to be conceived, and protected, in a manner broadly consistent with the approach taken in art 19 of the ICCPR. In other words, freedom of expression is regarded as a right of fundamental importance although, in certain circumstances, ${ }^{29}$ it must be reconciled with other competing rights or interests.

The range of restrictions on the freedom is in line with art 10 of the ECHR. The right is wide enough to cover the freedom to hold opinions and to receive and impart information and ideas without interference by the public authority and regardless of frontiers. However, the exercise of these freedoms may be subject to certain formalities, conditions, restrictions or penalties as are prescribed by law and necessary in a democratic society.

The constitutional protection accorded to the right to free expression creates an expectation that the right can be exercised without undue restrictions. It also gives the impression that the right has an exclusionary force that should

\footnotetext{
${ }^{27}$ See above Chapter Three, Part III.

${ }^{28}$ Human Rights Act 1998 (UK) (ss 1, 12 and 13).

${ }^{29}$ For example art 19(3) of the ICCPR provides certain restrictions on the right to freedom of expression (a) For respect of the rights or reputations of others; (b) For the protection of national security or of public order (ordre public), or of public health or morals. Similarly, art 10(2) of Malaysian Constitution restricts freedom of speech as it deems necessary or expedient in the interest of the security of the Federation or any part thereof, friendly relations with other countries, public order or morality and restrictions designed to protect the privileges of Parliament or of any Legislative Assembly or to provide against contempt of court, defamation, or incitement to any offence.
} 
be protected. However, there are other interests, public or private, that require equal protection in order to preserve the socio-political framework of the Malaysian democratic society, and those other interests undoubtedly include the right to privacy.

\section{Breach of privacy}

5. (1) A breach of the right to privacy occurs if inter alia-

(a) there has been unwanted access to personal information; or

(b) there has been unwanted access to the physical body or space of an individual; or

(c) an individual's correspondence or private written, oral or electronic communication has been interfered with, misused or disclosed; or

(d) sensitive facts relating to an individual have been disclosed.

(2) For the purpose of establishing liability for a breach of the right to privacy, a claimant must show that in the circumstances of the breach there is a reasonable expectation of privacy.

(3) For the purpose of establishing a reasonable expectation of privacy, all relevant circumstances must be taken into account including-
(a) the nature of the activity;
(b) the place of occurrence of the incident;
(c) the nature and purpose of the intrusion;
(d) the attributes of the claimant;
(e) the effect on the claimant;
(f) the absence of consent. 
The Bill does not define privacy; instead it specifies situations in which a breach of privacy may occur. The list is not exhaustive and may be developed by the courts.

Section 5 deals with breach of the right to privacy. Section 5(1)(a) provides that a breach is said to have been taken place if there is "an unwanted access to personal information". "Unwanted access" suggests the state of inaccessibility to an individual's personal information. As discussed in Chapter Two, Gavison defined privacy as “a limitation of others' access to an individual", 30 or "freedom from unwanted access" 31 as Moreham put it. Thus, if A collects information about B's private wedding and discloses it to friends, B could maintain an action for breach of privacy against A under the Bill.

A breach of the right to privacy may occur where there has been unwanted access to the physical body or space of an individual as provided by 5(1)(b). Searching private space, intercepting a conversation, unwanted watching and spying are examples of unwanted access under this provision. ${ }^{32}$

Section 5(1)(c) provides for situations in which a breach occurs through interference, misuse or disclosure of an individual's privately written correspondence, or oral or electronic communication. This safeguards situations where personal mail is opened or read without good reason or email is hacked.

Section $5(1)(d)$ provides for a situation where sensitive facts relating to an individual have been disclosed. Factors surrounding the disclosure such as the nature, the manner and the extent of the disclosure are assessed in determining whether such disclosure constitutes a breach of the right to privacy. The

\footnotetext{
${ }^{30}$ Gavison, above ch 2, n 28, at 428.

${ }^{31}$ Moreham, above ch $2, \mathrm{n} 89$, at 636 .

${ }^{32}$ These examples are discussed in NA Moreham "The right to respect for private life in the European Convention on Human Rights: A re-examination" (2008) 1 EHRLR 44.
} 
revelation of a person's secrets, financial matters, religious and political beliefs, sexual fantasies or medical misadventures are categories of sensitive facts protected by the Bill.

The action for a breach of the right to privacy is not limited to activities taking place in the home or other private places. The test to determine the circumstances giving rise to the cause of action is whether the particular activity gives rise to a reasonable expectation of privacy, regardless of whether it occurs in public or private. The fact that an activity takes place in public does not mean that an expectation of privacy cannot arise. For example, in Hosking, a reasonable expectation of privacy did not arise because the photographs were taken in public and disclosed "nothing more than could have been observed by a member of the public in Newmarket on that particular day". On the other hand, the activity photographed in Campbell was in public, but it revealed information about Campbell's health, a category that has long been considered sensitive and private. These two cases clearly found that the place where the breach took place could not be the soledeterminant of whether a breach of privacy has occurred.

Section 5(2) provides that a test of reasonable expectation of privacy must be satisfied in order for a breach to arise. For the purpose of establishing liability for a breach of the right to privacy, a plaintiff must show that in the circumstances of the breach, there is a reasonable expectation of privacy. The question to be asked is whether the claimant had a reasonable expectation of privacy in respect of the information disclosed or the activities in question. Where the tort of disclosure of information involved, the information must be of a private nature. This is essentially the touchstone of private life identified by Lord Nicholls in Campbell. ${ }^{33}$ On the other hand, if no disclosure of information is involved, an intrusion into seclusion must be intentional and unauthorised, adopting the first three elements in Holland. Thus the test of

\footnotetext{
${ }^{33}$ Campbell at [21].
} 
reasonable expectation of privacy chosen by the Bill resembles the practice of English courts in deciding whether a breach has taken place.

As discussed in Chapter Five, in order to determine whether a reasonable expectation of privacy exists, the underlying consideration is whether the information concerned is private and not public. ${ }^{34}$ Thus, if obviously private information is disclosed, the person to whom it relates can bring an action of a breach of privacy, and the court will decide accordingly without the need to consider other relevant factors. However, if it is not a straightforward disclosure of obviously private information, the court is obliged to consider other relevant circumstances as set out in s 5(3).

The circumstances include the attributes of the claimant, the nature of the activity, the place of occurrence of the incident, the nature and purpose of the intrusion, the absence of consent and the effect on the claimant. These considerations are adopted from Murray $v$ Express Newspapers plc. ${ }^{35}$ The test suggested in Murray requires consideration of all circumstances surrounding the facts before a breach may be established. The guidelines make it easier for the court to ascertain whether a claimant has a reasonable expectation of privacy in the circumstances of the case.

In relation to the place of occurrence, Moreham suggested that a reasonable expectation of privacy may arise in public where a person involuntarily experiences an intimate or traumatic event in public, is in a place where he or she expects to be unnoticed, or where the defendant has used technological devices to penetrate his or her clothes or other self-protection barriers. ${ }^{36}$ Therefore, a breach of privacy occurs if a long lens camera is focused on a plaintiff sitting beside her loved ones on the road as a result of a fatal accident

\footnotetext{
${ }^{34}$ At [92] and [96].

${ }^{35}$ [2009] 1 Ch 481 (CA) at [36].

${ }^{36}$ NA Moreham "Privacy in Public Places" (2006) 65 Cambridge LJ 606, at 635.
} 
and the photos are distributed publicly, regardless of the fact that the incident occurred in a public place.

The second-tier test of "highly offensive to a reasonable person of ordinary sensibilities" formulated in Hosking was disregarded in the Bill because it required a high standard approach and was stricter. It was largely based on a possible collision between tort of privacy and freedom of expression. However, in the Malaysian context, this would be unlikely due to the status of freedom of expression as an entrenched right. The Court of Appeal determined that these two rights must be kept within tight confinement. ${ }^{37}$ Thus, when prescribing the tort, Gault $\mathrm{P}$ and Blanchard $\mathrm{J}$ agreed not only that there must be a reasonable expectation of privacy, but also that the publication of the facts must be highly offensive to a reasonable person. The law in Hosking established that both elements must be proved although Tipping $\mathbf{J}$ was inclined to think that the highly offensive test was a contributing factor when deciding whether a reasonable expectation of privacy existed in a particular case.

Moreham expresses the view that since privacy is a dignitary tort, it is actionable without proof of damage, thus any interference is prima facie actionable. $^{38}$ The highly offensive test suggests that injury in the form of offence is necessary. It is quite unsatisfactory to regard the disclosure as offensive when facts about an individual's activities are published. For example, publication of a photograph of a person having a breakfast with someone contains no offensive elements but may be humiliating and distressing if that person wishes the photo to remain private.

As discussed in Chapter Five, the English courts do not regard the highly offensive test as a separate requirement. The Bill accepts the English courts'

\footnotetext{
${ }^{37}$ Hosking, at [130].

${ }^{38}$ Moreham “Why is Privacy Important?” above ch 2, n 9, at 231.
} 
approach which rejected the test of "highly offensive" element in determining the private nature of the information, because "offensiveness" is not an appropriate way of characterising the harm caused. In Malaysia, matters of offence are dealt with in specific offences relating to modesty. In this regard, the Bill treated offensiveness in the same way as the UK do. ${ }^{39}$ The thesis submits that, it is quite unsatisfactory to regard the disclosure as offensive, rather humiliating and distressing when facts about an individual's activities are published.

$A \cup B$ Plc, Douglas and Campbell, show that the reasonable expectation test is an appropriate vehicle for the protection of privacy. The test not only reflects the subjective nature of the privacy interest, but also encompasses physical and informational privacy interference. ${ }^{40}$

Following the English position of establishing whether a breach has taken place, the Bill adopts the test of reasonable expectation of privacy as the only determining factor for the breach. In Malaysia, the standard of the "reasonable person" is employed for determining negligence in the law of torts. This thesis suggests the same test be applicable in cases of breach of privacy. Thus, in order to ascertain whether a breach exists, the primary consideration is how a reasonable person would feel if placed in the position of the claimant and faced with the same publicity or intrusion. If the answer is in the affirmative, the court would clearly find that a breach has taken place.

\section{Claims}

6. (1) An individual whose right to privacy has been breached may bring an action for relief in accordance with the procedures for civil claims.

\footnotetext{
${ }^{39}$ See discussions above in Chapter Five, at 166-167 and Chapter 6, at 201-202.

${ }^{40}$ See Moreham, above ch 2, n 89, at 656.
} 
(2) A breach of the right to privacy is actionable -

(a) without proof of damage; and

(b) if the breach was either intentional or negligent.

(3) Any action brought under this Act is in addition to but not in derogation from the common law, subject only to the rule that the same relief may not be granted more than once in respect of the same breach.

(4) The bringing of a claim under this Act has no effect on any criminal prosecution in respect of the same facts.

Section 6 provides that an action for a breach of privacy may be brought by an individual in accordance with the procedures for civil claims. A breach is actionable even though the claimant suffers no damage and has no knowledge of the breach as in the case of trespass to land, to person or interference to goods. $^{41}$

A key feature of the Bill is that the breach of privacy is actionable without proof of damage. This is because an action for a breach of the right to privacy is based on humiliation, distress and loss of dignity. That is to say, a plaintiff need not have to bring additional facts to constitute a cause of action and is not barred from bringing an action solely on the basis of inability to demonstrate an injury or loss However, the absence of such injury or loss could be a factor in deciding the type of remedy or quantum of damages. The breach of privacy will also be actionable where the breach was either intentional or negligent. Thus, a claimant's state of knowledge is not a prerequisite for a breach of privacy to be actionable.

With regard to the above issue, Lord Hoffman's comment is a good explanation for s $6:^{42}$

\footnotetext{
${ }^{41}$ See Norchaya Law of Torts in Malaysia, above ch $3 \mathrm{n} 68$, at 9.

${ }^{42}$ Wainwright v Home Office [2004] 2 AC 406, at [51].
} 
Although art 8 guarantees a right of privacy, I do not think that it treats that right as having been invaded and requiring remedy in damages, irrespective of whether the defendant acted intentionally, negligently or accidentally. It is one thing to wander carelessly into the wrong hotel bedroom and another to hide in the wardrobe to take photographs.

\section{E Defences}

7. It is a defence to an action under this Act for the defendant to prove that the act in respect of which the action was brought -

(a) was done for the purpose of lawfully defending or protecting a person or property, or

(b) was authorised or required by law or by a court, or

(c) was done by a public servant in accordance with s 8 -

(i) acting in the course of his or her duties, or

(ii) in circumstances where he or she had reasonable grounds for believing that he or she was acting in the course of his or her duties, or

(iii) was an act of newsgathering, where disclosure of material obtained as a result of such act was -

(i) done in good faith; or

(ii) for the purpose of discussing a subject of public interest;

or

(iii) for the public benefit; and

(iv) fair and reasonable in all of the circumstances; or

(v) was done with the consent of the claimant.

Section 7 provides specific defences available to the defendant in privacy action. A defence to a claim of privacy violation may exist if it is deemed that the information is of legitimate public interest or otherwise newsworthy. Public interest is upheld as a defence, rather than an element for the tort. The 
Bill retains "public interest" compared with New Zealand's defence of "legitimate public concern" because "public interest" is already a familiar term in Malaysia. It is used and recognised in the context of defamation, nuisance, contract and other branches of law that require public interest considerations to be taken into account. If a breach is established by satisfying the test of reasonable expectation of privacy, the next question to consider is whether it is justified. If other matters of public interest outweigh the privacy of the individual, the claim will not be sustained. In other words, the scope of privacy protection should not exceed the limits of freedom of expression and other matters of public interest.

In cases of publication of information about activities of public figures that may reflect on the position they hold that the public has the right to know, such information would not amount to a breach under the Bill. On the other hand, a newsworthy defence requires that it is timely, so while the subject and information may once have been newsworthy, years later that may no longer be the case; and publication of the information may not be protected by this defence.

The above provision also allows a defendant in an action for a breach of privacy to prove that the action occurred for the purpose of lawfully defending or protecting a person or property. ${ }^{43}$ A strong defence exists if the act was authorised or required by law or by a court. Public servants have a defence if the act took place in accordance with s 8 and they were acting in the course of their duties, or in circumstances where they had reasonable grounds for believing that they were acting in the course of their duties. A reporter or journalist has a defence if disclosure of information occurred in good faith or

\footnotetext{
${ }^{43}$ This provides an exception or immunity to lawyers prosecuting or defending proceeding in court. The process of litigation itself requires a lot of information to be discussed between the lawyer and clients. If any breach occurs in the process of obtaining the information, it is protected by the Bill.
} 
for the purpose of discussing a subject of public interest and benefit, and was fair and reasonable in all circumstances.

\section{F Exemption from liability}

8. No claim can be made for interference with the right to privacy where a public authority acts -

(a) in accordance with the law, and

(b) as is necessary in a democratic society-

(i) in the interest of national security;

(ii) public safety or the economic well-being of Malaysia;

(iii) for the prevention of disorder or crime;

(iv) for the protection of health and morals; or

(v) for the protection of the rights and freedoms of others.

As discussed in Chapter Four, the PDPA does not apply to the public sector. With a view to remedying that limitation, the Bill applies to everybody. However, s 8 gives a public authority ${ }^{44}$ exemption from liability if the interference occurs in accordance with the law and is necessary for the interest of national security, public safety or economic well-being, prevention of disorder or crime, for the protection of health and morals or for the protection of the rights and freedoms of others.

It is important to acknowledge a public authority's special position and to provide for a necessary exemption in carrying out public duties. This exemption, as opposed to defences under $\mathrm{s} 7$, is in line with the exemption provided by the ECHR and only applicable to public authority. Therefore, in

\footnotetext{
${ }^{44}$ According to art 160 of the Federal Constitution, "public authority" means the "Yang diPertuan Agong (the King), the Ruler or Yang di-Pertuan Negeri of a State, the Federal Government, the Government of a State, a local authority, a statutory authority exercising powers vested in it by federal or State law, any court or tribunal other than the Supreme Court and High Courts, or any officer or authority appointed by or acting on behalf of any of those person, courts, tribunals or authorities".
} 
determining a breach of privacy by a public authority, the court will look at $\mathrm{s}$ 8 justifications and the claimant's privacy rights. On the other hand, in cases of a breach between individuals, the defendant may be absolved from the liability if any of the defences provided under s 7 justifies the breach.

\section{G Procedural Orders}

9. Where a claim is brought under this Act, the High Court shall make such orders as it thinks fit for anonymity and the protection of the privacy of any individual.

Section 9 provides that the High Court may make such orders as it thinks fit for anonymity and the protection of the privacy of any individual. This is to preserve individual's privacy and confidentiality in civil proceedings, and thus balancing the privacy right with the principle of open justice.

The principle of open justice is a long-established and fundamental aspect of the justice system in any country committed to the rule of law. ${ }^{45}$ In the administration of justice, the paramount requirement is that justice should be done openly. A fundamental principle of the common law since its origins is that justice is conducted, and judgments are given in public. ${ }^{46}$ This principle is, as Lord Shaw described it in Scott v Scott, ${ }^{47}$ "a sound and very sacred part of the constitution of the country and the administration of justice". ${ }^{48}$ Open justice is of constitutional importance because it is "on the whole, the best security for the pure, impartial, and efficient administration of justice, the best means for winning for public confidence and respect". 49

\footnotetext{
${ }^{45}$ Lord Neuberger of Abbotsbury "Privacy and Freedom of Expression: A Delicate Balance" (2011) 1 LNS(A) lxxii.

${ }^{46}$ Daubney v Cooper (1829) 109 ER 438; 10 B \& C 237 at 240; Scott v Scott [1913] AC 417 at 438 (per Lord Haldane LC); Richmond Newspapers Inc v Virginia 448 (US) 555. ${ }^{47}[1913]$ AC 417.

${ }^{48}$ At 473; see also Attorney General v Leveller Magazine [1979] AC 440 at 449 - 450.

${ }^{49}$ At 463; and Lord Shaw at 476; Axen v Germany [1984] 6 EHRR 195 at [25]- [27].
} 
It is also important to emphasise that in this context the proper administration of justice has two elements. ${ }^{50}$ First, it refers to the court's ability to administer justice between the parties in a particular case. In the proceeding for the tort of misuse of private information or breach of confidence, justice can be done by properly protecting private and confidential information which may be fatally undermined if the proceedings themselves were conducted entirely in public and the judgment were also entirely public. In such a situation, strict adherence to the general principle may be inconsistent with the court's duty to do justice. $^{51}$

The second element stemmed from the need to apportion justice between parties. Richardson $\mathbf{J}$ in the New Zealand Court of Appeal in Moevao $v$ Department of Labour ${ }^{52}$ said:

And the due administration of justice is a continuous process, not confined to the determination of the particular case. It follows that in exercising its inherent jurisdiction the Court is protecting its ability to function as a Court of law in the future as in the case before it. This leads on to the second aspect of the public interest which is the maintenance of public confidence in the administration of justice. It is contrary to the public interest to allow that confidence to be eroded by a concern that the Court's processes may lend themselves to oppression and injustice.

Article 6 of the ECHR provides that open justice in civil proceedings can properly yield to privacy:

\footnotetext{
${ }^{50}$ These two elements are discussed in Report of the Committee on Super-Injunctions: SuperInjunctions, Anonymised Injunctions and Open Justice (Judiciary of England and Wales, 2011). [1.20]-[1.21] <http://www.judiciary.gov.uk/Resources/JCO/Documents/Reports/super-injunction-report20052011.pdf> [Super-Injunctions].

${ }^{51}$ At [1.20]-[1.21].

${ }^{52}$ [1980] 1 NZLR 464 at 481; Refer also Super Injunctions, above n 47, at [1.21].
} 
Judgment shall be pronounced publicly but the press and public may be excluded from all or part of the trial in the interest of morals, public order or national security in a democratic society, where the interests of juveniles or the protection of the private life of the parties so require, or to the extent strictly necessary in the opinion of the court in special circumstances where publicity would prejudice the interests of justice.

This thesis suggests that proceeding of a privacy action should be done in an open court but, whenever necessary, the court may make an order for claimant's anonymity that the identification and particulars of that person will not be disclosed. In the UK and New Zealand, restrictions on publication are often enough to safeguard the claimant's interest. ${ }^{53}$

\section{H Appeals}

10. Any party who is not satisfied with or is aggrieved by the decision of the High Court may appeal to the Court of Appeal.

Section 10 allows a party not satisfied with the decision of the High Court to appeal to the Court of Appeal on the question of law only. Such a procedure is provided by s 67 of the Courts of Judicature Act 1964 which gives the power to the Court of appeal to hear and determine appeals from any judgment or order of any High Court in any civil cause or matter, whether made in the exercise of its original or of its appellate jurisdiction. Upon hearing an appeal of a decision by the High Court, the Court of Appeal may make such orders it considers appropriate. ${ }^{54}$

\footnotetext{
${ }^{53}$ See for example, ss 39 and 49 of the Children and Young Persons act 1933 (UK); s 8 of the Magistrate's Court Act 1980 (UK); ss 11B-11D of the Family Courts Act 1980 (NZ) and s 125 of the Domestic Violence Act 1995 (NZ).

${ }^{54}$ Section 69(1)-(5) of the Courts of Judicature Act 1964 (Malaysia) provides that "appeals to the Court of Appeal shall be by way of re-hearing." On re-hearing, the Court of Appeal may
} 
11. (1) The remedies available in respect of a breach of the right to privacy include-

(a) Temporary and perpetual injunctions in accordance with section 51 of the Specific Relief Act 1950 and mandatory injunctions specified under section 53 of the Specific Relief Act 1950;

(b) Damages;

(c) An account of profits;

(d) Property confiscation or destruction orders;

(e) A declaration of breach of privacy;

(f) Apology.

(2) The court may award any or all of these remedies as it sees fit in relation to the specific facts of the case.

(3) The court shall have power to order costs to be borne by either party.

Section 11 lists remedies available in respect of a breach of privacy and includes injunctions, damages, an account of profits, property confiscation or destruction orders, declaration of breach of privacy, and apology. The award may be one or all of the remedies available under this section. The court also may order costs to be borne by either party.

Injunction is one of the most popular remedies in privacy actions in New Zealand. It has been awarded since invasion of privacy was first mooted as a possible tort. ${ }^{55}$ The same position applies in England. ${ }^{56}$ Injunctions are

draw inferences of fact, and give any judgment, and make any order which ought to have been given or made, and make such further or other orders as the case requires.

${ }^{55}$ Among other cases where an injunction was awarded were Tucker v News Media Ownership Ltd [1986] 2 NZLR 716, Morgan v Television New Zealand (1 March 1990) HC CH CP 6790, P v D [2000] 2 NZLR 591 (HC).

${ }^{56}$ For example in McKennitt and others $v$ Ash [2008] QB 73, the court granted an injunction preventing further publication of a significant part of the work complained of on the ground 
awarded because plaintiffs want to stop infringements of their privacy before they occur rather than afterwards.

In this Act, temporary and perpetual injunctions are available in the case of a breach of privacy in accordance with s 51 of the Specific Relief Act $1950^{57}$ and mandatory injunctions are provided by s 53 of the Specific Relief Act 1950.58

Damages may also serve as an appropriate remedy for cases involving invasion of privacy. In Hosking, the court made it clear that damages were the main remedy for breach of privacy. ${ }^{59}$ In Lee Ewe Poh, the court stated that in order to qualify for aggravated damages, the acts must be calculated to injure the feelings of the plaintiff. ${ }^{60}$ The court accepted that aggravated damages as a form of a higher compensation showed disapproval of the defendant's acts because they were carried out in such a manner that the plaintiff suffered more than would normally be expected in such a case. ${ }^{61}$ It is suggested that the same approach should be taken in the context of the privacy tort.

The award of exemplary damages, also known as punitive damages may be debatable in the context of a privacy action. This is because, in Malaysia, exemplary damages aim to reform or deter the defendant and others from

that it constituted private information under art 8 of the ECHR. See also A v B plc, above ch 5 , at 170 .

${ }^{57}$ Section 51 provides that temporary injunctions continue until a specified time, or until the further order of the court. They may be granted at any stage of a suit, and are regulated by the law relating to civil procedure. A perpetual injunction can only be granted by the decree made at the hearing and upon the merits of the suit; the defendant is thereby perpetually enjoined from the assertion of a right, or from the commission of an act, which would be contrary to the rights of the plaintiff.

${ }^{58}$ Section 53 provides "When, to prevent the breach of an obligation, it is necessary to compel the performance of certain acts which the court is capable of enforcing, the court may in its discretion grant an injunction to prevent the breach complained of, and also to compel performance of the requisite acts".

${ }^{59}$ Hosking at [149].

${ }^{60}$ Lee Ewe Poh, at [18].

${ }^{61}$ The court in Lee Ewe Poh referred to Catherine Elliot and Frances Quinn Tort Law $\left(7^{\text {th }}\right.$ ed, Pearson Longman, England, 2009). 
engaging in similar conduct. They are, however, often awarded where compensatory damages are deemed an inadequate remedy. Malaysian courts have followed and applied the law relating to exemplary damages in tort expounded by Lord Devlin in Rookes $v$ Barnard. ${ }^{62}$ The principles were applied in Solid Gold Publishers Sdn Bhd v Chan Wee Ho \& Ors ${ }^{63}$ where the judge held that the awards of exemplary damages should be moderate and it may properly be awarded to deter the tortfeasor. In awarding such award, evidence of the tortfeasor's means is material not only to show that he can afford to satisfy a substantial judgment but to show what sum will be a sufficient deterrent against the repetition of the conduct that attract the award. ${ }^{64}$ Similarly, in Alfred Templeton \& Ors v Low Yat Holdings Sdn Bhd \& Anor ${ }^{65}$ the judge awarded the plaintiff exemplary damages because the defendants' wrongdoing was committed with a profit making motive, highhandedly and outrageously, with a contumelious disregard for plaintiffs' rights and the plaintiffs were victims of the defendants' punishable behaviour. $^{66}$

Thus, in defamation action, punitive or exemplary damages are likely to be awarded where the defendant has deliberately or recklessly, published the defamatory statements with the knowledge that the economic benefit from the publication outweigh any sum for which he might be liable in damages. The rationale behind such an award is to show that the defendant cannot break the law with impunity and it is only made when compensatory damages are insufficient to serve this aim of punishment. ${ }^{67}$ Having said so, it is important to note that, as the nature of privacy breach and its effect is akin to that what

\footnotetext{
${ }^{62}$ [1964] AC 1129. Lord Devlin laid down three rules for an award of exemplary damages; (i) when power to do so is authorised by statute; (ii) when the conduct by government servants is oppressive, arbitrary or unconstitutional and (iii) when the conduct is calculated to result in profit.

${ }^{63}[2002] 3$ MLJ 310.

${ }^{64}$ At 313 .

${ }^{65}$ [1989] 2 MLJ 202 (Alfred). See also Cheng Hang Guan \& Ors v Perumahan Farlim (Penang) Sdn Bhd \& Ors [1993] 3 MLJ 352.

${ }^{66}$ See Alfred, at 232-233.

${ }^{67}$ Chong Siew Chiang v Chua Ching Geh \& Anor [1995] 1 MLJ 551.
} 
is suffered by a person defamed, a similar approach should be taken in privacy action. As the Bill in s 6 provides that the breach of privacy is actionable regardless of the claimant's state of knowledge, the court may grant an award of exemplary damages which it thinks is most appropriate in the circumstances.

However, in Mosley $v$ News Group Newspapers Ltd ${ }^{68}$, the court held that exemplary damages were not available in a claim for infringement of privacy, since there was no existing authority to justify such an extension and because it would fail the tests of necessity and proportionality. Similarly, the court in Lee Ewe Poh acknowledged that the purpose of exemplary damages was to offer a serious punishment to the defendant and to deter others from behaving the same way. The court found, however, that the defendant's conduct was not sufficiently outrageous as to warrant exemplary damages that might punish and deter him. ${ }^{69}$

In assessing damages, the court may take into account factors including the extent of publication, the conduct of the defendant after publication, any contributory negligence by the plaintiff, the defendant's motive for publishing or intrusion, the age of the plaintiff and the extent of distress and hurt to the plaintiff.

If the defendant has made money from the plaintiff's personal information, the plaintiff may require all profits deriving from defendant's unlawful conduct to be released. The plaintiff also may apply for property confiscation or destruction orders; to require the defendant to surrender damaging documents to the plaintiff.

\footnotetext{
${ }^{68}$ [2008] EWHC 1777 (QB) Eady J at [197].

${ }^{69}$ Lee Ewe Poh, at [19].
} 
A claimant also may apply for a declaration of breach of privacy or open apology by the defendant. A declaration may be useful in situation where, as part of the vindication of his or her rights, a person wants the breach to be acknowledged. However, these two remedies are not as popular as damages and injunction, but they are alternative remedies that may be sought in privacy cases.

\section{J Limitation of action}

12. A privacy action under this Act is an action founded in tort for the purpose of section 6 of the Limitation Act 1953.

Section 12 provides that an action for a breach of privacy must be brought within six years from the date on which the cause of action occurred. This is in line with other civil claims provided by s 6 of the Limitation Act $1963 .^{70}$ If the victim does not take action against the infringement within the stipulated time, he or she loses the right because they have consented to the breach. To bring a privacy action under this Bill, the date of the cause of action shall be the date upon which the breach of privacy was first discovered by the plaintiff, or reasonably discoverable by the plaintiff in a particular case.

\section{K Personal data protection principles}

13. This Act operates in addition to and not in derogation from the protection of personal data under the Personal Data Protection Act 2010.

Section 13 provides for the application of this Bill in respect of matters related to personal data which are uncovered by the Personal Data Protection Act 2010. As discussed in Chapter Four, the PDPA was introduced to regulate and

\footnotetext{
${ }^{70}$ Section $6(1)(a)$ provides that actions founded on a contract or on tort shall not be brought after the expiration of six years from the date on which the cause of action accrued.
} 
protect the misuse of personal data through commercial transactions. Thus, it only safeguards confidentiality in the handling of an individual's personal data and prevents misuse of the data in relation to commercial transactions. Given its breadth, wider range of remedies is provided in cases where personal data protection principles are breached, but no remedies are available in the PDPA.

As discussed in Chapter Four, one of the shortcomings of the PDPA 2010 is the absence of remedy for the individuals whose data has been misused. No provision exists in the PDPA for compensation, injunction or appropriate remedy for the breach. ${ }^{71}$ Though correction of inaccurate information is granted under the PDPA, ${ }^{72}$ its main focus is on sanctions for breach. ${ }^{73}$ This may provide some deterrence, but does not compensate the victim. Thus, the provision for remedies provided by the Privacy Bill would make up for the insufficiency of protection provided under the PDPA. In other words, the Bill has no intention to contradict the personal data legislation rather it adds new dimension to it. It does not amend the PDPA nor derogate from it.

\section{Other laws}

14. Nothing in this Act operates in derogation from the provisions of the Official Secrets Act 1972, or of the Public Order (Preservation) Act 1958.

Section 14 relates to the relationship between this Act and other legislation. Nothing provided under the Act shall derogate from the provisions of the

\footnotetext{
${ }^{71}$ See Zuryati Mohamed Yusoff "The Malaysian Personal Data Protection Act 2010: A Legislation Note" [2011] 9 NZJPIL 119.

${ }^{72}$ Section 34 of the PDPA on the right to correct personal data.

${ }^{73}$ Section $5(2)$ of the PDPA.
} 
Official Secrets Act $1972\left(\right.$ OSA) ${ }^{74}$ or the Public Order (Preservation) Act $1958 .^{75}$

For example, the establishment of a general right to privacy under the Bill does not in every situation prevent a search and seizure to be executed under s 6 of the OSA. Similarly, the provisions of the Bill have no effect on penalties for spying ${ }^{76}$ prejudicial to the safety or interest of Malaysia. Neither do the provisions of the Bill prevent the Chief Police Officer or the Officer in Charge of a Police District to exercise their powers for the maintenance of public order. $^{77}$

\section{Summary}

The proposed law for the protection of privacy recognises a general right to privacy in Malaysia. The law reflects and is informed by relevant developments of the right to privacy in the UK and New Zealand. As acknowledged by courts in both jurisdictions, Parliament is the appropriate authority to introduce and develop privacy law and its remedies. The Bill provides a framework for the kind of privacy protection that would work for Malaysia. The recommendations and suggestions from Law Reform Commission Report of other jurisdictions particularly Australia which strongly support the enactment of a statutory cause of action for a serious invasion of privacy provide useful insights for the development of this Bill.

\footnotetext{
${ }^{74}$ The Official Secrets Act 1972 is an Act to revise and consolidate the law relating to the protection of official secrets.

${ }^{75}$ The Public Order (Preservation) Act 1958 is an Act relating to the maintenance and restoration of public order.

${ }^{76}$ Section 3 of the Official Secrets Act 1972.

${ }^{77}$ Part III of the Public Order (Preservation) Act 1958.
} 


\section{CHAPTER EIGHT CONCLUSION}

Infringements of personal privacy are a growing problem in Malaysia. A law should respond to these problems by providing appropriate protection of the right to privacy and its interests as defined in this thesis. Chapters Three and Four showed that the existing legal framework does not adequately protect these interests, thus, the need to address the existing situations. Malaysia needs a law on privacy that covers intrusion as well as informational privacy. References and developments from other jurisdictions can contribute to the formulation of the proposed law.

As discussed in Chapters Five and Six, the development of privacy law in the United Kingdom and New Zealand informs the development of privacy law for Malaysia. However, the English courts' approach of extending the doctrine of confidentiality to cases involving wrongful publication of private information may not be appropriate in Malaysia. Chapter Three made it clear that courts in Malaysia have taken a more conservative approach to breach of confidence. In all breach of confidence cases, Malaysian courts have followed the three elements in Coco. These elements have been applied strictly and no avenue so far exists to reformulate them so that the doctrine of confidentiality may provide protection for privacy.

On the other hand, the NZ approach of developing common law torts may be followed in Malaysia; indeed steps in this direction have already been taken, in, for example, the recent case of Maslinda Ishak. There the court decided that an invasion of privacy is actionable although it did not discuss the details of the cause of action. Further development is likely to be slow and piecemeal, dependent, as it is, on incremental case by case development. 
Given the remote probability of Malaysia's adopting the approach taken in the UK or NZ, this thesis submits that specific legislation for a Malaysian tort of privacy is desirable. This is, firstly, because the courts in Malaysia still rely on the law in Ultra Dimension which followed Kaye, and do not take into account changes to the English common law brought about by the HRA 1998, art 8 of the Convention, Douglas methodology and Campbell. This means that the long-abandoned principles in Kaye are still referred to by Malaysian courts. Secondly, recognising an explicit right to privacy in the Constitution will not be easy. This is because of the nature of the Constitution, and the amendment process that requires adherence to complicated and onerous procedures. Although Indian jurisprudence has, to a certain extent, influenced Malaysian decisions on human rights issues (especially the right to life and personal liberty), political, economic, religious and societal differences make it difficult to follow fully the Indian approach to constitutional privacy protection. Thirdly, to have a common law tort similar to that developed in New Zealand in Hosking and Holland would largely depend on the court's exercise of its powers when confronting a relevant case at some unknown time in the future.

It is not possible for Malaysia to adopt English and New Zealand approaches in their entirety but each development has significantly contributed to many aspects of the formulation of a statutory tort of privacy. This thesis concludes, therefore, that the best way for Malaysia to protect individual privacy is to have a general Act on privacy which is informed by relevant developments in the UK and New Zealand. Such an Act would provide guidance to courts on how the tort would determine the balance between privacy and freedom of expression and on appropriate remedies. It is necessary to place all aspects of privacy protection in a specific law which provides a firm foundation for subsequent judicial developments. 
This thesis focuses on two key aspects of the privacy interest: the protection of individual privacy in respect of information, and the physical body. The proposed law protects these two vital aspects of the privacy interest and provides a basis for the future extension of privacy protection in Malaysia. 


\begin{abstract}
APPENDIX
This is the proposed law of privacy for Malaysia discussed in Chapter Seven. The wordings in this Bill are sourced from other legislative models and reform proposals particularly the Ireland Privacy Bill 2006, the Australian Law Reform Commission, the New South Wales Law Reform Commission and the Victorian Law Reform Commission. However, necessary amendments to the wordings are made in conformity with Malaysian legislation.
\end{abstract}

PRIVACY BILL 2014

ARRANGEMENT OF SECTIONS

Section

1. Short title

2. Interpretation

3. Purpose

PART II

CAUSE OF ACTION

4. Right to privacy

5. Breach of privacy

6. Claims 


\title{
PART III
}

\section{DEFENCES}

7. Defences

8. Exemption from liability

\author{
PART IV \\ PROCEEDINGS
}

9. Procedural Orders

10. Appeals

PART V

REMEDIES

11. Remedies

\section{PART VI \\ MISCELLANEOUS}

12. Limitation of action

13. Personal Data Protection Principles

14. Other laws 


\section{LAWS OF MALAYSIA \\ PRIVACY BILL 2014}

An Act for the protection of the privacy of every individual and matters connected thereto.

ENACTED by the Parliament of Malaysia as follows:

PART I

PRELIMINARY

\section{Short title}

1. This is the Privacy Act 2014.

\section{Interpretation}

2. In this Act-

"disclose" means make information and other material concerning an individual known to the public or to a section of the public;

"individual" means a living natural person;

"interference" means the act of interfering or actions taken leading to the process of interfering;

"personal information" means information which relate to an identifiable individual;

"physical intrusion" means intrusion into the physical space or solitude of an individual; 


\section{Purpose}

3. (1) The purpose of this Act is to provide for the protection and respect of the dignity of individuals in their private and public lives both in terms of protection of personal information and freedom from physical intrusion.

(2) To that end, this Act -

(a) establishes a general right to privacy and provides for its protection;

(b) recognises that the right to privacy is not absolute and provides a framework within which to balance that right with other human rights, and with other public interests; and

(c) provides for redress when there has been a breach of the right to privacy.

\section{PART II \\ CAUSE OF ACTION}

\section{Right to privacy}

4. (1) Every individual has a general right to privacy.

(2) The right to privacy is the right to the degree of privacy which is reasonable in all the circumstances having regard to the rights of others and of the public at large.

(3) The right to privacy in this Act complements the right to life and personal liberty under article 5 of the Federal Constitution and is to be read consistently with freedom of speech, assembly and association granted under article 10 of the Federal Constitution.

\section{Breach of privacy}

5. (1) A breach of the right to privacy occurs if inter alia-

(a) there has been unwanted access to personal information; or

(b) there has been unwanted access to the physical body or space of an individual; or 
(c) an individual's correspondence or private written, oral or electronic communication has been interfered with, misused or disclosed; or

(d) sensitive facts relating to an individual have been disclosed.

(2) For the purpose of establishing liability for a breach of the right to privacy, a claimant must show that in the circumstances of the breach there is a reasonable expectation of privacy.

(3) For the purpose of establishing a reasonable expectation of privacy, all relevant circumstances must be taken into account including-

(a) the nature of the activity;

(b) the place of occurrence of the incident;

(c) the nature and purpose of the intrusion;

(d) the attributes of the claimant;

(e) the effect on the claimant;

(f) the absence of consent.

\section{Claims}

6. (1) An individual whose right to privacy has been breached may bring an action for relief in accordance with the procedures for civil claims.

(2) A breach of the right to privacy is actionable -

(a) without proof of damage;

(b) if the breach was either intentional or negligent.

(3) Any action brought under this Act is in addition to but not in derogation from the common law, subject only to the rule that the same relief may not be granted more than once in respect of the same breach.

(4) The bringing of a claim under this Act has no effect on any criminal prosecution in respect of the same facts. 


\section{PART III \\ DEFENCES}

\section{Defences}

7. It is a defence to an action under this Act for the defendant to prove that the act in respect of which the action was brought -

(a) was done for the purpose of lawfully defending or protecting a person or property; or

(b) was authorised or required by law or by a court; or

(c) was done by a public servant in accordance with s 8 -

(i) acting in the course of his or her duties, or

(ii) in circumstances where he or she had reasonable grounds for believing that he or she was acting in the course of his or her duties, or

(d) was an act of newsgathering, where disclosure of material obtained as a result of such act was -

(i) done in good faith; or

(ii) for the purpose of discussing a subject of public interest; or

(iii) for the public interest, and

(iv) fair and reasonable in all of the circumstances; or

(e) was done with the consent of the claimant.

\section{Exemption from liability}

8. No claim can be made for interference with the right to privacy where a public authority acts -

(a) in accordance with the law, and

(b) as is necessary in a democratic society-

(i) in the interest of national security;

(ii) for public safety or the economic well-being of Malaysia;

(iii) for the prevention of disorder or crime; 
(iv) for the protection of health and morals; or

(v) for the protection of the rights and freedoms of others.

\section{PART IV}

\section{PROCEEDINGS}

\section{Procedural Orders}

9. Where a claim is brought under this Act, the High Court shall make such orders as it thinks fit for anonymity and the protection of the privacy of any individual.

\section{Appeals}

10. Any party who is not satisfied with or is aggrieved by the decision of the High Court may appeal to the Court of Appeal.

\section{PART V}

REMEDIES

\section{Remedies}

11. (1) The remedies available in respect of a breach of the right to privacy include-

(a) Temporary and perpetual injunctions in accordance with section 51 of the Specific Relief Act 1950 and mandatory injunctions specified under section 53 of the Specific Relief Act 1950;

(b) Damages;

(c) An account of profits;

(d) Property confiscation or destruction orders;

(e) A declaration of breach of privacy;

(f) Apology. 
(2) The court may award any or all of these remedies as it sees fit in relation to the specific facts of the case.

(3) The court shall have power to order costs to be borne by either party.

\section{PART VI \\ MISCELLANEOUS}

\section{Limitation of action}

12. A privacy action under this Act is an action founded in tort for the purpose of section 6 of the Limitation Act 1953.

\section{Personal Data Protection Principles}

13. This Act operates in addition to and not in derogation from the protection of personal data under the Personal Data Protection Act 2010.

\section{Other laws}

14. Nothing in this Act operates in derogation from the provisions of the Official Secrets Act 1972, or of the Public Order (Preservation) Act 1958. 


\section{BIBLIOGRAPHY}

\section{A Legislation}

$1 \quad$ New Zealand

Bill of Rights Act 1990.

Broadcasting Act 1989.

Crimes Act 1961.

Crown Entities Act 2004.

Defamation Act 1952.

Harassment Act 1997.

Postal Services Act 1998.

Privacy Act 1993.

Residential Tenancies Act 1986.

Search and Surveillance Act 2012.

Summary Offences Act 1981.

$2 \quad$ Malaysia

Banking and Financial Institutions Act 1989.

Betting Ordinance 1953.

Broadcasting Act 1988.

Child Act 2001.

Civil Law Act 1956.

Communications and Multimedia Act 1998. 
Consumer Protection Act 1999.

Contracts Act 1950.

Courts of Judicature Act 1964.

Credit Reporting Agencies Act 2010.

Criminal Procedure Code.

Defamation Act 1957.

Digital Signature Act 1997.

Federal Constitution.

Films (Censorship) Act 1952.

Hire Purchase Act 1967.

Houses of Parliament (Privileges and Powers) Act .

Human Rights Commission Act 1999.

Indecent Advertisements Act 1953.

Internal Security Act 1960.

Judicial Proceedings (Regulation of Reports) Act 1962.

Legal Profession Act 1976.

Limitation Act 1963.

Lotteries Act 1952.

Medicines (Advertisement and Sale) Act 1956.

Moneylenders Act 1951.

National Land Code 1965.

Official Secrets Act 1972.

Penal Code.

Perbadanan Kemajuan Filem Nasional Malaysia Act 1981. 
Personal Data Protection Act 2010.

Police Act 1967.

Printing Presses and Publications Act 1984.

Protected Areas and Protected Places Act 1959.

Public Order (Preservation) Act 1958.

Rules of the High Court 1980.

Sale of Goods Act 1957.

Security Offences (Special Measures) Act 2012.

Sedition Act 1948.

Specific Relief Act 1950.

Subordinate Court Act 1948.

Telecommunications Act 1950.

3 United Kingdom

Children and Young Persons Act 1933.

Data Protection Act 1998.

Human Rights Act 1998.

Protection from Harassment Act 1997.

B Cases

$1 \quad$ New Zealand

Andrews v Television New Zealand Ltd [2009] 1 NZLR 220 (HC).

Bradley $v$ Wingnut Films Ltd [1993] 1 NZLR 415 (HC). 
Brooker v Police [2007] NZSC 30; [2007] 3 NZLR 91; [2007] 23 CRNZ 346 (SCNZ).

Brown v Attorney-General [2006] DCR 630; [2006] NZAR 552 (DC).

C v Holland [2012] 3 NZLR 672.

Hosking v Runting [2003] 3 NZLR 385 (HC).

Hosking v Runting [2005] 1 NZLR 1; [2004] 7 HRNZ 301 (CA).

$R v$ Jefferies [1994] 1 NZLR 290; [1993] 1 HRNZ 478 (CA).

Rogers v Television New Zealand Ltd [2007] NZSC 91; [2008] 2 NZLR 277 (SCNZ).

Television New Zealand Ltd v Rogers [2007] 1 NZLR 156 (CA).

Tuckerv News Media Ownership Ltd [1986] 2 NZLR 716 (HC).

$2 \quad$ Australia

Australian Broadcasting Corporation v Lenah Game Meats Pty Ltd [2001] 208 CLR 199.

Theophanus v Herald \& Weekly Times Ltd [1994] 182 CLR 104.

$3 \quad$ India

Kharak Singh v State of Uttar Pradesh [1963] AIR 1295 (SC).

Govind v State of Madhya Pradesh [1975] AIR 1378 (SC).

R Rajagopal v State of Tamil Nadu (1994) 6 SCC 632.

People's Union for Civil Liberties v Union of India (1997) 1 SCC 318.

Mr. Xv Hospital Z (2003) 1 SCC 500 (SC).

Naz Foundation v Government of NCT of Delhi WP(C) No. 7455/2001 (2 July 2009).

Vishaka v State of Rajasthan (1997) 6 SCC 241. 
$4 \quad$ Malaysia

Abu Hassan Bin Abd Jamal v Public Prosecutor [1994] MLJU 223 (HC).

Alfred Templeton \& Ors $v$ Low Yat Holdings Sdn Bhd \& Anor [1989] 2 MLJ 202.

Azman Bin Mohd Yussof \& Ors v Vasaga Sdn Bhd [2001] 6 MLJ 217.

Badan Peguam Malaysia v Kerajaan Malaysia [2008] 1 CLJ 521.

Chen Yue Kiew (F) v Angkasamas Sdn Bhd [2003] 4 MLJ 365.

Cheng Hang Guan \& Ors v Perumahan Farlim (Penang) Sdn Bhd \& Ors [1993] 3 MLJ 352.

Choa Choon Neoh v Spottiswoode (1869) 1 Ky 216.

Chong Siew Chiang v Chua Ching Geh \& Anor [1995] 1 MLJ 551.

Chung Khiaw Bank Ltd v Hotel Rasa Sayang Sdn Bhd \& Anor [1990] 1 MLJ 356.

Danaharta Urus Sdn Bhd v Kekatong Sdn Bhd (Attorney General Malaysia) [2004] 2 MLJ 257.

Dato’ Menteri Othman Baginda v Dato' Ombi Syed Alwi bin Syed Idrus [1981] 1 MLJ 29.

Dato' Seri Anwar Ibrahim v The New Straits Times Press (M) Sdn Bhd \& Anor [2010] 2 MLJ 42 (HC).

Dr Bernadine Malini Martin v MPH Magazines Sdn Bhd \& Ors [2006] 2 CLJ 1117.

Electrical Industry Workers Union \& Ors v Makonka Electronics Sdn Bhd [1996] MLJU 387 (HC).

HMO Pacific Sdn Bhd v Dr Johari Bin Muhamad Yusup [1997] MLJU 286 (HC).

Hong Leong Equipment Sdn Bhd v Liew Fook Chuan [1996] 1 MLJ 481.

IJM Corporation Bhd v Harta Kumpulan Sdn Bhd [2007] 8 MLJ 591 (HC).

In the Goods of Abdullah (1835) 2 Ky Ecc 8. 
Jamil bin Harun v Yang Kamsiah \& Anor [1984] 1 MLJ 217 (PC).

JB Jeyaretnam v Goh Chok Tong [1985] 1 MLJ 334; [1984] 1 LNS 139.

Julaika Bivi v Mydin [1961] MLJ 310.

K Mahunaran v Osmond Chiang Siang Kuan [1996] 5 MLJ 293.

Karuppannan v Balakrishnen (Chong Lee Chin, Third Parties) [1994] 3 MLJ 584.

Kong Lai Soo v Ho Kean [1973] 2 MLJ 250.

Lee Ewe Poh v Dr Lim Teik Man \& Anor [2011] 1 MLJ 835 (HC).

Lee Kwan Woh v PP [2009] 5 CLJ 631 (FC).

Lew CherPhow @ Lew Cha Paw \& Ors v Pua Yong Yong \& Anor [2011] MLJU 1195 (HC).

Maslinda bt Ishak v Mohd Tahir bin Osman \& Ors [2009] 6 MLJ 826 (COA).

Ong Cheng Neo v Yeap Cheah Neo (1875) LR 6 PC 381.

Ong Koh Hou v Perbadanan Bandar \& Anor [2009] 8 MLJ 616 (HC).

Pihak Berkuasa Negeri Sabah v Sugumar Balakrishnan. [2002] 3 MLJ 72 (FC).

Public Prosecutor v Lee Sin Long [1949] 1 MLJ 51.

Schmidt Scientific Sdn Bhd v Ong Han Suan [1997] 5 MLJ 632 (HC).

Seong Fatt v Dunlop Malaysia Industries Sdn Bhd [1984] 1 MLJ 286.

Shaharuddin bin Mohammad v Malayan Banking Bhd [2011] 7 MLJ 589.

Shamim Reza v Public Prosecutor [2009] 6 CLJ 93.

Sin Heap Lee-Marubeni Sdn Bhdv Yip Shou Shan [2005] 1 MLJ 515.

Sivarasa Rasiah v. Badan Peguam Malaysia \& Anor (2010) 3 CLJ 507 (FC).

Solid Gold Publishers Sdn Bhd v Chan Wee Ho \& Ors [2002] 3 MLJ 310. 
Sri Inai (Pulau Pinang) Sdn Bhdv Yang Yit Swee [2003] 1 MLJ 273.

Sugumar Balakrishnan v Pengarah Imegresen Negeri Sabah \& Anor [1998] 3 MLJ 289 (CA).

Tan Tek Seng v Suruhanjaya Perkhidmatan Pendidik \& Anor [1996] 1 MLJ 481.

Tun Datuk Patinggi Haji Abdul Rahman Ya'kub v Bre Sdn Bhd \& Ors [1996] 1 MLJ 393; [1995] 1 LNS 304.

Ultra Dimension Sdn Bhd v Kook Wei Kuan [2004] 5 CLJ 285 (HC).

Worldwide Rota Dies Sdn Bhdv Ronald Ong Cheow Joon [2010] 8 MLJ 297.

Yong Joo Lin v Fung Poi Fong [1941] MLJ Rep 54.

$5 \quad$ United Kingdom

$A v B$ plc [2003] QB 195.

AG v Guardian Newspaper Ltd (No 2) [1990] 1 AC 109.

Argyll v Argyll [1967] Ch 302.

Associated Newpapers Ltd v HRH Prince of Wales [2008] Ch 57; [2007] 2 AllER 139; [2007] 3 WLR 222; [2006] EWCA Civ 1776.

Associated Newspapers Ltd v HRH Prince of Wales [2006] EWCA Civ 1776.

Attorney General v Leveller Magazine [1979] AC 440.

Bernstein v Skyviews Ltd [1978] QB 479.

Campbell v MGN Ltd [2004] UKHL 22; [2004] 2 AC 457 (HL).

Coco v AN Clark (Engineers) Limited [1969] RPC 41.

Douglas and other v Hello! Ltd [2002] 2 WLR 992; [2001] QB 967.

Douglas v Hello! Ltd (No 3) [2006] QB 125.

Entick v Carrington (1765) St Trials 1029.

Gordon Kaye v Andrew Robertson [1991] FSR 62 (CA). 
Green v DB Group Services (UK) Ltd [2006] EWHC 1898 (QB).

Hellewell v Chief Constable of Derbyshire [1995] 1 WLR 804.

Hipgrave v Jones [2004] EWHC 2901 (QB).

Hunter v Canary Wharf Ltd [1931] AC 33.

Jacklyn Adeniji v Newham Council (October 2001, High Court).

Kaye v Robertson [1991] FSR 62.

Khoransandjian v Bush [1993] 3 All ER 669.

Lord Browne of Madingley v Associated Newspaper Ltd [2008] QB 103 (CA).

Malone v Metropolitan Police Commissioner [1979] Ch 344.

McKennitt v Ash [2006] EWCA Civ 1714.

Mosley v News Group Newspapers Ltd [2008] EMLR 679 (QB).

Murray v Express Newspaper Plc [2008] EWCA Civ 446.

Pollard v Photographic Co (1888) 40 Ch D 345.

Prince Albert v Strange [1849] ER 1171.

$R v$ Khan [1997] AC 558.

Rookes v Barnard [1964] AC 1129.

Schering Chemicals v Falkman [1981] All ER 321.

Scott $v$ Scott [1913] AC 417.

Seager v Copydex Ltd [1967] 1 WLR 923.

Stephen v Avery [1988] Ch 449.

Tolley v Fry \& Sons Ltd [1931] AC 33.

Wainwright v Home Office [2003] UKHL 53; [2004] 2 AC 406 (HL); [2002] 3 WLR 405 (CA).

Wilkinson v Downton [1897] 2 QB 57. 
Williams v Settle [1960] 1 WLR 1072.

Venables and Thompson $v$ Newsgroup Newspaper and Associated Newspaper Ltd [2001] 2 WLR 1038; [2001] 1 All ER 908.

Vidal Hall and Ors v Google Inc [2014] EWHC 13 (QB).

6 Other jurisdictions

Axen v Germany [1984] 6 EHRR 195.

Daubney v Cooper (1829) 109 ER 438.

Earl Spencer v United Kingdom [1998] 25 EHRR CD 105.

Niemietz v Germany [1992] 16 EHRR 97.

Peck v United Kingdom [2003] 36 EHRR 41.

Pretty v United Kingdom [2002] 35 EHRR 1.

Richmond Newspapers Inc v Virginia 448 (US) 555.

Time Inc v Hill [1967] 385 US 374.

von Hannover [2005] 40 EHRR 1.

\section{Books}

A, A Sheridan and Groves, HE The Constitution of Malaysia (4th ed, Malayan Law Journal Pte Ltd, Singapore, 1987).

Ali, Abdullah Yusuf The Holy Quran: Text, Translation and Commentary (Amana Corporation, USA, 1989).

al-Jawziyyah, Ibn Qayyim Turuq al-hukmiyyah translated by Ala'eddin Kharoffa (International Law Book Services, Kuala Lumpur, 2000).

Allen, Anita L Uneasy Access: Privacy for Women in a Free Society (Random and Littlefield, Totowa, 1988).

Aplin, Tanya, et al Gurry on Breach of Confidence: The Protection of Confidential Information (2nd ed, Oxford University Press, 2012). 
Bainbridge, David Data Protection Law (2nd ed, XPL Publishing, Great Britain, 2005).

Bari, Abdul Aziz Malaysian Constitution: A Critical Introduction (The Other Press, Kuala Lumpur, 2003).

Beardsley, Elizabeth "Privacy: Autonomy and Selective Disclosure" in (eds) JR Pennock and JW Chapmans Privacy and Personality (Transaction Publishers, USA, 1971).

Bellotti, V and Sellen, A Design for Privacy in Ubiquitous Computing Environments (Kluwer Academic Publishers, 1993).

Berlin, Isaiah Four Essays on Liberty (Oxford University Press, London, 1969).

Boruch, RF "Privacy of Individuals in Social Research: Confidentiality" in The International Encyclopedia of the Social and Behavioural Sciences (Elsevier Science, Oxford, 2001).

Burckhardt, T Art of Islam: Language and Meaning (Westerham Press, Edenbridge, Kent, 1976).

Burrows, John "Invasion of Privacy" in Stephen Todd (ed) The Law of Torts in New Zealand (6th ed, Thomson Reuters, Wellington, 2013).

Burrows, John and Cheer, Ursula Media law in New Zealand (Oxford University Press, New Zealand, 2005).

Butler, Andrew and Butler, Petra The New Zealand Bill of Rights Act: A Commentary (LexisNexis, Wellington, 2005).

Cane, P The Anatomy of Tort Law (Oxford, Hart Publishing, 1997).

Clayton, Richard and Tomlinson, Hugh (eds) The Law of Human Rights (2nd ed, Oxford University Press, Oxford, 2009).

Cohen, Stanley A Invasion of Privacy: Police and Electronic Surveillance in Canada (The Carswell Company Ltd, Toronto, Canada, 1983).

Cooley, Thomas M A Treatise on the Law of Torts (2nd ed, Callaghan, Chicago, 1888).

Dugdale, Anthony M Clark \& Lindsell on Torts (20th ed, Sweet \& Maxwell, London, 2010). 
E Barendt "Privacy as a Constitutional Right and Value" in B Markesinis (ed) Protecting Privacy (Oxford University Press, 1999).

Elliot, Catherine and Quinn, Frances Tort Law (7th ed, Pearson Longman, England, 2009).

Feldman, David Civil Liberties and Human Rights in England and Wales (2nd ed, Oxford University Press, New York, 2002).

Fenwick, Helen and Phillipson, Gavin Media Freedom under the Human Rights Act (Oxford University Press, 2006).

Fenwick, Helen Civil Liberties and Human Rights (Routledge-Cavendish, New York, 2007).

Finn, Jeremy and Todd, Stephen (eds) Law, Liberty, Legislation (LexisNexis, New Zealand, 2008).

Fitzgerald, Brian and Fitzgerald, Anne Cyberlaw: Cases and Materials on the Internet, Digital Intellectual Property and Electric Commerce (LexisNexis Butterworths, Australia, 2002).

Francis Gurry Breach of Confidence (Oxford University Press, Clarendon, 1984).

Fred H Cate Privacy in the Information Age (Brookings Institution Press, Washington, 1997).

Gibson, Dale (ed) Aspects of Privacy Law: Essays in Honour of John M Sharp (Butterworths, Toronto, 1980).

Gross, Hyman Privacy - Its legal protection: Based on Original Almanac (Oceana Publications, New York, 1976).

Hamzah, Wan Arfah and Bulan, Ramy An Introduction to the Malaysian Legal System (Oxford Fajar Sdn Bhd, Malaysia, 2003).

HE Groves "Kebebasan Asasi Dalam Perlembagaan Persekutuan Malaysia" in M Suffian, HP Lee and FA Trindade Perlembagaan Malaysia Perkembangannya: 1957-1977 (Penerbit Fajar Bakti Sdn Bhd, Malaysia, 1983).

Hickling, RH Malaysian Law: An Introduction to the Concept of Law in Malaysia (Pelanduk Publication, Malaysia, 2001). 
Hixson, Richard F Privacy in a Public Society: Human Rights in Conflict (Oxford University Press, New York, 1987).

Hoffman, David The Impact of the UK Human Rights Act on Private Law (Cambridge University Press, UK, 2011).

Ibn Qudamah and Muwaffaq al-Din al Maqdisi al-Mughni (Riyadh, AlMaktabah al Haditsah, 1984).

Ibrahim, Ahmad and Joned, Ahilemah The Malaysian Legal System (Dewan Bahasa dan Pustaka, Malaysia, 1987).

Jay, Rosemary and Hamilton, Angus Data Protection Law and Practice (2nd ed, Sweet \& Maxwell, London, 2003).

Jay, Rosemary Data Protection Law and Practice (3rd ed, Sweet \& Maxwell, London, 2007).

Jon L Mills Privacy the lost right (Oxford University Press, 2008).

Kamali, Mohammad Hashim Principles of Islamic Jurisprudence (Cambridge, UK, Islamic Texts Society, 2003).

Kenyon, Andrew T and Richardson, Megan New Dimensions in Privacy Law: International and Comparative Perspectives (Cambridge University Press, UK, 2006).

Kinley, David The European Convention on Human Rights: Compliance without Incorporation (University Press, Cambridge, England, 1993).

Lee Mei Pheng General Principles of Malaysian Laws (5th ed, Oxford Fajar Sdn Bhd, Malaysia, 2005).

Lilian Edwards and Charlotte Waelde Law and the Internet Regulating Cyberspace (Hart Publishing, Oxford, England, 1997).

M David Lepofsky Open Justice: The Constitutional Right to Attend and Speak About Criminal Proceedings (Butterworths, Toronto, 1985).

MA, Wu The Malaysian Legal System (3rd ed, Pearson Malaysia Sdn Bhd, Kuala Lumpur, 2007).

Mahdi Zahraa Research Methods for Law Posgraduate Overseas Students (Univision Press, Kuala Lumpur, 1998). 
Mark Warby QC, Nicole Moreham \& Iain Christie Tugendhart and Christie The Law of Privacy and the Media (eds) (2nd ed, Oxford University Press, Oxford, 2011).

Michael Tugendhat QC and Ian Christie (eds) Tugendhart and Christie The Law of Privacy and the Media (Oxford University Press, Oxford, 2002).

Miller, Arthur R The Assault on Privacy: Computers, Data Banks, and Dossiers (University of Michigan Press, Ann Arbor, 1971).

Mitchell G Architecture of the Islamic World (Thames and Hudson, London, 1987).

Mohamad Tajuddin MR Essays on Architecture Volume 1 (Universiti Teknologi Malaysia, Johor, 1997).

MP Jain Indian Constitutional Law (4th ed, LexisNexis Butterworths, 2001). Murphy, John Street on Torts (12th ed, Oxford University Press, 2007).

Nicholas J Mullany Torts in the Nineties (LBC Information Services, Sydney, 1997).

Penk, Stephen and Tobin, Rosemary (eds) Privacy Law in New Zealand (Brookers Ltd, Wellington, 2010).

Posner, Richard A The Economics of Justice (Harvard University Press, Cambridge, 1981).

Rishworth, Paul et al The New Zealand Bill of Rights (Oxford University Press, Melbourne, 2003).

Rogers, WVH Winfield \& Jolowicz on Tort (18th ed, Sweet \& Maxwell, 2010).

Roth, Paul Privacy Law and Practice Case Note 1994-2005 (LexisNexis, Wellington, 2007).

S Jayakumar Constitutional Law Cases from Malaysia and Singapore (2nd Malayan Law Journal Pte Ltd, Singapore, 1976).

Schoeman, Ferdinand D "Privacy: Philosophical Dimensions of the Literature" in Philosophical Dimensions of Privacy: An Anthology (Cambridge University Press, Cambridge, 1984).

Schoeman, Ferdinand D Privacy and Social Freedom (Cambridge University Press, New York, 1992). 
Talib, Norchaya Law of Torts in Malaysia (Sweet \& Maxwell Asia, Malaysia, 2010).

Todd, Stephen The Law of Torts in New Zealand (6th ed, Thomson Reuters, Wellington, 2013).

Tomlinson, Hugh (ed) Privacy and the Media: The Developing law (Matrix Chambers Ltd, 2002).

Wacks, Raymond Privacy and Media Freedom (Oxford University Press, United Kingdom, 2013).

Wacks, Raymond Personal Information: Privacy and the Law (Oxford University Press, Great Britain, 1989).

Wacks, Raymond Privacy and Press Freedom (Blackstone Press, London, 1995).

Wacks, Raymond Protection of Privacy (Sweet \& Maxwell, Great Britain, 1980).

Westin, AF Privacy and Freedom (Bodley Head Ltd, London, 1970).

Wright, Jane Tort Law and Human Rights (Hart Publishing, Oxford, 2001).

Yaqin, Anwarul Legal Research and Writing (LexisNexis, Malaysia, 2007).

Ziegler, Katja S (ed) Human Rights and Private Law: Privacy as Autonomy (Hart Publishing, Oxford, 2007).

\section{Journal Articles and Essays in Edited Texts}

A Aziz, Shamrahayu "The Malaysian Legal System: The Roots, The Influence and the Future" [2009] 3 MLJ xcii.

Ahmad, Nehaluddin "Privacy and the Indian Constitution: A Case Study of Encryption" (1997) 2 (4) AALL Spectrum 8.

Alshech, Eli "Do not Enter Houses Other than Your Own: The Evolution of the Notion of A Private Domestic Sphere in Early Sunni Islamic Thought" (2004) 11(3) 291. 
Alshech, Eli "Out of Sight and Therefore Out of Mind: Early Sunni Islamic Modesty Regulations and the Creation of Spheres of Privacy" (2007) 66 (4) Journal of Near Eastern Studies 267.

Altman, Irwin "Privacy - A Conceptual Analysis" (1976) 8 Environment and Behaviour 7.

Altman, Irwin "Privacy Regulation: Culturally Universal or Culturally Specific?” (1977) 33 Journal of Social Issues 66.

Altman, Irwin "Privacy Regulation: Culturally Universal or Culturally Specific?” (1977) 33 Journal of Social Issues 66.

Aplin, Tanya "The Relationship between Breach of Confidence and 'the Tort of Misuse of Private Information'” (2007) 18(2) King’s Law Journal 329.

Arden, “The Future Law of Privacy” (1998-1999) 9 King College LJ 1 at 5.

Ayub, Zainal Amin and Mohamed Yusoff, Zuryati "Leave me Alone!: Syariah v Civil Law" [2007] MLJ xcix.

Azmi, Ida Madieha "E-Commerce and Privacy Issues: An Analysis of the Personal Data Protection Bill” (2002) 16 IRLCT 326.

Azmi, Ida Madieha "Personal data protection law: The Malaysian experience" (2007) 16(2) Information \& Communications Technology Law 125.

Berween, $M$ "The Fundamental of Human Right: An Islamic Perspective" (2002) 6(1) The International Journal of Human Rights 61.

Bloustein, Edward "Privacy as an Aspect of Human Dignity: An Answer to Dean Prosser" (1964) 39 NYUL Rev 962.

Burrows, John "Invasion of Privacy - Hosking and Beyond" [2006] NZ Law Rev 389.

Burrows, John "The News Media and the Law" (2003) 9 Canterbury Law Review 229.

Cheer, Ursula "The Future of Privacy Recent Legal Developments in New Zealand [2007] 13 Canterbury L Rev 169.

Collins, Hugh "The Decline of Privacy in Private Law" (1987) 14 (1) Journal of Law and Society 91. 
Daniel J Solove “Conceptualizing Privacy" (2002) 90(4) California L Rev 1087.

Deva, Surya "The State of Affirmative Action amidst Privatisation: Some Critical Reflections" in Swati Deva (ed) Law and (In)equalities: Contemporary Perspectives (Easter Book Company, India, 2010).

Dhaliwal, Harmindar Singh "Tests of Defamatory Matter - New Mindset Required?” [2003] 2 MLJ i.

El Islamy, Huriyyah "Information Privacy in Malaysia: A Legal Perspective" (2005) 1 MLJ xxv.

Ely, John Hart "The Wages of Crying Wolf: A Comment on Roe v Wade" (1973) 82 Yale LJ 920.

Evans, Katrine "Show Me the Money: Remedies under the Privacy Act" (2005) 36 VUWLR 475.

Fenwick, Helen and Phillipson, Gavin "Confidence and Privacy: A ReExamination” (1996) 55 Cambridge LJ, 447.

Fried, Charles "Privacy” (1968) 77(3) Yale LJ 475.

Garrett, Roland “The Nature of Privacy” (1974) 18 Philosophy Today 274.

Gavin Phillipson "Max Moslley goes to Strasbourg: Article 8, Claimant Notification and Interim Injunction” (2009) 1 Journal of Media Law 73.

Gavison, Ruth "Privacy and the Limits of Law" (1980) 89 Yale LJ 421.

Gerety, Tom "Redifining Privacy" (1977) 12 Harvard Civil Rights - Civil Liberties Law Review 236.

Gopal, Mohan "English Law in Singapore: The Reception that Never Was" [1983] 1 MLJ xxv.

Gross, Hyman "The Concept of Privacy (1967) 42 NYUL Rev 34.

Hare, Ivan "Vertically challenged: Private Parties, Privacy and the Human Rights Act" (2001) EHRLR 526.

Hashim, Ahmad Hariza et al "Visual privacy and family intimacy, A case study of Malay inhabitants living in two storey low-cost terrace housing" (2006) 33 Environment and Planning B: Planning and Design 301. 
Hayat, MA "Privacy and Islam: From the Quran to Data Protection in Pakistan" (2007) 16 (2) Information and Communications Technology Law 137.

Hunt, Chris DL "Conceptualizing Privacy and Elucidating its Importance: Foundational Considerations for the Development of Canada's Fledgling Privacy Tort” (2011) 37(1) Queen's LJ 167.

Hunt, Chris DL "Privacy in the Common Law: A Critical Appraisal of the Ontario Court of Appeal's Decision in Jones v Tsige" 92012) 37(2) Queen's LJ 661.

Hunt, M “The 'Horizontal Effect' of the Human Rights Act (1998) PL 423.

Kadivar, Mohsen "An Introduction to the Public and Private Debate in Islam" (2003) 70(3) Social Research 659.

Khaw, Lake Tee "Towards a personal data protection regime in Malaysia" (2002) JMCL 11.

Kling, Zainal "The Malay family: Beliefs and realities" (1995) 26 (1) Journal of Comparative Family Studies 43.

Lindsay, David "An Exploration of the Conceptual Basis of Privacy and the Implications for the Future of Australian Privacy Law" (2005) 29(1) Melbourne University LR 131.

Lord Neuberger of Abbotsbury "Privacy and Freedom of Expression: A Delicate Balance" (2011) 1 LNS(A) lxxii.

Mohamed Yusoff, Zuryati "The Malaysian Personal Data Protection Act 2010: A Legislation Note” (2011) 9 NZJPIL 119.

Mohamed Yusoff, Zuryati "Constitutional Protection of Privacy in Malaysia: A case study" [2011] 1 LNSA 1xxix.

Moreham, NA “Privacy in Public Places” (2006) 65 Cambridge LJ 60.

Moreham, NA "Privacy in the common law: a doctrinal and theoretical analysis" (2005) 121 LQR 628.

Moreham, NA "Privacy Rights" in Mark Warby QC, Nicole Moreham and Iain Christie (eds) Tugendhat \& Christie The Law of Privacy and the Media (Oxford University Press, 2011). 
Moreham, NA "Protection against Intrusion" in Mark Warby QC, Nicole Moreham and Iain Christie Tugendhart and Christie The Law of Privacy and the Media (eds) (2nd ed, Oxford University Press, Oxford, 2011).

Moreham, NA "Recognising Privacy in England and New Zealand" (2004) Cambridge LJ 555.

Moreham, NA "The Right to Respect for Private Life in the European Convention on Human Rights: A Re-examination" (2008) EHRLR Issue 1, 44.

Moreham, NA "Why is Privacy Important? Privacy, Dignity and Development of the New Zealand Breach of Privacy Tort" in Jeremy Finn and Stephen Todd (eds) Law, Liberty, Legislation (LexisNexis NZ Limited 2008).

Morgan, Jonathan in "Privacy, Confidence and Horizontal Effect: "Hello" Trouble" (2003) 62 Cambridge LJ 444.

Munir, Abu Bakar "Personal Data Protection Act: Doing Well By Doing Good" [2012] 1 MLJ lxxxiii.

$\mathrm{Ng}$-Loy Wee Loon "Emergence of a right to privacy from within the law of confidence?” (1996) 18(5) European Intellectual Property Rev 30.

Pannik, David and Lester, Anthony "The Impact of the Human Rights Act on Private Law: The Knight's Move" (2000) 116 LQR 380.

Parent, WA “A New Definition of Privacy for the Law" (1983) 2(3) Law and Philosophy 305.

Parent, WA "Privacy, Morality, and the Law" (1983) 12(4) Philosophy and Public Affairs 269.

Parker, Richard B “A Definition of Privacy” (1974) 27 Rutgers Law Rev 275.

Penk, Stephen "Future Directions and Issues" in Stephen Penk and Rosemary Tobin (eds) Privacy Law in New Zealand (Brookers, Wellington, 2010).

Phillipson, Gavin "Max Moslley goes to Strasbourg: Article 8, Claimant Notification and Interim Injunction" (2009) 1 Journal of Media Law 73.

Phillipson, Gavin "The Human Rights Act, 'Horizontal Effect' and the Common Law: a Bang or a Whimper?” (1999) 62 MLR 824. 
Phillipson, Gavin "Transforming Breach of Confidence? Towwards a Common Law Right of Privacy under the Human Rights Act" (2003) 66 Modern L Rev 726.

Plowden, Philip "Right to Privacy - Michael Douglas, Catherine Zeta-Jones, Northen and Shell plc v Hello Ltd." (2001) 6 Journal of Civil Liberties 57.

Posner, Richard A The Economics of Justice (Harvard University Press, Cambridge, 1981).

Powers, Madison "A Cognitive Access Definition of Privacy" (1996) 15(4) Law and Philosophy 369.

Prosser, William L "Privacy” (1960) 48(3) California Law Rev 383.

R Singh "Privacy and the Media after the Human Rights Act" (2000) EHRLR 712 .

Richard B Parker “A Definition of Privacy” (1974) 27 Rutgers Law Rev 275.

Roth, Paul "What is 'Personal Information'?” (2000) 20 NZULR 40.

Saleem Faruqi, Shad "Free Speech and the Constitution" [1992] 4 CLJ lxiv.

Schoeman, Ferdinand "Privacy: Philosophical Dimensions" (1984) 21(3) American Philosophical Quarterly 199.

Shuaib, Farid Sufian "Towards Malaysian Common Law: Convergence Between Indigenous Norm and Common Law Methods" (2009) Jurnal Undang-undang 158.

Singh, Mahendra P "Fundamental Rights, State Action and Cricket in India" (2006) 13 Asia Pacific Law Review 203

Solove, Daniel J "Conceptualizing Privacy" (2002) 90(4) California L Rev 1087.

Stone, Adrienne "Rights, Personal Rights and Freedoms: The Nature of the Freedom of Political Communication" (2001) 25 Melbourne University Law Rev 374.

Stone, Adrienne "Rights, Personal Rights and Freedoms: The Nature of the Freedom of Political Communication" (2001) 25 Melbourne University Law Rev 374. 
Stone, Adrienne "The Common Law and The Constitution: A Reply" (2002) 26 Melbourne University Law Rev 646.

Taseff, Rebecca "The Protection of Personal Privacy: The Differences Between A Privacy Tort and The Action for Breach of Confidence" (2005) 10 Media and Arts Law Rev 208.

Taylor, Greg "Why is There no Common Law Right of Privacy?" (2000) 26 Monash University Law Rev 235.

Taylor, Greg "Why Should the Common Law Be Only Indirectly Affected by Constitutional Guarantees" (2002) 26 Melbourne University Law Rev 623.

Taylor, Greg and Wright, David "Australian Broadcasting Corporation v Lenah Game Meats: Privacy, Injunctions and Possums: An Analysis of the High Court's Decision” (2002) 26 Melbourne University Law Rev 702.

Tobin, Rosemary “Invasion of Privacy” [2000] NZLJ 216.

Tobin, Rosemary "Privacy: one step forward, two steps back!" [2003] NZLJ 256.

Wacks, Raymond "The Poverty of "Privacy"' (1980) 96 LQR 73.

Warren, SD and Brandeis, LD “The right to privacy" (1890)(4) Harv Law Rev 193.

Whitman, James Q "The Two Western Cultures of Privacy: Dignity Versus Liberty" (2004) 113 Yale LJ 1151.

Winfield, P "Privacy” (1931) LQR 23.

Yi, CB and Ok, KJ “Korea's Personal Information Protection Laws" (2003) PLPR 8.

Young, Alison L "Mapping Horizontal Effect" in David Hoffman (ed) The Impact of the UK Human Rights Act on Private Law (Cambridge University Press, UK, 2011).

\section{E Law Reform, Reports and Issues Paper}

Australian Law Reform Commission, Issues Paper 43: Serious Invasions of Privacy in the Digital Era (2013). 
Australian Law Reform Commission, Report 108: For Your Information: Australian Privacy Law and Practice (2008).

Ireland Privacy Bill 2006

http://www.oireachtas.ie/documents/bills28/bills/2006/4406/b4406s.pdf

New South Wales Law Reform Commission, Report 120: Invasion of Privacy (2009).

New Zealand Law Commission Study Paper Review of Privacy Act 1993 Review of the Law of Privacy Stage 4 (NZLC, Wellington, 2010).

New Zealand Law Commission Report Invasion of Privacy: Penalties and Remedies: Review of the Law of Privacy Stage 3 (NZLC, Wellington, 2010).

Victorian Law Reform Commission, Surveillance in Public Places: Final Report 18 (2010).

\section{F Theses, Working, Research, Seminar Papers}

Abdul Hamid Mohamed "Harmonization of Common Law and Shariah in Malaysia: A Practical Approach" (Abd Razzaq Al-Sanhuri Lecture, Islamic Legal studies Program, Harvard Law School, 6 November 2008).

Abu Bakar Munir "Data Protection Law: Too little, too late?" (Public Lecture 2009, Universiti Malaya, 4 August 2009).

Australian Law Reform Commission, Report 108: For Your Information: Australian Privacy Law and Practice (2008).

Esme R Poppleton “Towards A Privacy Law - Key Influences” (PhD Thesis, University of Exeter, 2006).

Foong Cheng Leong "Right to privacy in Malaysia: Do we have it" The Malaysian Insider (Malaysia, 21 Februari 2011).

Graham Greenleaf "Limitations of Malaysia's data protection Bill” (2010) 104 Privacy Laws and Business International Newsletter 1.

Graham Greenleaf "The Naz Foundation Case: Delhi High Court Ruling Expands India's Constitutional Privacy Rights" (2009) 100 Privacy Laws \& Business International Newsletter, 24. 
Haidar Dziyauddin “ A Comparative Study of Freedom of Expression ang Right to Privacy in Relation to the Press in Malaysia and the United Kingdom” (PhD Thesis, University of Newcastle Upon Tyne, 2005).

Hurriyah El-Islamy "Privacy as freedom of Private Life: the Re-examination of the Concept, the Scope and its Analysis and Comparison with the Law of Confidence in the UK and Malaysia" (PhD Thesis, University of Strathclyde, 2006).

Ida Madieha Azmi "E-Commerce and Privacy Issues: An Analysis of the Personal Data Protection Bill" (17 $7^{\text {th }}$ BILETA Annual Conference, Free University, Amsterdam, 5-6 April 2002).

JF Burrows and Newspaper Publishers' Association of New Zealand "News media law in New Zealand" (Newspaper Publishers' Association of NZ, Wellington, 1980).

JF Burrows and others "Media law" (New Zealand Law Society, Wellington, 2003).

Legal Research Foundation Seminar "Media law" (Legal Research Foundation, Auckland, 2006).

Martin Heite "Privacy, Constitutions and the Law of Torts: A Comparative and Theoretical Analysis of Protecting Personal Information Against Dissemination in New Zealand, the UK and the USA" (PhD Thesis, University of Canterbury, 2008).

Minister of Justice A Bill of Rights for New Zealand: A White Paper (Department of Justice, Wellington, 1985).

Mohd Bahrin Othman "A Critical Study of the Viability of the Personal Data Protection Legal Framework in Malaysia: With Special reference to the EU and the UK Frameworks" (PhD Thesis, Universiti Teknologi MARA, 2009.)

Ursula Cheer "Reality and Myth: The New Zealand Media and the Chilling Effect of Defamation Law" (PhD Thesis, University of Canterbury, 2008).

\section{G Newspaper Articles and Media Release}

"Elizabeth Wong just wants to get back to work" The Star Online (Malaysia, 17 April 2009). 
"Nasha spy camera case: Supervisor loses appeal" The Star Online (Malaysia, 6 October 2008); See also "Judges send man who fixed spy camera in model's home to prison" The Star Online (Malaysia, 7 October 2008).

"Parliament: Personal Data Protection Bill Passed" The Star Online (Malaysia, 5 April 2010).

"Police launch probe, warn of penalties for having video" The Star Online (Malaysia, 2 January 2008).

Christina Tan "Eli Wong back at work" The Star Online (Malaysia, 16 April 2009).

Foong Cheng Leong "Personal data and the law" The Star Online (Malaysia, 5 August 2010).

M Mageswari "High Court dismisses breach of privacy claims against Celcom Axiata" The Star Online (Malaysia, 17 March 2012).

M Mageswari “Nurin's dad reaches out-of-court settlement in negligence suit against government” The Star Online (Malaysia, 29 November, 2010).

Rais Yatim "Protecting your personal data" The Star Online (Malaysia, 12 February 2012).

Yeng Ai Chun "Personal Data Protection: Government has own mechanism" The Star Online (Malaysia, 15 July 2009).

Zulkifli Abd Rahman "Bill requiring credit-reporting agencies to obtain consent passed" The Star Online (Malaysia, 20 April 2010).

\section{H Internet Resources}

<http://www.judiciary.gov.uk/Resources/JCO/Documents/Reports/superinjunction-report-20052011.pdf $>$.

$<$ http://www.statistics.gov.my/portal/download_Population/files/census2010/ Taburan_Penduduk_dan_Ciri-ciri_Asas_Demografi.pdf $>$

Abu Bakar Munir "Malaysian Data Protection Law is Inadequate" (2010) $<$ http://profabm.blogspot.com. $>$. 
Department for Constitutional Affairs "A Guide to the Human Rights Act 1998: Third Edition" (2006) < http://www.justice.gov.uk/downloads/humanrights/act-studyguide.pdf $>$.

Guidelines on the Protection of Privacy and Transborder Flows of Personal Data <www.oecd.org $>$.

Information Commissioner's Office (UK). $<\underline{\text { http://www.ico.gov.uk }>}$

Lord Neuberger " Privacy in the $21^{\text {st }}$ Century" (2012)

http://www.supremecourt.gov.uk/docs/speech-121128.pdf

Pasukan Sukarelawan Malaysia or in English Malaysian People's Volunteer Corps <http://www.rela.gov.my $>$.

Prashant Iyengar "Limits to Privacy" (2011) < http://ssrn.com/abstract=1807733 >.

Report of the Committee on Super-Injunctions: Super-Injunctions, Anonymised Injunctions and Open Justice (Judiciary of England and Wales, 2011).

Shaad Saleem Faruqi "Constitutional Interpretation in a Globalised World" (2005) <www.malaysianbar.org.my>.

Source: Bureau of East Asian \& Pacific Affairs and Source: Population Distribution and Basic Demographic Characteristics 2010, Department of Statistic Malaysia, Chart 7: Percentage Distribution of the Population by the Ethnic Group, Malaysia 2010)

Source: $<$ http://www.iwgia.org/regions/asia/malaysia/877-update-2011malaysia $>$.

The Oxford Dictionaries Pro < http://english.oxforddictionaries.com/>.

The Multimedia Super Corridor (MSC) <http://www.malaysia.gov.my.>. 